University of San Diego

Digital USD

1995

\title{
Historical Case Study: San Diego and Tijuana Border Region Relationship with the San Diego Police Department, 1957-1994
}

Adolfo Gonzales EdD

University of San Diego

Follow this and additional works at: https://digital.sandiego.edu/dissertations

Part of the Leadership Studies Commons

\section{Digital USD Citation}

Gonzales, Adolfo EdD, "Historical Case Study: San Diego and Tijuana Border Region Relationship with the San Diego Police Department, 1957-1994" (1995). Dissertations. 613.

https://digital.sandiego.edu/dissertations/613

This Dissertation: Open Access is brought to you for free and open access by the Theses and Dissertations at Digital USD. It has been accepted for inclusion in Dissertations by an authorized administrator of Digital USD. For more information, please contact digital@sandiego.edu. 
HISTORICAL CASE STUDY:

SAN DIEGO AND TIJUANA BORDER REGION RELATIONSHIP WITH THE

SAN DIEGO POLICE DEPARTMENT 1957-1994

by

Adolfo Gonzales

A dissertation submitted in partial fulfillment

of the requirements for the degree of

Doctor of Education

University of San Diego

1995

Dissertation Committee:

Patricia A. Lowry, Ph. D., Chair

Ray Brandes, Ph. D.

Edward Kujawa, Ph. D. 


\begin{abstract}
HISTORICAL CASE STUDY:

SAN DIEGO AND TIJUANA BORDER REGION RELATIONSHIP WITH THE SAN

DIEGO POLICE DEPARTMENT 1957-1994
\end{abstract}

Large numbers of undocumented persons cross through the hills and canyons along the San Ysidro/Tijuana border region, on a nightly basis. As these helpless victims cross, border bandits and other criminals stalk these people and prey on them like predatory animals. The San Diego Poljce Department is charged with the responsibility of providing public safety along the United States/México international border.

The purpose of this research was to investigate the circumstances which led to the establishment of the San Diego/Tijuana international border (1846-1848), the role and policy of the San Diego Police Department along the international border, and the relationship of the Méxican law enforcement agencies with the San Diego Police Department from 1957 to 1994.

The study showed that the international border along the San Ysid:o/Tijuana border was created following the Méxican-American War of 1848. The role and responsibility of the San Diego Police Department along the San Ysidro/Tijuana international border grew from 1957 to 1994 . In 
1957, San Diego Police officers were conducting juvenile inspections at the border. In 1976, San Diego Police officers were assigned to the Border Alien Robbery Task Force, patrolling the canyons and hills along the international border disguised as illegal aliens. These officers worked as team members with agents from the U. S. Border Patrol. The working re' ionships betw'een these officers anđ Méxican law enforcement officials were limited.

As time went-on, the border task force saw different opportunities and different challenges. During the 1980s, the border task force changed their old tactics from working as disguised Méxican aliens to working in full police uniform. In 1990, the border task force began working in a partnership with the Méxican law enforcement task force known as the Beta Group. Officers from both the United States and México develope: professional working relationships with each other, improved bi-lateral United States/México relations, and reduced the number of officerinvolved shootings and reported violent crimes along the international border. 


\section{Adolfo Gonzales 1995}

\section{(C) All Rights Reserved}




\section{TABLE OF CONTENTS}

List of Illustrations

List of Tables

Acknowledgements

Chapter

I: $\quad$ Introduction $\ldots \ldots \ldots \ldots \ldots \ldots \ldots \ldots \ldots \ldots$

II Part1: Early history of San Diego, San Ysidro/Tijuana

Border, and the San Diego Police Department from

1889 to 1957

II Part 2: History of San Diego Police Department, its role and policies along the San Ysidro/Tijuana Border from 1957 to 1994 .......................... 96

III: Methodology ....................... 198

IV: Summary of the role and responsibility of the San Diego Police Department along the San Ysidro/Tijuana Border Region, 1957-1994 ................... 215

V: Conclusions/Recommendations ............ 241

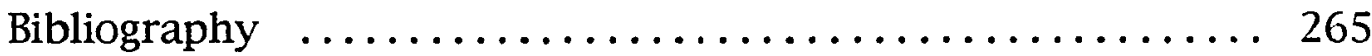

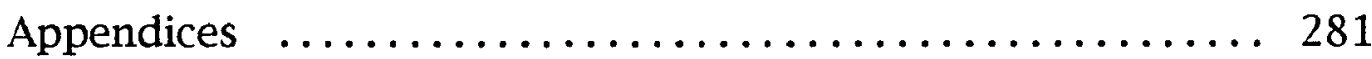

Appendix A Terminology ................... 282

Appendix B SDPD Chiefs Of Police, 1889-1994 ........ 286

Appendix $C$ Code of Ethics .................. 287

Appendix D Map of Southern Division ............ 288

Appendix E Border Task Force Teams 1977-1994 ..... 289

Appendix F Letter from Mexican Government ......... 291

Appendix $G$ Radio station license $\ldots \ldots \ldots \ldots \ldots \ldots \ldots . .292$

Appendix H National Guard letter, March 24, 1994 ... 293 


\section{LIST OF ILLUSTRATIONS}

Plate

Follows Page

I Map of Horton's Addition 35

I I Horton Plaza, Circa $1886 \quad 36$

II I Mexican Customs House, c1887 39

IV William Smythe $\quad 40$

V Map of San Diego-Tijuana Border 44

VI Tijuana tourist crossing Tijuana River 45

VII Tijuana flood of 1927

VIII View of Tijuana from border 46

IX San Diego/Tijuana Border crossing, c1918 47

X San Diego/Tijuana Border crossing, c1922 47

XI San Ysidro Port of Entry, c1925 48

XII United States and Mexico border crossing 49

XIII Map showing second border crossing $\quad 51$

XIV San Ysidro/Tijuana border, c1969 $\quad 59$

XV Cobblestone Jail, c1870 $\quad 60$

XVI Chief of Police, Joseph Coyne 62

XVII San Diego Police officers in front of Station 67

XVIII Antonio Gonzales, first Chief of Police 69

XIX Officer Jerry Martindale, dispatching 84 
XX Officer William Harrison in a "Radio" car 84

XXI Southern Division, Border check, 1960s 96

XXII Sam Edmonds, on motors 111

XXIII First Hispanic officer, José Cota 112

$\begin{array}{ll}\text { XXIV Policewomen candidates } & 116\end{array}$

XXV Connie Van Patten with other officers 123

$\begin{array}{ll}\text { XXVI Original Border team, BARF } & 126\end{array}$

XXVII Border Crime Prevention Unit, BCPU 128

XXVIII Border Crime Intervention Unit, BCIU 137

$\begin{array}{lll}\text { XXIX BCIU logo } & 146\end{array}$

XXX U.S. Border Patrol Agent Leo Calderhead 160

XXXI BCIU members talking with Mexican vendors $\quad 180$

$\begin{array}{ll}\text { XXXII Boundary marker at border } & 180\end{array}$

XXXIII Mexican nationals waiting to crossing into U.S. 180

XXXIV High intensive stadium lights at border $\quad 180$

XXXV San Diego Police Department, $1938 \quad 180$

XXXVI Crowds watching the Battle of Tijuana 180

XXXVII Border lines close at 9 p.m. $\quad 180$ 


\section{LIST OF TABLES}

Table Number

Page

1 Employment of African-Americans and Hispanics

2 Percentage of sworn SDPD officers for 1991

3 Selected violent crimes along Border, 1984-1988

4 Selected violent crimes along border, 1989-1994

5 Break down by race, sex, and age of arrest/detention of undocumented persons for 1994

$6 \quad$ Beta Group statistics for 1990-1994

7 U.S. Border Patrol apprehensions, 1958-1994

162

8 Value \& size of drug seizures by USBP, 1981-1994 162

9 Apprehensions since start of Gate Keeper, 1994

10 United States legal immigration, 1989-1992 


\section{ACKNOWLEDGEMENTS}

This last phase of the doctoral process has been an extremely laborious and challenging. I have been exceptionally fortunate to have had the moral, emotional and professional support of many people--to all of whom I am expressly greatful. A particular thanks to Dr. Patricia Lowry, my committee chairperson, for her guidance, constructive criticism, and scholarly advise throughout these long months. A special thanks to Dr. Ray Brandes, another committee member, for his patience and scholarly support, and a sincere thanks to Dr. Edward Kajuawa, another committee member, for his encouragement and guidance. I consider it a privilege to have had such distinguished and professional scholars on my committee.

A special thanks to the San Diego Police Department, its chief, Jerry Sanders, and all its officers, at all ranks, for their cooperation and assistance with this research project.

Most of all, I wish to express my love and appreciation to my wife, Rosalia. Her unselfish support and encouragement these last few months was probably the only reason our marriage survived the trauma of a doctoral dissertation. A special thanks and love to my daughters, Melody and Christine, for their understanding during these last few months of my dissertation process. 


\section{CHAPTER I}

INTRODUCTION

\section{Statement of the Issue}

Researchers have traced the history of San Diego, Tijuana, and the San Diego Police Department from various periods. 1 Yet, the role of the San Diego Police Department at the international border has been overlooked. This case study focused on the San Diego Police Department and its relationship with México law enforcement agencies along the Tijuana/San Diego international border from 1957 to 1994. An historical review of the San Diego/Tijuana region was conducted in order to better understand the dynamics of the San Diego/Tijuana border area.

\section{Statement of the Problem}

Large numbers of undocumented persons cross through the hills and canyons along the 14 mile stretch of the San Ysidro/Tijuana border, on a nightly basis. As these helpless victims cross, border bandits and other criminals stalk and prey on these people like predatory animals. 2 The United States Border Patrol and 
Immigration and Naturalization Service (INS) have been unable to prevent border violence. The U.S. Border Patrol is primarily responsible for controlling the flow of illegal immigration, not for preventing violence along the border. 3 The San Diego Police Department is charged with the responsibility of providing public safety along the United States/México international border at San Ysidro, California. This area is bordered on the west by the City of Imperial Beach and on the east by the San Diego County line. Purpose of the Study

The purpose of this research was to investigate the circumstances which led to the establishment of the San Diego/Tijuana international border (1846-1848) and the reasons why the border was created at its current location. In addition, the researcher examined the role of the San Diego Police Department along the international border from 1957 to 1994.

\section{Research Questions}

Every dissertation should have a thesis-a reason for the research. This historical case study investigated the following: - When and how was the United States/México international border established at the San Diego/Tijuana border region? 
- What was the role of the San Diego Police Department at the international border from 1957 to 1994 ?

Significance of the Study

This study provided vital information to the law enforcement community and added to the general body of literature regarding the San Diego/Tijuana border region for general research purposes for the community at large.

\section{Early History}

The County of San Diego was first settled by the Kumeyaay tribes, some 25,000 years ago. The Kumeyaay were a migratory people, moving with the seasons. In the summer these native people would stay near the coast to catch birds and fish of the marshes or to gather shellfish along the shore. They also would move into the Cuyamaca Mountains to hunt for deer and rabbits. In the winter, the Kumeyaay would discontinue their hunting and settle into permanent villages. As time went on, the Kumeyaay people disappeared. It is unknown what happened to the Kumeyaay tribe, but it has been suggested that they migrated south to become the primitive tribes of Baja California reported by the Spanish missionaries. 4 
In September 1542, this region was visited by Europeans, led by Juan Rodríguez Cabrillo. On November 10, 1602, the second wave of Spanish explorers, led by Don Sebastian Viscaíno, mapped the same harbor once discovered by Cabrillo and named the bay after the Franciscan Monk, San Diego de Alcalá.

In 1769, Father Junípero Serra and Gaspar de Portolá founded the first presidio and La Mision de San Diego de Alcalá. The site of Old Town, founded in 1821 , was by no means favorable for a seaport town. The presidio was located on the hill above the Mission Valley River, because it could be fortified and defended against the native inhabitants.

Andrew B. Gray, a major-general in the Confederate Army, was the first person to select the present site of San Diego. Gray's attempts to build a new town on the area that is now Market Street, failed primarily because of the lack of drinking water. Although, the new town had a wharf and government buildings, it could not compete with the old town. 5

The population in San Diego was reported at 350 residents in 1810 ; by 1820 , it had increased to 450 ; and by 1830 , the population had increased to 520.6 
On November 21, 1828, the Méxican government passed a law permitting the acquisition of land by people occupying it. In the early 1800 's, José María de Echeandia (1825-1831) secured the rights and land from federal authorities to settle and operate a ranchero in northwestern Baja California. During the early years of Méxican rule, Governor José María Echeandia moved the capital from Monterey to San Diego. During this period, San Diego became the capital for both the Alta and Baja California.

Santiago Argüello received title to the Ranchero de Tijuana in 1829. By 1840 Ranchero de Tijuana was the largest of six cattle ranches in the area that collectively were considered a town.7

The name "Tijuana" has several definitions. Cardenas (1955) stated that a picturesque woman named Juana came from Sonora as a cook and people referred to the area by her name-Tia Juana, literally "Aunt Jane."8 The name "Tijuana" may have derived from an Indian language originating in Baja California Sur.9 The area on both sides of the border was once called Tijuana. To distinguish between the two Tijuanas, the town on the Méxican side of the border was called Old Town in the early 1900 s. In the 1920 s, the Tijuana on the United States side of the border was called San Ysidro. 
Also, people in the United States tended to pronounce the " $a$ " of Tia and spell Tia Juana in two words while in México the name was pronounced Tijuana and spelled as one word. Some Méxicans thought the name of Tijuana was a degrading name to have for a town. Thus, in 1925 the Méxican Congress changed the name of the town to Ciudad Zaragosa, but this change was met with opposition. In 1929, Méxican President Emilio Portes Gil changed the name of the town back to Tijuana.10

On September 20,1834, San Diego de Alcalá mission was put into the hands of government commissioner Juan José Rocha. Méxican governor Pio Pico awarded the mission lands to a retired soldier and former alcalde (mayor) of San Diego named Santiago Arguëllo.11

On January 1,1835 , Juan Osuna was elected as the first alcalde, a combination "mayor" and Juez de paz, of San Diego. San Diego had become a town with a Méxican population of over 400 residents. 12

When the United States annexed Texas in 1845 and began to move troops into the area, México responded by bringing troops across the Rio Bravo (Rio Grande) to protect its territory. Although conflict between the United States and México existed before the 
Méxican-American War, San Diego seemed relatively unaffected by the conflict. On May 13, 1846, war was declared by the United States and justified with the accusation that México was the aggressor. Two years later, on March 10,1848, the Méxican-American War came to an end with the signing of the Treaty of Guadalupe Hidalgo. The terms of the Treaty had México giving up Texas and California, land which represented more than one-half of the Republic of México. México was to receive $\$ 50$ million dollars and have their debt of $\$ 2$ million dollars canceled by the United States. In addition, the Méxican population remaining in the region was given United States citizenship.13 The final draft of the Treaty read, in part:

And, in order to preclude all difficulty in tracing upon the ground the limit separating Upper from Lower California, it is agreed that the said limit shall consist of a straight line drawn from the middle of the Rio Gila, where it unites with the Colorado, to a point on the coast of the Pacific Ocean distant one marine league due south of the southernmost point of the port of San Diego, according to the plan of said port made in the year 1782 by Don Juan Pantoja, second sailing master of the Spanish fleet, and published at Madrid in the year 1802. . . 14

Following the signing of the Treaty of Guadalupe Hidalgo, negotiations over the location of the United States-México border ranged from leaving California in México to giving Baja California to 
the United States. México said that Baja California was poor in natural resources and of no importance to the United States. México needed Baja California for the strategic defense of its Republic, and it also needed a land communications route between Baja California and the Méxican mainland. The resulting line cut diagonally across the Tijuana River Valley, leaving the mouth of the valley on the United States side and the narrowing upper part of the valley on the Méxican side. Thus the San Diego-Tijuana international border was established. This line made Tijuana the most distant point within the Republic of México from the national capital, 1,845 miles.15

The San Ysidro-Tijuana Port of Entry is presently located six miles east from the Pacific Ocean, on the northern edge of the Tia Juana River Valley, and on the southwest facing slope of the Otay Mesa about 75 feet above sea level.16 In 1957, the City of San Diego annexed the San Ysidro community, including Palm City, Nestor, and Otay Mesa. This annexation brought San Diego's city limits up to the international border. 17

\section{San Diego Police Department}

The City of San Diego was incorporated in 1888 and established its police department on May 16, 1889.18 Joseph Coyne (1889-1891) 
was the first chief of police. Prior to being appointed as Chief of Police, Joseph Coyne served as the San Diego County Sheriff from 1876 to 1882.19 Before 1889 , the City had deputy city marshals providing the law enforcement and police service. In addition, the City of San Diego expanded from 12 square miles to 78 square miles. This expansion added Coronado, North Island, and all of the bay areas to the City's boundaries. 20 The freeholder's charter granted the City of San Diego the peninsula (Coronado, in 1889), and the law required that two years must elapse before the charter could be amended. The segregation bill that Major Levi Chase was trying to push through the State legislature would be of no effect, even if passed.21 This petition for segregation bore the names of more residents of San Diego than there were residents of Coronado Beach. This apparently justified the court in finally brushing all contrary considerations aside and simply ruling that the will of the people had been sufficiently shown--and Coronado thus won its freedom. In 1890, Coronado Beach incorporated as a city. 22

In the 1880 s San Diego was a wide-open town with gambling, liquor, and prostitution which had flourished, in Stingaree Town. The infamous Stingaree was located south of Market Street, then called 
"H" Street. The Chief of Police during this time was William $\mathrm{H}$. Crawford, who held the Office for only three months. It was reported that officers were quick to shoot and use excessive force, which was Chief Crawford's downfall. Between 1890 to 1957, the Police Department saw 24 chiefs of police and many changes within the organization. Yet, the City was not providing services to the community of San Ysidro because it had not incorporated it.

On October 16, 1947, Adam Elmer Jansen was appointed Chief of Police. He named Wesley Sharp as his second in command. Chief Jansen made it clear that past abuse and dishonesty would not be tolerated. Jansen moved the police department toward professionalism. Chief Jansen created a modern, comprehensive manual of operations, and updated the rules and operations of the department. 23

Chief Jansen served as Chief from October 16, 1947 to January 7, 1962. During his tenure, Chief Jansen accomplished a number of goals for the police department; the police school became an academy in 1949; in 1950, Chief Jansen created the San Diego Police Reserve program; on July 1, 1954, he appointed four policewomen, the first since the mid-1920s; and he established a border substation at San 
Ysidro and a police checkpoint at the San Ysidro/Tijuana border gate. This program served to screen juveniles going into México and turn back those juveniles who were unescorted by an adult. In addition, Chief Jansen improved the liaison efforts with Tijuana, México law enforcement agencies.24

Late in 1962, a new police substation was built in San Ysidro, for Southern Division personnel, at 663 Tijuana Boulevard, close to the international border. Southern Division was created in 1958 when San Diego annexed twenty-two square miles along the international border, creating South San Diego. The station provided space for one hundred officers and had a complete service garage. 25

On February 13, 1976, Bill Kolender was confirmed as the 29th Chief of Police for the City of San Diego. This was the first public confirmation hearing in the history of the City of San Diego. Chief Kolender was forty years old when he was first appointed acting Chief, after Chief Ray Hoobler resigned on September 9, 1975.26

Chief Kolender quickly established a border task force headed by lieutenant Dick Snider. The purpose of this task force was to provide public safaty along the United States and México border within the City limits. This team of officers provided protection, to 
any person within the Tijuana-San Diego border region, against border bandits committing attacks, rapes, robberies, and murders on unsuspecting victims. The Border Alien Robbery Force (BARF), as the task force was known, was created in 1976 but was abolished two years later. During the tenure of the BARF unit, members were involved in seven officer involved-shooting which resulted in the wounding of three BARF members and with the wounding of seven Méxican Nationals. 27

Because of the extreme border violence, the BARF task force was suspended in 1978. However, a similar task force was reinstated in January 1984, operating under a different philosophy and working with U.S. Border Patrol Agents.28 The combined task force disrupted the bandits' lucrative business and compiled impressive statistics. In contrast to the previous San Diego Police Border Crime Task Force-BARF, the combined unit took a high profile position by working in uniform and prominently displaying their badges. 29

On September 19, 1988, Robert W. Burgreen was appointed Chief of Police after serving two months as acting Chief of Police.30 Chief Burgreen continued supporting the Border Crime Prevention 
Unit (BCPU) and the México Liaison Unit.31

In 1991, Jerry Sanders was appointed as the 30th Chief of Police. Chief Sanders was well liked by the rank-in-file and the command staff of the police department as well. Under the administration of Chief Sanders, the border crime task force underwent some changes. The name of the border crime task force was changed from the Border Crime Prevention Unit to the Border Crime Intervention Unit (BCIU). In addition, the methods of operations changed from simply working with the United States Border Patrol to collaborating with the Méxican law enforcement task force called "Grupo Beta" (Beta Group).

In the early 1990s, Méxican federal authorities identified three dimensions of violence along the international border: actions committed by Méxicans against Méxicans in México; acts of violence against Méxicans-mostly undocumented migrants-on the United States side of the border by non-governmental suspects; and "institutional violence" committed on the part of the United States authorities against Méxican citizens, again mostly undocumented migrants. As a result of this, the Méxican government created a task force called "Grupo Beta." This task force consisted of thirty police 
officers chosen from local, state, and federal agencies, placed directly under the direction of the Méxican Undersecretary of the Interior, Miguel Limón. The Beta Group was tasked with fighting criminal delinquency on the Méxican side of the border involving border violence. 32

This study was conducted within a large metropolitan police department in Southern California. This police organization was selected because of its close proximity to the San Diego/Tijuana international border. A further consideration was that the researcher was a veteran officer of said police department and was able to access what was an often "closed world" to external police academicians. 


\title{
CHAPTER ONE
}

\author{
ENDNOTES
}

1. For the history of San Diego and Tijuana see Lawrence A. Herzog. Where North meets South: Cities, space, and politics on the U. S.-Mexico border. Austin, TX: University of Texas Press. (1990). For the history of the San Diego Police Department see Pliny Castanien. To protect and serve: 1889-1989. San Diego Historical Society: San Diego, CA. (1993).

2. The following authors talked about border crimes and illegal aliens: Lawrence Herzog, Where the North meets the South. 1990; Abraham Lowenthal \& Katrina Burgess, The California - México connection. 1993; Oscar Martinez, Border people: Life and society in the U. S. - México borderlands. 1994; and Daniel Wolf, Undocumented aliens and crime: The case of San Diego County. 1988.

3. Daniel Wolf. Undocumented aliens and crimes: The case of San Diego County. San Diego, CA: University of California at San Diego. (1988).

4. San Diego County United Way, Latino Future Scan, 1990, pp. 2-12. Various community leaders came together to forecast the latino future in San Diego County.

5. William E. Smythe. History of San Diego 1542-1908: An account of the rise and progress of the pioneer settlement on the Pacific coast of the United States. Vol. I. "Old Town." The History Company, 1908, pp. 316-322.

William Smythe also wrote: "The Conquest of Arid America," "Constructive democracy, the economics of a square deal," and a two volume "History of San Diego," as follows: William E. Smythe. History of San Diego 1542-1908: An account of the rise and progress of the pioneer settlement on the Pacific coast of the United States. Vol. I. "Old Town." The History Company, 1908; and William E. Smythe. History of San Diego 1542-1908: An account of the rise and progress of the pioneer settlement on the Pacific coast of the United States. Vol. II. "The modern city." The History Company, 1908.

6. Latino Future Scan, op. cit., 12.

7. John A. Price. A History of Tijuana: Border Town and Port-of-trade. October, 1968. A paper prepared for San Diego State University.

8. C. A. Cardenas. Tijuana, Ensayo Monigrafico. Editorial style, México, D.F. 1955.

9. T. D. Proffitt, Tijuana: The history of a Méxican metropolis. San Diego State University Press: CA. 1994, p. 37. 
10. Price, op. cit., 2.

11. Michacl McKeever, 1985, pp. 29-37.

12. Ibid., 48.

13. Latino Future Scan., op. cit., 12-13.

14. Treaty of Guadalupe Hidalgo, Article V, as found in Peter Thomas Conmy, $A$ Centennial Evaluation of the Treaty of Guadalupe Hidalgo, 1848-1948. (Oakland: Public Library, 1948), p. 28.

The Treaty of Guadalupe Hidalgo established the official border in 1848 . The agreement between the United States and México cut a straight line between USA and México territory from the point where the Gila and Colorado River meet the Pacific Ocean one marine league south of San Diego. In 1851, a joint Boundary Commission made of teams from both countries set up a monument which still stands at the Border Field State Park. This marks the south-western most point of the United States.

15. Price, op. cit., 3.

16. Kenneth Martis C. (1970). "United States International Land Border crossing: San Ysidro, California." A Thesis for Master of Arts in Geography for San Diego State College, 19.

17. Ibid., 20.

18. Elizabeth C. MacPhail. The story of new San Diego and of its founder Alonzo E. Horton. 1969. p. 97.

19. Pliny Castanien. To protect and serve: A history of the San Diego Police Department and its chiefs, 1889-1989. San Diego Historical Society, San Diego,CA. 1993, pp. 48.

Pliny served as police reporter for the San Diego Union for almost twenty-six years. He complied papers relating to the San Diego Police Department from 1948-1989. Castanien collected records from the Records Bureau of the San Diego Police Department.

\section{Ibid., 8.}

21. Major Levi Chase was a prominent resident of San Diego during the $1880 \mathrm{~s}$. Major Chase was a native of Maine and a veteran of the Civil War. In 1868, Major Chase practice law in San Diego and daily was connected with much of the important litigation arising in San Diego County. Levi Chase died on May 31,1906 . At the time of his death, he was the oldest member of the San Diego Bar Association. 
Clarence Alan McGrew. (1922). City of San Diego and San Diego County: The birthplace of California. Volume I, The American Historical Society: Chicago and New York. 115-116.

22. Herbert Hensley. The Memoirs of Herbert Hensley:The History of San Diego, City, County, and region through the memories, anecdotes and recollections of Herbert Hensley. Collected and edited by Hensley over a three year period, 1949-1952. Vols. I-V. Deposited in the Archives of the San Diego Historical Society, October 6, 1952. Vol. IV. pp. 523-538.

23. Castanien, op. cit., 77-79.

24. Ibid., 79-80.

25. Ibid., 83.

26. Ibid., 98.

27. Joseph Wambaugh. Lines and Shadows. New York, 1984. Joséph spent fourteen years with the Los Angeles Police Department and is the author of eleven bestsellers: The New Centurions, Lines and Shadows, The Blue Knight, The Onion Field, The Choirboys, The Black Marble, The Glitter Dome, The Delta Star, The Secrets of Harry Bright, Echoes in the Darkness, and The Blooding.

28. Ibid., 101.

29. Denny Fallon. The National Centurion: A police lifestyle magazine. Volume II, number VII. Battle at the Border. August 1984. pp. 24, 36-37, 39, 54. In contrast to the previous San Diego Police Department Border Crime Task Force (BARF), glamorized in Joseph Wambaugh's book, Lines and Shadows, the combined unit now takes a high profile.

30. Castanien, op. cit., 107.

31. Two San Diego Police officers work in México as liaison to the San Diego Police Department (SDPD) and other United States law enforcement agencies. These officers work out of the Criminal Intelligence Unit of the SDPD. Later, under Chief Sanders, this team increased in size by the addition of a sergeant. These officers are bilingual in Spanish and English.

32. Abraham F. Lowenthal, \& Katrina Burgess. (Eds.). The California México connection. Stanford, CA: Stanford University Press. 1993, p. 349. In the early 1990s, the Méxican federal authorities identified three dimensions of violence along the international border: actions committed by Méxicans against Méxicans in México; acts of violence against Méxicans-mostly undocumented Méxican nationals migrants-on the United States side of the border by nongovernmental suspects; and "institutional violence" on the part of the United 
States authorities against Méxican citizens, again mostly undocumented migrants. As a result of this, the Méxican government created the "Grupo Beta." The task force consisted of thirty police officers chosen from local, state, and federal agencies, placed directly under the Méxican undersecretary of the interior, Miguel Limón, and charged with the fight against delinquents on the Méxican side of the border involved in border violence. 


\section{CHAPTER II}

PART 1

EARLY HISTORY OF SAN DIEGO, SAN YSIDRO/TIJUANA BORDER, AND THE SAN DIEGO POLICE DEPARTMENT FROM 1889 TO 1957

Within this chapter, the following subjects were discussed: Prehistory, Spanish Era-Proto history, early history, history of San Diego, San Ysidro, Tijuana, San Ysidro/Tijuana Port of Entry, and the San Diego Police Department from 1889-1957. Prehistory 9,500 B. P. $-1,000$ A. D.

It is appropriate to discuss the prehistoric and historic periods as they relate to the regional Indian cultures as described in the record and reported in a number of studies. Some of the earliest records are reported in the form of notes or memoranda at the Museum of Man, the work of the regional pioneer archaeologist Malcolm J. Rogers.1

Rogers established a sequencing system for identification of assemblages and stratigraphy, such as his report of 1966. Later, several academicians provided their interpretations of the regional 
prehistoric record. Those professors were Dr. True in 1958, 1960, and 1966, Warren in 1964 and 1966, and Moriarty in 1966 and 1967.2

In brief the reports identify the "San Dieguito Complex" as a distinct group of people who occupied sites in the San Diego region 10,000 to 8,000 years B. P., and are, however, considered as being of a mobile, hunting and gathering society.

The La Jolla Complex dated about 9,000 to 8,500 B. P., resided primarily along the coast. This culture is best recognized for its shell middens and grinding tools closely associated with the marine resources of the area. A range of lithic manufacturing techniques are often found at their sites. Forest Shumway, Carl Hubbs and James R. Moriarty (1961)3 and Brian Smith and Moriarty (1985) 4 reported on this branch of the complex. Brian Smith in 1966 suggested that there were several complexes including the inland sites which contained milling tools and food bone, lacked marine-related food refuse which he suggested may relate to a seasonal migration from the coast to the inland valleys.

The Kumeyaay Indians resided as a Yuman-language group which moved from the Colorado River area to the western area of 
San Diego County beginning about 2,000 years ago. Sites in many parts of San Diego County date variously since that period. The Kumeyaay Indians were a seasonal hunting and gathering people, with cultural implements and diet different from the La Jolla complex. Perhaps more advanced than the La Jolla complex, they used bows and arrows, and harvested the acorn as a primary food staple. Marine flora and fauna resources were collected from both the sea and fresh water ecozones. Sources for the definition of the Kumeyaay may be found in Smith and Moriarty (1993), Carrico and Taylor (1983), and Moratto (1984) and numerous other reports.5

In the larger San Diego urban area the prehistoric, protohistoric and historic record have been reported in several studies. The Museum of Man files and archaeological sites began for San Diego County region and continued through the 1930 s assisted by Dr. George Carter.6

Early Man sites have been found in various parts of the county from Oceanside to San Ysidro. Richard Carrico (1984)7 suggested the following prehistoric eras based on a compilation of reports he reviewed and cited: 
Cultural Setting

San Dieguito Complex

Harris Site (SDi-149)

La Jolla Complex

Los Compadres (W-1578)
Time

9,500 B. P.

8,000 B. P.

7,500

B. P.

6,000 B. P.

La Jolla Complex termination 3,000 B. P.

Late Prehistoric cultures $\quad 1,000$ A. D.

Late Milling

Carrico (1984) described the Proto-Historic period as follows:

Spanish Era Proto-Historic 1541 A. D.

Hispanic Era

1769 A. D.

Méxican period

1821 A. D.

American period

1848 A. D.

During the Historic Period, Indians lived within or on the fringes of San Diego in rancherias at times. A study of "Urban Indians in San Diego," by Susan Carrico (1983), determined that there were few small areas of concentration within San Diego, and that most assimilated as long as they were in small numbers. They appeared to have functioned as those of other ethnic group maintaining their own traits and their own trades that worked best for them. 8 
A lack of compliance with such laws as the Dawes Act and the lack of tolerance for Indians "camped" within the City, forced the City Trustees to move the Indians further out. Some of the Indians attempted to dissolve their relationships with specific tribes so as to obtain permanent ownership of lands, however, only a few cases prevailed on their behalf.

There were in essence no real reservations within San Diego County. Rancherias, however, existed in Switzer Canyon, Coyas Drainage San Diego, and around the area of 22nd Street and Logan Avenue. None were permanent, however and from photographs on file at the San Diego Historical Society in Balboa Park, the housing could best be described as made from bush materials covered with tarps.

As San Diego grew, Indians moved further east and south of San Diego, especially abandoning their coastal villages. By the year 1900 no rancherias remained in San Diego, even within the Middletown or New Town areas. Development moved forward, so the Indians retreated to reservations or moved south into the area of Lower California.

In a special study for the Butler/Roach Group and the City of 
San Diego (Brandes, 1994),9 reviewed and documented on a map a confidential report which reflected all of the archaeological sites previously reported in the Tijuana River Valley. That region, particularly along and around the International Boundary line, is filled with prehistoric sites.

Such reports and locations remain confidential to the general public and are not accessible, however, the sites are known to be undisturbed and of such quantity that disturbance for the purpose of growth projects has been drastically inhibited.

Spanish Era-Proto historic: $1541-1867$

Before 1542, the Spaniards had already made numerous TransPacific crossings and returns to México via the Japanese currents, trading in the Philippines and Japan with the use of the Manila Galleons. Under the laws of Spain, on return trips the vessels were not allowed to stop at any port, nor were men allowed to go ashore for any purpose.10 Before long explorers were examining coastal shores along California, such as when Juan Rodríguez Cabrillo sailed into the San Diego harbor, in September 1542.11 The Spanish Crown had earlier claimed much of the New World and even the Pacific Islands as Nueva España under the laws understood by all nations of 
the world at this time. If the waters moved by the vessels of a nation touched the shores, then those lands belonged to that nation.

The second expedition of Spanish vessels was under the Captainship of Don Sebastian Vizcaíno, who mapped the same harbor once discovered by Cabrillo.12 Vizcaíno named the bay after the Franciscan Friar, San Diego de Alcalá.13

In 1769, Father Junípero Serra and Gaspar de Portolá led three expeditions by sea from San Blas and two expeditions by land from La Paz and Loreto, and celebrated the founding of San Diego on July 16, 1769. Father Serra wrote:

[1] noted the day as a very memorable one because five centuries earlier under the same diurnal sign, Spanish forces had defeated the Mohammedans at Las Nava de Tolsa.14

During the next few months, the Spaniards struggled to exist at this site, and other arms of the expedition marched and sailed north to San Francisco and Monterey. Within a short time, the construction was begun of a small chapel within the presidio, The Royal Presidio of San Diego.

Problems between the Indians at the village of Cosoy, either already on the hill or in Mission Valley, brought Father Serra to 
request permission, which was granted to him, to bring founding Mission San Diego de Alcalá six miles east and up Mission Valley near the river of that name. 15

The movement for independence from Spain by the people of México began as early as 1786 , but it did not reach seriousness until El Grito de Dolores in Chihuahua, México, in 1810 by Fray Hidalgo del Castillo.

The government in Alta California was poor and transient, as governors and military leaders alternated regularly. The first city in California, at the presidio, was inhabited by about 350 settlers, many of whom overused the environment and the landscape. The abuse of the environment and the landscape required the Spaniards, before 1821 , to move down the southern slope to the south and from "Old Town" to what is today known as the Old Town State Historical Park. That area, from the date of the Independence Movement, in 1821, and the end of the Méxican War in 1848, was governed by Méxican officials. Following the independence of México from Spain, the Méxican government issued vast land grants in order to exploit its northern domains.

During the early years of Méxican Rule, Governor José M. 
Echeandia (1825-1831) moved the capital from Monterey to San Diego. On November 21, 1828, the Méxican government passed a law permitting the acquisition of land by people occupying it. In the early 1800's, José M. Echeandia secured the rights and land from federal authorities to settle and operate a ranchero in northwestern Baja California. Santiago Argüello received title to the Ranchero de Tijuana in 1829. By 1840 Ranchero de Tijuana was the largest of six cattle ranches in the area that collectively were considered a town.16 The name "Tijuana" had several definitions. Cardenas (1955) stated that a picturesque woman named Juana came from Sonora as a cook and people referred to the area by her name-Tia Juana, literally "Aunt Jane." 17 The name "Tijuana" may have derived from an Indian language originating in Baja California Sur.18 The area on both sides of the border was once called Tijuana. To distinguish between the two Tijuanas, the town on the Méxican side of the border was called Old Town in the early 1900s. In the 1920s, the Tijuana on the United States side of the borer was called San Ysidro. Also, people in the United States tended to pronounce the "a" of Tia and spell Tia Juana in two words while in México the name was pronounced Tijuana and spelled as one word. Some Méxicans 
thought the name of Tijuana was a degrading name to have for a town. In 1925, the Méxican Congress renamed the town of Tijuana to Ciudad Zaragosa, but this change was met with opposition. In 1929, México's President Emilio Portes Gil, changed the name of the town back to Tijuana. 19

In 1834, San Diego's population reached slightly over 500 residents. At that point, San Diego had sufficient population to warrant San Diego receiving the status as a "town," eligible for elections and local rule. An ayuntamiento, alcalde, juez de paz, and other leaders governed until the United States government took charge in 1848.20

On September 20,1834, San Diego's mission was put into the hands of government Commissioner Juan José Rocha. Méxican Governor Pio Pico awarded the mission lands to a retired soldier and former alcalde (mayor) of San Diego named Santiago Argüello.

On January 1,1835 , Juan Osuna was elected as the first alcalde, a combination mayor and justice of the peace, of San Diego.

Old Town did not flourish, but was the center of business and social activity in the San Diego region from 1821 to 1872 , until a disastrous fire virtually destroyed the town. This area was also a 
place where ranchers and traders did business.

During and after the Méxican War, the United States Army came to San Diego; some were stationed at the now ruins of Mission San Diego de Alcalá, while others were at Point Loma. Although conflict between the United States and México had existed before the Méxican-American War, San Diego was relatively unaffected by the conflict. Only the Battle of San Pasqual, near Escondido, stood out as a piece of the military history. When the United States annexed Texas in 1845, and began to move troops into that area, México responded by bringing Méxican troops across the Rio Bravo (Rio Grande) to protect its territory. On May 13, 1846, the United States declared war against México, justifying it with the accusation that México had been the aggressor.

In May 1846, Santiago Argüello lost the title to his Rancho de Tijuana to California's civil governor. In March 1857, additional registration was required for land rights. Argüello re-registered the ranch under his own name. That title was subsequently confirmed by México's President Juarez in September, 1862. On the United States side of the border Argüello contested the U. S. government's claims to his lands in the Otay and Tijuana River Valleys, again losing 
to settlers. Argüello's claims to the mission lands east into the El Cajon Valley, were upheld by the United States government in 1876.21

In 1848 , the Méxican-American War came to an end with the signing of the Treaty of Guadalupe Hidalgo. The terms of the Treaty had México giving up more than one-half of its Republic. México was to receive $\$ 50$ million dollars and have its debt of $\$ 2$ million dollars canceled by the United States. Furthermore, the Méxican population remaining in the new region were given United States citizenship. In Old Town San Diego, many Méxican families remained, now governed under the laws set down by the United States Government. Those who desired to return to México could have done so, but those who remained had to become U.S. citizens. Méxicans who were living on properties they once owned, were now required to offer such proof in American courts. The final draft of the Treaty read, in part:

And, in order to preclude all difficulty in tracing upon the ground the limit separating Upper from Lower California, it is agreed that said limit shall consist of a straight line drawn from the middle of the Rio Gila, where it unites with the Colorado, to a point on the coast of the Pacific Ocean distant one marine league due south of the southernmost point of the port of San Diego, according to the plan of said port made in the year 1782 by Don Juan Pantoja, second sailing master of the Spanish fleet, and 
published at Madrid in the year 1802...22

Following the signing of the Treaty of Guadalupe Hidalgo, negotiations over the location of the United States-México border ranged from leaving California in México to giving Baja California to the United States. México said that Baja California was poor in natural resources and of no importance to the United States. México needed Baja California for the strategic defense of its Republic. In addition, México needed a land communication route between Baja California and the Méxican mainland. The resulting line cut diagonally across the Tijuana River Valley, leaving the mouth of the valley on the United States side and the narrowing upper part of the valley on the Méxican side. This move made Tijuana the most distant point within the Republic of México from the national capital, 1,845 miles. Thus the San Diego-Tijuana international border was established.23

The Méxican government became aware of the need to establish colonies on or near the United States and Méxican border in order to thwart a "new invasion" of these isolated lands. The first settlement in northern Baja California was undertaken as part of the colonization effort directed at the border line adjacent to the United 
States. 24

As established by the Treaty of 1848 and later by the Gadsden Purchase of 1853, the international boundary between the United States and México extended over 1,952 miles (3,141 km), and exclusive of the maritime boundaries. The boundary followed the middle of the Rio Grande from its mouth on the Gulf of México a distance of 1,254 miles to a point just upstream of El Paso, Texas, and Ciudad Juarez, Chihuahua: it then followed an alignment westward overland and marked by monuments a distance of 533 miles to the Colorado River. Then it followed the middle of that river northward a distance of 24 miles and it again followed an alignment westward overland and marked by monuments a distance of 141 miles to the Pacific Ocean.25

The Chula Vista Star News reported that a Border marker was recovered north of the San Ysidro/Tijuana border by an agricultural worker in late March 1979. It was believed that the marker was the victim of the 1895 flood which pushed the marker from its original location. According to information provided by the San Diego Historical Society, the marker was only one of the 258 which dot the 1,952 miles of United States and México border. The marker 
consisted of three parts, but only the inscribed, middle portion was found. The marker weighed an estimated two tons, was 44 inches high and tapered from a four-side 40 -inch base to a 32-inch top.26 The San Diego Historical Society reported that the monument was no longer in its original position. The Méxican newspaper, "트 Heraldo," reported that the location where the marker was found was the acutal border, thus placing San Ysidro in México.27

The marker, which was labeled with the number 255 and said to mark the border established by the treaties of 1853,1882 , and 1889 , was washed away into the Tijuana river during a flood.28

In Old Town, the City of San Diego was incorporated in March 1850, and had its first "American" election on June 16, 1850. Joshua H. Bean was elected as the first mayor of the American San Diego.

In 1850, a group of individuals, including a number of United States Army officers, acquired property in the vicinity of the area that today is bounded by Pacific Highway and India Streets, between "A" and Market Streets. Here, such men as Major Samuel Peter Heintzelman, second lieutenant Thomas D. Johns, Andrew B. Gray, former chief surveyor for the American Boundary Survey Commission, José Antonio Aguirre, William C. Ferrel, and Miguel de 
Pedrorena bought this section of land, which they chose to call "New Town."

Their choice of location was a poor one. The area consisted of a few homes built by citizens, a few built by soldiers, military barracks, several saloons, and other structures built on land which remained vacant. A wharf was built with the idea that a government warehouse would be built to house materials brought by ships from the east and the northwest coast.29 By the time of the American Civil War, New Town had failed and most of the structures were either plundered for their materials or destroyed by the elements. 30

During the American Civil War, San Diego was virtually an isolated frontier settlement. For the most part the U. S. Army had vacated the region; in February 1861, Officers in the Union Army were allowed to resign from the Army, leave their arms and travel eastward if that was their desire--to join the Confederacy.

In 1862, President Abraham Lincoln returned ownership of the California missions, including Mission San Diego de Alcalá, the surrounding 22 acres and the buildings, to the Catholic Church. 31 There was essentially a historical gap in San Diego's history after 1861 because there were no newspapers in the community until 
1870.

Early history: $1867-1910$

On April 15, 1867, however, Alonzo E. Horton arrived in San Diego; his arrival changed the face of San Diego history. Alonzo was prepared to bring a city to life, and brought his money with him. He met with the Board of Trustees [City Council] and purchased 960 acres of what is now downtown San Diego for $\$ 27.50$ cents an acre.

Alonzo advertised widely, gave lots to people who would develop their holdings, offered free quarter lots to those who promised to build houses, and donated land to churches.

The first Horton addition was a one-story building, on 6th street just below “J” street, number 357. This was used as Horton's office. In 1869, Horton built a post office on 5 th Avenue below "F" Street.32

In 1870 , the population of San Diego grew to 2,300 residents; the County's population was about 4,300 . By 1870 , there were ten stores in new San Diego. In May of that year, the Horton Hall was opened and used as a theater. 33

The City was known as "South San Diego" for many years. The change to simply San Diego was made when John G. Capron went to 
I. Map of Horton's Addition in New San Diego. San Diego Historical Society, Photograph Collection. 
Washington and saw the assistant postmaster-general, and the manager of the express company in New York, and had the name changed. At the same time, Capron also had the name "Old San Diego" changed to "North San Diego."34

The seat of local government essentially moved to downtown San Diego in 1872, at the same time that John G. Capron had successfully argued for a change in the name of Old San Diego or Old Town to North San Diego.35

In the period of U.S. government control, in 1850 , there were elections held in the Old Town area where a Board of Trustees (City Council), a Sheriff, a Justice of the Peace, and other local City officials were elected or appointed to office. Early records, in both Spanish and English, indicate a number of instances of homicides, shootings, and other disturbances both in the City and in the County of San Diego.36

Even before the American period, in the California State papers, in Spanish, there are documented cases of homicides related to Indians in the County, of robberies carried off by soldiers, of mistreatment of wives by their husbands, with such details as fines, penalties, and sentencing. 37 
II. Horton Plaza in the center and Horton house, Circa 1886. San Diego Historical Society, Photograph Collection. 


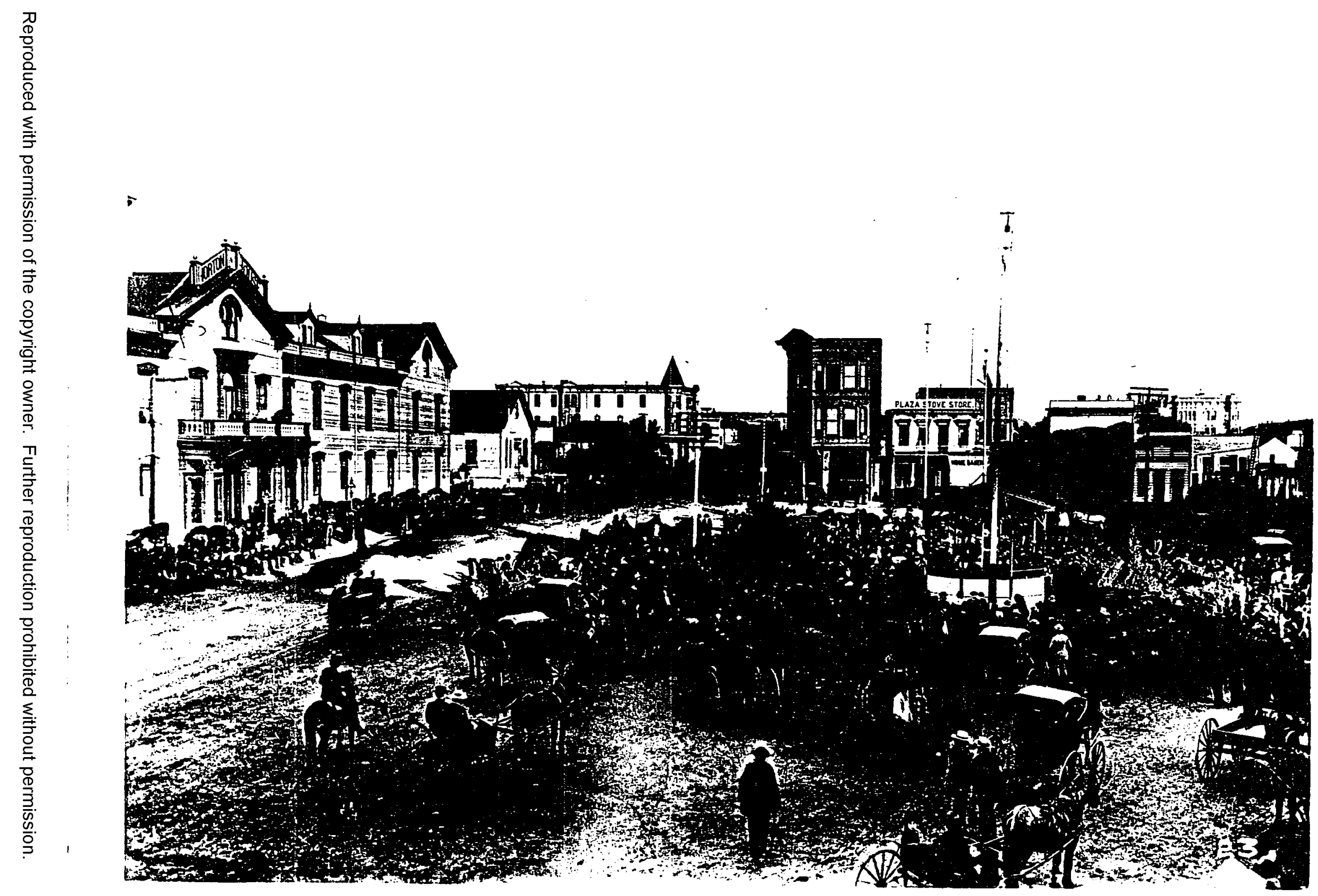


In October 1871, the first homicide was reported in New San Diego. Alexander J. Fenwick shot and killed Charles Wilson. Wilson had an Indian wife whom he accused of infidelity with Fenwick. Fenwick was tried and convicted; on appeal, the Supreme Court affirmed the decision. On May 23, 1873, Fenwick committed suicide with poison. Later, Mrs. Wilson also committed suicide with poison.38 By the year 1871, Border Patrol agents were appointed to help cover the border in the San Ysidro-Tijuana area.39 A few years later, Customs officials were stationed at the border. The border check point was located in a general store just on the United States side of the border. Later border crossers were "checked" at the border official's house which "lay astride the road north of the border." 40 In April 1872, fire destroyed much of Old Town, San Diego's original business district. The fire crushed the hopes of those who were certain Old Town would prevail over the New San Diego. Saving what they could, merchants abandoned Old Town and relocated their businesses to New San Diego. 41

Coklin (1967) said that the traffic which crossed the border at Tijuana heading south into Baja California grew and eventually caused the Méxican government to create a customs port of entry in 
Tijuana in 1874 . The customs house was built in order to collect customs revenue, and in order to support and give substance to that invisible line that was the border. 42

In 1884 , the Santa Fe Railroad came to San Diego and four years later this railroad was extended to the border. In the 1900s, another railroad-the San Diego and Arizona Eastern Line--was built. This railroad served the same border area from Calexico/Mexicali to Tijuana/San Diego. A 45-mile stretch of railroad was built in México and was known as the Ferrocarril de Tijuana y Tecate. This service line was operational until the 1950s. 43

In 1889 , a short-lived gold rush in the mountains south of Tijuana caused a flood of prospectors to head south of the border. The Méxican Customs house that was established 15 years earlier was now levying heavy duties upon returning miners. 44

The town of San Ysidro was known as "Barber's" station from 1869 until about 1900. George Barber, who had been in San Francisco in the early gold rush days, came south and settled in San Ysidro. He operated a general store and an eating house in the adobe station on the San Diego-Ft. Yuma line.45

In the 1860 s agriculture and mining began a rapid expansion 
in the Tijuana region. On July 11,1889 , the City of Tijuana was established in northern Baja California. During this period, Tijuana consisted of twenty adobe dwellings, it had its customs house, area ranches plus a curio store, the new mineral baths of Tijuana Hot Springs Hotel at Agua Caliente, a church, and a school house.46 The gold rush was in the Santa Clara and El Alamo areas of Ensenada, México, southeast of Tijuana. Some 2,000 people arrived and took an estimated $\$ 20,000$ dollars worth of gold by panning. The Méxican Customs officials in Tijuana established a duty fee for the travelers returning to the United States.

"Many who went to the line were brought up short at the Tia Juana customhouse, and unless their papers were made out in order, and their manifests correct, and their bonds for golding and vehicles satisfactory, a cash deposit was demanded as a guarantee that the stock admitted would be brought back out again or the duty paid therefore. By the first week in March several hundred were stalled at the border." 47

By 1890 , San Diego had more than 16,000 residents. Méxican nationals did not begin to migrate, in large numbers, to the United States until the early 1900 s. The 1900 Census showed slightly more than 100,000 Méxican-born persons in the United States. By 1910, this number had doubled to 222,000 persons. This figure again doubled in 1920 to 486,000 persons. Although there was some 
III. Mexican Customs House in Tijuana Baja California Mexico.

Circa 1887. San Diego Historical Society, Photograph

Collection. 


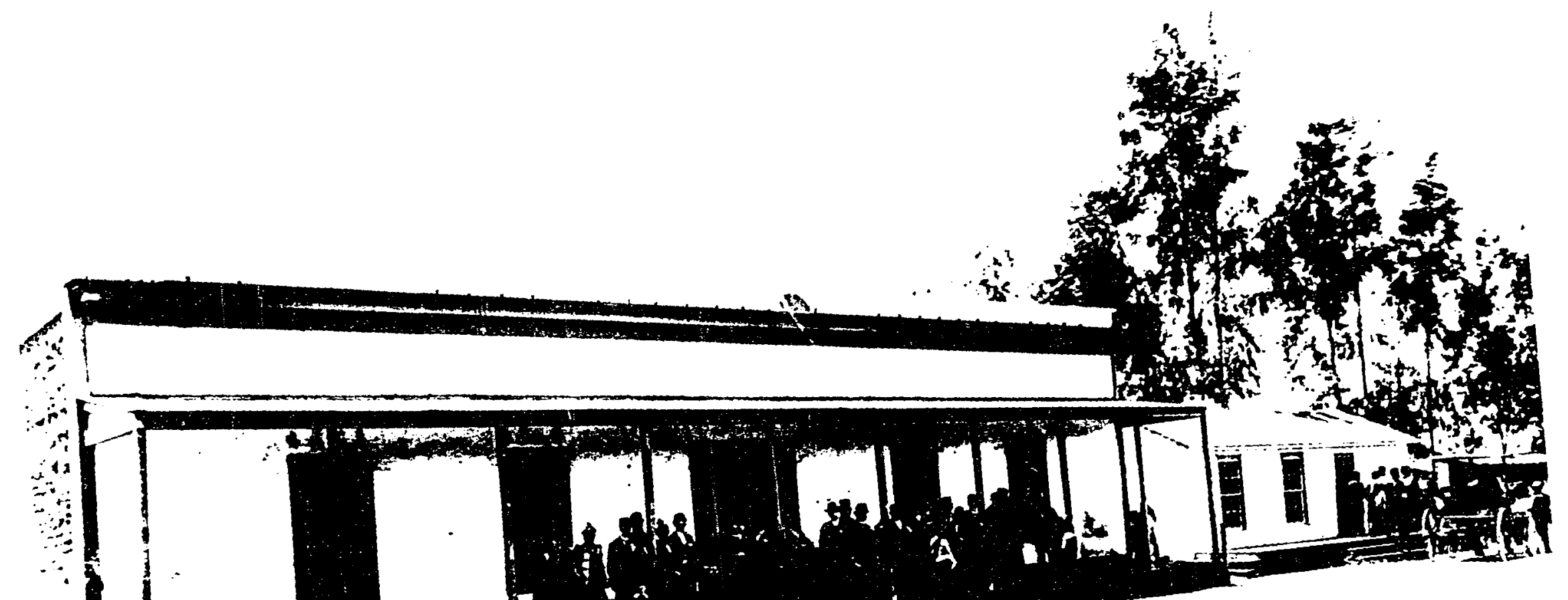


debate over the number of the Méxican-born population in 1930, the first three decades brought a substantial growth of Méxican immigrants residing in the United States. 48

During the first twenty-five years of the century, agribusiness was able to recruit Méxican labor whenever it was needed. The industry developed labor smugglers (coyotes) and contractors (enganchadores) to attract, transport, sell, and exploit Méxican workers. 49

In 1891 a flood ravaged Tijuana, which was then situated on both sides of the border. Another flood in 1895 finished off the town, and people relocated onto two areas of higher ground which later became Tijuana and San Ysidro. In 1910, San Diego had a population of 39,578 residents and Tijuana had about 272 residents. 50

By the early 1900s a small customs house had been relocated "part way up the hill-side".51 This is the present location of the old customs house and the area east of the new Port of Entry at San Ysidro.

In 1908, William Ellsworth Smythe created a cooperative farming colony in the Tia Juana Valley. The land that Smythe chose 
IV. William E. Smythe, founder of the Little Landers Colony. San Diego Historical Society, Photograph Collection. 


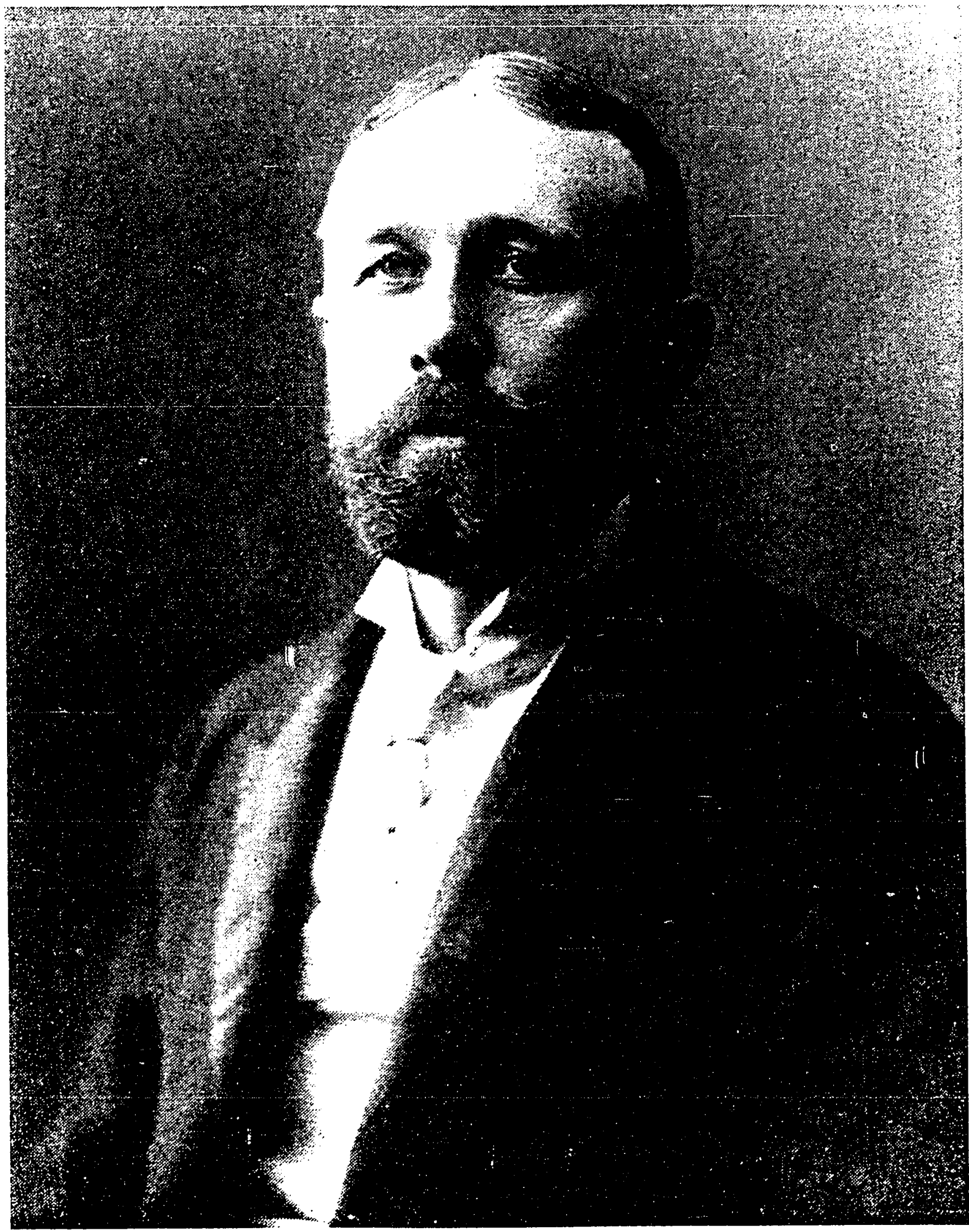


was comprised of three undeveloped ranches, costing $\$ 15,000$.

Although a township had been laid out, very little improvements had been made in the area following the floods of 1891. This great flood also devastated the town of Tia Juana, which was situated directly on the "line" in the river-bottom.

Smythe was able to attract people from all walks of life to the Little Landers Colony; teachers, professors, lawyers, doctors, preachers, artists, authors, bankers, mechanics, and a few farmers. The Little Lander's tract included 550 acres, 150 of which lay in the flat area of the valley and the remaining 400 acres lay on the hillslopes above, where the main part of San Ysidro is now located. The building lots were $25^{\prime}$ by $140^{\prime}$ and sold for $\$ 250$; acre lots sold from $\$ 350$ to $\$ 550$ depending on the location.

The Hotel San Ysidro, at 133 W. San Ysidro Boulevard, became the center of Symthe's club house. Every other Monday, members would gather in the Hotel, and later in the Hall, to argue out their problems in town meetings style of democracy. On the alternate Mondays, they would gather for philosophical discussions, music, and Spanish lessons. The Hotel was originally, according to some people, located in Nestor and served as a railroad depot until it was hauled 
south on a platform by a team of horses. 52

The Little Landers Colony was incorporated on December 10, 1910. George P. Hall was elected president and William E. Smythe was selected vice-president. The community's irrigation district was organized in September 1912, The State Commission and Irrigation District approved a bond of $\$ 25,000$ for the San Ysidro Irrigation District. The voters favored the bond by $90 \%$ in the December elections. By the end of 1912, there were 116 families living in the colony. Members of the colony would farm fruit, vegetables, berries, and kept chickens, ducks, rabbits, cows and goats. Any surplus to the family needs were sold through the Little Landers' town store, located at 6 th and " $B$ " streets. A general store was also maintained in the colony. The colony was named "San Ysidro" as a commemoration of "The Plowman Saint"--the Bishop of Seville, Spain in A. D. 636, famous as a great patron of husbandry said to have been "The greatest writer as well as the greatest churchman of Visigothic Spain" during that period.

The objective of the Iittle Landers Colony was "to show families with little money and little or no farming experience just how they can get to the land without danger of going from bad to 
worse." 53 On January 11, 1909, 12 families had moved into the Little Landers colony, consisting of 50 acres in the Tijuana River bottom. By the end of 1912, there were 116 families living in the Little Landers Colony, all virtually self-sustaining. 54

The profits from the cooperation were used for public improvement. All was going well for the Little Landers Colony until the flood of January 18, 1916. The Little Landers Colony came to an end when the great flood of 1916 washed away twenty-five families, killing two women. The San Diego Union, on Wednesday January 19, 1916, reported that Mrs. Max Kastner and her sister-in-law, Miss Anna Kastner, had drowned when a boat in which an attempt was made to rescue them struck a submerged post and overturned. W. E. Eddie, a member of the rescue party, yelled loudly to everyone in the river, to remain calm and try to keep afloat for a few minutes. It was pitch dark when the boat overturned, and although the rescuers were aided by the lanterns of those on shore, the two women could not be found. 55

The Kastner family was one of the last families to leave the river bottom. The women piled the furnishings high in the house and started to cross the flooded fields at dark. The water was from 
six inches to eight feet deep and when the women got to a point where it was too deep, they waited for the rescue party. The rescue party was making its way to the women. The women climbed into the boat and were but a few yards from higher ground when the boat struck a hidden log, stump, or tree and overturned.56 The bodies of the women were never recovered. It is thought the bodies may have been carried to sea. 57

One hundred families were left destitute as a result of the flood which washed away their homes and left their land under three to eight feet of water. Sheriff Ralph Coklin, who with Deputies Williams Landis and Ed Goset and a party of sailors from the torpeci o-boat destroyers Hull and Hopkins, went to San Ysidro via the Strand route early Wednesday morning, to help in the relief effort.58

Most of the residents of the Little Landers Colony lost everything they owned. The flood not only took their homes, it also washed away their farms, leaving them in the bed of the river. At least six houses were washed away and others were on their sides.59

Smythe appeared before the Common Council, appealing, as he said, "to the generous people of San Diego to lend a helping hand in this hour of need to men, women, and children who are fighting, not 
V. Map of San Diego-Tijuana Border Area. 


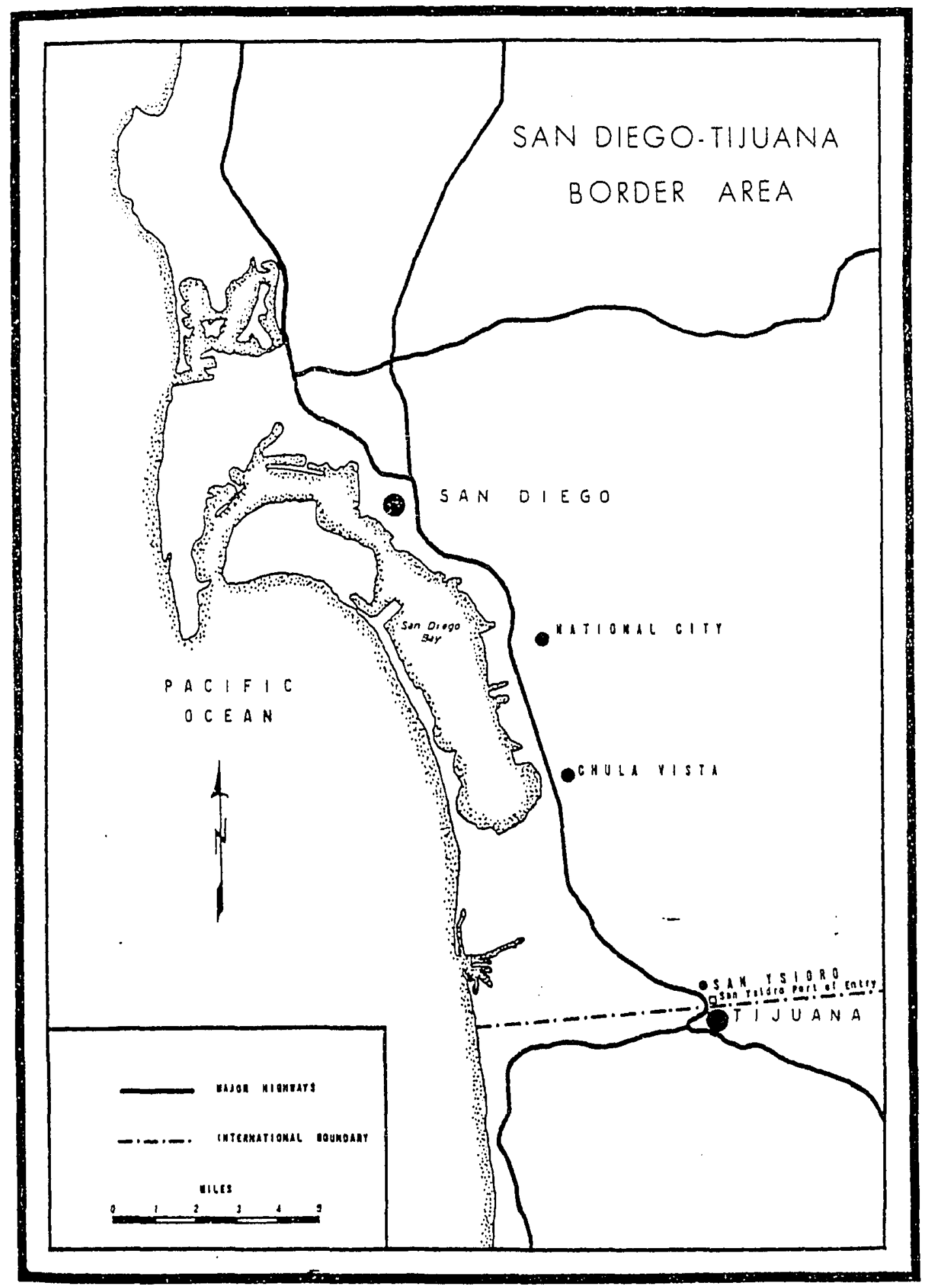

vsidro, California.

Location of the port of entry at San 
merely for their homes, but for a system of life on the land which means much to the entire world. ..."60

In addition to the damage caused by the flood, the incomplete and ineffective water system caused problems for the members. The "Industrial Workers of the World (I.W.W.) Insurrection," which flared along the border for several years, caused disturbances along the river-bottom, and World War I, took many young men away from the Colony. Through the 1920s the Little Landers faded away, in part because of the causes already mentioned, and also with the passing of William Smythe in 1922.

The original Little Landers Corporation was legally dissolved on November 30,1912 , for not paying franchise taxes. 61 The irrigation land and pumping station were taken over by the City of San Diego in 1956.62

Mattie Larsen, a long time resident of San Ysidro and a school teacher, taught the eighth grade and later the sixth grade. She would invite some 30 children from Tijuana in order to fill her classes. Larsen also worked as a Customs agent from 1911-1913.63

Mattie spent many years away from San Ysidro but returned to teach in 1935. In 1947, Larsen became the first San Ysidro school 
VI. Tijuana tourist crossing the Tijuana River at San Ysidro.

Circa 1890s. San Diego Historical Society, Photograph Collection. 


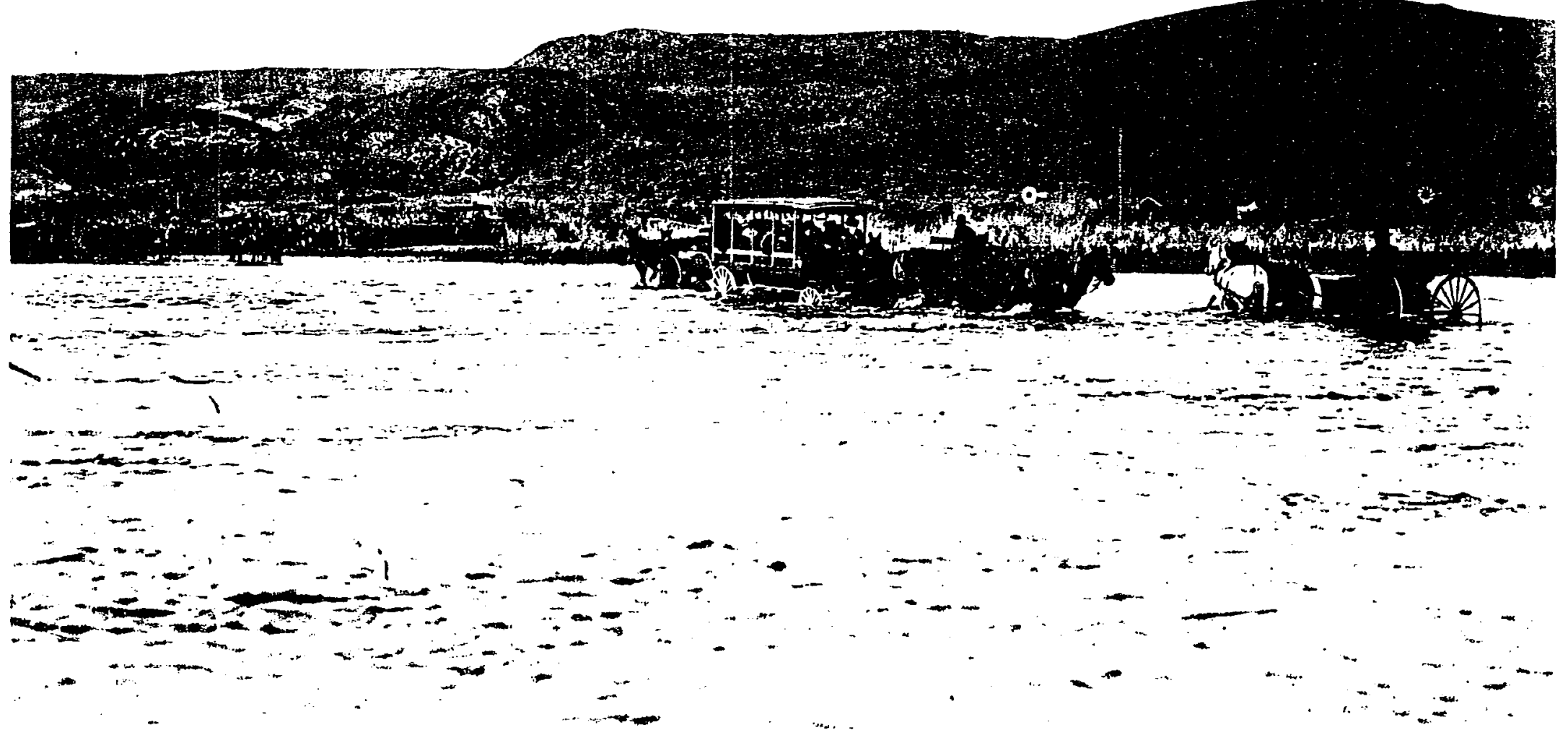


VII. Tijuana flood of 1927 at San Ysidro, California. San Diego Historical Society, Photograph Collection. 


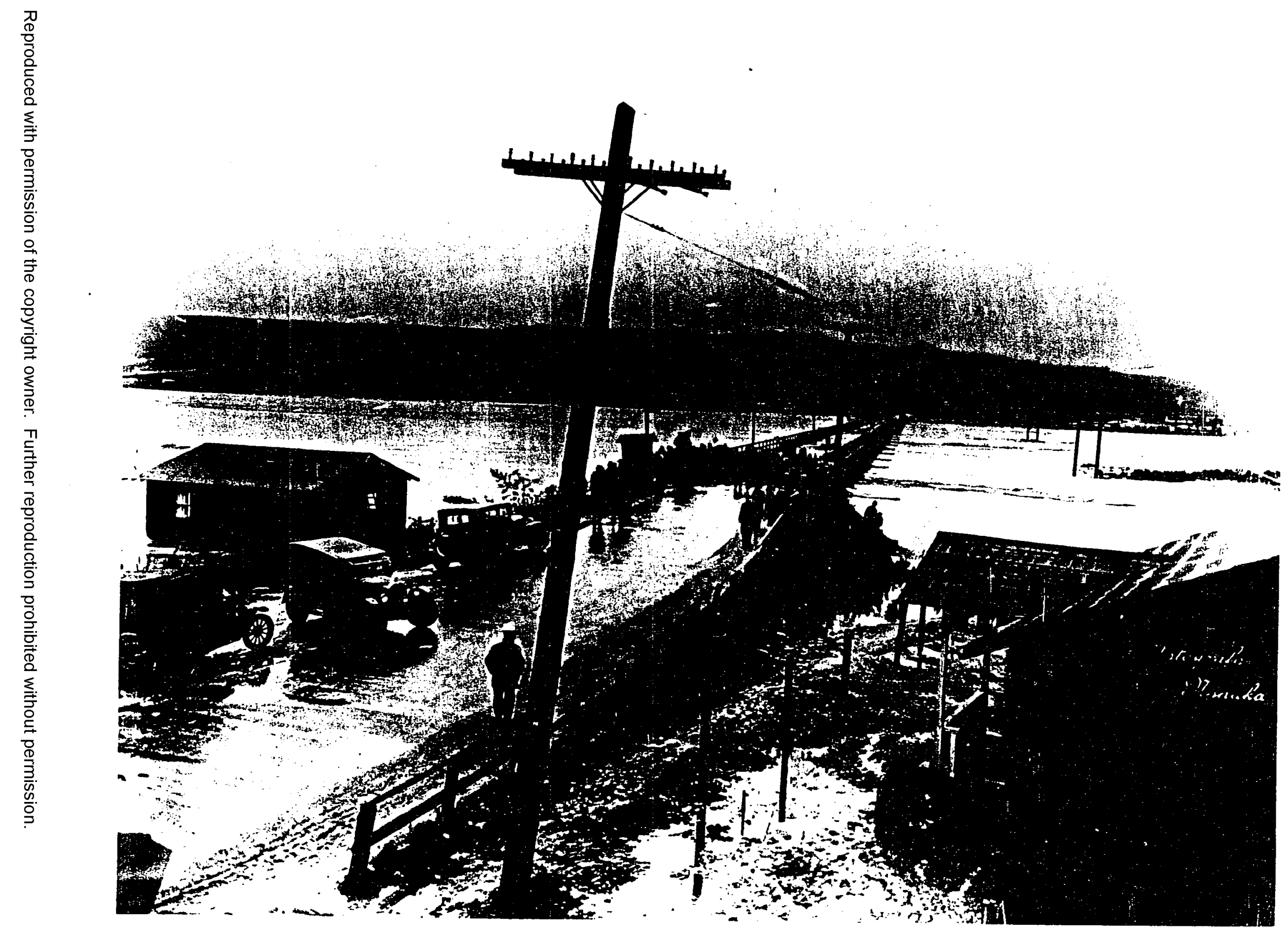


superintendent in San Diego County. She believed in teaching the three Rs.64 A while back, the water district donated a plot of San Ysidro land to provide a place for Little League baseball games. Mattie Larsen was invited to see the new park, she was completely overwhelmed to learn that it was named "Larsen Sports Park" in her honor.65 Mrs. Larsen passed away in 1968.

This border region, like most of the United States-Méxican boundary, had its share of bandits and violence over the years. When the level of banditry increased people tended not to cross the border. The periods of instability and violence in this border region reached a climax during the 1910-1911 Méxican Revolution. The City of Tijuana, because of its frontier location, was harassed by revolutionaries operating out of the United States. 66 The confrontation of factions was climaxed on May 8, 1911, at the Battle of Tijuana.67 Tijuana/San Ysidro Border Region: 1910 - 1957

Between 1910 and 1930, about 10\% of the Méxican population had immigrated to the United States. The Immigration Act of 1917 was created to restrict the flow of Méxican immigration. This law placed a "head tax" on Méxicans and also included a literacy examination which they were expected to pass. By the end of 1930 , 
VIII. Tijuana Baja California Mexico, view from the international border, Circa 1910. San Diego Historical Jociety, Photograph Collection. 


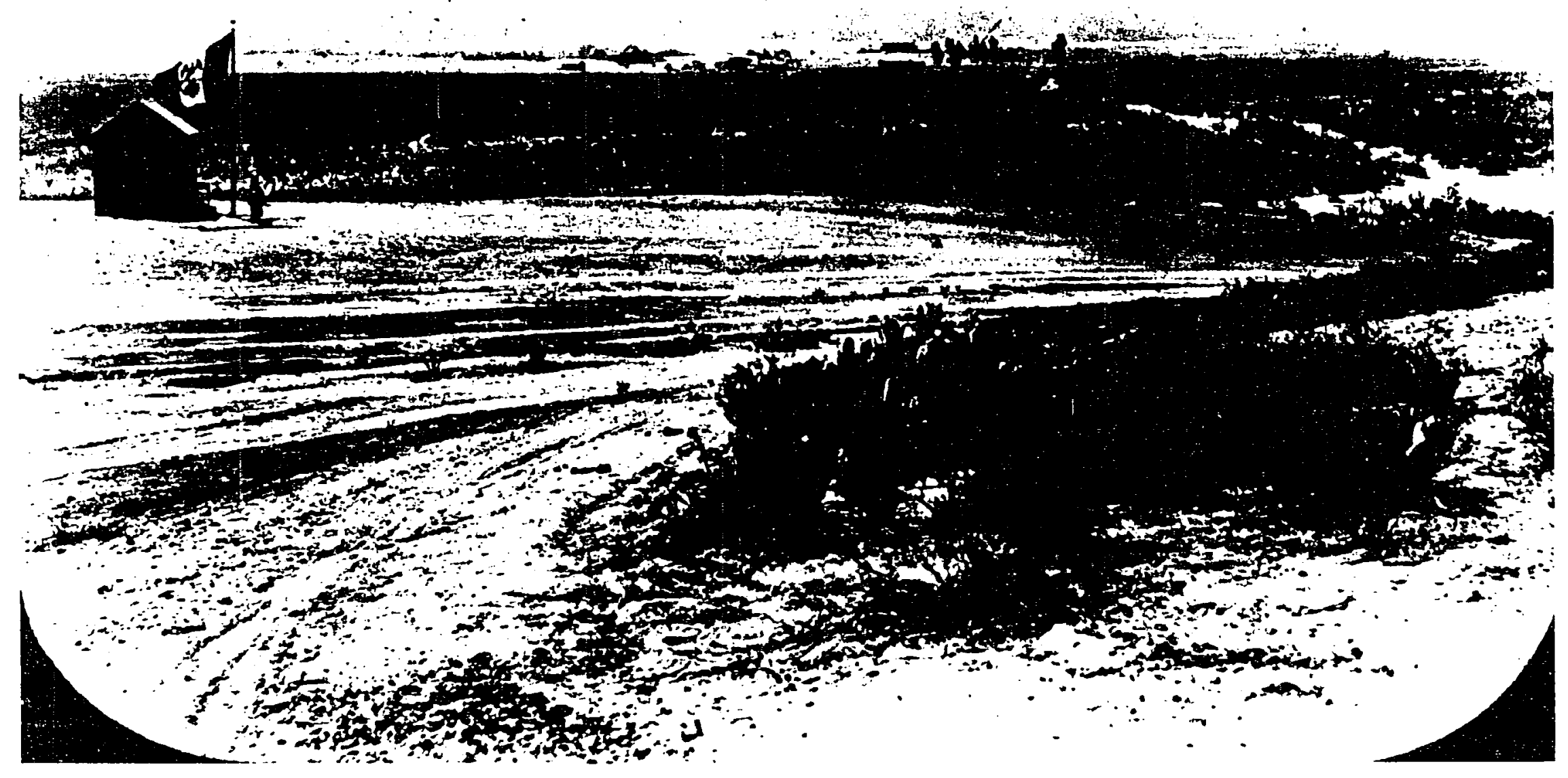


there were about 148,000 Méxicans living in the San Diego region. During the Great Depression, many immigrants and American-born Méxicans, more than 400,000 workers across the country, were arrested and deported.68

In 1915, the San Diego International Exposition opened in Balboa Park. The Exposition attracted thousands of visitors to San Diego, many of who wanted to visit Tijuana and "see México." In order to complement the San Diego Exposition and widen the attraction to Tijuana, México built the Tijuana Fair. The Fair offered bullfighting, boxing, and gambling, all of which were illegal in the United States.

The first Tijuana horse race track opened on January 1, 1916. The event was nationally publicized as, "the greatest winter racing in the United States." Over ten thousand people attended the opening day. James Cofforth, promoter, influenced the growth of the border region. He did such an impressive job, that an entire series of articles about him were written entitled, "The Man who built Tijuana."69

Despite the damaging floods of 1916 , which destroyed the Little Landers Colony, Tijuana racing officials planned another racing 
IX. San Ysidro/Tijuana border crossing, Circa 1918. San

Diego Historical Society, So. California Auto Club collection. 


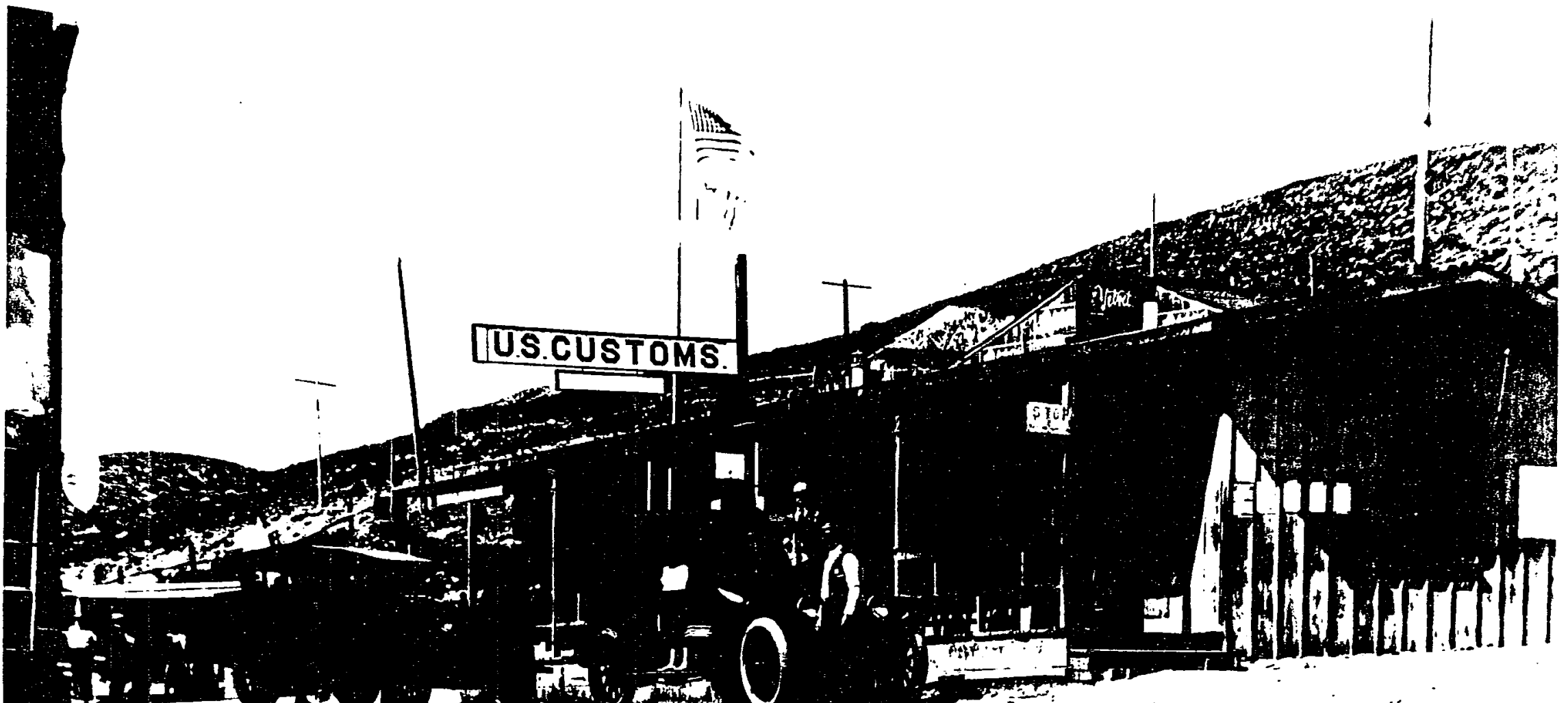

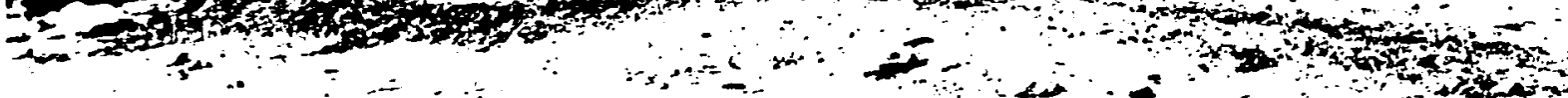

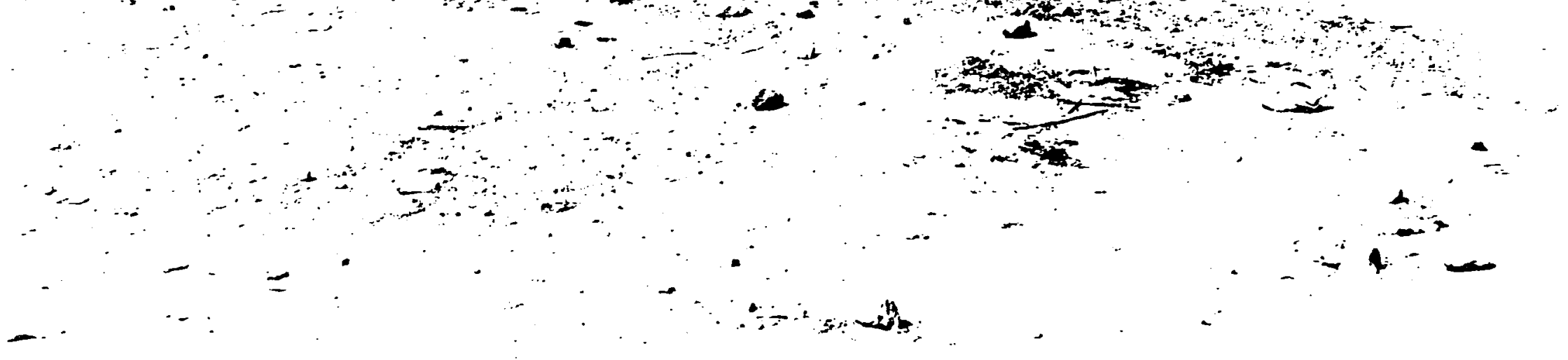


X. San Ysidro/Tijuana border crossing, looking north towards San Ysidro from Tijuana, Circa 1922. San Diego Historical Society, Photograph Collection. 


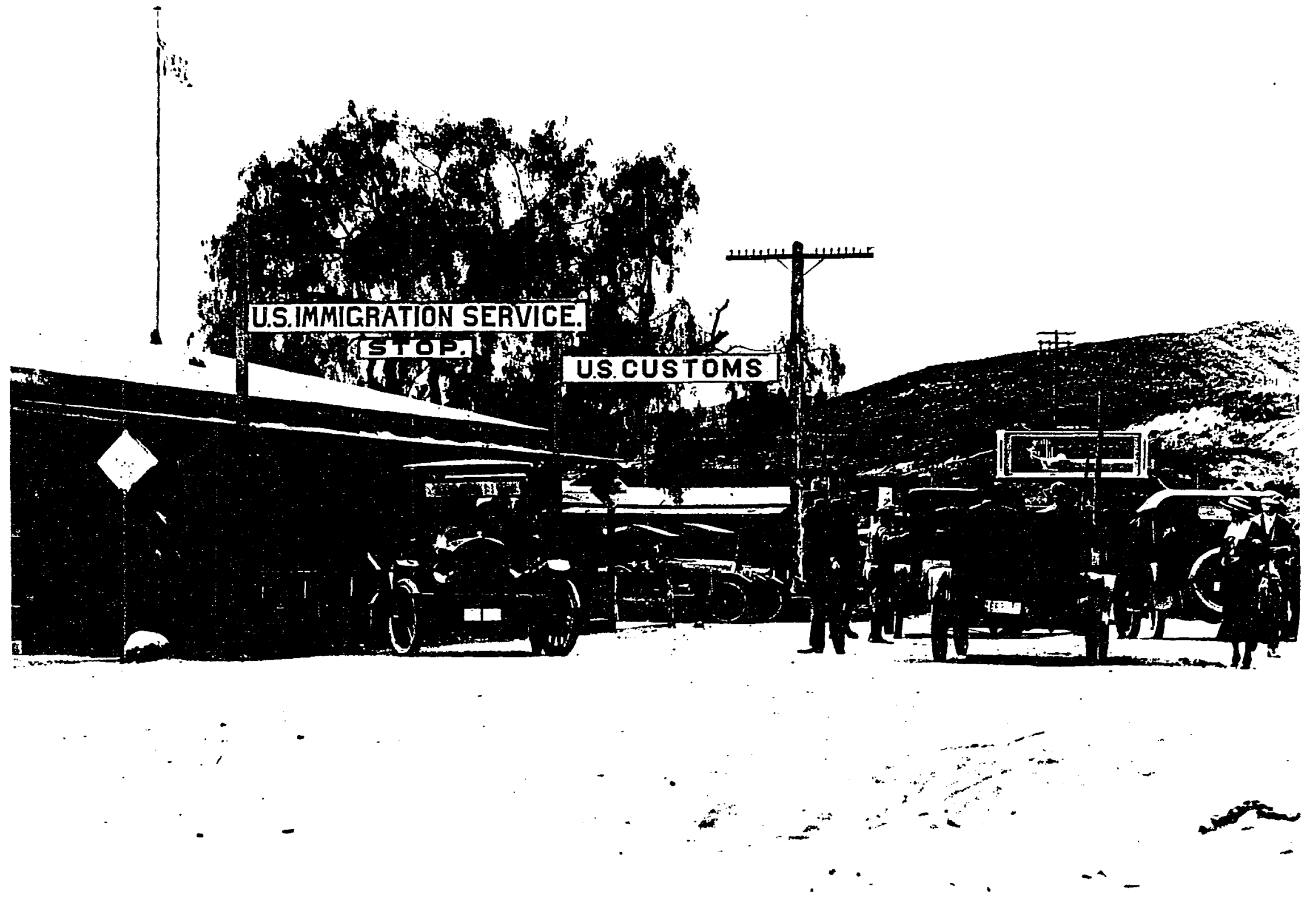


season. The involvement of the United States in World War I, however, forced the suspension of the racing season. During this period, many military bases were being established in the San Diego area, but the City of Tijuana was put off-limits to U. S. servicemen.

Late in 1917, the United States Immigration and Naturalization Department began to require a passport for people crossing the United States and México border. This was a severe restriction on the free travel across the border. Because of the growing reform movement in the United States against Méxican border "vice," Pancho Villa type raids, and the War itself, the United States/México international border was closed to all traffic in December 1917.70 The international United States and México border was reopened in 1920 . In January 1920, the 18 th Amendment made the selling and possession of alcoholic beverages illegal in the United States. Drinking alcoholic beverages was legal in México. Tijuana turned into a Prohibition boom town almost over night. On July 4, 1920 , an estimated 65,000 people were reported to have crossed the border into México at the San Ysidro-Tijuana border.71 Despite the prosperity Tijuana had given San Diego, local reformers joined national groups to put pressure upon the United States government 
XI. San Ysidro Port of Entry at the San Ysidro/Tijuana border crossing. Circa 1925. San Diego Historical Society, Photograph Collection. 


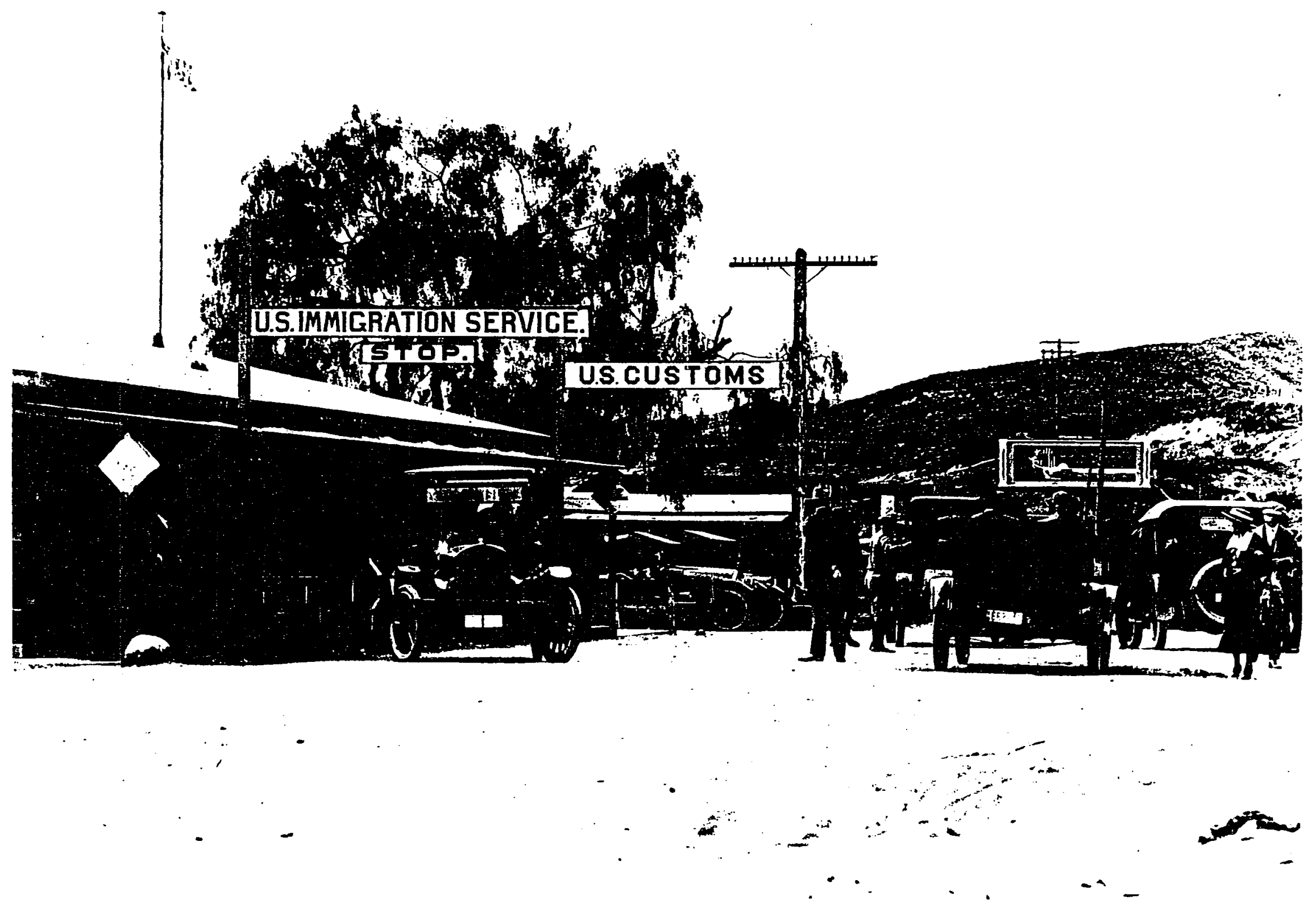


season. The involvement of the United States in World War I, however, forced the suspension of the racing season. During this period, many military bases were being established in the San Diego area, but the City of Tijuana was put off-limits to U. S. servicemen.

Late in 1917, the United States Immigration and Naturalization Department began to require a passport for people crossing the United States and México border. This was a severe restriction on the free travel across the border. Because of the growing reform movement in the United States against Méxican border "vice," Pancho Villa type raids, and the War itself, the United States/México international border was closed to all traffic in December 1917.70

The international United States and México border was reopened in 1920. In January 1920, the 18 th Amendment made the selling and possession of alcoholic beverages illegal in the United States. Drinking alcoholic beverages was legal in México. Tijuana turned into a Prohibition boom town almost over night. On July 4, 1920 , an estimated 65,000 people were reported to have crossed the border into México at the San Ysidro-Tijuana border.71 Despite the prosperity Tijuana had given San Diego, local reformers joined national groups to put pressure upon the United States government 
XI. San Ysidro Port of Entry at the San Ysidro/Tijuana border crossing. Circa 1925. San Diego Historical Society, Photograph Collection. 


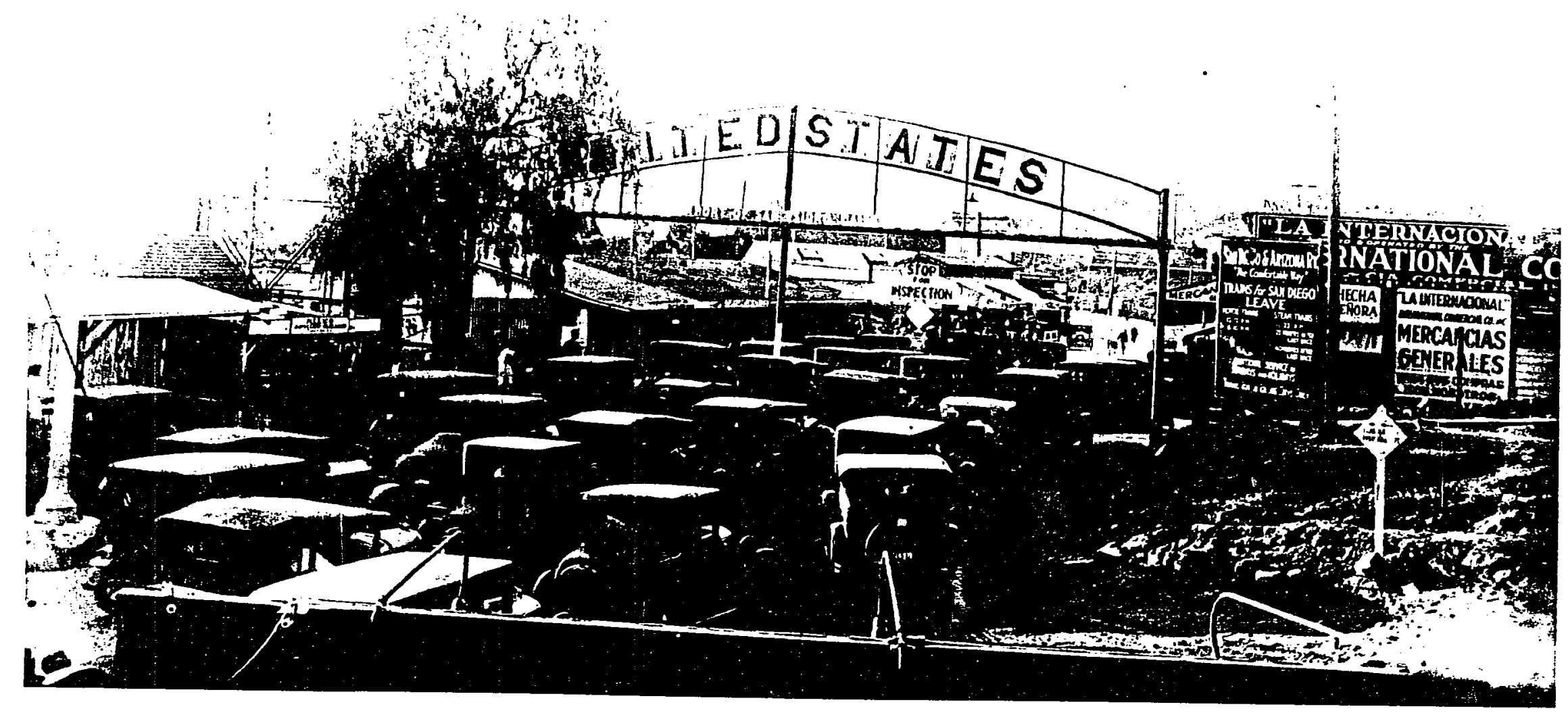


to close down the international border. In March 1924, the U. S. government yielded to group pressure and began to close the border stations at 9:00 p.m. The pressure forced the government to use more restrictive measures. Early in 1926 , a 6:00 p. m. curfew was imposed on the international border.

During the 1920s, those who crossed the border noticed that the inspections were quick, even though customs officials were supposed to be on the look-out for smugglers (illegal alcohol). The only delays were in traffic lanes at busy periods, at gate closing time, and on major holidays when the lack of customs inspectors required holding the line open until 9:00 p. m., just long enough to allow those people waiting through the inspection line. 72

In 1942, a series of intergovernmental agreements between the United States and México created the bracero program. This program allowed for the importation of Méxican labor for periods of six months at a time. By late 1950 there were half a million braceros in the United States. This number declined steadily until 1964 when 177,000 braceros entered; 107,000 of them came to California. Although the bracero program was meant to be a temporary war time measure, it did not come to an end until 1964.73 
XII. United States and México border crossing. To remind people of the border closing, a sign reads, "Line closes at 9 p.m. to both vehicles and foot traffic by order of U.S. Customs." San Diego Historical Society, Photograph Collection. 


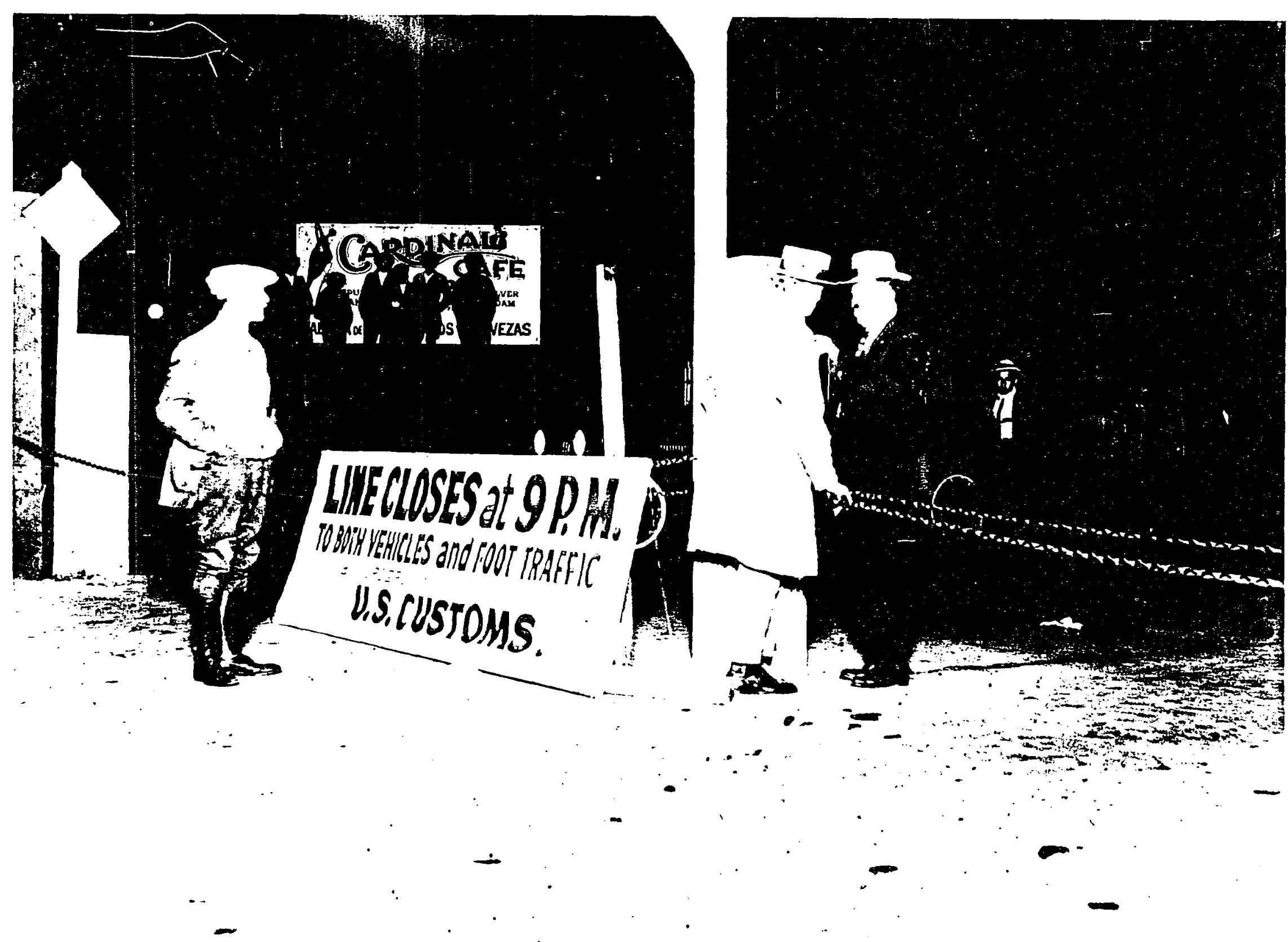


In 1957, the City of San Diego annexed the San Ysidro community, including Palm City, Nestor, and Otay Mesa. This annexation brought the San Diego's city limits up to the international border. Although San Ysidro is politically part of San Diego, San Ysidro is separated from San Diego by the municipalities of Chula Vista and National City. Downtown San Diego is about 16 miles north from the San Ysidro-Tijuana Port of Entry.74

The San Ysidro-Tijuana border crossing was originally located on the floor of the Tia Juana River Valley at the international boundary line. Before 1895 primary traffic flow from Tijuana to San Diego and the old customs houses were located in this region. However, because of the persistent winter flooding, the border crossing was moved 1,000 meters east to higher ground. 75

The San Ysidro-Tijuana Port of Entry is presently located six miles east from the Pacific Ocean and on the northern edge of the Tia Juana River Valley on the southwest facing slope of the Otay Mesa about 75 feet above sea level.76 The San Ysidro Port of Entry (POE) is the largest border POE on the United States/México border, both on the number of primary inspection lanes and in the amount of vehicular traffic. During the fiscal year 1994, the United States 
government inspectors processed more than 43,842 vehicles and 25,389 pedestrians a day, making it the busiest port in the United States. The San Ysidro Port of Entry is open 24 hours a day, seven days a week.77

In addition to the San Ysidro Port of Entry, San Diego now has a second Port of Entry located in the Otay Mesa, in South Bay. The Otay Mesa Port of Entry (POE) is primarily a commercial Port of Entry, operating 16 hours per day, from 0600 to 2200 hours. This Port of Entry is about nine miles east of the San Ysidro Port of Entry. The Otay Mesa Port of Entry handles all commercial land entries to the San Diego area, including a large number of trucks commuting between San Diego and Tijuana, maqilladoras (twin plants). Tijuana is home to one of the most concentrated maqilladora operations on the United States/México border. The area on both sides of the border surrounding this POE is zoned for commercial development with many new facilities currently under construction, adding to the already heavy flow of traffic. Otay Mesa was the site of a drug cartel underground tunnel between Tijuana and San Diego, discovered in 1993.78

Access across international boundaries are guarded for various 
XIII. San Diego/Tijuana border region. San Ysidro Port of Entry and the second port of entry at Otay Mesa, 1987. Photo from Lawrence A. Herzog, Where north meets south: Cities, space, and politics on the U. S. -Mexico border. University of Texas at Austin, 1990. 
reasons such as health, tariff regulations, controlling immigration, and defense. The political policies and trends of a country are reflected in its liberalization or tightening of its border crossing controls. All persons entering the United States across its international borders must report their entrance to an agent of the United States Immigration and Naturalization and/or Customs Service, at a designated port of entry. Under the authority in Section 235 (a) of the Immigration and Nationality Act, an authorized United States inspector may question any person under oath coming into the United States to determine citizenship. The Department of State does not require a passport for citizens returning to the United States after travelling exclusively in México.79

An alien, as defined by the United States Immigration and Naturalization Service, is a person who is not a citizen or a national of the United States, must show either an Alien Registration Receipt Card (resident) or a Nonresident Alien Méxican Border Crossing Card (nonresident). A resident alien enjoys all of the rights of United States citizens, except the right to vote and the right to hold public office. A resident alien is required to pay taxes, may serve in the military forces, and most importantly, may obtain employment. A 
nonresident alien, on the other hand, may only cross the border for a period of up to seventy-two hours within a twenty-five mile limit of the Méxican border. Although the nonresident alien crossing permit is easy to obtain, the holders of such cards are strictly forbidden to accept employment of any kind while in the United States. The purpose of this type of permit is to allow the holder the convenience of shopping and visiting relatives within the international frontier area of the United States. 80

Between July 1930 to June 1931, an estimated five and a half million people crossed into the United States at the San Ysidro port of entry. Well over 90 percent of these people were United States citizens. Unlike the previous war, the San Ysidro port of entry was never closed during World War II. There were the inevitable war time restrictions however. Even before Pearl Harbor, in order to detect German nationals, people crossing the border were inspected as they left the country. This inspection included censorship, written material was not allowed to leave the country. Another restriction was the " $\$ 2.00$ bill rule." A $\$ 2$ bill was the only type of U.S. currency allowed to be taken in and out of México. A two hundred and fifty dollar total limit was also in effect.81 
In the early 1940s, Méxican border crossings passed the one million mark. In the postwar years, the number of border crossings began to increase. In $1945,4.5$ million people crossed at the San Ysidro port of entry; by 1949 this number reached the 7.5 million mark. Although millions of people cross annually through the San Ysidro-Tijuana border Port of Entry, thousand more cross illegally through the east and west side of the Port of Entry. 82

In addition to illegal immigration, legal immigration was also on the increase. Prior to 1950 , the vast majority of legal immigrants arrived from Europe. However, from 1950 to 1990, a new wave of legal immigrants began to arrive in the United States, many immigrants were from Latin America. Between 1951 and 1960, over 2.5 million people entered the country legally. Of those, 1 in 5 came from Latin America. Between 1961 and 1970, 3.3 million immigrants entered the United States, with 1 in 3 coming from Latin America. During the 1970 s, there were nearly 4.5 million immigrants, with about 40 percent coming from Latin America. 83

In the early 1950s, the San Diego County District Attorney started a campaign which would prevent unescorted juveniles (under the age of eighteen) from entering México, unless they had written 
permission from their parents or legal guardians.84 The program was so successful that a police check point was established on the south bound lanes at San Ysidro port of entry in December, 1957.

On November 23, 1963, the Méxican government again closed the international border, to land border crossing, because of the assassination of President John F. Kennedy. This was done as a precaution to cut off any escape route for the assassins. As the events of that Friday and Saturday were resolved, the border blockade was lifted after 19 hours of closure. 85

Martínez (1994) proposed four models of borderland interactions: alienated, coexistent, interdependent, and integrated.

Under the alienated borderlands, the residents of each country do not interact with the other. These people view each other as strangers. The border is closed, with little or no interaction. Under the coexistent borderlands model, the residents view each other as acquaintances and there is limited binational interaction. Under the interdependent model, residents are friendly and cooperative with each other. Economic and social factors increase border interactions between both countries. This model is currently operating at the Tijuana/San Diego border crossing. Finally, under the integrated 
borderland, residents from each country view themselves as members of a single social system. The economy of both countries are merged and the jeople and goods can move freely across the border. 86

The historian Herbert Bolton termed the border region the "Borderlands." 87 The alienation period was between the 1560 s and the 1880s. Spain moved northward into what is now Florida and to the southwest from the Caribbean and central México. Britain controlled the east coast, while France controlled the region from the Great Lakes to the Mississippi River valley. In 1803, the United States purchased Louisiana from France, which had acquired it three years earlier from Spain. In 1821, when México became an independent nation, the United States tried to purchase the regions of New México and California, but México refused to sell them. During the 1820 s and the 1830 s, a large-scale American immigration into Texas caused a war for independence and eventually Texas was annexed by the United States in 1845.88

With tension already high between the United States and México, war erupted between the United States and México in 1846. In 1848 , the Treaty of Guadalupe Hidalgo was signed and the war 
came to an end. Five years later, the Treaty of Gadsden transferred additional Méxican land -- southern New México and southern Arizona to the United States. 89

During the coexistence period between the 1880 s and the 1920s, Porfirio Diaz, President of México, developed a binational relationship between the United States and México that led to a businesslike association. 90

The interdependence period from the 1920s to the present, saw the United States and México debate for decades the issue of undocumented Méxicans crossing to the United States. 91

In 1962, over 21 million persons crossed the border from Tijuana, México into the United States at the San Ysidro port of entry. Border crossers at the San Ysidro port of entry pass either as pedestrians or in vehicles. Most of these people are unaware that they are being screened by personnel from four federal agencies. 92 San Ysidro is a Class A port of entry and is patrolled by the following four agencies: Immigration and Naturalization Service, Customs Service, Department of Public Health, Education and Welfare, and Department of Agriculture. Under an order by the late President Kennedy, these four agencies started a primary and secondary 
inspection system in the interest of service to travelers and government efficiency. 93

The United States Immigration and Naturalization Service (INS) is the primary federal agency with the responsibility of inspecting and admitting persons into the United States. These agents are concerned with the right of people to enter the country. INS has the final jurisdiction over every person crossing the border, and this agency has the responsibility for issuing documents to incoming aliens. 94

The United States Customs Service has a major responsibility with traffic inspection. Its primary function is the enforcement of tariff regulations of imports and exports. Customs agents are to protect the nation's revenue through the prevention of fraud and smuggling. At the San Ysidro port of entry, Customs' efforts are traditionally taken up in prevention of smuggling. 95

The United States Department of Public Health, Education, and Welfare, is responsible for preventing the introduction of communicable diseases into the United States. Personnel from this agency inspect traffic lanes and also provide medical examinations to prospective immigrants. 96 
The last primary inspection agency is the United States Department of Agriculture. This agency regulates the produce coming into the United States, and certifies produce exported from the United States to meet the sanitation requirements of other countries. The produce being imported is checked to prevent the entry of pests that might infest crops in the United States. This is achieved through the quarantine of certain fruits, vegetables, and plants, by inspectors on the pedestrian lanes, and by examining incoming cargo and baggage. 97

Additional federal, state, and local agencies also maintain small staffs at the San Ysidro/Tijuana border station. These include the United States Border Patrol, federal narcotic agents, Shore Patrol, California Highway Patrol, and San Diego Police Department. While personnel from these agencies do not patrol the lanes at the border, they assist in carrying out the mission of the inspection services as well as their own duties and responsibilities. 98 History of the San Diego Police Department: $1889-1957$

The history of the San Diego Police Department may date back to May 16,1889 , at which time it was organized under "The Freeholders Charter." It was not until the adoption of the Freeholders 
XIV. San Ysidro/Tijuana International Border, September 21, 1969. San Diego Historical Society, Photograph Collection. 


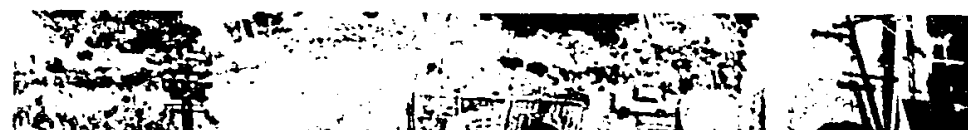

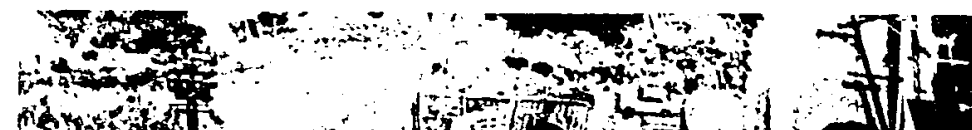
(3)

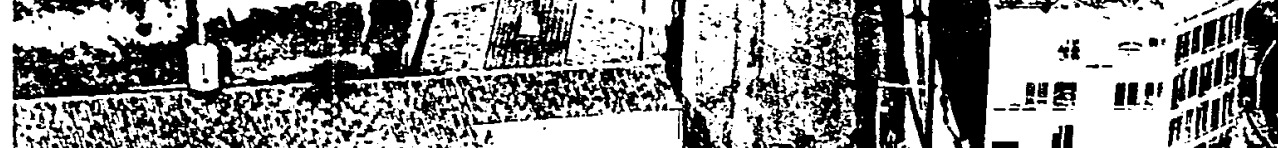

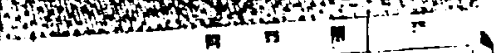

-15

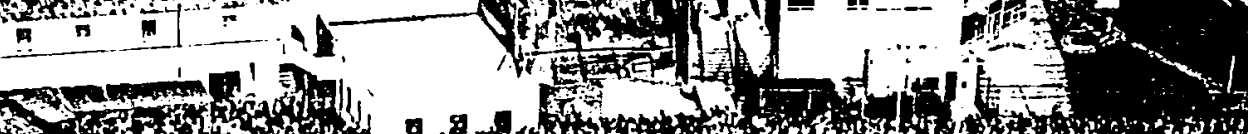
(fint,

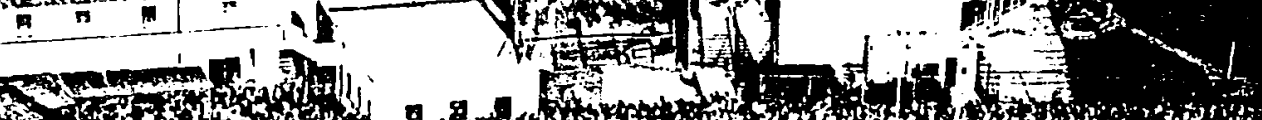

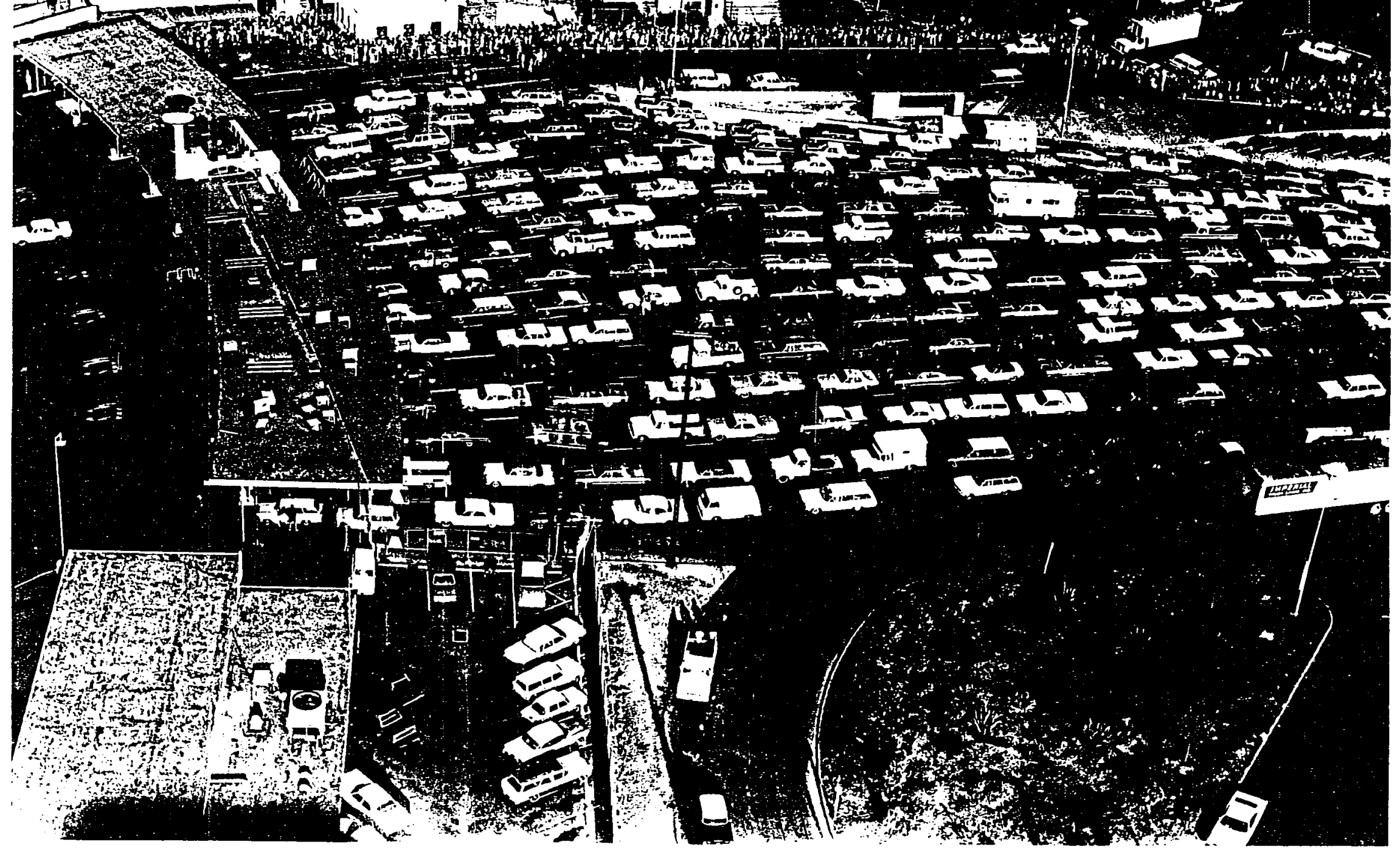


Charter that the City of San Diego was placed upon a metropolitan basis.99

On April 1, 1850, Agustín Haraszthy was elected the first Sheriff of San Diego County, and in the same election, one of the first held in California, his father, Charles, was elected to the city council. The City of San Diego awarded Agustín Haraszthy a $\$ 5,000$ dollar contract for the construction of the Cobblestone City jail. A bid of $\$ 3,000$ dollars submitted by the Israel Brothers was rejected by the City Council, of which Charles Haraszthy was a member.100

The jail was built of cobbles laid in mortar with no cement. During construction the jail was partially damaged by a rainstorm. Agustín Haraszthy asked the City Council for an additional $\$ 2,000$ to complete the structure. The additional funds were paid to Agustin Haraszthy in city scrip, because the city treasury did not have any money. Some of this scrip was later exchanged for city land, but in 1853 the town trustees resigned in a body rather than honor the balance, because the jail was so poorly constructed that the first prisoner sent there managed to dig himself out in a matter of minutes. Sheriff Agustín Haraszthy's office was located a few doors from the northeast corner of the plaza on Calhoun Street.101 
XV. Cobblestone Jail in Old Town. Photo taken in 1870, courtesty of the San Diego Historical Society, Photograph Collection. 


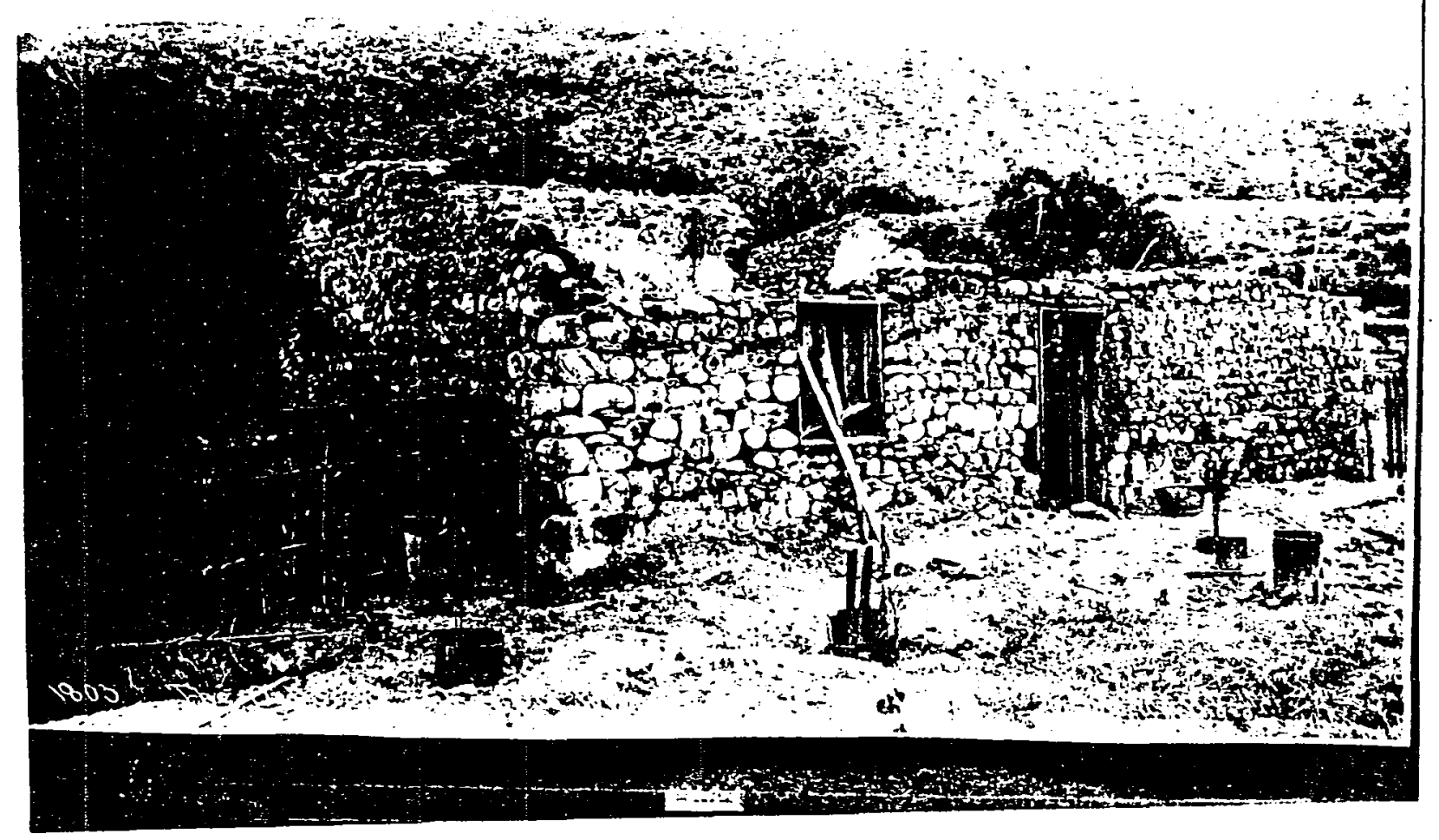


Sheriff Agustin Haraszthy was sent to collect tax revenues on local Indian tribes' livestock. He collected $\$ 600$ from the Diegueño, Luiseño, and Cupeño tribes that where living near the Warner ranch. When the Indians refused to pay additional taxes, Sheriff Agustín Haraszthy threatened to seize their cattle, a few would pay but most of the tribes, which were led by Chief Antonio Garra, decided to take a stand. The U. S. Army which had been stationed in San Diego had recently been relocated to Fort Yuma, leaving behind only a lieutenant, a corporal and nine enlisted men. When the Indians attacked and burned the Warner ranch, San Diego prepared to defend itself. A rolunteer company was formed under Major E. F. Fitzgerald with Sheriff Agustin Haraszthy as the First Lieutenant. During this time, a relief column of U. S. Army from Ft. Yuma responded and arrived in El Cajon on December 21st, just in time to save the town. On December 27, Sheriff Agustín Haraszthy and a small volunteer group rode out to the Cupeño Indian village and burned it. Between 1850 and 1889, the Sheriff was the main law enforcement officer in the County. 102

In 1863, Sheriff James McCoy was given the formal title of "Chief of Police," so that he could better protect the people from 
exposure to smallpox disease. The Sheriff was also directed to prevent any person residing in infected areas from entering the City, and, if any such person were caught in town, to promptly eject them. Sheriff James McCoy was ordered to command all undesirable Indians and Méxicans, who were not employed, to leave town within 12 hours. 103

In the late 1840 s and early 1850 s, officers of the San Diego Police Department first wore a seven-point star badge and later the badge was changed to a six-point star badge. Today, the officers wear a gold shield as their badge.

The City of San Diego was incorporated in 1888 and established its police department on May 16, 1889.104 Joseph Coyne (18891891) was the first Chief of Police. Prior to being appointed as Chief of Police, Joseph Coyne served as the Sheriff of San Diego County from 1876 to 1882.105 Before 1889 , the City of San Diego had Deputy City Marshals providing the police service. In addition, the City of San Diego expanded from 12 square miles to 78 square miles. This expansion, under the Freeholder's Charter, included the Coronado peninsula, North Island, and all of the bay areas to the City's boundaries.106 


\section{The first San Diego Police Department Chief of Police, Joseph Coyne (1889-1891). San Diego Historical Society, Photograph Collection.}


CHIGF OP POLICE

S.D. POICE DEPT. ITOO

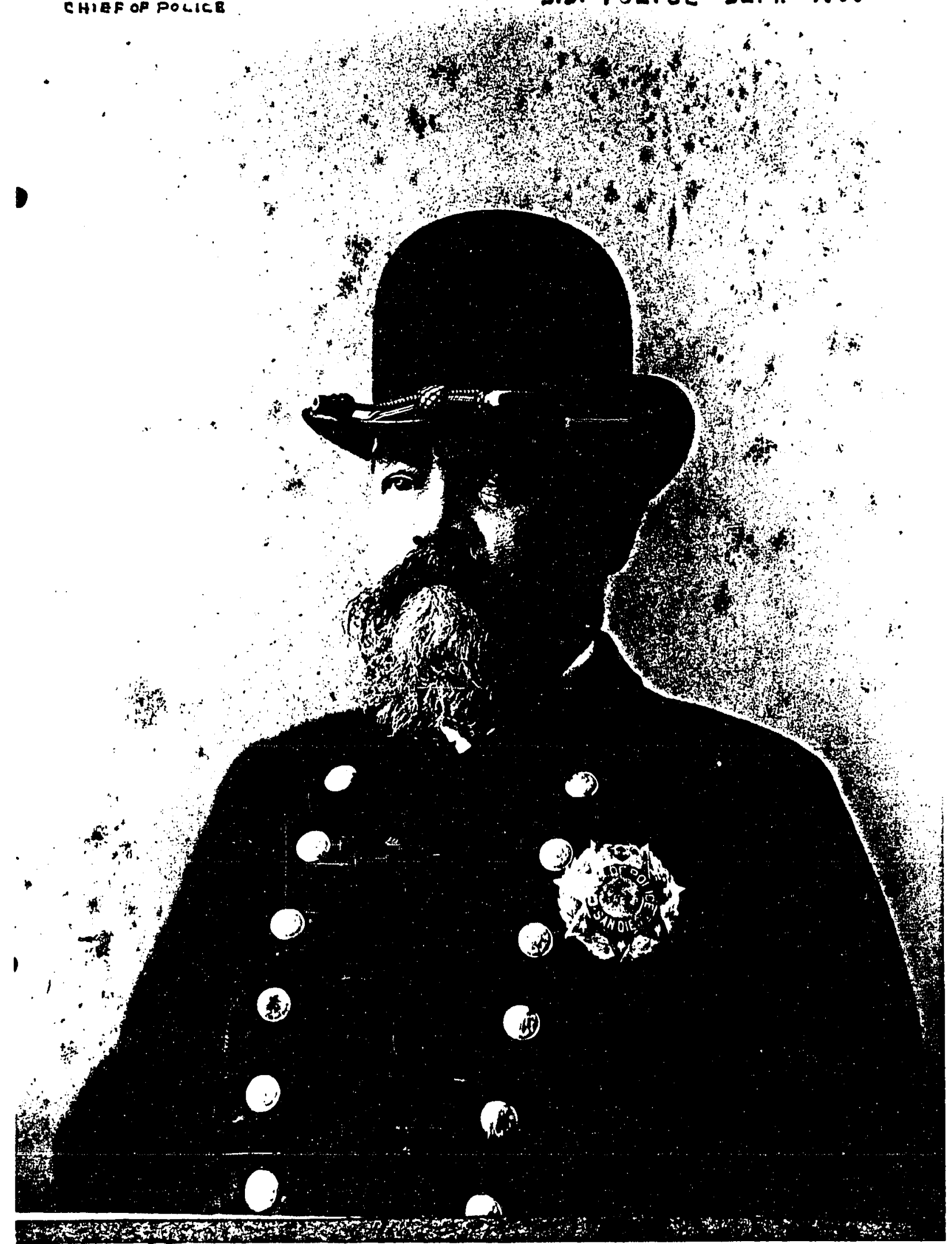


The Freeholder's Charter granted the peninsula (Coronado) to the City of San Diego in 1889 , and the law required that two years must elapse before the Charter could be amended. Coronadans objected to paying taxes to the City of San Diego and launched a campaign to form their own city. The segragation bill that Major Levi Chase was trying to push through the legislature would be of no effect, even if passed. This petition for segregation bore the names of more residents of San Diego than there were residents of Coronado Beach. This apparently justified the court in finally brushing all contrary considerations aside and simply ruling that the will of the people had been sufficiently shown, and Coronado thus won i s freedom. In 1890, Coronado Beach incorporated as a city.107 In April 1891, the Police Commissioners elected William H. Crawford, age forty-four, as their new Chief of Police. The Commissioners failed to reappoint Chief Joseph Coyne. The final vote showed: William Crawford with three votes and Joseph Coyne with only one vote. Chief William Crawford had been a captain with the Chicago Police Department and had police experience dating back to 1874. William Crawford resigned from the Chicago Police Department and moved to the Pacific Coast. He came to San Diego 
and worked as a deputy Marshall assigned out of Los Angeles, a job he resigned to become Chief of Police for San Diego. However, Chief William Crawford held the Office of the Chief for only three months. At a Police Board meeting, on July 29, 1891, the mayor had the clerk read Chief William Crawford's resignation, effective September 1, 1891. Chief William Crawford had been forced to resign because of the use and abuse of deadly force by officers acting under the color of authority. Although Chief William Crawford was in office for a very short time, he managed to negotiate and obtain, for his fourteen officers, a one-week annual vacation, and a day off each week. Chief William Crawford's officers had been working seven days a week for two years. 108

After Chief William Crawford resigned, the Board cast a vote for a new Chief of Police. The vote showed: William H. Pringle with four votes and G. C. Arnold with just one vote. William Pringle was the owner of a large ranch and other properties. However, no one had bothered to ask William Pringle if he wanted to run the police department. On August 25, 1891, the clerk read a message from William Pringle, thanking the Police Board for the honor of being selected to the position of the Chief of Police. But William declined to 
serve, giving his reason as his obligations to private business.109 Following William Pringle's declined nomination, the Police Commission nominated Officer Jacob Brenning as the third Chief of Police. Once the vote was cast, it showed an unanimous vote in Jacob Brenning's favor. The San Diego Union reported, "It was a wise and commendable move, not only because it promoted a man from the ranks, a precedent which might hereafter be followed without deviation."110

On August 28, 1891, when Chief Jacob Brenning took office, he had seven officers assigned to the Department. But in 1892, he was given three additional officers bringing his total to ten officers. At the end of 1893 , the commissioners increased the strength of the Police Department from ten to fifteen officers. Chief Jacob Brenning served as Chief of Police until May 9, 1897, when he resigned.111

The Police Commissioners acted quickly to replace Chief Jacob Brenning. They elected James Russell, age forty-four, as their fourth Chief of Police, on May 4, 1897. Chief James Russell had worked as a Deputy Marshall, Constable, Deputy Sheriff and Deputy U. S. Marshall prior to his appointment to Chief of Police. Once Chief James Russell settled into his new job, the interim acting Chief, Sergeant John 
McInnis resigned. John McInnis' resignation cleared the way for Chief James Russell to promote Officer José Cota to the rank of sergeant to replace John McInnis. The number one sergeant position was the second man in charge, taking over the police department when the Chief was absent or was unable to perform his duties.112 Chief James Russell, in the 1899 mayoral election, bet on the wrong person. Chief James Russell was opposed to Edwin M. Capps for Mayor. But, Edwin Capps won the Mayorial election. This marked the end of Chief James Russell's career as Chief of Police. Chief James Russell was not reappointed and was out on May 9,1899.

The Police Commissioners met to elect their new police chief for a two year term. The Commission unanimously elected Edward Wilkerson Bushyhead, at the age of sixty-seven, as their fifth Chief of Police. Edward Bushyhead, an American Indian, had helped found the San Diego Union. Bushyhead was a journalist, who had now turned lawman. On May 15, 1899, Edward Bushyhead met Chief James Russell in his office and took possession of the Office of the Chief of Police. Chief Edward Bushyhead was seventy years old when he left the Chief of Police position.

Albert A. Thomas was the successor to Chief Edward 
Bushyhead. The Commissioners appointed Albert Thomas, who had worked as a U. S. Customs inspector at the San Ysidro Port of Entry, as the sixth Chief of Police. Chief Albert Thomas served for two terms (1903-1907) as Chief of Police. During the 1907 mayoral elections, John F. Forward won the Mayor's race. It became clear that a new chief would be appointed. Mayor John Forward's administration appointed George W. Moulton as the seventh Chief of Police.

Chief George Moulton was not a legal resident of the city and because of the residency requirement, he could not take office. Consequently, the City Council passed an emergency ordinance, waving the residency requirement. That cleared the way for George Moulton to assume the position of the Chief of Police. Unfortunately, Chief George Moulton resigned after three months of his appointment, saying he had obtained a better paying job.113 When George Moulton resigned on September 3, 1907, Mayor John Forward appointed William T. Neely as the eighth Chief of Police.

Chief William Neely created a Detectives Division within the San Diego Police Department. Prior to 1907, uniformed officers would take the preliminary report, conduct the follow-up investigation, and complete the entire investigation from preliminary 
XVII.

San Diego Police Officers in front of the Police

Station on 1028 Second Avenue in 1900s. San

Diego Historical Society, Photograph Collection. 


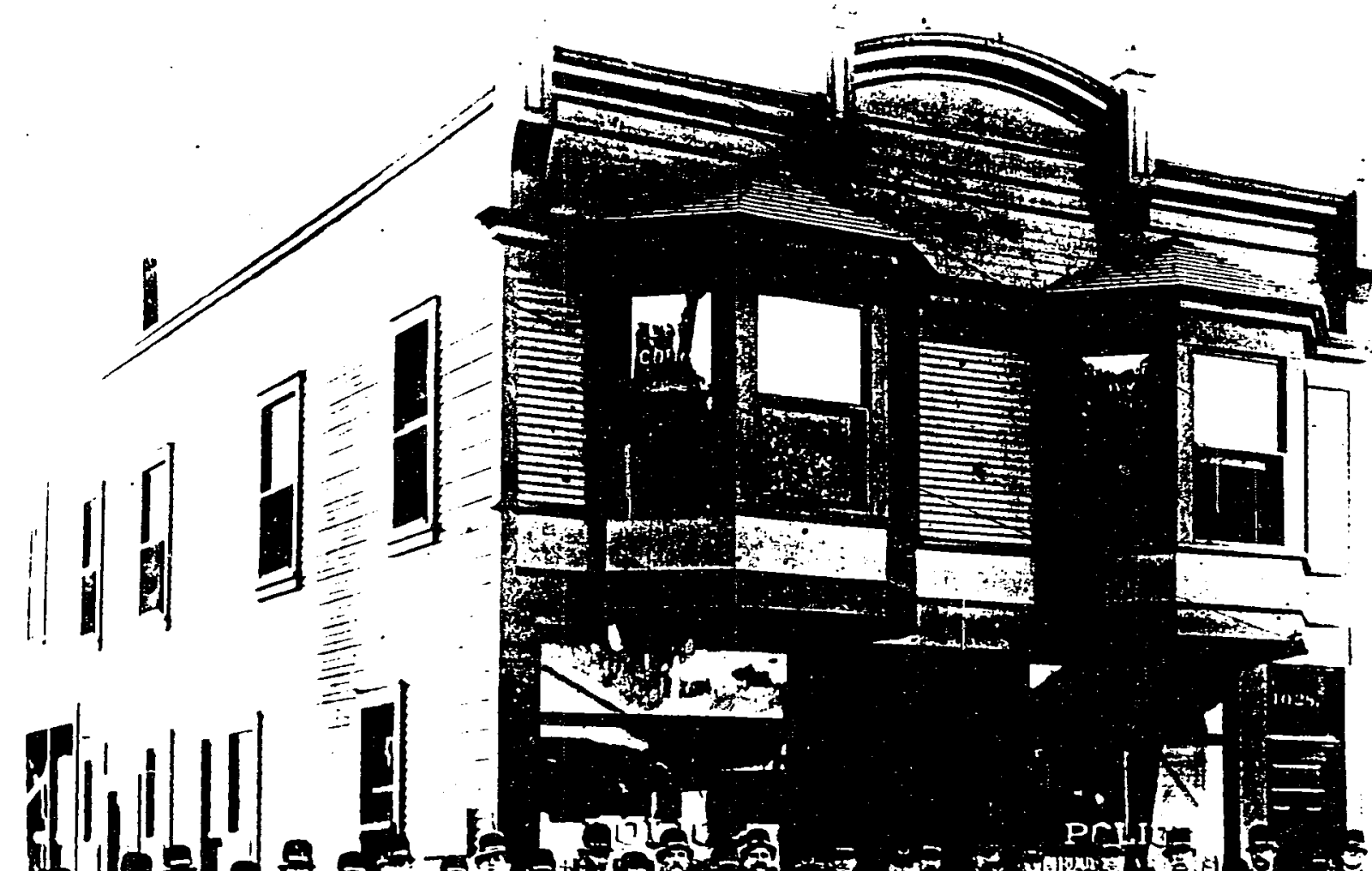

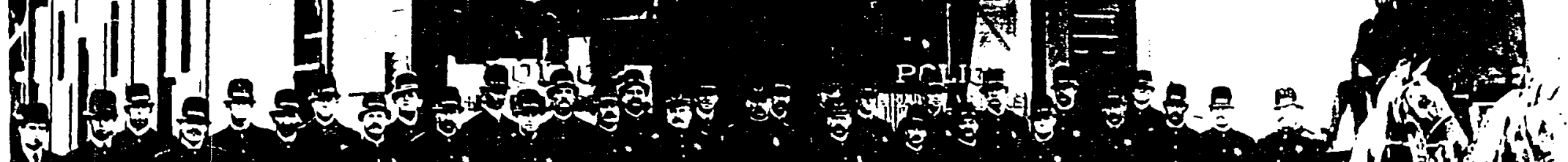
4.

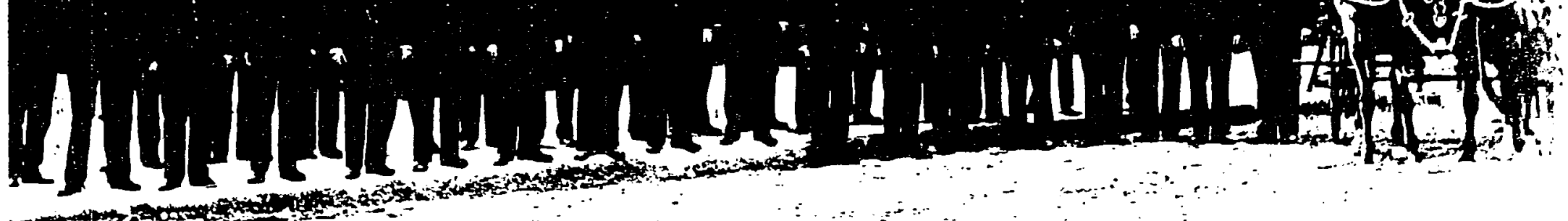

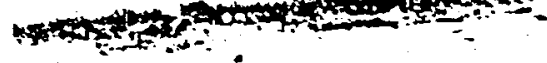

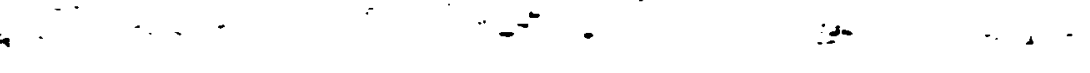


investigation to submission to the District Attorney's or City Attorney's Office for prosecution. Chief William Neely appointed Officer Harry Von Den Berg as the first detective for the San Diego Police Department. On May 30, 1909, Chief William Neely resigned from the San Diego Police Department and became County Building Inspector. William Neely supervised the construction of the County Jail, Balboa Stadium, and the Fine Arts Building in Balboa Park.114

During the 1880s, San Diego was exposed to gambling, liquor, and prostitution. One of the main goals of the Chief of Police, during that time, was to shut down some of the most notorious dance halis and gambling establishments. Toward the end of 1897 , the San Diego Police Department had 14 officers providing police service to a community of about 22,000 residents. 115 As time went on, the City of San Diego grew and so did the police department.

On May 3, 1909, the City Council appointed Jefferson “Keno" Wilson (1909-1917) as their ninth Chief of Police. Chief Jefferson Wilson was opposed to closing down the red light district. Chief Jefferson Wilson preferred to have the red light district where police could keep an eye on things. On November 10, 1912, however. because of political pressure, the Chief lead a raid in the red light 
district. At the conclusion of the raid, 138 women were arrested. Chief Jefferson Wilson claimed to have cleaned up the town, including the Oasis, which was located at the foot of Fourth, and the Turf, found at Fourth and "J" Streets, these were two of the most notorious dance halls during this period. 116

In June 1911, Antonio Gonzales, at 101 years of age, walked into Chief Jefferson Wilson's office and told him an interesting story. Antonio Gonzales produced convincing documentation to show that he was the first Hispanic Chief of Police for the San Diego Police Department. Antonio Gonzales' information was supported by Francisco Crosthwait, who was well known in early San Diego history. Antonio Gonzales claimed to have been the Chief of Police in 1847.117 In 1917, the City Council recognized that their police officers were untrained and wanted to prepare them for police work. Prior to 1940 , there was little or no formal police training. A rookie police officer would be assigned to a veteran officer for a couple of days for training. But there was no such thing as formal training. Police recruits being hired during that time had, perhaps, a grade-school education and no police experience. Many San Diego Police officers had been appointed because their relationship with the Chief of 

police in 1838. Gonzales was 101 years old when this photo was taken in 1911. San Diego Historical Society, Photograph Collection. 


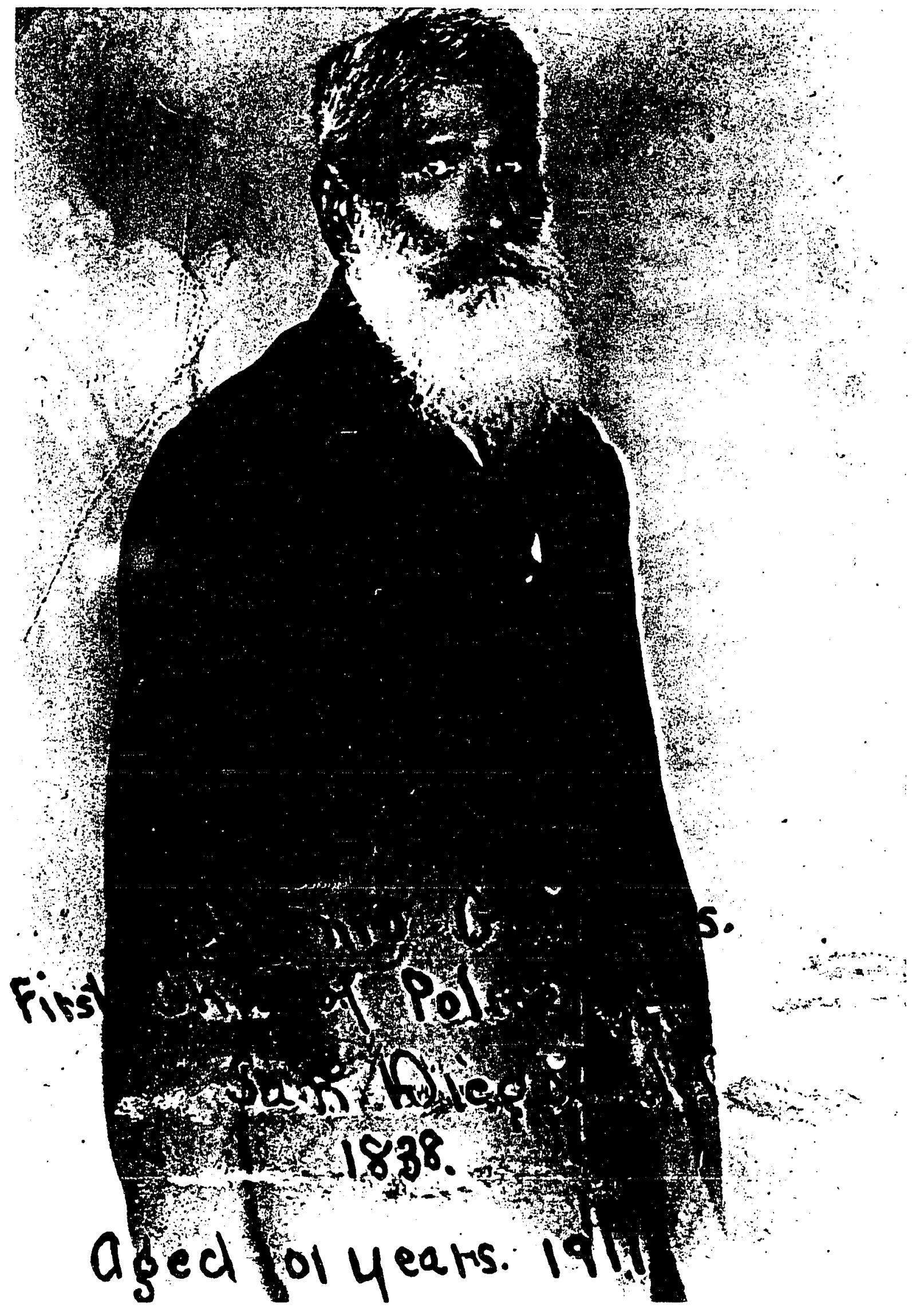


Police or some politician. 118

In order to study the problem of lack of formalized training, the City of San Diego hired August Vollmer, Chief of Police at Berkeley. Chief August Vollmer was asked to study the problem and make recommendations concerning training for San Diego police officers. After a two year study, Chief August Vollmer submitted his final report which included suggestions for subject matter and instruction methods for a formalized training program. This report was never implemented, except for the suggestion that the Police Department hire female officers, the report was stored in the city's files. 119

Between 1917 to 1934, the San Diego Police Department had 11 officers who served as Chief of Police. Most significant was the fact that between 1927 to 1934 , the City went through an average of one Chief of Police every 11 months. On April 7, 1931, the citizens of San Diego cast a vote in favor of a new city charter, one calling for the City Manager form of government, a charter which survives to the present day. This new City Manager system took control of the police department away from the Mayor and City Council and gave the appointment of Chief of Police to the City Manager. Although the 
City Manager was the person appointing the Chief of Police, the appointments were subject to approval by the City Council.120 In the 1930s, things began to change for the San Diego Police Department. The Depression had forced more qualified persons to seek employment in police work. Although the quality of police candidates had improved, they still lacked formal training. The City fathers kept prodding the chief to start a training program for his men (there were no female officers at the time).

On August 1, 1932, City Manager A. V. Goeddel appointed Robert Newsom as the eighteenth Chief of Police, making Robert Newsom the fourth chief of police in little more than a year. Chief Robert Newsom made efforts to start a training program, but before any program could get under way, Robert Newsom resigned as Chief of Police and returned to his former position as police captain.121

On September 7, 1934, George Sears was appointed as the twenty-first Chief of Police. But before Chief George Sears could implement any training program, other events got in the way. In 1935, the World's Exposition opened in Balboa Park, which required the hiring of additional officers. In addition, police equipment and programs were increasing: a) police radios were being installed in 
squad cars; b) the Traffic Division was increased in size; the school patrol program was started; c) a new police headquarters building was being planned; and d) many other improvements were being made within the department; however, no formal training academy was established. Although Chief George Sears had hoped to initiate a formal training program, political pressures forced him to retire.122 When Chief George Sears retired, City officials were left without a Chief of Police. The City Council considered police captains, lieutenants, and even sergeants, but none were acceptable--most of the candidates had been promoted under the old system-advancement by favoricism rather than by ability. The City went outside of the Department on a search for a new chief. The City of San Diego focused on a recommendation for Chief of Police from the Federal Bureau of Investigation (FBI). The FBI suggested police Lieutenant Clifford E. Peterson from the Long Beach Police Department. Lieutenant Clifford Peterson was a graduate from the FBI Academy, a Training Officer, and had a college degree. On March 16, 1940, the City hired Clifford Peterson as their twenty-third Chief of Police for the San Diego Police Department. Once in office, Chief Clifford Peterson was able to accomplish what the past chiefs had 
only tried, the creation of a formalized training program. 123

Officer Walter Scott had been on patrol when he heard a radio broadcast asking for anyone with typing skills to come into the station. Officer Walter Scott came in and was told that he would be transferred to the Identification Bureau. Officer Walter Scott had joined the San Diego Police Department on January 4, 1935, at the time, the police headquarters was located at 726 Second Avenue. When Chief Peterson was looking for an instructor for the new training program, he selected Officer Scott. Scott's background made him an ideal candidate as a training officer. Officer Scott's first class of 11 recruits was held in July of 1940 , following his graduation from the FBI Academy in June.124

On August 16, 1940, the Second Police Academy Class was created. This class consisted of six officers; Fred Christensen, Cody Isbell Sr., Orson Jones, Glenn Besnah, Elmer Wadman, and Harry Kemp. Of the six men in this class, five of them stayed, and made law enforcement their career--two were promoted to the rank of lieutenant and two to the rank of sergeant.125

Retired officer Bob Desch recalled his early days at the San Diego Police Academy. Bob Desch was a San Diego Police officer from 
April 1953 to October 1970, over 17 years of service. Officer Bob Desch recalled his academy day starting at 0800 hours and going to 1400 hours, Monday through Friday. After class he would walk a beat from 1800 hours to 2200 hours. There were no classes on Saturday or Sunday, so on those days, Bob would walk a beat. Officer Bob Desch was either in class, walking a beat or both, seven days a week, ten hours a day. 126

On May 1, 1958, Chuck Schilder joined the San Diego Police Department and, much like Bob Desch, Chuck Schilder's Academy curriculum consisted of four hours of classroom training followed by six hours of walking a beat. In a 1986 interview with Marce Hanson for the Informant, Chuck Schilder related a story following his assignment to the Northern Division (Old Firehouse on Herschel Street in La Jolla). Chuck Schilder was assigned to drive a 1956 Ford patrol car, but Chuck had no idea how to drive. Chuck Schilder was quoted as saying, "That's how much training I had-a policeman who had never driven a car with an automatic transmission."127

On October 16, 1947, Adam Elmer Jansen was appointed the twenty-fourth Chief of Police. Chief Adam Jansen named Wesley Sharp as his second in command. Chief Jansen made it clear that past 
abuse and dishonesty would not be tolerated. Chief Jansen moved the police department toward professionalism. He created a modern, comprehensive manual of operations, and updated the rules and operations of the department.128

During 1952 and 1953, the San Diego District Attorney, Donald Keller, and others, launched a program designed to restrict entry of unchaperoned individuals under the age of eighteen years of age into México. This program served to screen juveniles going into Tijuana, México, and turn back those juveniles who were unescorted by a parent or a guardian. Approximately 600 juveniles crossed the border into Tijuana each week without their parents. During this period, Tijuana had about 3,000 prostitutes, marijuana dealers were common, pornographic literature was readily available, and abortionists had agents who would seek customers at the border.129 The 1950 census reported the San Diego City's population at 334,387 residents.

In 1957, the San Diego Police Department opened a police check point at the San Ysidro/Tijuana border gate, in order to keep the unescorted juveniles from crossing into México.

Chief Adam Jansen served as Chief of Police from October 16, 
1947 to January 7, 1962. During his tenure, Chief Adam Jansen accomplished a number of goals for the San Diego Police Department; in 1949, the police school became an Academy; in 1950, he created the San Diego Police Reserve program; in July 1, 1954, he appointed four policewomen, the first since the mid-1920s; and in 1957, Chief Jansen established a police checkpoint at the San Ysidro/Tijuana border gate and a border police substation in the community of San Ysidro. In addition, Chief Jansen improved the liaison relationship with Tijuana law enforcement agencies by assigning an officer to work south of the border and serve as a liaison between the San Diego Police Department and Méxican law enforcement agencies. The addition improved the relationship of the San Diego Police Department and the Tijuana Police Department.130

\section{Summary}

This section of chapter two presented a brief discourse on the history of the cities of San Diego, San Ysidro, Tijuana, the San Ysidro/ Tijuana border region, and the San Diego Police Department.

The early history of San Diego presented the prehistoric, protohistoric, and historic periods. The prehistoric culture included the "San Dieguito Complex" 10,000 to 8,000 years B. P., the "La Jolla 
Complex" 9,000 to 8,500 B. P., and the Kumeyaay Indians, who moved to the western area of San Diego County some 2,000 years ago. During the historic period, Indians lived on the fringes of San Diego in what was called "rancherías" at times. As San Diego grew, Indians moved further east and south of San Diego. By the 1900, there were no "rancherías" left in San Diego.131

The protohistoric period included the Spanish Era, 1541 A. D., which saw Juan Rodriguez Cabrillo in September 1542, sail into San Diego Harbor. A second Spanish expedition saw Don Sebastian Vizcaino discover the same harbor that Cabrillo first discovered. The Hispanic Era, 1769 A. D., brought Father Junípero Serra to establish the Mission San Diego de Alcalá. The movement for independence from Spain by the people of México began as early as 1786 , but it was not significant until "El Grito de Dolores" in Chihuahua, México, in 1810 by Father Hidalgo del Castillo. The Méxican Era, 1821 A. D., brought México's independence from Spain. In addition, the Méxican government moved the capital from Monterey to San Diego. The Méxican government passed a law granting the acquisition of land by people occupying it. In 1829, Santiago Argüello was granted title to the "Ranchero de Tijuana."132 
During the 1900 s, the area on both sides of the border was called "Tijuana." In order to distinguish between the two Tijuanas, the town on the Méxican side was called "Old Tijuana." In 1925, the Méxican government changed the name of the City of Tijuana to Ciudad Zaragosa. This new name brought opposition from many residents and forced the Méxican government to change the town's name back to Tijuana, in 1929.133

The American Era, 1848 A. D., saw the end of the MéxicanAmerican War, which concluded with the signing of the Treaty of Guadalupe Hidalgo. Following this Treaty, the international border was established along the United States and México frontier. The resulting line cut diagonally across the Tijuana River Valley, leaving the mouth of the valley on the United States side and the narrowing upper part of the valley on the Méxican side. Thus the San DiegoTijuana international border was established.134

The City of San Diego had its inception on June 16, 1850, with the election of Joshua H. Bean as the first mayor of San Diego. On April 15, 1867, Alonzo E. Horton arrived in San Diego and purchased 960 acres of what is now Downtown San Diego. On April, 1872, much of Old Town San Diego was destroyed by fire. Many of the 
businesses relocated to the New San Diego area, what is now downtown San Diego.135

In 1908, William Smythe created a cooperative farming colony, which became known as the "Little Landers Colony," in the Tijuana River Valley.136 The objective of the Little Landers Colony was "to show families with little money and little or no farming experience just how they can get to the land without danger of going from bad to worse." 137 The original Little Landers Corporation was legally dissolved in November 30, 1912, for not paying franchise taxes.138

The Immigration Act of 1917 was created to restrict the flow of Méxican immigration. This law placed a "head tax" on Méxicans and also included a literacy examination which they were expected to fulfill. Late in 1917, the United States Immigration and Naturalization Department began to require a passport for people crossing the United States and México border. In December, 1917, the United States/México international border was closed to all traffic. The United States government reopened the international United States and México border in 1920.139

By the end of 1930, there were about 148,000 Méxicans living in the San Diego region. During the Great Depression, many 
immigrants and American-born Méxicans, more than 400,000 workers across the country, were arrested and deported.140

In 1957, the City of San Diego annexed the San Ysidro community, including Palm City, Nestor, and Otay Mesa. This annexation brought San Diego's city limits up to the international border.141 The San Ysidro-Tijuana Port of Entry is presently located six miles east from the Pacific Ocean and on the northern edge of the Tia Juana River Valley on the southwest facing slope of the Otay Mesa about 75 feet above sea level.142 In addition to the San Ysidro Port of Entry, San Diego now has a second Port of Entry located in the Otay Mesa, in South Bay.

The history of the San Diego Police Department may date back to May 16, 1889, at which time it was organized under "The Freeholders Charter."143 On April 1, 1850, Agustín Haraszthy was elected the first Sheriff of San Diego County.144 In 1863, Sheriff James McCoy was given the formal title of "Chief of Police," so that he could better protect the people from exposure to smallpox disease. In addition, Sheriff James McCoy was ordered to command all undesirable Indians and Méxicans, not employed, to leave town within 12 hours. 145 
Although the City of San Diego was established in 1850, it was not incorporated until 1888 , and established its police department on May 16, 1889.146 Joseph Coyne was elected as the first Chief of Police for the San Diego Police Department. Chief Coyne served from 1889 to 1891 . In April 1991, the Police Commissioners failed to reappoint Joseph Coyne as Chief of Police and elected William Crawford as their new Chief of Police. However, on July 29, 1891, Chief Crawford was forced to resign from the Police Department. After Chief Crawford's resignation, the Police Commission voted for William Pringle as their new Chief. Before William could take office, he declined his nomination, giving his reason as his obligations to his private business. William never took charge of the Police Department.147 On August 28, 1891, the Police Commission elected Officer Jacob Brenning as their third Chief of Police. Chief Jacob Brenning served as Chief of Police until May 9, 1897, when he resigned. 148

Following Chief Brenning's resignation, the Commission elected James Russell on May 4, 1897, as their new Chief of Police. On May 9, 1899, Chief Russell was not reappointed. Six days after Chief Russell resigned, Wilkerson Bushyhead was elected to replace him. 
In 1903, when Chief Bushyhead left the San Diego Police Department, he was seventy years old. Albert Thomas was appointed the successor to Chief Bushyhead and served for two terms as Chief of Police (1903 to 1907).

In 1907, John Forward won the Mayor's race and appointed George Moulton as the seventh Chief of Police. However, because George was not a legal resident of San Diego and the City had a residency requirement, he could not take office. The City waved the residency requirement, clearing the way for George to assume the Office of the Chief of Police. When George Moulton resigned on September 3, 1907, Mayor John Forward appointed William T. Neely as the eighth Chief of Police for the San Diego Police Department. On May 3, 1909, the City Council appointed Jefferson "Keno" Wilson (1909-1917) as their ninth Chief of Police.149

In June 1911, Antonio Gonzales, at 101 years of age, walked into Chief Jefferson Wilson's office and produced convincing documentation to show that he was the first Hispanic Chief of Police for the San Diego Police Department. Antonio Gonzales' information was supported by Francisco Crosthwait, who was well known in early San Diego history. Antonio Gonzales claimed to have been the Chief 
of Police during 1847.150

Between 1917 to 1934, the San Diego Police Department had 11 officers who served as Chief of Police. Most significantly was the fact that between 1927 to 1934 , the City went through an average of one Chief of Police every 11 months. On April 7, 1931, the citizens of San Diego cast a vote in favor of a new city charter, one calling for the City Manager form of government.151

On August 1, 1932, the City Manager appointed Robert Newsom as Chief of Police. Chief Newsom was the fourth Chief of Police in little more than a year. On September 7, 1934, George Sears was appointed as the Chief of Police. Although Chief George Sears had hoped to initiate a formal training program for the officers of the San Diego Police Department, he was forced to retire by political pressures. 152

When Chief Sears retired, the City went outside of the Police Department on search for a new Chief of Police. On March 16, 1940, the City hired Clifford Peterson as their twenty-third Chief of Police. Once in office, Chief Peterson was able to accomplish what the past chiefs had only tried, the creation of a formalized police training program. 153 
On October 16, 1947, Adam Elmer Jansen was appointed the twenty-fourth Chief of Police. He served from October 16, 1947 to January 7,1962 , and created a modern, comprehensive manual of operations, and updated the rules and operations of the San Diego Police Department.154 Chief Jansen improved the relationship between the San Diego Police Department and the Tijuana Municipal Police Department by creating the México Liaison position. Chief Jansen assigned an officer to work south of the border and assist the Méxican law enforcement agency with criminal investigations. This Unit now has a sergeant and two detectives working full-time as the México Liaison team.155 
XIX. Officer Jerry Martindale on the "call board" dispatching a radio call, c1954. San Diego Historical Society, Photograph Collection. 


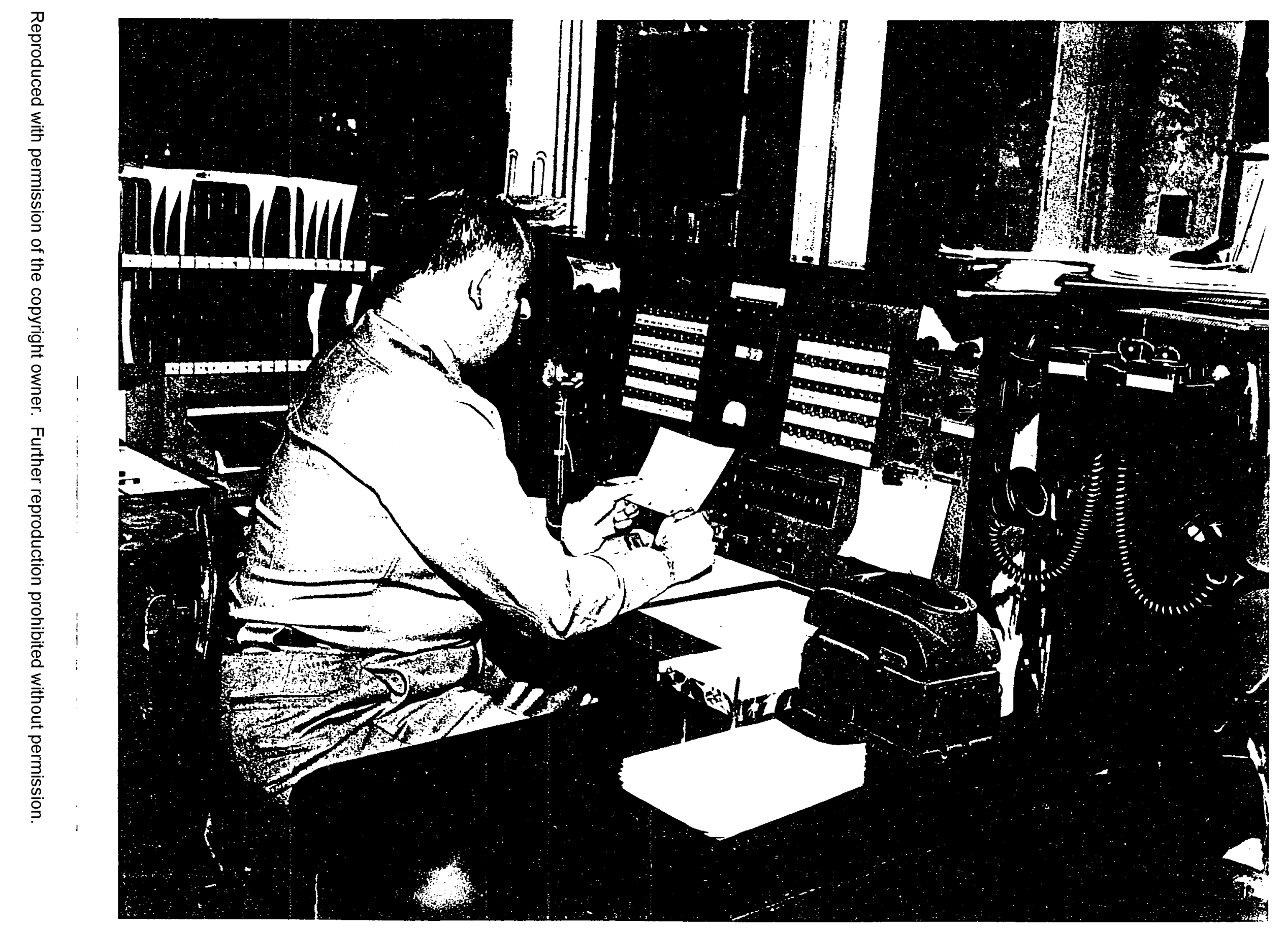


XX. Officer William Henry Harrison in a "Radio Car," 1954. San Diego Historical Society, Photograph Collection. 


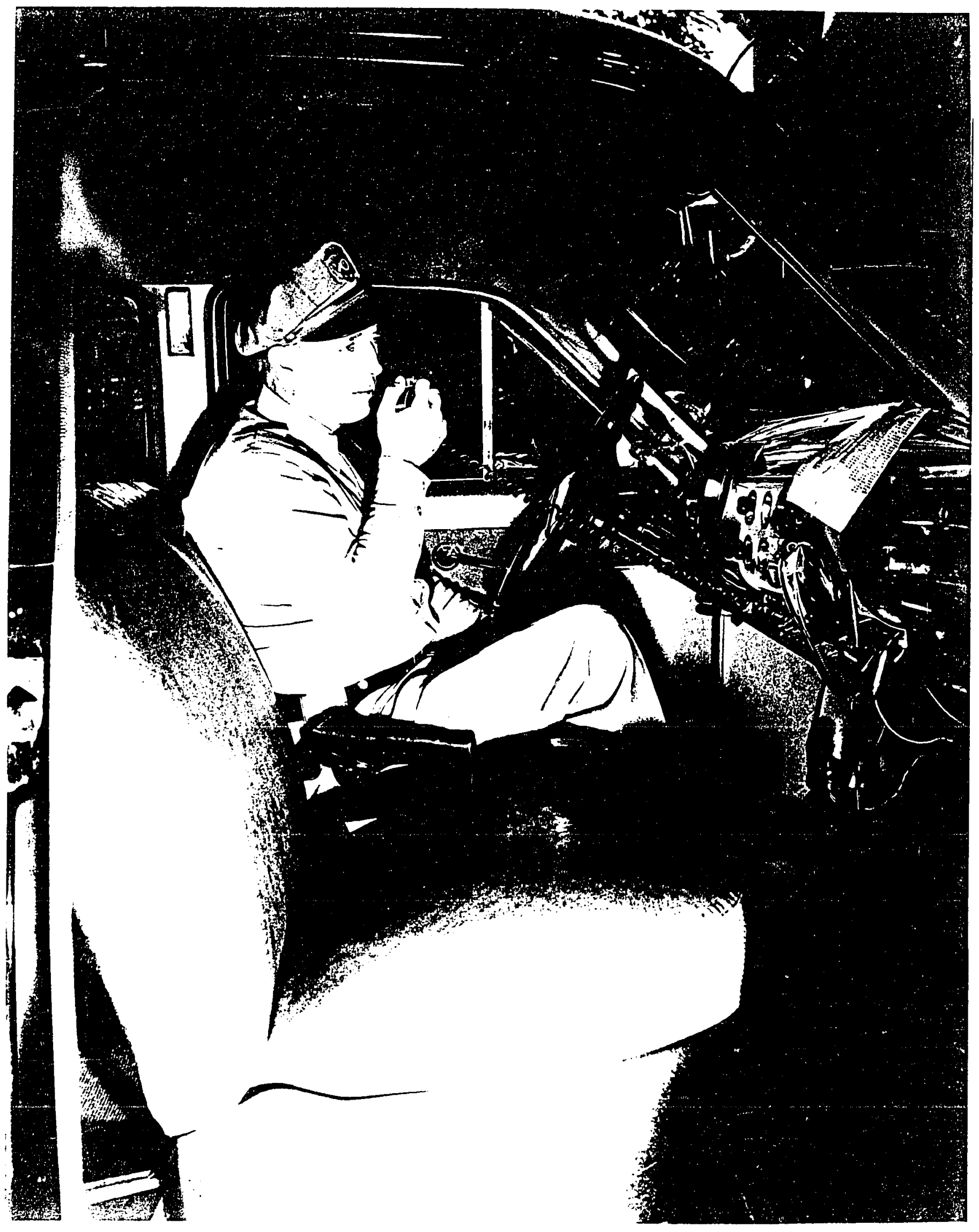




\title{
CHAPTER II
}

\author{
PART 1 \\ REVIEW OF THE LITERATURE
}

ENDNOTE

1. Malcolm J. Rogers. Ancient Hunters of the Far West. The Union Tribune Publishing Company (Ed.) with contributions by H. A. M. Worthington, E. L. Davis and C. W. Brock.

2. C. N. Warren, and D. L. True. The San Diego Complex and Its place in California Prehistory. UCLA Archaeology Survey Report, pp. 246-388; J. R. Moriarty III, Transitional Desert Place in San Diego County, California. Science, Vol. 155, No. 3762, pp. 553-556; and J. R. Moriarty, The Coast Diegueño, San Diego Historic Indians, Western Explorer 1(3), pp. 9-21, San Diego: Cabrillo Historical Society.

3. G. Shumway, C. Hubbs, \& J.R. Moriarty. Scripps Estates Site, San Diego, California: A La Jolla Site dated 5460 to 7370 years Before the Present. Annuals of the New York Academy of Sciences, Vol. 93. Article 3, pp. 97-132.

4. B. F. Smith \& J. R. Moriarty. The Archaeological Excavations at Site W-20. Environmental Impact Report on file at the City of San Diego, Environmental Quality Division, and at Brian F. Smith and Associates.

5. Ibid.

6. G. F. Carter. Pleistocene man at San Diego. Johns Hopkins Press: Baltimore, MD.

7. R. C. Carrico. Archaeological Survey of proposed development Site at 12901298 Prospect Street, La Jolla. Report on file with the City of San Diego.

8. S. H. Carrico. "Urban Indians in San Diego: 1850-1880." Masters Thesis, University of San Diego, 1983.

9. Records search provided by the Butler/Roach Group for the City of San Diego, 1994. A Confidential Report accompanied by maps reflecting all known prehistoric sites in the Tijuana River Valley.

10. William L. Schurz. (1959). The Manila Galleons. New York: E. P. Dutton. 
11. Hubert Howe Bancroft. History of California, 1542-1890. Vols. 18-24 in his Works. San Francisco: The History Company, 1884-1890.

12. Michael W. Mathis. Viscaíno and Spanish Expansion in the Pacific Ocean. San Francisco: California Historical Society, 1968.

13. Ibid.

14. Letter by Junípero Serra in "Two letters from the Old World," Pequod. University of San Diego, (Translated ) by Ray Brandes, Spring 1967, No. 2, pp. 25-36.

15. Ray Brandes (ed. and translator). The Costansó Narrative of the Portola Expedition: First chronicle of the Spanish Conquest of Alta California.

Newhall, California: Hogarth Press, 1972. Also see Ray Brandes, "Mission San Diego de Alcalá: Archaeological and Historical Discoveries," in Some Catholic Reminiscences for the United States Bicentennial. Edited Msgr. Francis J. Weber, Catholic Conference of California by the Knights of Columbus, 1976.

16. John A. Price, October 1968. A History of Tijuana: Border Town and Port-oftrade. San Diego State University.

17. C. A. Cardenas. (1955). Tijuana, Ensayo Monigrafico. Editorial style, México, D.F.

18. T. D. Proffitt III. (1994). Tijuana: The history of a Méxican metropolis. San Diego State University Press: CA. p. 37.

19. Price, op. cit., 2.

20. Ray Brandes. Report on the Historical Research-Old Town, San Diego, California-the period 1821-1874. For the State of California Parks and Recreation Division, 1974 , p. 350.

21. Proffitt, op. cit., 101.

22. Treaty of Guadalupe Hidalgo, Article V, as found in Peter Thomas Conmy, $A$ Centennial Evaluation of the Treaty of Guadalupe Hidalgo, 1848-1948. Oakland: Public Library, 1948, p. 28.

23. Price, op. cit., 3.

24. Henry Halleck. (1968). The Méxican War in Baja California. (Doyce Nunis, ed.). Los Angeles: Dawson's Books Shop.

25. The International Boundary and Water Commission, United States and México, Report revised October, 1990. Commissioner Narendra N. Gunaji, 
Secretary Manuel R. Ybarra; for México, Commissioner Arturo Herrera Solis, Acting Secretary José de Jesus Luevano Grano. The Treaty of 1848 refers to the Treaty of Guadalupe Hidalgo of Peace, Friendship, Limits and Settlement between the United States and México (TS 207; 9 Stat. 922; 18 Sta. (Pt. 2, Public Treaties) 492), and the Treaty of 1853 refers to the Treaty of December 30,1853 , relating to the boundary line, transit of person, etc., across the Isthums of Tehuantepec (TS 208; 10 Stat. 1031; 18 Stat. (Pt. 2, Public Treaties) 503).

26. The Star News, May 6, 1979.

27. Ibid.

28. Ibid.

29. Elizabeth C. McPhail. The Story of New San Diego and of its Founder Alonzo E. Horton. 2nd Edition revised. National City: San Diego Historical Society, 1979.

30. R. Brandes, J. R. Moriarty III, \& S. Carrico. History and Archaeology of New Town, San Diego, California. Published for Centre City Development Corporation, 1981 and 1985.

31. See Iris Engstrand. San Diego: Cornerstone of California. Continental Press Inc.: Oklahoma City, 1980, and Michael McKeever. A Short History of San Diego. Lexikos: San Francisco, CA., n. d.

32. Michael McKeever. (1985). A short history of San Diego. San Francisco: Lexikos. 38.

33. Ibid., 378.

34. Smythe, op. cit., 316-376.

35. William E. Smythe. History of San Diego, 1532-1908. Vol. I. San Diego Historical Society.

36. The California State Papers, extracts of which are in the Copley Library, obtained from the Bancroft Library, University of California at Berkeley, contain much detail about the process of law enforcement. It is worth noting that quite often peace officers often crossed the international Boundary line in pursuit of individuals who had committed criminal activities in San Diego. Individuals such as Cave Couts appeared in the court on charges, sometimes more than once, for allegations made against them. Two jail houses were located in Old Town. The first, a cobblestone jail was constructed in 1834-1835, within the placita, excavated by University of San Diego students in the 1970s, and the second, a cobblestone jail built about 1851, one mile south (off San Diego Avenue) in which the infamous jail break occurred when an inmate simply burrowed his way out. This had since been designated a City of San Diego Historical Site No. 46 (1970), located at 2360 San Diego Avenue and known as the "Cobblestone Jail" (Augustine Haraszthy Jail) Site. See the City 
Historical Site Board nomination.

37. Smythe, op. cit.

38. Ibid.

39. San Diego Union, January $26,1871,3$.

40. Herbert C. Hensley. "The memoirs of Herbert C. Hensley." "San Diego Historical Society--Serra Museum and Library, San Diego, California, Chapter 1, Vol. I, 7.

41. McKeever, op. cit., 75 .

42. Deane Coklin, 1967,86 .

43. Latino Future Scan. 1991, 12-13.

44. Kenneth C. Martis. (1970). "United States International land border crossings: San Ysidro, California." A Thesis for Master of Arts in Geography, for San Diego State College, 28.

45. The Evening Tribune, Sept. 26, 1936.

46. The San Diego Daily Sun, June 15, 1888.

47. Richard E. Lingenfelter. (1967). The rush of '89. Los Angeles: Dawson's.

48. United States Office of the Census, Twelfth Census of the United States, 1900, Part I, Population. Washington, D. C. Government Printing Office, 1901, clxxiv; United States Office of the Census, Thirteenth Census of the United States, 1910, vol. 1, Population. Washington, D. C. Government Printing Office, 1913, 781; United States Office of the Census, Fourteenth Census of the United States, 1920, vol. 2, Population. Washington, D. C. Government Printing Office, 1922, 693; United States Office of the Census, Fifteenth Census of the United States, 1930, vol. 3, Population. Washington, D. C. Government Printing Office, $1933,225$.

49. Rush, 1964, 201-202.

50. The Star News, Sunday, May 6, 1979.

51. Hensley, op. cit., 7.

52. Los Angeles Times, Nov. 12, 1987.

53. The Evening Tribune, Sept. 26, 1936.

54. The Evening Tribune, Sept. 26, 1936. 
55. San Diego Union, January 19, 1916.

56. Ibid.

57. San Diego Union, January 20, 1916.

58. San Diego Union, January 20, 1916.

59. Ibid.

60. The Evening Tribune, Sept. 26, 1936.

61. San Diego Independent, Aug. 28, 1955.

62. Imperial Beach Star News, Aug. 23, 1987.

63. Imperial Beach Reminder. Aug. 2, 1978. Staff writer Patty Emond.

64. Star News, Aug. 3, 1978. Staff write Mary Wood.

65. Imperial Beach Reminder. Aug. 2, 1978. Staff writer Patty Emond.

66. Martis, op. cit., 30.

67. Ethel Duffy Turner. (1981). Revolution in Baja California: Ricardo Flores Magon's High Noon. Detroit,MI.: Blaine Ethridge.

The Battle of Tijuana lasted from May 8, 1911 at 08:30 A.M. to May 9, 1911 at 09:40 A. M. Three companies of Liberals were involved. After the victory, store owners were allowed to reopen their shops, and Americans were granted permission to visit Tijuana.

68. United Way, op. cit., 12-15.

69. Roberta Ridgely. "The Man who built Tijuana," San Diego Magazine, Parts 1-10., March, 1966 - March, 1969.

70. San Diego Union, December 5, 1917, 1.

71. Ridgely, May, 1967, 78.

72. Ridgely, March, 1969, 88 .

73. U. S. News and World Report, 58, May 31, 1965, 73-75. 
74. Martis, op. cit., 20.

75. International Boundary Commission--Report of the United States and Méxican Boundary Commission 1882-1896. (Washington, D. C.: United States Government Printing Office, 1896), 197.

76. Martis, op. cit., 19.

77. California Border Alliance Group, Southwest Border. Information collected from the United States Customs. Information came from a confidential report (May 15, 1995) on the threat assessment of the border region.

78. California Border Alliance Group, Southwest Border. Information collected from the United States Customs. Information came from a confidential report (May 15, 1995) on the threat assessment of the border region. The tunnel was discovered during the investigation into the killing of a Méxican Catholic Cardinal, in Guadalajara airport. Some of the suspects were street gang members from Logan street gang in San Diego.

79. Ibid., 2.

80. Ibid.

81. San Diego Union, March 15, 1942, 6.

82. Daniel Wolf. (1988). Undocumented aliens and crime: The case od San Diego County. University of California at San Diego: San Diego, CA.

83. United States Department of Commerce, Economics and Statistics Administration Bureau of the Census. We the American. . . Hispanics. November 1993, 7. Latin America includes Hispanics who trace their origin or descent to Spain or to México, Puerto Rico, Cuba, and many other Spanishspeaking countries of Latin America.

84. San Diego Union, August 10, 1951, 1.

85. San Diego Union, November 24, 1963, 13.

86. Oscar J. Martinez. (1994). Border people. Tucson, AZ: The University of Arizona Press.

87. Lawrence A. Herzog. (1990). Where north meets south: Cities, space, and politics on the U.S. - México border. Center for Méxican American studies. University of Texas at Austin, 4.

88. Martinez, op. cit. 
89. Herzog, op. cit., 27-34.

90. Ibid., 34 .

91. Ibid., 36-38.

92. San Diego Evening Tribune. November 26, 1962. A-6.

93. Ibid.

94. Ibid.

95. Ibid.

96. Ibid.

97. Ibid.

98. Ibid.

99. San Diego Police Department Commemorative Album, 1889-1986. San Diego Police Officer's Association.

100. Thelma White, member of the Research Committee of the Historical Site Board of the City of San Diego, presented at a meeting of the Historical Site Board, July 10, 1970. Report on Agustin Haraszthy, first Sheriff of San Diego County.

101. Ibid., San Diego Historical Site Board register number 46, 2360 San Diego Avenue (Old Town), Block 509 (Zink map), name of site is Cobblestone Jail (Haraszthy Jail), a one story Cobblestone set in mortar without cement. Built by Agustin Haraszthy, first Sheriff of San Diego. The jail was partially destroyed by flood during construction, additional money was requested by Haraszthy in order to finish the jail. The jail was completed in 1851, and was used only once; the first prisoner held there escaped by digging through the walls.

102. Ibid., In the Spring of 1849 , Agustin Haraszthy came to San Diego with his father, wife, and six children. For centuries the Haraszthy family in Hungary had grown the grapes for the famous Tokay wines. Here they planted acres of grapes in the San Luis Rey and Mission Valleys.

In San Diego, pueblo lands were being distributed among eager buyers. Agustin Haraszthy was one of ten men who purchased a strip of 687 acres between Old Town and New Town for \$3,185.

Agustin Haraszthy and his family moved to Northern California where he is 
widely recognized as the founder of the California wine industry. Agustin disappeared in 1871 while visiting a plantation he owned in Nicaragua. It was concluded that he was eaten by crocodiles when he fell into a stream.

103. San Diego Tribune, October 4, 1839. The only Indian exempt from leaving town within the 12 hours was Alcals José Manuel and his family.

104. Elizabeth MacPhail, C. (1969). The story of New San Diego and of its founder Alonzo E. Horton. 97.

105. Castanien, Pliny. ((1993). To protect and serve: 1889-1989. San Diego Historical Society: San Diego, Ca. 4-8.

106. Ibid., 8.

107. Herbert Hensley. The Memoirs of Herbert Hensley:The History of San Diego, City, County, and region through the memories, anecdotes and recollections of Herbert Hensley. Collected and edited by Hensley over a three year period, 1949-1952. Vols. I-V. Deposited in the Archives of the San Diego Historical Society, October 6, 1952. Vol. IV. pp. 523-538.

108. Castanien, op. cit., 8-10. Chief William Crawford's policemen were prone to shoot without regard for the safety of bystanders. In addition, there was a conflict between AWOL sailors and members of the Marshall's Office. When it was all said and done, Chief William Crawford was held accountable for not stopping the Marshall "posse," which had clubbed to death a sailor. San Diego had always been a good liberty port for sailors and did not want to get the reputation of being a dangerous and unfriendly town. The Union and Hensley's Memoirs tell of these stories.

109. The mayor commented that William Pringle never qualified for the position, therefore the office of the chief of police was still vacant. For some reason Pringle has always been listed as the third chief of police. However, he was never sworn nor appointed. This researcher will not count Pringle as a chief of police in this report.

110. San Diego Union, August 25, 1891.

111. Castanien, op. cit., 10-12.

112. Jóse Cota was the first Hispanic police officers for the San Diego Police Department, more on this subject later under minority officers. Cota was appointed in 1897.

113. George W. Moulton after leaving his position of the Chief of Police, became the County assessor. As fate may have it, Moulton was arrested and sentenced to prison in 1931 for theft of $\$ 25,000$ in county founds. 
114. One of Neely's sons, Harry Neely, a retired Fire Department Captain, said in a 1978 interview with Castanien, that his father was not a politician. When his father had enough of the politics, he resigned.

115. Ibid., 9-16.

116. Ibid.

117. San Diego Police Department Commemorative Album, 1889-1986. San Diego Police Officer's Association.

118. Bob Karrow. "Training: Here's your badge and gun, now go be a policeman!" The Informant. Vol. 9, Issue 7, July 1989, 16-17. The official publication of the San Diego Police Officers Association. This article was written by Bob Karrow, retired police sergeant.

Ret. Sergeant Karrow was selected as one of the training instructors for the newly created police academy. The other instructor was Lieutenant Walter Scott, who was also in charge of the Crime Lab.

119. Ibid., 16.

120. Ibid. 52-55. Under the new city charter, the manager appointed the chief of police subject to approval from the council. But the appointment was indefinite; no longer would a chief of police be removed every two years with the elections of mayors or City Council members. The city manager could remove the chief of police, but all hearings involving the investigations of the reasons for removal had to be conducted by the council.

121. Ibid., 16-17. Chief Newsom resigned as chief because he could not stand the politics of the Chief's Office and did not want any part of it. A few years after returning to his prior assignment as captain, Captain Newsom suffered a heart attack and died while on the job.

122. Ibid., 16.

123. Ibid., 16. Chief Peterson immediately started a training program for new police officers. He selected Walter Scott as the trainer. Scott was a former high school principal and was sent to the FBI Academy before putting together his first class.

124. Edward Kenney. "Days gone by: The legendary Walter R. Scott. Pioneer in two fields." The Informant. Vol. 7, Issue 10. November, 1987, 19. The official publication of the San Diego Police Officers Association. By Edward Kenney.

Walter Scott was born in 1902 in Tollerberg, Colorado. He grew up on a farm but left to college. He became a teacher in 1927 and soon he was made principal of a school in Trumble, Nebraska. Chief Peterson selected Walter R. Scott was the instructor for the formal training program. Scott was promoted 
to sergeant on July 1, 1941 and lieutenant on July $1,1949$.

125. Edward Kenney. "Days gone by: Police training Class number 2- August 16, 1940." The Informant. Vol. VII. Issue 9, October, 1987, 21. The official publication of the San Diego Police Officers Association.

126. Bob Desch. "The good old, bad old days." The Informant. Vol. 6, issue 8. September, 1986, 33. The official publication of the San Diego Police Officers Association. Bob Desch retired in 1970 from the San Diego Police Department.

127. Marce Hanson. "Whatever happened to: Chuck Schilder worked Vice, Burglary, Special Investigations, and Homicide." The Informant. Vol. 6, issue 9. October, 1986, 20. The official publication of the San Diego Police Officers Association. Chuck retired after twenty-six years of service, as Captain, on March 19, 1984.

128. Castanien, op. cit., 77-79.

129. Price, op. cit., 10-11.

130. Ibid., 79-80.

131. R. C. Carrico and S. H. Carrico. "Urban Indians in San Diego: 1850-1880." Masters Thesis, University of San Diego, 1983.

132. John A. Price, op. cit.

133. Ibid., 2.

134. Ibid., 3.

135. McKeever, op. cit., 75.

136. The Evening Tribune, Sept. 26, 1936.

137. The Evening Tribune, Sept. 26, 1936.

138. San Diego Independent, Aug. 28, 1955.

139. San Diego Union, December 5, 1917, 1.

140. United Way, op. cit., 12-15.

141. Martis, op. cit, 20.

142. Ibid., 19.

143. San Diego Police Department Commemorative Album, 1889-1986. San

Diego Police Officer's Association. 
144. Thelma White, member of the Research Committee of the Historical Site Board of the City of San Diego, presented at a meeting of the Historical Site Board, July 10, 1970. Report on Agustín Haraszthy, first Sheriff of San Diego County.

145. San Diego Tribune, October 4, 1839. The only Indian exempt from leaving town within the 12 hours was Alcals José Manuel and his family.

146. Elizabeth C. MacPhail, op. cit.

147. The mayor commented that William Pringle never qualified for the position, therefore the office of the chief of police was still vacant. For some reason Pringle has always been listed as the third chief of police. However, he was never sworn nor appointed. This researcher will not count Pringle as a chief of police in this report.

148. Castanien, op. cit., 10-12.

149. Ibid.

150. San Diego Police Department Commemorative Album, 1889-1986. San Diego Police Officer's Association.

151. Ibid. 52-55. Under the new city charter, the manager appointed the chief of police subject to approval from the council. But the appointment was indefinite; no longer would a chief of police be removed every two years with the elections of mayors or City Council members. The city manager could remove the chief of police, but all hearings involving the investigations of the reasons for removal had to be conducted by the council.

152. Ibid., 16.

153. Ibid., 16. Chief Peterson immediately started a training program for new police officers. He selected Walter Scott as the trainer. Scott was a former high school principal and was sent to the FBI Academy before putting together his first class.

154. Castanien, op. cit., 77-79.

155. Ibid. 


\section{CHAPTER II}

PART 2

HISTORY OF SAN DIEGO POLICE DEPARTMENT, ITS ROLE AND

POLICIES ALONG THE SAN YSIDRO/TIJUANA BORDER

FROM 1957 to 1994

Within this chapter, the following subjects were discussed: The San Diego Police Department 1957-1994, minority and female officers within the San Diego Police Department 1878-1994, México's law enforcement Beta Group 1990-1994, and the United States Border Patrol 1904-1994.

San Diego Police Department: $1957-1994$

In 1957 , the San Diego Police Department established a check point at the entrance to Tijuana in order to keep juveniles without written permission from their parents or legal guardians from entering México.1

On October 30,1957, the Department began operating a oneman police car. These cars were equipped with a Scream-Master siren. The siren was mounted on the roof of the police cars. 2 The Southern Division was created in 1957 when the City of 
XXI. This photo was taken in the 1960s, of the Southern Division border check point. It was built by federal funds as the San Ysidro border inspection station. San Diego Historical Society, Photograph Collection . 


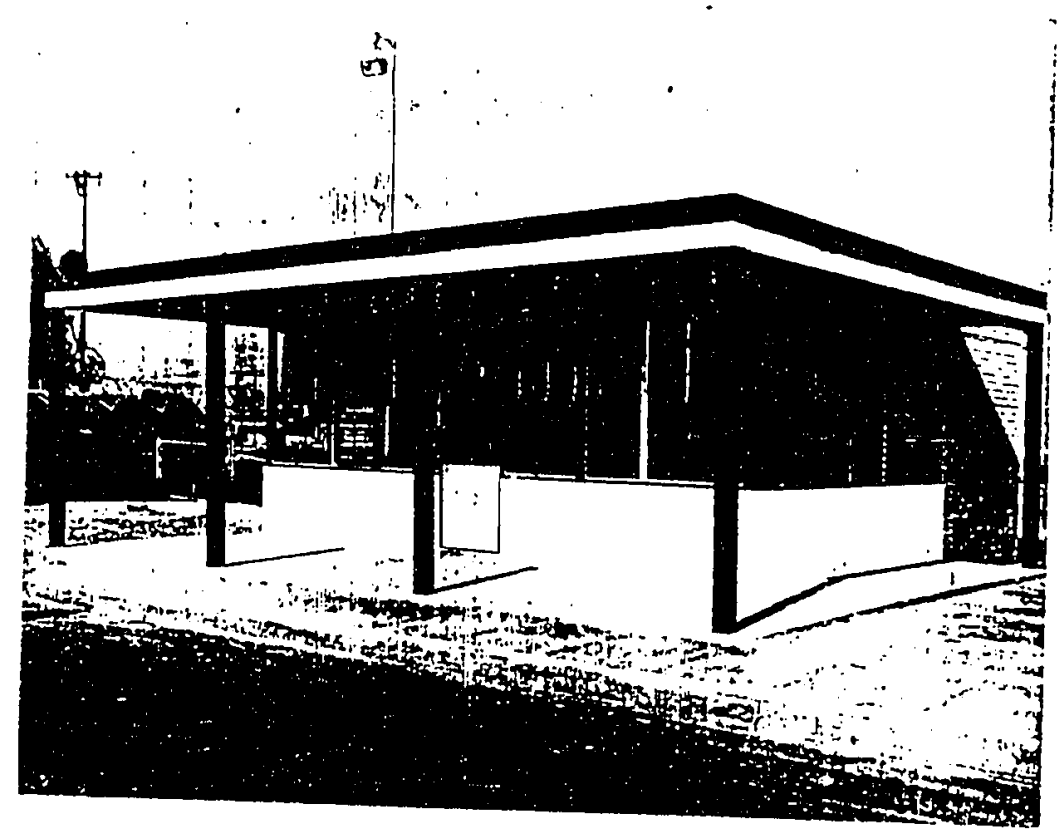


San Diego annexed twenty-two square miles along the international border, creating South San Diego. The police station provided space for one hundred officers and had a garage complete with full service. 3 During the first month of operation, the newly created substation made a record 527 arrests in the South Bay area. 4

The decentralized operation was instituted because of the isolated location of the region. Twenty-nine officers, including Captain Wayne Colburn, sergeants and three detectives, were assigned to the Southern Division. The patrol officers answered radio calls from the Central station, where all phone calls from the public were received. In order to keep the officers in the field at all times, officers from Central Division would meet the South Bay officers at a transfer point to pick up their prisoners and transport them to the City Jail.5 Chief Jansen hoped a new permanent substation could be provided with facilities for temporary jailing of prisoners. 6

Late in 1962, a new substation was build in San Ysidro for the Southern Division personnel at 663 Tijuana Boulevard, close to the international border. Chief Jansen reported that providing municipal police protection to a predominantly rural area and the policing of an international border was a new problem for the Department. He said 
that he would need more officers and equipment in order to satisfactorily handle the challenges in South Bay. Chief Jansen reported that the West Coast city average of policemen to population ratio was two officers for each 1,000 residents while in San Diego the ratio was only 1.3 policemen for each 1,000 residents. 7

Under the direction of Chief Jansen, Captain Gene Muehleisen created the Law Enforcement Code of Ethics document. This document first appeared in the 1960s and has been adopted by many law enforcement agencies across the nation and the California Peace Officer's Association. Another step toward professionalism was the decision of the San Diego Police Officer's Association to discontinue, after fifty years, the annual Policemen Ball. 8

Chief Jansen improved the working relationship with Tijuana law enforcement agencies by assigning an officer to work south of the border and serve as a liaison between the San Diego Police Department and Méxican law enforcement agencies. 9

The first officer assigned to the liaison position was Benny Wells. The liaison officer would assist the Méxican law enforcement agencies with criminal investigations concerning United States victims or suspects. In addition, the California Highway Patrol used 
to assist México with stolen vehicle investigations. However, when the Highway Patrol left México, the San Diego Police México liaison officer was asked to assume the duties once held by the Highway Patrol. After Wells left the México liaison position, the Department assigned Officer Al Gayton. As time when on other officers performed these duties. Some of the other México liaison officers were, Bob Trevino, Art Palmer, Ted Armijo, Ron Collins, Joe Navarro, Manny Smith, Jorge Navarro, and more recently, the México liaison position increased to include a sergeant and two officers. In 1994, Sergeant Vincent Villalvazo and Officers Art Cavada, Jesus Cesena, and Fausto Gonzalez worked as the México liaison officers.10

In January 1962, Chief Adam Jansen retired after serving twenty-nine years and ten months. On January 8, 1962, former Chief Adam Jansen was appointed as the Sheriff of San Diego County for an unexpired term. Jansen succeeded Sheriff Bert Strand, seventy years of age, who had served the County of San Diego for nearly twenty years. 11

On January 8, 1962, Wesley S. Sharp, was sixty-four years old when he was appointed as the twenty-fifth Chief of Police (January 8, 1962 to January 3, 1968). When Chief Wesley Sharp took office, 
the Department had 692 sworn officers and 128 civilians. The City's population was climbing at $600,000.12$

Chief Wesley Sharp recognized the need to improve police/ community relations, and assigned a captain to study the feasibility of establishing a community relations program. The program was created and by 1964 all officers were encouraged to assist in the new program. Lieutenant Homer Johnson and Sergeant Bill Kolender were the first full-time officers assigned to the community relations program. These officers visited universities, colleges, and secondary schools to explain law enforcement theories and concepts. 13

On May 15, 1966, Chief Wesley Sharp marked his thirty-fifth year of service at the age of sixty-seven. Because employees over the age of sixty-five required the approval and renewal from the City Manager, Chief Wesley Sharp was given a written renewal automatically by City Manager Tom Fletcher.14

During this period, the appearance of street officers changed. Chief Sharp allowed officers to wear short-sleeved shirts between July 1 through October 31. Patrol officers and sergeants were required to wear the safety helmets at all times instead of the soft caps.15 In July 1967, Chief Wesley Sharp organized the Internal 
Affairs Investigations Unit. The Department did not have a particular system for keeping records of complaints concerning officers' misconduct and violations of Department's policies. 16

In February 1965, Chief Sharp was responsible for bringing the computer technology to the San Diego Police Department. Prior to the implementation of the computer system, all criminal records had been recorded on punched cards. Chief Wesley Sharp assigned a lieutenant, a sergeant, and a patrol officer to the Records Bureau. These officers conducted a study and reported that the computer could be used in research, planning, field operations, traffic citations, and record systems. 17

Chief Wesley Sharp retired on January 2, 1968. Wesley Sharp remained active in the community and with civic affairs after his retirement. On December 3, 1991, Chief Wesley Sharp passed away in a San Diego convalescent home. 18

On January 4, 1968, Olif "Jimmy" Roed, forty-eight years of age, was appointed as the twenty-sixth Chief of Police. Chief Roed obtained authorization to increase the size of his department from 835 sworn officers to 1,028 , a $19 \%$ increase. Chief Roed made significant changes within the Police Department. One of his 
contributions was to change the color of the police cars. Chief Roed said, "We are changing to all-white, but distinctively marked, police cars for several reasons. Primarily, we have a maintenance problem with the black cars with white door panels. They have to be washed almost daily to look clean. With the all-white cars, we figure we can cut the washing maintenance in half." 19

The last three years of Chief Roed's career, he served as Chief of Police. Chief Roed spent 29 years and four months serving the citizens of San Diego. Chief Olif Roed was credited with initiating several programs during his tenure, such as: the advance officer inservice training program; store-front community relations program; an all-day police officer's conference in which police officers discussed problems and suggested improvements in Department operations; and a fleet safety driving program.20

With the closure of the San Diego Police Department's City Jail and the opening of the San Diego County Jail by accepting all city prisoners, the San Diego Police officers that had been serving as jailers were reassigned to other duties around the City.21

On March 11, 1971, Ray Hoobler, forty-three years of age, was appointed as the twenty-seventh Chief of Police. Chief Ray Hoobler's 
mission statement read as follows:

"The goal is to contribute to the highest quality of life in maintaining a peaceful and orderly community." 22

Chief Hoobler eliminated the mandatory wearing of the police safety helmet, which had been required since the late 1960s. During this period, the City decided to include paramedics in their ambulance program. The City Council took the service away from the San Diego Police Department and gave it to private paramedic/ ambulance operators under contract with the City. Prior to this move, the Police Department had operated seventeen station wagons converted to ambulances throughout the city. 23

In 1971, when Chief Hoobler took office, the budget was $\$ 15$ million dollars with 995 sworn officers. In 1975, the budget increased to $\$ 23$ million dollars with 1,200 sworn officers. 24

In October 1973, Chief Hoobler created the San Diego Narcotics Task Force (NTF). This task force consisted of three primary agencies; the San Diego Police Department, the San Diego Sheriff's Office, and the Federal Drug Enforcement Administration (DEA). Later NTF was expanded to include other police departments in the County. The Narcotics Task Force's objective was to coordinate 
narcotic enforcement in order to prevent duplication of effort.25

On July 17, 1975, the San Diego Police Department closed the juvenile check point, it had operated since 1957 at the San Ysidro/ Tijuana international border. Sergeant Ed Smith, one of the check point's supervisors, reported that the check point did more than just turn back juveniles. Ed Smith said his officers recovered a large number of stolen vehicles each year and they also arrested a large number of people who were wanted felons or had outstanding traffic warrants. 26

On February 13, 1976, Bill Kolender was confirmed as the twenty-eighth Chief of Police for the City of San Diego. This was the first public confirmation hearing for a chief of police in the history of the City of San Diego. Chief Kolender was forty years old when he was first appointed acting Chief after Chief Ray Hoobler resigned on September 9, 1975.27

Chief Kolender established a border task force, along the international border at San Ysidro, headed by Lieutenant Dick Snider. The purpose of this task force was to provide police service along the United States and México border within the city limits. The Border Alien Robbery Task Force (BARF), as the task force was known, was 
created in 1976 but abolished two years later. During the tenure of the BARF Team, officers were involved in seven officer involvedshooting which resulted in the wounding of three BARF members and the wounding of seven Méxican Nationals.28

On September 19, 1988, Robert W. Burgreen, forty-nine, was appointed twenty-ninth Chief of Police, after serving two months as acting chief.29 Chief Burgreen supported the México Liaison Unit and the Border Crime Prevention Unit (BCPU).30 In a 1993 interview with The Informant, former Chief Bob Burgreen recalled his accomplishments as the “top-cop." Chief Burgreen's goals which were successful included: the Neighborhood Policing Program; officer safety and options to the use of deadly force; and he managed to work within a restricted budget. 31

On May 17, 1993, Jerry Sanders was appointed as the thirtieth Chief of Police.32 Chief Sanders, 42 years of age, was sworn into office by Deputy Mayor Tom Behr after the San Diego City Council unanimously confirmed his appointment. Before the City Council cast its vote, community residents, law enforcement officials, and council members praised Chief Jerry Sanders. Representatives of the Asian, Filipino, African-American, and Hispanic groups also praised Chief 
Jerry Sanders. 33

Chief Jerry Sanders reported, to the council, that he would make changes to enhance the Neighborhood Policing efforts. Officers would be assigned to patrol particular communities rather than beats that cross traditional neighborhood boundaries. In addition, beats would be identified by community names and not by numbers, as they had been. Chief Jerry Sanders said the Department would work closely with diverse interest groups to determine to what extent its officers should cooperate with the United States Border Patrol in dealing with undocumented migrants. 34

In June 1993, Chief Sanders established the Neighborhood Policing Restructuring project for the purpose of developing a plan to realign the beat system as he had promised during his confirmation. This project had four main goals: 1) to develop a plan to convert a beat system, based primarily on the census tract as to one that was community based; 2) to incorporate problem solving procedures into all levels of the Department, and to all Department functions; 3) to reduce or eliminate any friction or gulf between the Neighborhood Policing Teams and regular patrol; and to develop a team policing structure for all patrol forces. 35 
The "Steering Committee" for the Restructuring Project, conducted a series of "Community Mapping" meetings to identify the specific communities around which to construct the new service areas. As part of their research, committee members reviewed maps of the area, held numerous community meetings in order to get input from the community, conducted site visits to outside agencies, and also telephone and mail surveys. These strategies were used in order to gather data on alternate staffing practices, beat structures, and service delivery systems. As a result of their intense research and deliberations, the committee members developed 42 recommendations for the Chief of Police. 36

The major recommendations that affected the border area were: the beat system restructuring and the undocumented person policy. The Southern Division beats were restructed into the $710 \mathrm{~s}$ and 720 s service areas, with one patrol lieutenant assigned to each service area on a 24 hour responsibility basis for managing all area police services. Each service area was staffed by patrol and detective teams, with the detectives working as generalists except for the auto theft and juvenile functions. The South Bay area of Southern Division was restructured as follows: 710 s area of responsibility included the 
Tijuana River Valley and the San Ysidro area. This service area received 10,500 calls for service with a population of about 23,388 . This area included the San Ysidro Port of Entry and the International Border region. The second service area for Southern Division was the communities of Egger Highlands, Nestor, Otay Mesa West, Palm City, and Otay Mesa - the secondary Port of Entry at Otay Mesa. This service area had 19,000 calls of service with a population of about 63,326 residents for a total population for both service areas of 86 , 714 residents. 37

The undocumented person policy was changed, with input from community leaders, in order to allow the officers the flexibility to handle the criminal alien. There will be more on this topic in another section within this chapter.

Under Chief Sanders, the Border Crime Intervention Unit (BCIU) continued to work along the border. The methods of operations for BCIU continued the collaboration with a Méxican law enforcement task force known as the "Grupo Beta" (Beta group).38 The U.S. Border Patrol agents used to refer to the Beta Group officers as "Bandit-one or Bandit-two." But the Méxican law enforcement officials did not like being referred to as bandits, so they shortened the name of 
Bandit to "B" or BETA.39

Minority and Females Officers: $1878-1994$

Although the San Diego Police Department has officers within its ranks from various ethnic backgrounds, this section focused primarily on the most documented groups; African-American, Hispanics, and women. That is not to say or insinuate that the other groups are not as important, because they are. It was just simply a matter of time constraint and data collection.

\section{African-Americans}

The first full-time sworn African-American police officer on record, with the San Diego Police Department was Reginald S. Townsend. Officer Townsend was hired on January 1, 1915.40

On March 1, 1918, another African-American Officer, named John Cloud, made police work his career. Officer Cloud gave the City of San Diego and the San Diego Police Department 22 years of his life. Officer Cloud retired from the Police Department on March 31, 1938.41

Officer Jasper A. Davis also decided to make law enforcement his career and joined the San Diego Police Department on March 2, 1931. Officer Davis worked in the field and as a radio dispatcher 
before retiring in the early 1950's.42

In May 1936, another African-American officer, Bert Ritchey, joined the San Diego Police Department after having worked as a temporary policeman in San Diego during the 1935 California Exposition in Balboa Park.43 Officer Ritchey brought several innovations to the police department, for example; he pioneered the establishment and development of the San Diego Police Department's Laboratory. Prior to 1942, the Department was limited in its ability to analyze physical evidence. Officer Ritchey's background was in chemistry. Consequently, Officer Ritchey was able to obtain laboratory equipment from a friend and soon he and others in the Identification Bureau (Records), established a crime laboratory. The crime laboratory passed its first court test when Officer Bert Ritchey, using scientific methods, broke a homicide case. The homicide case involved the husband of a murdered victim, who alleged that his wife had been strangled by an intruder. The suspect, allegedly, had gained entry into the house by tearing a screen door. The intruder then reached through and opened the inside latch. During the investigation, officers seized the door as evidence. Officer Ritchey carefully examined the evidence and concluded that the screen had 
been torn from the inside and that no forced entry had been made. Officer Ritchey later testified in court and the jury convicted the husband of first degree murder. 44

On September 3, 1957, Sam Edmonds joined the San Diego Police Department as a police recruit. Officer Sam Edmonds worked as a patrolman and later as a traffic accident investigator. Sam applied for motorcycle duty in 1962 and was placed at the top of the eligibility list. In July 1963, Officer Sam Edmonds was appointed to the motorcycle squad, as the first African-American officer in that position. 45

By 1994, African-Americans officers had obtained ranking positions within the San Diego Police Department: Assistant Chief Rulette Armstead, the first African-American to reach this position; Captain Alton Williams, and Lieutenants Howard Kendall, Harold Cox, Mike Gillespie, and Marvin Maxwell.

At the end of 1994, there were a number of African-American sworn officers who had made police work their career. The San Diego Police Department Personnel Division showed the following: one Assistant Chief of Police, one captain, 23 sergeants or lieutenants, and 127 officers, agents, or detectives. 46 
XXII. Sam Edmonds, first African-American officer assigned to motorcycle duty in the history of the San Diego Police Department, July 15, 1963. Photo courtesy of Tribune file photo. 


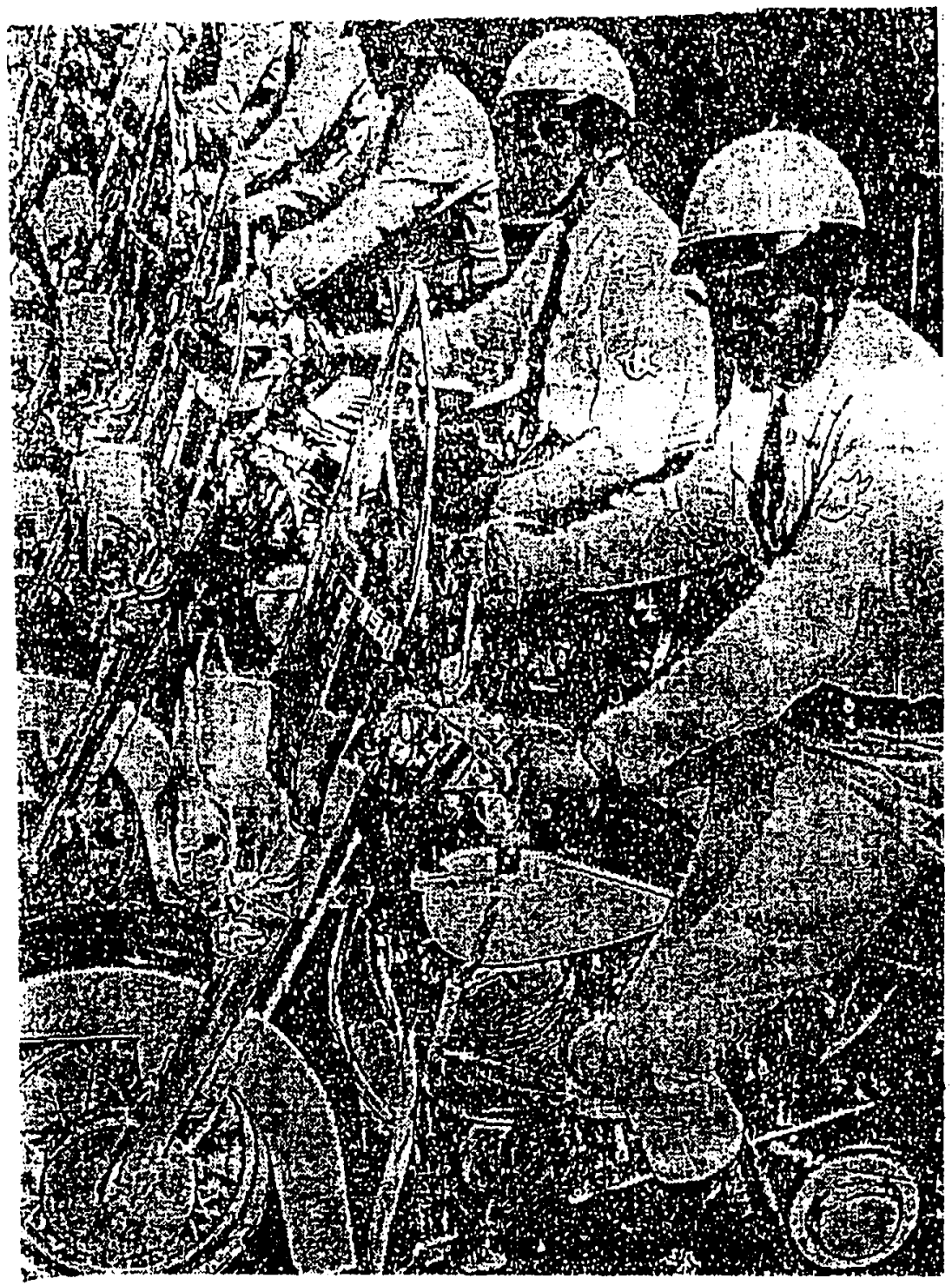




\section{Hispanic/Latino Officers}

José Cota testified in court in 1892 , that he had been a police officer for 14 years, which dated back to 1878 . José had been a constable and came to San Diego Police (Metro) about 1890.47

Another Hispanic officer hired by the San Diego Police Department was Joseph A. López. Chief Jefferson "Keno" Wilson appointed López as policeman on November 20, 1918. Officer López worked in the Detective Bureau as a detective, as a detective sergeant, and later as a detective lieutenant. Lieutenant Joseph López retired in 1936.48

In 1989, Samuel Walker, Professor of Criminal Justice at the University of Nebraska at Omaha, conducted a five year study into the employment of African-American and Hispanic police officers in 50 large cities in the United States. Ninety-four percent ( 47 police departments) of the total responded to the survey. The survey collected data on the total number of sworn police officers, the number of African-American and Hispanic officers in each police department. The survey did not collect data on the racial ethnicity of officers at different ranks within each of the police departments.

Professor Samuel Walker created an index to measure the 
XXIII. This is an $\mathbf{1 8 9 0}$ portrait of Officer José Cota, who was one of the first Hispanic officers in the San Diego Police Department. San Diego Historical Society, Photograph Collection. 


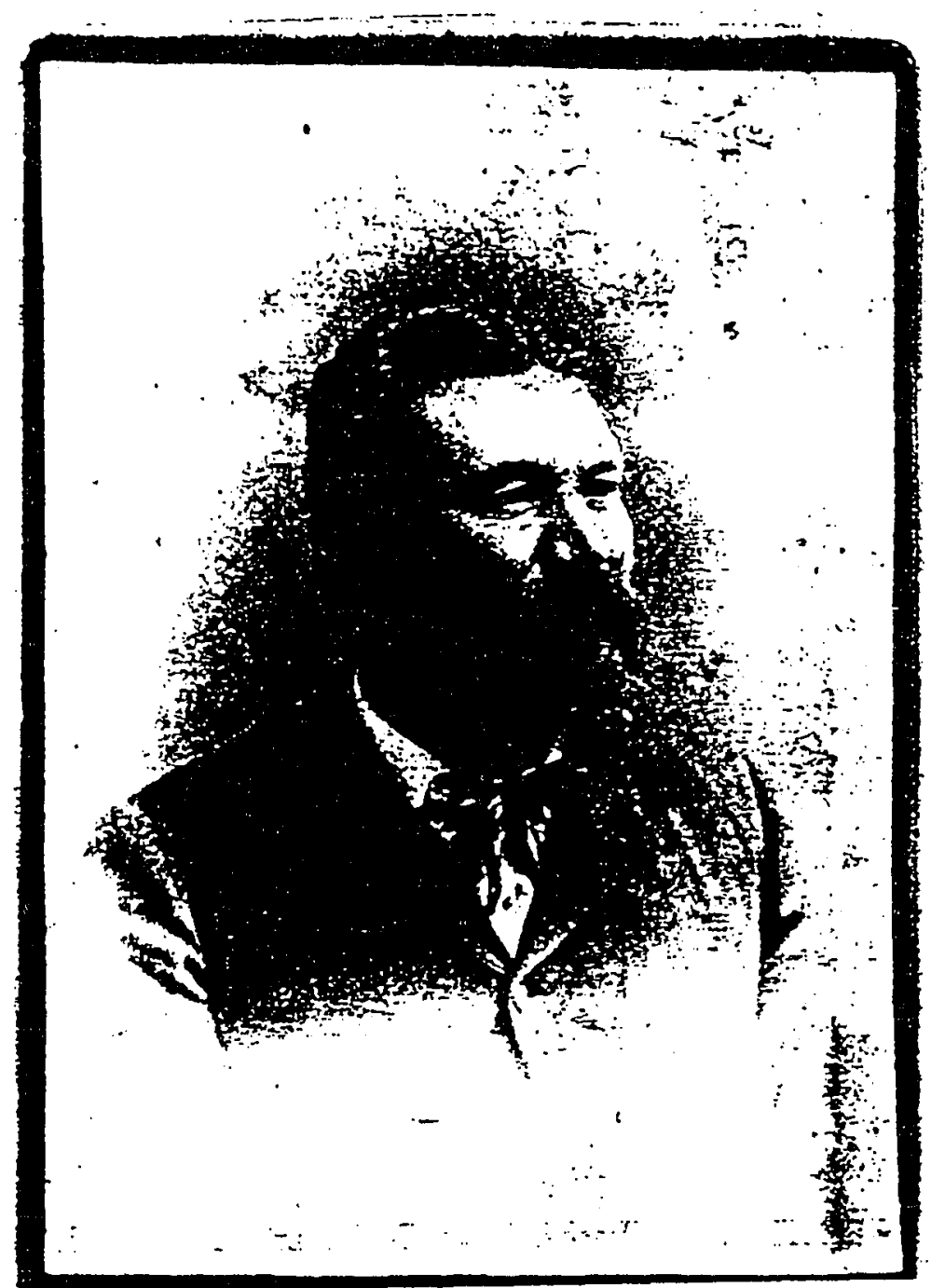


percentage of minorities employed relative to the percentage of minorities in the local population. He established a theoretical ideal level of minority employment when the employed percentage equals the percentage of that minority group in the local population, yielding an index of 1.0 percent. 49

In 1983, three law enforcement agencies had an index of .75 for African-American officers; by 1988 there were 11 police departments, nationwide, with the .75 index level. In 1983, eight law enforcement agencies had an index of .75 of Hispanic police officers; by 1988 the total number of police departments with an index of .75 of Hispanic police officers had increased to 16.50

In San Diego, the numbers for these two categories, AfricanAmerican and Hispanic police officers, ranked as follows:

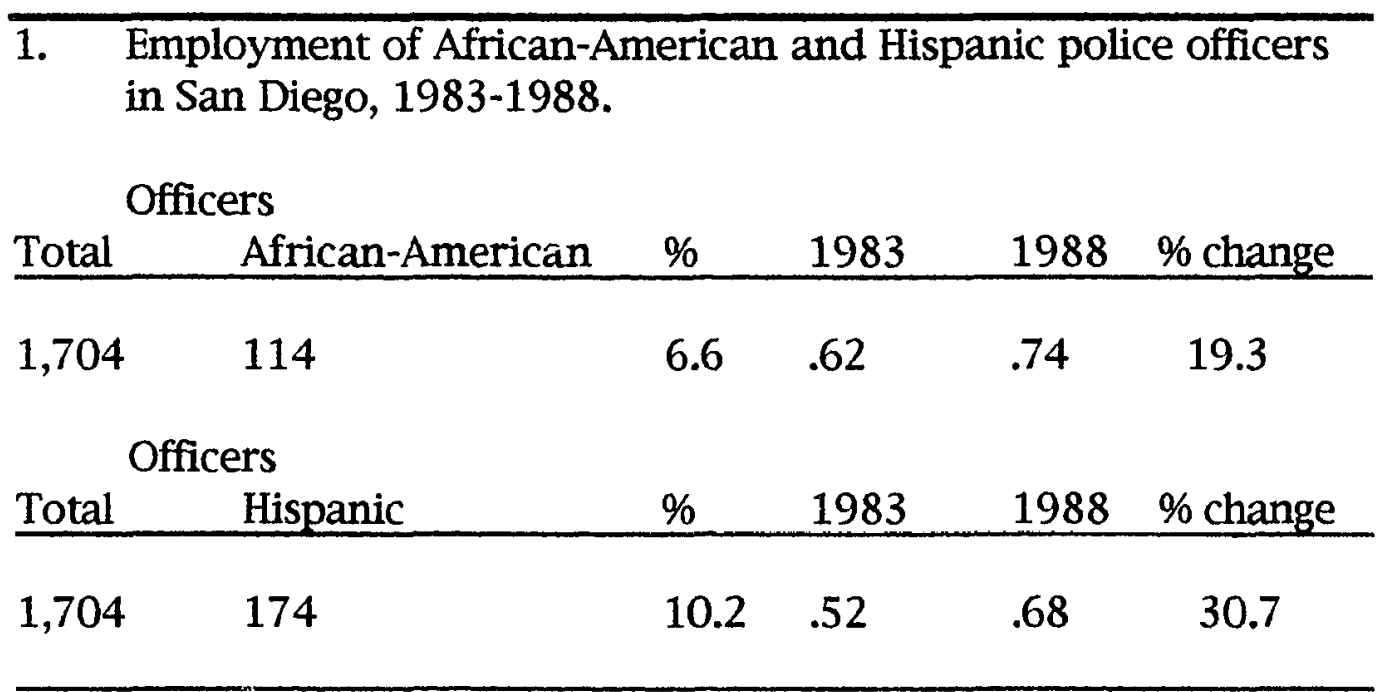


In 1992, Captain George Saldamando was promoted to Assistant Chief, he was only the second Hispanic to reach the rank of Assistant Chief, with the first being Manny Guaderrama who retired in June 1992 to work with Governor Pete Wilson.51 In 1994, the only Hispanic top ranking officers in the San Diego Police Department, in addition to Assistant Chief Saldamando, were; Police Captain David Bejarano; and Police Lieutenants Hank Olias, George Guevarra, and this researcher, Adolfo Gonzales.

By the end of 1994, the San Diego Police Department Personnel Division showed the following Hispanic sworn officers: one Assistant Chief of Police, one Police Captain, 31 sergeants or lieutenants, and 216 officers, agents, or detectives. 52

Female Officers

The beginnings of the movement to employ women in policing occurred during the first half of the nineteenth century. The first "modern" city police organizations were formed in the 1840 s, but it was not until 1910 that the first policewomen were hired by police departments. Alice Stebbins Wells was the first woman hired by the Los Angeles Police Department on September 13, 1910.53 
In 1912, the New York Police Department appointed Isabella Goodwin as its first policewomen detective, who was the first in the United States and maybe the world. 54

For more than half a century, women were exposed to separate criteria for selection, given menial tasks, and denied the opportunity to compete in promotional advancement.55

In 1910, the Los Angeles Police Department assigned Alice Stebbins Wells to duties of supervision and enforcement of laws concerning women and juveniles at dance halls, skating rinks, movie theaters and other places where women and juveniles were bound to socialize.56

On December 4, 1911, the San Diego City Council passed an ordinance creating the office of the jail matron.57 The matrons did not have full peace officer powers. They could only care for female prisoners, as custodial officers. 58

On January 19, 1912, the Department hired Rose Longacre, widow of police officer Edward Longacre, who had served on the force from April 1905 until his death in January of 1909. Rose served for only a few months before resigning on August 31, 1912.59 On December 19, 1912, Chief Jefferson Wilson, an old friend of 
the Griffin's, appointed Ida Griffin as a police matron. Ida Griffin was the widow of County Supervisor John Griffin. Ida Griffin served until 1919 when she married Police Captain Arthur Hill, and resigned shortly thereafter. 60

In 1915, the City of San Diego invited August Vollmer, Chief of Police from Berkeley, California, to study the Department and make suggestions for its reorganization. Chief August Vollmer completed his survey of the Department, and on June 11, 1917, submitted his report to the City Council. Chief August Vollmer made a series of recommendations to the City of San Diego. One of those recommendations was the suggestion that the San Diego Police Department hire policewomen "who shall be mounted in an automobile and assist in investigation of all cases in which females may be involved."61

On July 17, 1917, the City Council acted on Chief August Vollmer's suggestion to hire policewomen. The City passed an ordinance that created the classification of policewomen and set the salary at $\$ 75$ per month. The City did not appoint a policewomen until June 3, 1918.62

On June 3, 1918, the Department first hired two policewomen, Lucille Jeardeaux, 48 years of age and Mary Galvin, 44 years of age. 
XXIV. Eleven female candidates for policewomen. This photo was taken on December 18, 1925. Pictured from left to right (Top row): Mabel R. McPherson, Cara Stevens, Rose Beanon, Sadie Lambert, Dorothy E. Cabana, and Helen L. Hicks. (Bottom row): Rena J. Wright, Jessie Long, Martha M. Seell, Charlotte Dobbins, and Olga A. Nelson. San Diego Historical Society, Photograph Collection. 


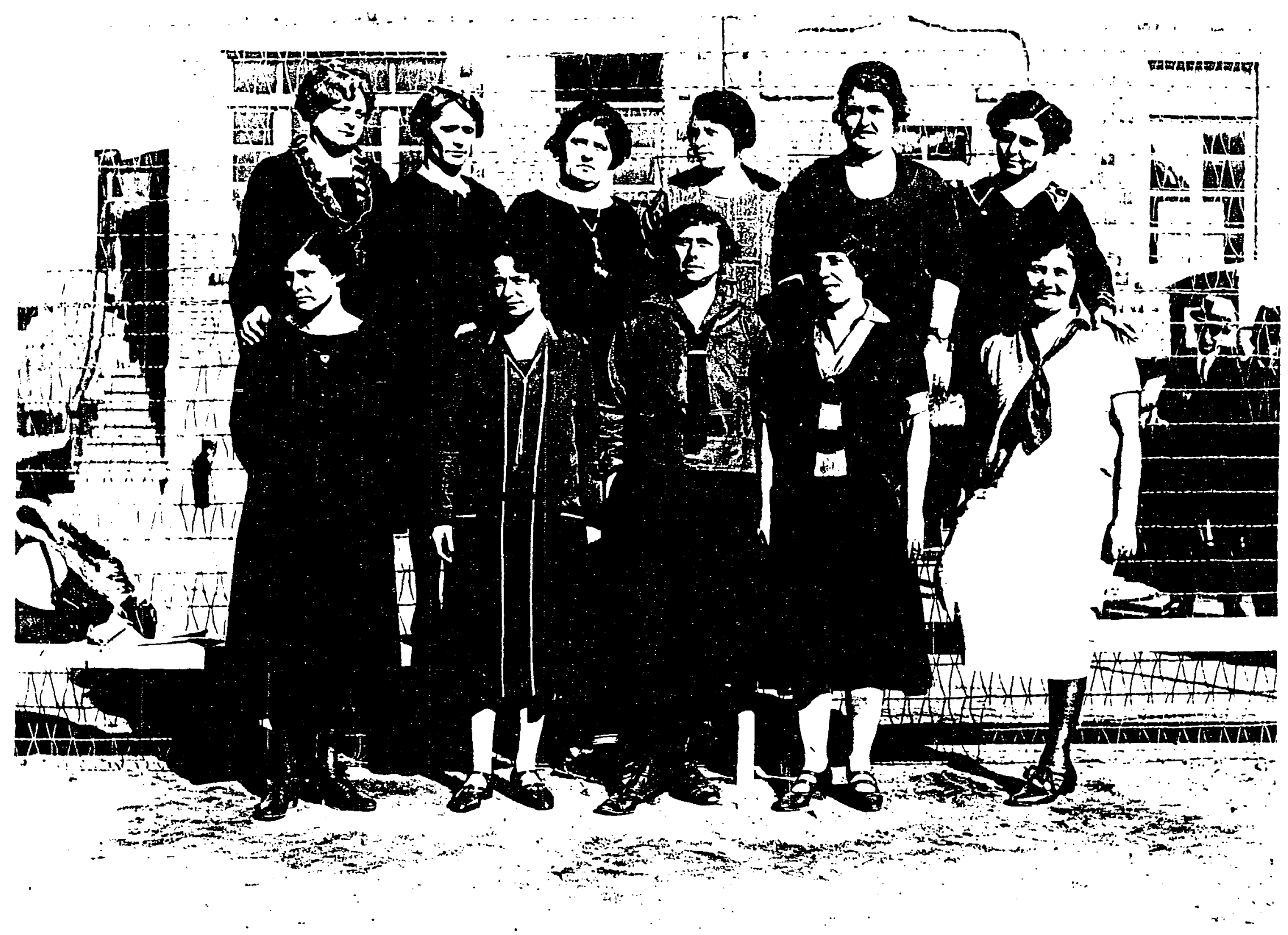


Mary Galvin served only three weeks before resigning on June 30, 1918. Lucille Jeardeaux was terminated; the date not known. 63 Because the Department was unable to retain these women, they had to hire two additional women in order to meet its obligation. The third policewoman hired was Grace Howell. Grace was appointed on July 3, 1918 and served until she was fired on April 30, 1919. The San Diego Police Department's fourth appointee, was Mae Bell Veall, who served as policewoman and later as a matron. Officer Mae Veall was 35 years of age, with five children when she was hired. Mae Veal worked as matron until she retired in December of 1938. Officer Veall was the last policewoman appointee until 1926. On April 20, 1926, Rena J. Wright joined the San Diego Police Department and on April 22, 1926, Olga A. Nelson also joined the police department. These were the first females appointed as policewomen for the San Diego Police Department since 1918. Another woman appointed as an officer was Violet N. Michels. Officer Violet Michels was appointed on September 29, 1936 but was laid off on June 30, 1939. She was later reinstated as a "Matron"caring for female inmates. In September 1939, the Chief of Police, under pressure from the City and many women's organizations, 
ordered the number of female officers reduced from three to one. Violet Michels and Bulah Childress were fired. Two other females, who had been working as police officers, were demoted to "Matrons," less paying jobs. 64

In the 1950 s and 1960s a number of police departments began to hire women to perform in-house, clerical and communications support roles. These women were not sworn uniformed police officers. Their status were much like the parking controllers or meter maids. Some policewomen were used as decoy and performed undercover assignments. But there were still very few opportunities for policewomen to switch to non-traditional assignments, and promotional opportunities were slim. Policewomen were still largely used in crime prevention or juvenile units and assigned to handile female or juvenile cases. 65

With the passage of the Civil Rights Act of 1964, females were given some relief in careers in law enforcement. The courts have supported the addition of women to the law enforcement profession by eliminating entrance requirements which barred almost all women candidates but could not be proven to predict job performance, such as height and upper body strength.66 
In addition to the Civil Rights Act of 1964, several U.S. Supreme Court decisions have also paved the road for women to enter law enforcement: 1) in November 1971, in Reed Vs Reed, the Court ruled that the 14th Amendment prohibited discrimination on the basis of sex; and 2) in 1971, in Griggs Vs Duke Power Company, the Court ruled that any test for hiring "must measure the person for the job, and not the person in the abstract (and that) any educational requirement or test score must be shown to be significantly related to successful job performance." 67

Catherine Milton (1972) found that 1) policewomen remained in clerical or specialized bureaus for juveniles, they were often required to have special education or college degrees because of their special status; 2) most police departments had quotas on the number of women they would hire, usually less than 1 percent of the total sworn force; 3) most police departments had special entrance requirements for those women who were allowed to apply, higher education, different entrance exams, and height requirements; and 4) most departments had differential promotional requirements for women. Women could not take part in the promotional examinations or were limited solely to openings in Women's Bureau. 68 
Lesli Lord (1983) observed that occupational dualism displayed by women in law enforcement is complicated by their presence in only token numbers within most police departments. This created a tremendous pressure to perform, and led to divisiveness and disagreement within the female officer ranks. Lord found that it was not uncommon for a female officer, particularly the policewomen mode, to have greater expectations for the behavior of another woman officer, than would her male counterpart. This phenomena was unfortunate, because instead of the presence of women changing police work, police work was changing women. For some women officers, these new patterns of interactions were challenging and "fun", for other female officers, it's inconceivable and alien.69 The use of women officers on the patrol duties created a significant challenge to traditional police recruitment, selection, and training procedures. Lord said police departments must find qualified personnel who can not only take tests and pass, but who are also of a strong moral character and who want to be police officers. As Lieutenant John Morrison of the San Diego Police Department said in his memoriam to two San Diego Police Department officers killed in the line of duty, "You can't be a cop 
because you didn't get some other job. You can only be a cop because you want it."70

The Crime Control Act of 1973 banned sex discrimination by police departments that receive federal aid. The agencies with 50 or more employees who received $\$ 25,000$ or more in federal grants were required to implement women's equal opportunity programs and/or policies. 71

Chief Ray Hoobler, after a brush with state and federal affirmative action groups, decided to put female officers back in uniform and assigned them to street duties. Of the fourteen policewomen on the department at the time, five, who were employed since 1954, were allowed to remain in investigations. The rest of the women were reclassified as police officers, and put back into uniform. Not all of the policewomen who were assigned to street duties were immediately assigned to beats. Only two policewomen were assigned to those duties. One of the two females was Alicia Lampert; she is now a police sergeant in charge of a homicide team.

Those female officers who refused to work the streets, resigned. Five female officers were reassigned to the border check point, at the San Ysidro Port of Entry, for a test period in 1971. 
During 1974 , officers at the border check point interviewed 18,995 juveniles. Officers denied entrance to 6,430 of those juveniles. 72 Despite the impressive number of juveniles who had been diverted by officers from visiting Tijuana, unescorted by parents or legal custodians, the recovery of stolen goods, and the many arrests made during the seventeen years of operation, the City Council closed the inspection station when state funding was withdrawn. 73

In 1977 , there were 1,033 officers working for the San Diego Police Department. Of those 1,033 officers, 98 were considered members of minority groups, who were employed as sworn police officers. Fifty-five of the 98 were Méxican-Americans, 34 were African-Americans, 29 were women, five were Indians, two were Filipinos, and two were Asians. Only 10 minority officers occupied supervisory positions; one Méxican-America police lieutenant, six Méxican-American police sergeants, two Native Americans police sergeants, and one African-American a police sergeant. There were no women in supervisory positions, even though a female officer, Marilyn (Lynn) Donnelly, had 19 years of service by 1974. Another female officer, Bernice Caswell, managed to get her name on the sergeant's list in 1973, but was passed over for promotion.74 
When Chief Bill Kolender took office in 1975, there were sixtyfive female officers in the Department, all of whom were either detectives or newly hired officers who had been in the field a very short time. There were no sergeants or lieutenants, let alone captains. When Chief Bill Kolender retired in July, 1988, there were 196 female officers in the San Diego Police Department, of whom ten were sergeants and three were lieutenants. 75

The possibility of female officers working their way up to the top ranks of assistant chief, captain or lieutenant seemed a distant dream back in the 1970s, and the possibility of seeing a female officer riding a 700 pound police motorcycle on the streets of San Diego or flying a police helicopter was a dream at best. But, female officers have come a long way. 76

In 1981, San Diego Police Department experienced another first, the promotion of a female officer to the rank of police lieutenant. Sergeant Connie Van Putten, 37 years of age at the time of appointment, became the first woman lieutenant in the history of the San Diego Police Department. In 1977, Connie Van Putten had been promoted to Police Sergeant and in 1985, she passed the Captain's examination. 77 
XXV. Connie Van Patten in front of the Northern Substation in La Jolla, at Herschel and Wall Streets, circa 1968. The men in the photo are (top row, left to right): Ty Reid, Gary Schneider, Bob Kirkendall, and Hal Sutton. (Bottom row): Bud Randall and Mike Genna. San Diego Historical Society, Ed W. Kenney Historic Collection. . . 
In 1994, the San Diego Police Department had the following female officers assigned to various top-ranking or specialized positions: Assistant Chief Rulette Armstead, has the honor of being the highest ranking African-American in the Department's 105-year history; Assistant Chief Nancy Goodrich; Captains Barbara Harrison, Cheryl Meyers, Lesli Kay Lord; Lieutenants Shawna Selby, Victoria Binkard, and Joyce Edger; Officer Lori Luhnow, the first female motorcycle officer for the San Diego Police Department; and Officer Theresa Clark, the first female helicopter pilot in the history of the San Diego Police Department.78

Former Chief Bob Burgreen, in a 1992 interview with the San Diego Union-Tribune said, "Up until 1974, women could only work investigations or patrol and could not even take a sergeant's exam. It was only after that we saw women move through the ranks, and now 20 percent of all our entry level are women." The Department had endured a certain amount of criticism over the years in regards to the small number of minorities in upper-management. Chief Bob Burgreen had indicated he was favoring the appointment of minority candidates, which he delivered in 1992.79

Initially, the San Diego Police Department hired only four 
women as the City budgeted only four positions. During the next fifty years additional positions opened slowly, and by the end of 1994, the Department had a total of 256 policewomen; two were high ranking Assistant Chiefs of Police, three Police Captains, 29 sergeants or lieutenants, and 222 officers, agents or detectives. 80

The 1990 United States Census recorded the population for the City of San Diego at 1.1 million. The San Diego Police Department Personnel Division showed the ethnic comparison between 1991 and 1994 of sworn personnel as follows:

2. Total percentage of sworn officers (all ranks) for 1991 and 1994, compared with the City's 1990 Census local population.

$\begin{array}{llll} & \underline{1991} & \underline{1994} & \text { City's Population \% 1990 } \\ \text { White: } & 76.5 \% & 74 \% & 58.7 \% \\ \text { Black: } & 7.4 \% & 8 \% & 8.9 \% \\ \text { Latino: } & 11.6 \% & 13.2 \% & 20.7 \% \\ \text { Asian-Pacific: } & 3.6 \% & 4 \% & 11.1 \% \\ \text { Other: } & 0.8 \% & 0.8 \% & 0.6 \%\end{array}$

Source: San Diego Police Personnel and 1990 U. S. Census Report. Border Alien Robbery Task Force (BARF): 1976 - 1978

The Border Alien Robbery Task Force (BARF) was established in the late 1970s, in order to patrol the undeveloped canyons just north of the San Ysidro/Tijuana border. These canyons and rural 
areas were used as the primary routes for illegal alien and narcotics smuggling into the United States. Border bandits from both sides of the fence preyed on the aliens as they struggled northward to the land of prosperity and jobs. Murder, rape, robbery, and assault on these mostly docile aliens, forced the San Diego Police Department to make a bold move into the international law enforcement scene. 81

Members of BARF were mostly Spanish speaking officers. These officers worked in plain clothes and would disguised themselves as Méxican migrants crossing illegally into the United States. The goals of the BARF team were to blend into the alien population, as they moved north from the border into the canyons, and apprehend border bandits. The BARF officers patrolled the hills and canyons along the border on a nightly basis. Once the border bandits moved in to assault or rob the disguised officers, the officers would make the arrest. This initial confrontation often resulted in gunfire between the bandits and officers. After many high-profile and deadly shootings, the San Diego Police Department administration felt the border region was too deadly for both officers and bandits alike. In 1978, the BARF task force was suspended because of the extreme border violence. 82 
XXVI. Members of the original Border Alien Robbery Task Force (BARF). From left to right: Ernie Salgado, Carlos Chacon, Rob Hurt, US Border Patrol Ageni, Sergeant Manny Lopez, US Border Patrol Agent, Tony Puente, US Border Patrol Agent, US Border Patrol Agent, and in the center is Lieutenant B. Synder. Photo courtesy of Ernie Salgado. 


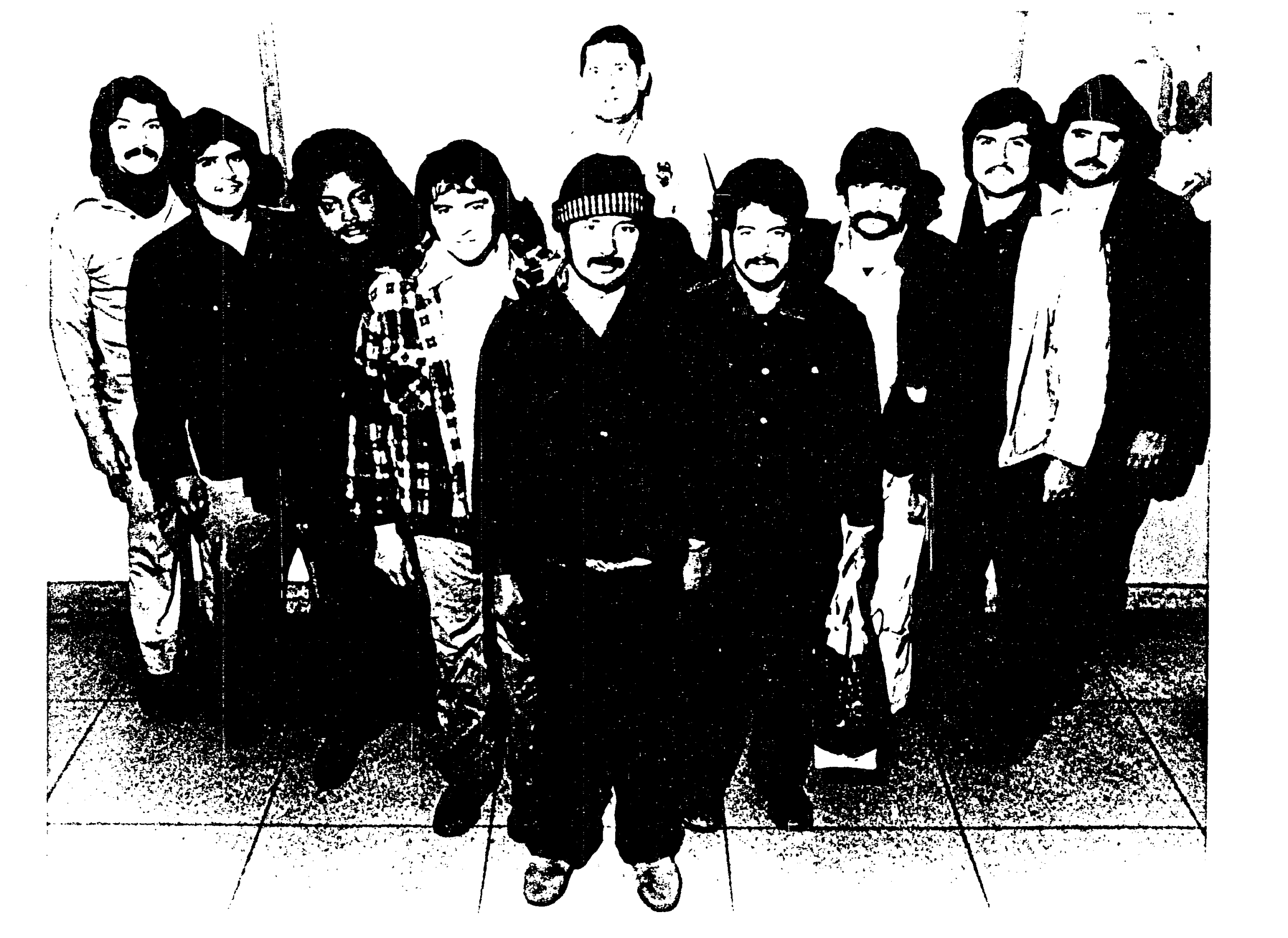


One of the BARF's most controversial shootings incidents occurred along the fence near Colonia Libertad, in México and Otay Mesa, on the United States side of the border. Two Tijuana Municipal police officers, Pedro Espindola and Jesus Hernandez, confronted a group of aliens along the fence line. When the aliens refused to come to the officers, the Municipal police officers came to the group. The group was not responding like most aliens would respond to the Méxican police officers. According to the Méxican officers, this group was behaving more like border bandits. Both Municipal police officers walked about six feet into the United States territory, with guns drawn, and ordered the aliens to return to México with them. When the aliens refused, one of the Municipal police officers pointed a gun towards the aliens. As it turned out, this group was not a group of undocumented aliens, but instead, they consisted of officers from the BARF team. The BARF officers immediately identified themselves as police officers, then a shoot-out occurred. When it was all over, both Tijuana Municipal police officers were wounded as was San Diego Police Officer Carlos Chacon, a BARF member.83 The Border Crime Prevention Unit (BCPU): $1984-1988$ A gap in law enforcement at the border region became 
apparent as the bodies and victims of border violence began to escalate after the removal of the BARF team. 84 In January 1984, a similar task force as BARF was established by the San Diego Police Department and the United States Border Patrol. This team was called the Border Crime Prevention Unit (BCPU) and operated under a different philosophy than the BARF team. Members of BCPU actively worked with U. S. Border Patrol Agents as team members. 85

Unlike the BARF team, members of the BCPU team were not working in an undercover/plain clothes capacity, but were dressed in full uniform and their tactics consisted of low-key operations. 86

One of the original members of the Border Crime Prevention Unit, San Diego Police Officer Felix Aguirre, stated in an interview with the US Magazine, that the team members were dressed in police uniforms with their police batons dangling from their duty belts. Every time the officers would try to sit, the batons would bang around and make noise. When they tried to chase after possible suspects, the batons would flying all over the place. After that experience, the officers would not take the police batons out into the field with them. 87

Members of BCPU participated in approximately 120 hours of 
XXVII. Border Crime Prevention Unit (BCPU) - left to right (top row): Jeffery Wolder, Linda Miller, Jim Stewart, Michael Mendez, Robert Coleman; (bottom row) Larry Gordon, Tony Ruiz, Sgt. Hisks, R. C. Smith, Richard Ensign, Gary Will , and Kelly Mathews. Officers in the light colored uniforms are from the San Diego Police Department and the Border Patrol agents are dressed in the dark uniforms. San Diego Historical Society, Photograph Collection. 


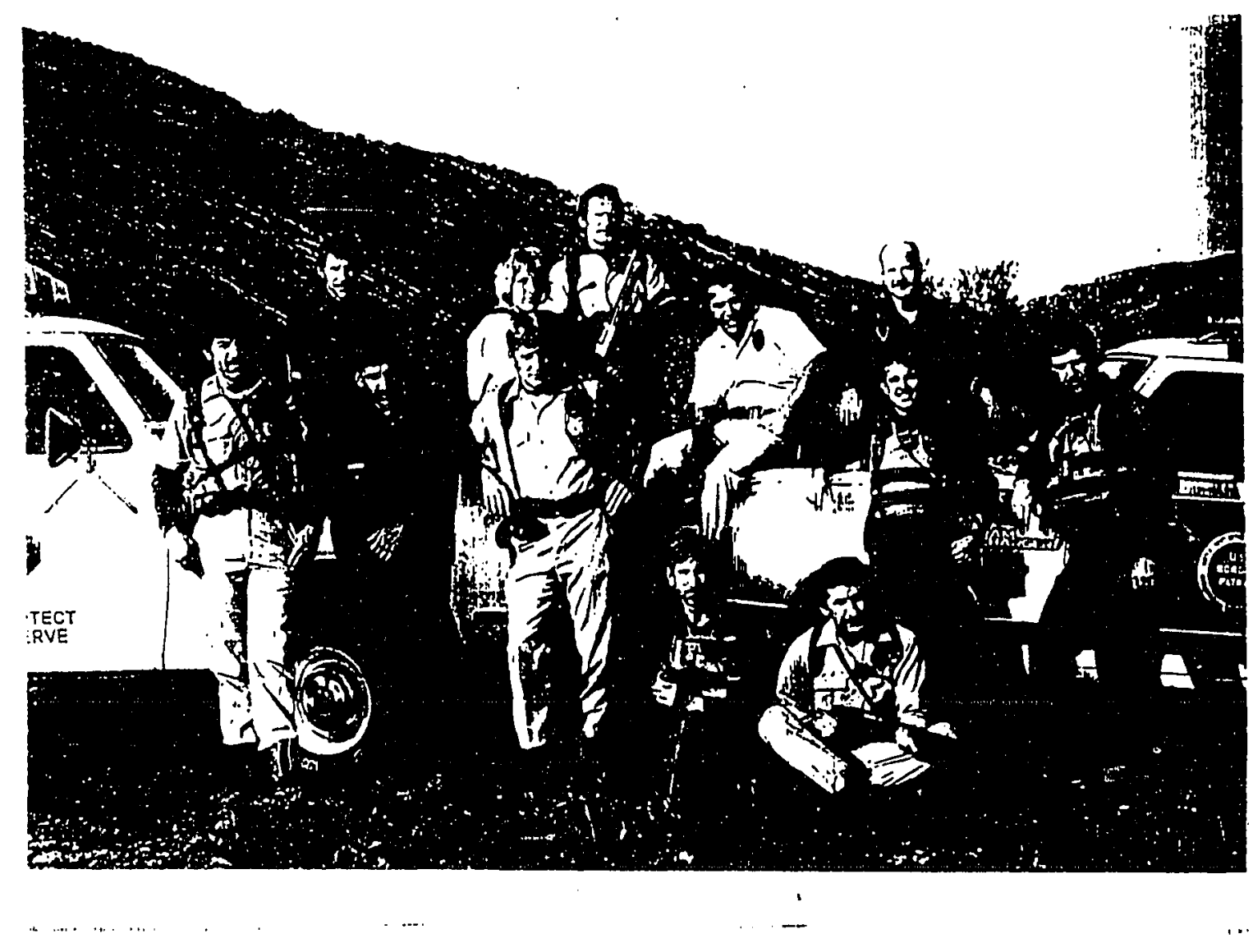


classroom instruction and field training prior to being assigned to duties in the hills and canyons. In addition, an operations manual was introduced. This manual covered various topics, including the responsibilities of each team member and tactics for field deployment. On February 28, 1985, the Chief Patrol Agent for the United States Border Patrol San Diego Sector, Alan E. Eliason, approved the operations manual for both U. S. Border Patrol and San Diego Police Department. U. S. Border Patrol Chief Eliason said:

It is obvious that much thought and consideration by both members of the Border Patrol and the San Diego Police Department were involved. The combined effort has produced a set of guidelines by which all members of the Border Crime Prevention Unit can continue to operate as the elite, professional team that they have been. 88

The combined task force disrupted the bandits' lucrative business and compiled impressive statistics. In contrast to BARF, the officers of the BCPU team took a high visibility profile by walking and patrolling the region in uniform and prominently displaying their badges. 89 The San Diego Police Department administration hoped that this higher profile would reduce the number of armed confrontations between bandits and police officers. 90

During this period, the violence along the border was out of 
control. In early May, 1985, while BCPU members were patrolling the canyons along the international border, they saw three subjects walking from the east to the west, typical border bandit behavior, along the north rim of a canyon. Undocumented migrants would usually walk north, quickly and safely, without stopping to talk to other groups. The group of three people, would sometimes contact other groups of undocumented migrants. As the team members walked through an area known as the Pistol Range, they saw the group of three people hiding behind some bushes. The suspects were armed. As the officers waited, the group of three suspects sent one of their companions to check-out the officers. When this person got to within fifteen feet from the officers, he recognized them as police officers and began to run back to his group. The officers identified themselves in Spanish as police officers and ordered the subject to stop and not move. The subject discarded a .22 caliber handgun and fell to the ground with his hands under his body. As the officers attempted to pull the subject's arms from under his body, the subject resisted and fought back. At this point, a second subject confronted the U. S. Border Patrol Supervisor Agent, Fred Stevens. While Supervisor Fred Stevens' attention was focused on the second 
subject, a third subject approached from behind in an ambush style. This subject shot Supervisor Fred Stevens at point blank range. Even though, Fred Stevens was knocked down to the ground, the suspect continued shooting. Supervisor Fred Stevens was shot in the left wrist, right leg, left side, and two rounds hit Stevens in the chest, but his safety vest stopped these bullets. When it was all over, one of the subjects was killed, another was taken into custody, and a third bandit fled back into México.91

On April 21, 1986, members of BCPU were resting along an area known as "E-1" which is about a quarter mile east from the San Ysidro Port of Entry. The team members were seated near a large hole in the fence, that divides United States and México. The officers were suddenly approached by two suspects. One of the suspects said in Spanish, Judicial (Méxican police officer) and pulled back his coat, pointing a pistol towards the head one of the officer's.92 The BCPU team members quickly responded and opened fire at the suspect, fatally wounding him. The subsequent investigation revealed that the suspect was not a Méxican law enforcement official but a border bandit. Furthermore, the suspect's weapon was not a real firearm, it was a pellet gun. 
On April 27, 1986, members of the BCPU team witnessed an armed robbery, along a foot path on Airport Road near the international border. When the suspects saw the BCPU officers, they faced-off with the officers. Both suspects approached the officers in an ambush style and produced handguns. Just then the BCPU officers began firing. When it was all over, one suspect was fatally shot and the second suspect was wounded.

In another case, on May 19, 1986, as the BCPU team members were walking through the canyon area known as the " 211 bushes," two Hispanic males came toward the group of officers, in an ambush style. Both subjects were carrying what appeared to be short barrel shotguns, wrapped in towels, in a combat fashion. As the first subject came towards the officers, he yelled for the officers to get on the ground. The second suspect moved into position behind the group of officers. As the first subject approached the officers, one of the officers opened fire and fatally wounded the subject. Upon closer investigation, the officers found that the weapons were sticks wrapped in towels. During the initial shooting, one of the officers yelled to the other team members to cease fire. As a result of this team work, the second subject was not injured but simply taken into 
custody. 93

The violent nature of the border bandits and the physical environment of the border, created a deadly situation for the members of the border task force. The border canyons are often so dark that it is difficult to distinguish one person from another even if that person is fully dressed in a police uniform. The results were, border bandits confronting fully armed uniformed officers. Because of this, shootings continued at a high level along the border region.94

The San Diego Police Department administrators struggled to find answers to the dilemma of providing effective but safe operational approach to crime prevention along the international border. The BCPU team was pulled out of the hills several times in the wake of "controversial" shootings. 95

On December 20,1988, Chief Bob Burgreen sent a memorandum to Deputy Chief Rice and Assistant Chief Stamper, outlining some concerns that two Southern Division officers from the Border Crime Prevention Unit (BCPU) had regarding the safety and operation of the unit. The officers were concerned that there were no physical requirements for being a member of the team, no special testing for night shooting, no testing was conducted for night vision, and the 
restriction of two 4 month tours of duty. These issues were addressed and the members of the BCPU were allowed to extend their tour of duty. 96

Since the inception of the Border Crime Prevention Unit and their deployment in late 1984 , members of the BCPU were involved in a total of thirty-five shooting incidents. These shooting incidents resulted in the following casualties: twenty-six suspects were shot or wounded; eighteen suspects were shot and killed; and three members of BCPU were shot and wounded. In forty percent of these shooting incidents, one or more suspects fled into México following the shooting. 97

Prior to working the canyons, members of the Border Crime Prevention Unit participated in two weeks of training which included an in-depth weapons instruction, tactics for response to ambush attacks, learning to work in an area without much lighting, and being able to work in small unit tactics with personnel from the United States Border Patrol. This team worked as two elements--Alpha and Bravo teams. The alpha team was the contact element and the bravo team was the cover element.98 These teams worked to protect and serve along the international border at the San Diego and Tijuana 
border region. The poor, the meek, and the beaten continued flooding northward in long-suffering silence. The mere existence of illegal immigrants created three different industries: the cheap Méxican labor; the transportation field providing guides, vehicles, and safe houses on the route both south and north; and the predatory element, the dozens, perhaps thousands of committed criminals devoted to preying on the innocent.99

In 1989, the "Hill Team," the Border Crime Prevention Unit, was again pulled from the canyon because members of the team were involved in a number of controversial shootings. The managing editor of The Informant, Lieutenant John Morrison, responded to the removal of the Border Crime Prevention Unit with four points of logic. Lieutenant Morrison stated the following:

1) the canyons along the international border are prowled by vicious bandits. Often going beyond simple robbery and overcoming the infrequent victim resistance; 2) even though the victims are usually victims of law violators themselves, committing the crime of entering the United States, the officers have a moral duty to protect them as fellow human beings from the predatory criminals. It may seem unusual for some people to understand that SDPD fields a unit whose duty is to protect people that are here in an illegal status, but that duty is morally and ethically much greater than any immigration law; 3 ) the suspects in question are armed, murderous, preying upon mostly defenseless and needy element. They owe society nothing, respect no law, and if challenged, will not be taken 
easily; and 4) given the determination on both sides, somebody's going to get hurt. Some will die. For civilization's sake, it should more appropriately be the predators than the protectors. 100

James Nickel (1983) agreed with John Morrison when he said, that the most important point about undocumented aliens is that they too have human rights, rights which result from one's humanity, not from one's citizenship status. James Nickel went on to argue that everyone is obligated to refrain from victimizing undocumented aliens, and at least one government should be obligated to protect and uphold these rights.

James Nickel acknowledged that some people might object to his contention that governments are obligated to uphold the rights of undocumented aliens present in their territories by claiming that aliens forfeit their human rights when they crossed illegally into a country. Furthermore, some countries require those convicted of serious crimes to forfeit some of their civil rights, no country strips criminals of all legal protections. And since illegal entry is a minor crime, there is little basis for the view that undocumented persons illegally in the country forfeit all human rights. Police brutality would not be tolerated even if it were directed toward undocument- 
ed persons. Police officers and U. S. Border Patrol agents have an obligation to protect and serve. The human rights obligation does not preclude the U. S. Border Patrol from deporting undocumented persons in accordance with due process of law.101 Border Crime Intervention Unit (BCIU): 1989 - 1994

In May 1989, the Border Crime Prevention Unit resumed operations after four months of inactivity. However, the team's name was changed to the Border Crime Intervention Unit (BCIU). The Unit was responsible for patrolling fourteen miles of border, with most of the operations focused in a five square mile area west of the San Ysidro Port of Entry. Migration trends and U. S. Border Patrol tactics forced most illegal crossings into the levee area of the border. Between January 1989, and November 1989, victims of border violence along the international border reported to the San Diego Police Department the following crimes: 43 robberies, three assaults, two rapes, and two homicides. Most of the crimes occurred along the border fence, in areas known as W-9, W-3, Steward's Bridge, and South Levee.102 The homicides were committed within a mile from each other, on the South Levee. The most frustrating obstacle facing BCIU was the close proximity of the international 
XXVIII. Members of the Border Crime Intervention Unit (BCIU), U.S. Border Patrol Supervising Agent, and members of the SWAT Special Response Team (SRT), collaborating to form the BCIU enforcement team. Photo courtesy of San Diego Police Agent Allen Hayward. 


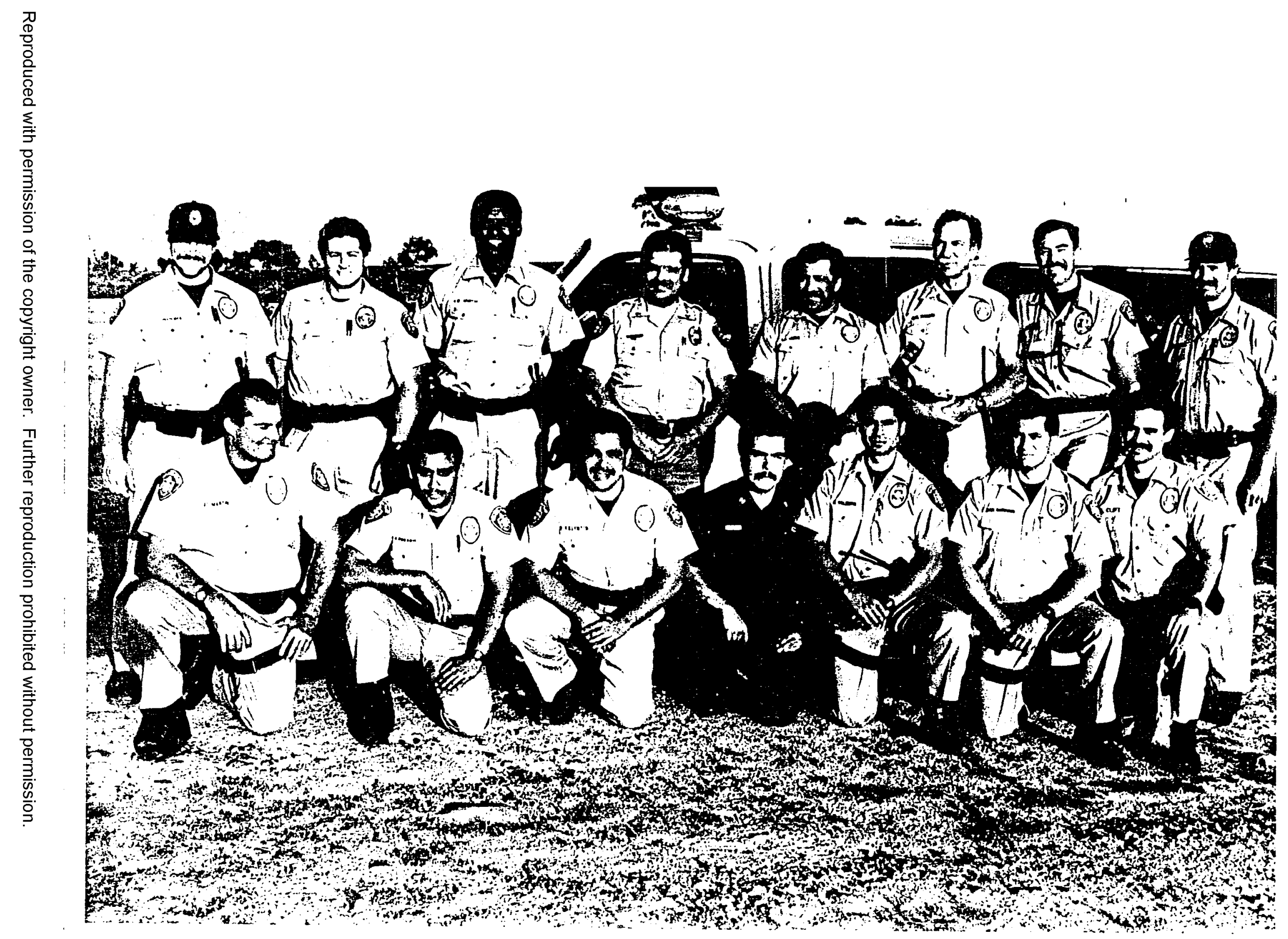


border, which allowed the suspects an easy escape route into México. From the fence line, the suspects were able to operate safely by running to the north or south depending on which law enforcement agency was working the region. 103

The Border Crime Prevention Unit compiled the following statistics for the respective years. These figures indicate the number of acutal violent crimes reported to the Police Department by victims of border violence.

3. Total number of selected violent crimes along the San Ysidro/Tijuana border region, 1984-1988.

\begin{tabular}{lcccc} 
Year & Murder & Rape & Robbery & Totals \\
1984 & 11 & 19 & 272 & 302 \\
1985 & 12 & 25 & 312 & 349 \\
1986 & 5 & 13 & 157 & 175 \\
1987 & 4 & 9 & 84 & 97 \\
1988 & 11 & 8 & 43 & 62 \\
\hline Total & 43 & 74 & 868 & 985 \\
\hline
\end{tabular}
Source: San Diego Police Border Crime Prevention Unit.104

On January 1, 1990, five uniformed officers and a patrol sergeant were assigned to the Border Crime Intervention Unit. The 
primary task of this team was to work as a high visibility unit along San Ysidro Boulevard, combating the ongoing problems in the area. These officers worked on bicycles, foot patrol, but were not allowed into the hills until March 1990 . The team was only allowed to work the hills twice a week, the remainder of the time had to be spent working along the San Ysidro Boulevard. Members of BCIU were only allowed to respond to the hills if there were reports of crimesin-progress or when the U.S. Border Patrol would request their assistance. In addition, it was the policy of the command, that before team members could respond to the hills, they had to obtain approval from the BCIU's lieutenant. This policy remained in effect until June 29, 1990.105

On June 22, 1990, the California Legislature Joint Committee on Refugee Resettlement, International Migration and Cooperative Development, held a joint interim hearing on International Migration and Border Violence, in San Ysidro. The Hearing was chaired by Senator Art Torres. The purposes of this Hearing were: to assess the border region situation; to focus on the increased tension and violence; to increase general awareness; and to identify an appropriate response. The agenda included governmental entities 
from México and San Diego, academians, citizen groups, U. S. Border Patrol and law enforcement agencies. Some of the specific issues that were addressed at this Hearing were: 1) human rights violations. The group wanted to establish a basic understanding of migrant's rights, extent and nature of rights violations, migrant's access to redress Civil Rights violations; 2) impact of current Border Patrol and law enforcement policies, including the effect of increased drug enforcement on migrant population, and controlling the use of excessive force; and 3) several other related issues. 106

Dr. Gustavo del Castillo, Director of United States Studies at El Colegio de la Frontera Norte, addressed the Committee Hearing on International Migration and Border Violence, and stated that over the last decade, México had undergone a rapid social and economic transformation. In addition, the Tijuana/San Diego region was the most intense international crossing point between two nations anywhere on earth. Thus, Dr. Castillo understands that conflict and friction will arise in an area where such intense social interactions are taking place, yet the death of Méxican workers, women and children, can not be explained away.

Dr. Castillo argued that Méxican border bandits, combined with 
the actions of San Diego Police and the United States Border Patrol, were responsible for the death of Méxican nationals. He said that this situation must be solved in an atmosphere of bilateral cooperation, with an understanding and tolerance of cultural differences and with a political will unencumbered by ideologies of racial superiority and manifest destiny. 107

Dr. Castillo asserted that the Méxican worker is more diversified today than ever before and is seeking other employment opportunities rather than just agricultural work. These workers, Castillo said, have had significant socioeconomic characteristics which will influence the jobs they will undertake and their expectations.

Dr. Castillo reported that $97 \%$ of all workers crossing the border had 12 years of education, and $95 \%$ of the workers travelling north had a job in México before crossing into the United States. 108

Roberto Martinez of the US/México Border Program of the American Friends Service Committee, also addressed the Committee Hearing on International Migration and Border Violence. Roberto Martinez reported the violence along the border between Tijuana and San Diego had been escalating by border bandits, vigilante type groups, and gang members. He said that these criminals were no 
longer ordinary bandits, but criminals committing crimes that were often motivated by racism and hatred.

Roberto stated that we could no longer be certain whether any given crime was committed by Méxican nationals or by gang members from the United States .109

Mr. Martinez was not in support of police enforcement along the border. He said, "It has been no less chilling to learn this week that the Chief of Police in San Diego, Bob Burgreen, has announced his intention to send a SWAT Unit known as the Special Response Team, to back up the Border Crime Prevention Unit, already patrolling the border, as well as provide back up for the USBP." Roberto recommended the formation of a Binational Commission for the Southern California and Baja California Norte regions. The function of the Commission would be to search for alternatives that can reduce abuse and tensions while enhancing human dignity and respect for law. Furthermore, it would address issues such as use of deadly force by border law enforcement agencies, and violence against immigrants by individuals and organized groups. 110

In addition to academia and community representatives, law enforcement officials were also invited to speak before the 
Committee's Hearing on International Migration and Border Violence. Representing the San Diego County District Attorney was Richard Neely, second in command. Mr. Neely stated that in San Diego County law enforcement had taken the position that they could not ignore the needs of the people in the region, to be protected, irrespective of the fashion in which they arrived here. Mr. Neely suggested that local law enforcement agencies had teamed up with federal agencies to form partnerships in an effort to protect the migrants and restore some semblance of order in the canyons and hills in the border region.

Mr. Neely said that the District Attorney's Office has attempted to contribute to the public safety by prosecuting violent criminals in cases which have proven difficult to investigate and in which the witnesses were often frightened, uncooperative or, missing by the time of trial. Mr. Neely suggested that the State of California fund an International law enforcement task force comprised of local law enforcement officers from the United States, Méxican police officers and prosecutors from both sides. The concept involved Méxican and American law enforcement officers patrolling the hills and canyons on both sides of the border, working side by side. Thus when 
criminals were apprehended by the international team, they would be prosecuted under California or Méxican law by prosecutors assigned to the international task force.111

Speaking for the San Diego Police Department at the Committee Hearing on International Migration and Border Violence was Assistant Chief Manny Guaderrama. Chief Manny Guaderrama reported that in 1989 the United States Border Patrol pulled-out of the joint task force, leaving the San Diego Police with a small squad of officers to patrol the border. Prior to the United States Border Patrol pulling-out, San Diego Police Department officers worked in concert with the Border Patrol agents preventing border violence, but to little avail, the crimes were continuing.

Chief Manny Guaderrama said that the sole purpose for the border team was to protect people who were in the area between the San Ysidro Port of Entry and the Pacific Ocean. Chief Manny Guaderrama reported that the San Diego Police was going to increase the number of officers assigned to the border region. He said the officers' main function would be to gather intelligence information, do some work with the Méxican police, and focus on the border bandits. 112 
In June 1990, members of the San Diego Police Department's Special Weapons and Tactics (SWAT)--Special Response Team (SRT) joined members of BCIU. This addition of personnel provided for seven days a week coverage along the border and additional training. officers from the SRT were directed to provide a high profile, carry whatever weapons were necessary, and make many contacts in the hills as they could.113

At the end of July 1990, a team of Méxican Law Enforcement Officers (M.L.E.O.) became involved in patrolling the border. This team was later called the Beta Group. In the beginning, the U.S. Border Patrol agents donated, to the Méxican law enforcement officers, portable radios, bullets proof vests, flashlights, and binoculars. Unfortunately, the M.L.E.O. were never given proper training. There was very little, if any, communications between BCIU and M.L.E.O. During this period, members of BCIU were communicating between themselves by clicking their fingers or banging rocks together. While members of SRT were talking to each other by the use of state-of-the-art radio communications system. Later, BCIU was able to obtain a similar communication system as SRT. In addition, BCIU obtained better radios which had the capacity 
of receiving and transmitting over the same radio frequency as the Méxican officials, thus allowing the American and Méxican officers to communicate with each other over their portable radios.114

On February 29, 1992, Javier Valenzuela, Commander of the Beta Group, provided the San Diego Police Department with a letter authorizing members of $\mathrm{BCIU}$ to use their radio frequency for joint operations. This letter was sent to the San Diego Police Department's Communications Division and the City of San Diego's Radio Shop for inclusion in their communications systems. The San Diego Police Department was able to obtain a radio license from the Federal Communications Commission (FCC).115 The improved communications allowed for better working relationships between officers from the BCIU and the Beta Group.116

Members of SRT and BCIU began conducting training sessions for the Beta Group. These training sessions consisted of basic firearms tactics, radio communications, and lectures on various subjects. Members of BCIU also contacted their Méxican counterparts twice a week to exchange information on bandit activity in the region. Towards the end of the year, both units began working together as one team, effectively controlling crime.117 
XXIX. Logo of the Border Crime Intervention Unit (BCIU). This logo used to read, “Cazadores de baja pollos." But After several meetings with members of the Beta Group, it was determined that the term baja pollos appeared offensive and was changed to bandidos. When the SRT officers joined the $\mathrm{BCIU}$ team, people in the field would call the officers Los SWAT. Consequently, the logo was modified to include the name of each of the elements comprising the join operations of BCIU--SDPD, BCIU, USBP, BETA, and Los SWAT. The logo has an universal "NO" sign over a bandit holding a gun. 


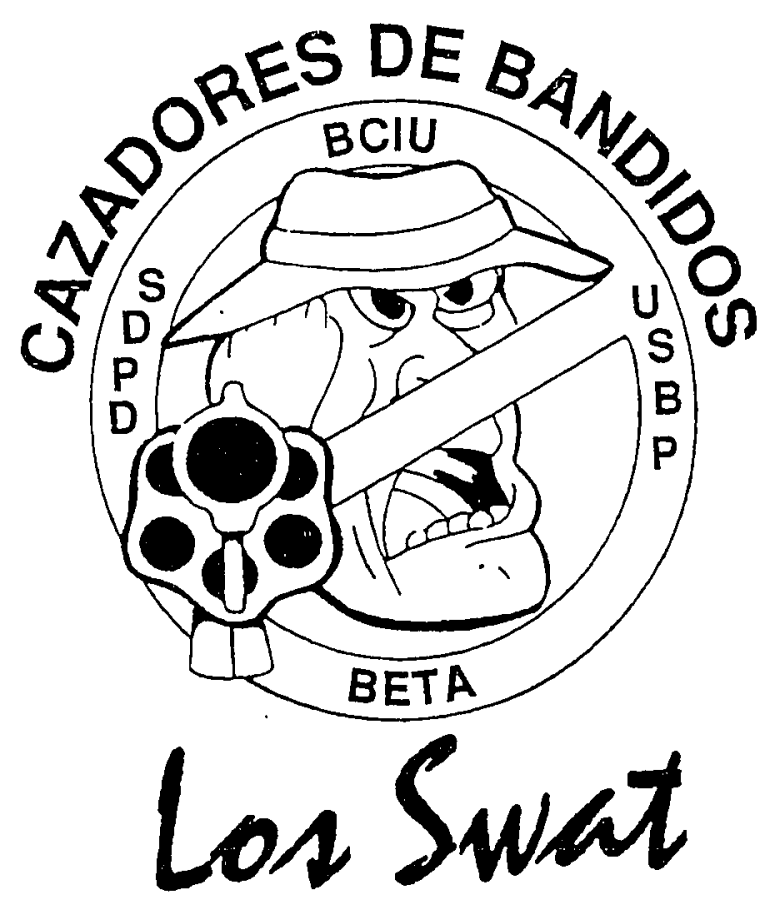


As BCIU's involvement along the border increased, it became imperative to revise the operations manual. On February 29, 1992, this researcher updated the Border Crime Intervention Unit's operations manual to include: goals and objectives, unit structure, administration, intelligence, tactics and operations, and uniform classification and equipment. The BCIU was comprised of selected volunteers from Southern Division and members of the Special Response Team from SWAT. The Southern Division's captain was the commanding officer of the Unit. A patrol lieutenant from Southern Division managed the team and a patrol sergeant form Southern Division was responsible for the field operations of the team. The United States Border Patrol provided a supervising agent, who acted as a liaison between U.S. Border Patrol arid San Diego Police Department's BCIU. This U.S. Border Patrol agent participated as a team member and attended all of the training sessions. 118

As a result of the efforts of the BCIU, the United States Border Patrol, and the Beta Group, the violence along the border was reduced to a manageable level. The below listed data reflects the efforts of these officers: 
4. Total number of selected violent crimes along the San Ysidro/Tijuana border region, 1989-1994.

Border Crime Intervention Unit Statistics (BCIU) 1989-1994:

\begin{tabular}{lcccc}
\hline Year & Murder & $\underline{\text { Rape }}$ & $\underline{\text { Robbery }}$ & $\underline{\text { Totals }}$ \\
1989 & 9 & 2 & 52 & 63 \\
1990 & 8 & 4 & 102 & 114 \\
1991 & 1 & 3 & 114 & 118 \\
1992 & 0 & 4 & 72 & 76 \\
1993 & 0 & 3 & 25 & 28 \\
1994 & 1 & $\underline{6}$ & 14 & 21 \\
Total & 19 & 22 & 379 & 420 \\
\hline
\end{tabular}

Source: San Diego Police Department BCIU.119

Blue Ribbon Committee on Violence: 1991

On December 18, 1991, Chief Burgreen and City Manager, Jack McGrory, established a Blue Ribbon Committee on violence. The mission of this committee was:

To examine the violent crime in San Diego and to develop strategies to reduce violent crime using resources from the entire community. 120

Five subcommittees were established as follows: Border Issues (Chair: Michael Duckor); Domestic Violence/Child Abuse (Chair: Nancy 
Montalvo); Gangs (Chair: Ray Smith); Hate Crimes (Chair: Morris Casuto); and Narcotics (Chair: Andrea Skorepa). Of interests for this dissertation was the Border Issues Subcommittee report. This subcommittee identified four topics for investigation: 1) violence against undocumented persons committed along the border zone; 2) violence against undocumented persons committed away from the border zone; 3) violence committed by undocumented persons, both on and away from the border zone; and 4) law enforcement abuse, corruption or related treatment issues consisting of violence against undocumented persons. 121

The subcommitroe members made a few observations, and offered some opinions: 1) the San Diego Police Department estimated that $70 \%$ of all crimes committed in San Ysidro were perpetrated by undocumented persons. Citywide, the data indicated that $10 \%$ of the total crime was committed by the migrant population (not necessarily undocumented) and $5 \%$ of violent crime was committed by the migrant population--an extensive portion of this crime was committed migrants against migrants; 2) the Beta Group reported that $20 \%$ of the undocumented persons who are voluntarily returned to México reported abuses against them in the United States with the 
majority of those abuses committed by border bandits. Twentythree percent reported being assaulted by a member of the United States Border Patrol. A broadly based opinion existed that abuses of undocumented persons were occurring in the contact, detention, and voluntary deportation process. The San Diego Police Department was not identified as a source of abuse; and 3) the creation of the Beta Group had significant impact on the reduction of violence against undocumented persons at the border zone. 122

The subcommittee made several recommendations to the full Committee. A couple of those recommendations were: a) the creation of specific programs for education, intervention, and counseling at all levels of the undocumented population and San Diego's general population; b) a course of action which would continue cooperation with Méxican government (Beta Group and Border Youth Project and the like); and c) improvement in statistical gathering activities including documenting contacts of undocumented persons, after probable cause. The subcommittee suggested that the San Diego Police Department's policy of no police involvement in contact, identification, and voluntary return to México of undocumented persons may have to be re-examined by the San Diego Police 
Department.

The Committee concluded its investigation by reporting that the vast majority of undocumented persons enter the United States without any intent to become involved in violent crimes, however, initially non-violent crimes cannot be ignored as they can develop into violence easily. 123

The San Diego Police Department policy regarding the handling of undocumented aliens (dated December 20, 1987, Patrol 6.18) was restrictive to the officers, it read in part:

Officers, while conducting a criminal investigation, determine that a person is an undocumented alien the following shall apply: a) if there is cause to arrest on a criminal charge or otherwise detain in a lawful manner, for reasons not related to immigration status, the officer will do so; and b) in all other cases the officer(s) will release the subject at the point of contact. Detention for release to border patrol is prohibited.

Chief Jerry Sanders made a commitment to improve relations/ partnerships with the community, while enforcing the laws. Consequently, when the need came to revise the Undocumented Person Policy, several community members were part of the policy making committee. The revised Undocumented Person Policy was improved and training was offered to all officers on how to use the new policy. The new Undocumented Person Policy reads in part: 
San Diego Police officers are responsible for the enforcement of all laws, federal, state, and local, and the safety and protection of all persons. Officers have a duty to contact any person(s) when there is a reasonable suspicion to believe they are involved in criminal activity.

If probable cause to arrest exists, unrelated to the person's immigration status, officers may arrest for the offense and place an immigration hold for Border Patrol. In addition, if no probable cause to arrest exists but there is reasonable suspicion that criminal activity still exists, officers can take action. If the detainee is in violation of 8 United States Code Section 1304 (e), officers are authorized to notify INS/Border Patrol and release the subject at the scene of the contact, within a reasonable time (20 minutes). 124

This new policy allowed San Diego Police officers to work in a partnership with the community and still detain those undocumented persons found involved in criminal activity. Records were kept on the actual statistics of criminal involvement by undocumented persons. Since the San Diego Police Department began gathering data in February 1994, undocumented criminals have been involved in a number of felony and misdemeanor crimes. Both male and female undocumented suspects have been arrested or detained by San Diego Police Department officers.

These figures indicated that not only were undocumented 
Latinos arrested or detained; but, there were undocumented persons from other countries arrested or detained. The number of undocumented males arrested accounted for $91.7 \%$ while the females reported at $8.3 \%$. These figures represented the number of acutal arrests or detentions. The number of undocumented persons that were contacted and released in the field are not listed here.

5. Total break down by race, sex, and age of arrest/ detention of undocumented persons, 1994.

Arrests:

\begin{tabular}{|c|c|c|c|c|}
\hline $\begin{array}{c}\text { Race } \\
\text { Latino / Other }\end{array}$ & $\begin{array}{c}\text { Sex } \\
\text { Male/Female }\end{array}$ & $\begin{array}{l}\text { Age } \\
<18 / 18>\end{array}$ & $\begin{array}{l}\text { Totals } \\
\text { Undoc. }\end{array}$ & $\%$ undocu. \\
\hline $1,105 \quad 33$ & $1,044 / 94$ & $70 / 1,063$ & 1,138 & $2.5 \%$ \\
\hline
\end{tabular}

Detentions:

Race Sex Age Totals

Latino / Other Male/Female <18/18> Undoc. \% undocu.

$3,270 \quad 14 \quad 3,098 / 182 \quad 151 / 3,129 \quad 3,280 \quad$ n/a

Source: San Diego Police Crime Analysis Unit, 1994.

When these figures are compared with the total number of persons booked for 1994 , there were 46,027 persons arrested and booked, with the number of undocumented persons accounting for about $2.5 \%$ of the total number of persons arrested. Undocumented juveniles, under the age of 18 years, were also involved in criminal 
activity. As these figures indicated, there were 221 juveniles

arrested or detained for criminal conduct.125

The Beta Group: 1990 - 1994

In the early 1990s, Méxican federal authorities identified three different dimensions of violence in the area along the U.S./México international border: 1) actions committed against Méxican nationals by Méxicans in México territory; 2) acts of violence against Méxicans-mostly undocumented migrants--on the United States side of the border by non-governmental actors; and 3) "institutional violence" on part of U.S. authorities against Méxican citizens--mostly undocumented migrants. As a result, México created the Beta Group in June, 1990. This team consisted of thirty police officers chosen from local, state, and federal agencies, placed under the direction of the Méxican Under-Secretary of the Interior, Miguel Limón. Mr. Limón was tasked with fighting criminal delinquency on the Méxican side of the border concerning border bandits.

Méxican authorities down-played the collaboration between the United Stateas and México because of political reasons. As a result, when incidents of violence dropped in 1991, Méxican officials had to content themselves with watching the U. S. Border Patrol 
claiming credit for the reduction of crime. The U. S. Border Patrol argued that the positive results were due to new strategies on their part aimed at channeling potential undocumented migrants towards points where they were better able to control them by improved lighting in certain areas and the reinforcement of "the fence" with air force surplus landing mats. 126

Unlike the Border Crime Intervention Unit (BCIU), officers from the Beta Group worked in plain clothes, they blend among the migrants, watched for delinquents and arrested those individuals involved in criminal activity. The San Diego Police Department's, executive officer, second-in-command at the Southern Division, in San Ysidro, referred to the relationship between BCIU and the Beta Group Beta Group as, "One of the greatest working relationships between law enforcement in two different countries." Before the BCIU and the Beta Group were in place, when San Diego Police officers would chase suspects along the border, the suspects would simply run across the border and escape into México. Now, when suspects run across the border, the Beta Group is there waiting for them. And if the Beta Group officers chase a suspect north across the border, members of BCIU are waiting for him/her.127 
In July 1990, Javier Valenzuela was the Beta Group's commander. Mr. Valenzuela was a university-trained psychologist who was new to law enforcement. Mr. Valenzuela stated in an interview with the San Diego Union, "we're going to be neighbors (with the United States) all of our lives, so we have to take care of the neighborhood."128

Under the direction of Mr. Valenzuela, the Beta Group evolved into an internationally acclaimed border task force that reduced violence along the San Diego/Tijuana international border, improved relationships with the United States and largely resisted the corruption that plagues Méxican law enforcement. But in December 1992, Mario Arturo Coutino took over as "top-cop" in charge of the Beta Group replacing Javier Valenzuela, who served until November 1992.129 Some observers worried about the future of the Beta Group following Valenzuela's departure.130

The new Beta Group administration suspended the monthly joint training sessions with the Border Crime Intervention Unit, a San Diego Police tactical squad that had developed a close rapport with the Beta Group. According the Los Angeles Times, a San Diego Police official stated, "It's a safety issue. It creates an atmosphere for an 
incident that could lead to serious consequences."131

The new Beta Group commander was also re-examining their relationship with United States law enforcement agencies. Coutino was quoted in the Los Angeles Times, with regards to the relationship that existed between BCIU and the Beta Group as, "It must be clear that Beta is a Méxican force. It had reached a point where we were a complement of the agencies of our neighbors... We should develop a concrete agenda, demarcating clearly our functions."132 With respect to the changes in the Beta Group, Victor Clark Alfaro, director of the Bi-national Center of Human Rights said, "These are the kinds of changes that always happen in politics: A new leader brings in his own people."133

In October 1993, Mr. Coutino was replaced by Hugo Ayala Morales. Mr. Ayala took over as the Beta Group's commander in November 1993, and served in that capacity until February 1995.134 In February 1995, Alejandro Olea Garcia was selected as Mr. Ayala's replacement. Mr. Olea became the fourth commander of the Méxican task force, the Beta Group. Since its founding, the Beta Group has been headed by federal civil servants from México's Immigration Office, usually men with academic backgrounds.135 Alejandro Olea 
was expected to bring physical training and state-of-the-art technology to the Beta Group.

The Beta Group's operation is unique because of the incredible amount of cooperation between México and the United States. This cooperation has developed into a partnership between $\mathrm{BCIU}$ and the Beta Group. Both units met and exchanged information on a daily basis, each unit has the other unit's radio frequency--thus they were able to communicate rapidly as events were unfolding at the border, whether it was a border bandit fleeing south across the border into México or vice versa.136

In addition to daily meetings which were held between officers from $\mathrm{BCIU}$ and the Beta Group, each month BCIU and Beta Group officers held firearms training sessions together. A close bond formed between these officers. Consequently, this bonding resulted in mutual respect between the two groups. Key to this trust was the elite nature of the Beta Group officers. The officers were screened and selected with anti-corruption in mind. In addition, Beta Group officers were paid considerably more than their colleagues and corruption was not tolerated within the Beta ranks. Members of the BCIU team were impressed by the quality of the Beta Group officers 
and felt that corruption was non-existent within the Beta Group at that time. 137

Since the beginning of the Beta Group's operation, they have collected statistical data from their investigations and citizen's complaints. The crime statistics for the reported border crime in México for 1990-1994 was as follows:

6. Beta Group Statistics for 1990 through 1994:

Beta Group Statistics:

\begin{tabular}{|c|c|c|c|c|}
\hline Year & Murder & Rape & Robbery & Totals \\
\hline 1990 & 1 & 2 & 17 & 20 \\
\hline 1991 & 0 & 0 & 4 & 4 \\
\hline 1992 & 0 & 0 & 32 & 32 \\
\hline 1993 & 0 & 0 & 4 & 4 \\
\hline 1994 & 0 & 1 & 52 & 53 \\
\hline Total & 1 & 3 & 109 & 113 \\
\hline
\end{tabular}

Source: Méxican Law enforcement, Beta Group, 1995.

United States Border Patrol (USBP):

The United States Border Patrol (USBP) was a key element in the efforts of BCIU and the Beta Group. Without the assistance of the 
United States Border Patrol, neither team would have obtained the results which they did.

The U. S. Border Patrol was a mobile, uniformed, enforcement arm of the Immigration and Naturalization Service (INS). The Border Patrol had its beginnings in 1904, when the Commissioner General of Immigration assigned a small group--never totalling more than 75-to protect the southern border on horseback. As immigration was tightened over the years, more and more immigrants tried to enter the U.S. illegally. In response, the Bureau of Immigration reorganized in 1924, the small border guard into the Border Patrol. In 1925, the Border Patrol was given authority for coastal operations and in 1926, the Border Patrol was reformed and expanded to better deal with the problem of illegal entries. 138

The primary mission of the Border Patrol was the detection and apprehension of illegal aliens and smugglers of aliens at or near the land border. Other activities included maintaining traffic checkpoints along highways leading from border areas, conducting city patrol and transportation checks, and anti-smuggling investigations. Since 1986, the Border Patrol has apprehended more than 8 million aliens nationwide. 139 
XXX. United States Border Patrol Agent Leo Calderhead searching for illegal aliens at the San Diego/Tijuana international border, September 27, 1962. San Diego Historical Society, Photograph Collection. 


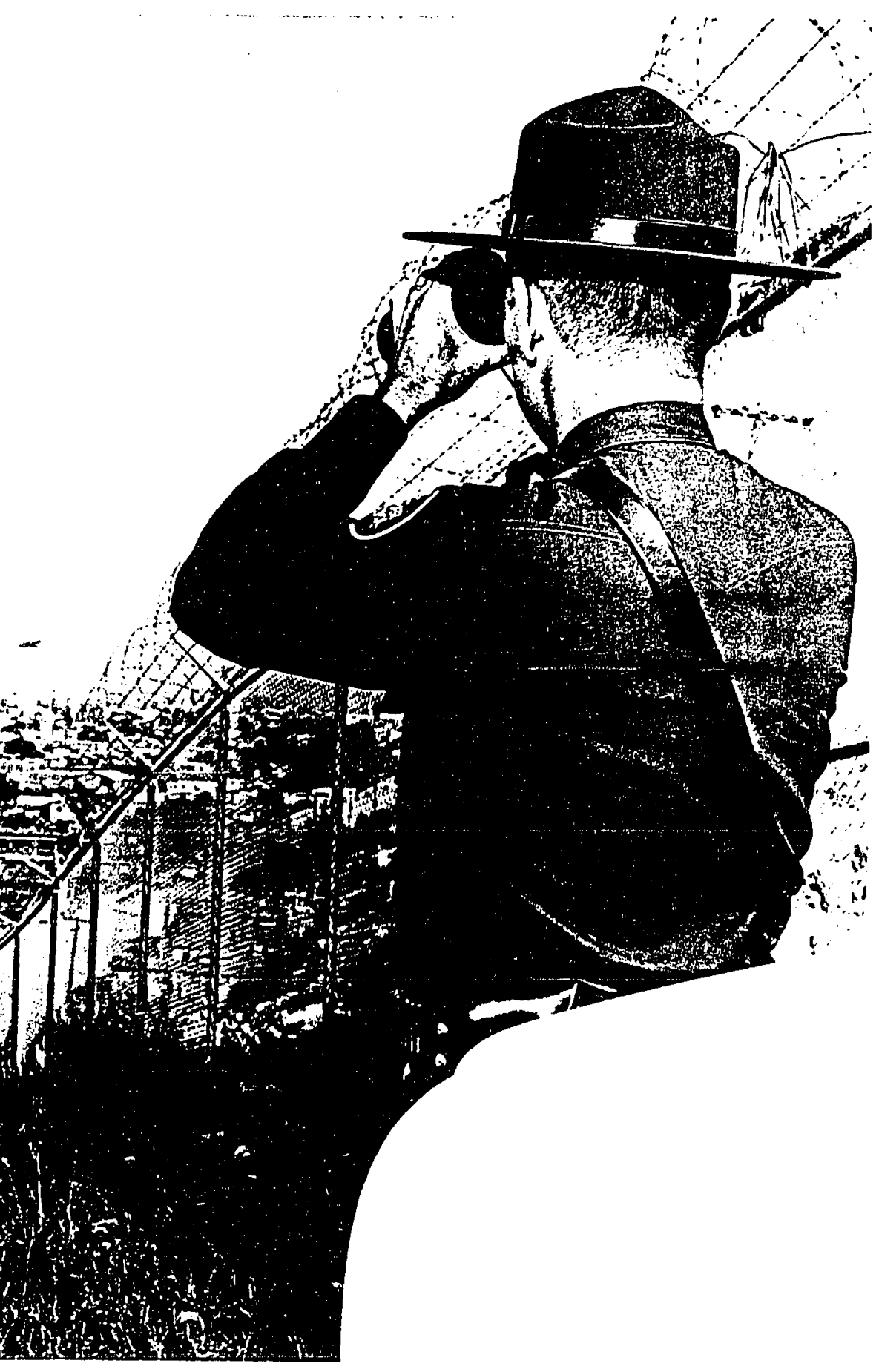


In 1992, the Office of National Drug Control Policy granted the Border Patrol dual responsibility of protecting the borders against narcotics and other contraband, and for enforcing the immigration laws. This crossdesignation has reinforced the Border Patrol's role as the front line of defense against drug smuggling and criminal aliens. The San Diego Border Patrol Sector encompasses over 7,000 square miles, including all of San Diego County and substantial portions of Orange and Riverside Counties, and shares 66 miles of international boundary with the Méxican state of Baja California. Tijuana, Baja California, México, with its growing population has approached the two million resident mark. The Méxican city of Tecate, a smaller city of 50,000 residents, borders the United States in the San Diego Border Patrol Sector's area of responsibility.

Each year, the United States Border Patrol agents from the San Diego Sector apprehend undocumented aliens from over 60 different nationalities worldwide. Historically, the San Diego Sector of the Border Patrol has been the most active region for the Border Patrol operations, accounting for $40 \%$ of the Nation's apprehensions and in recent years, $50 \%$ of all apprehensions recorded along the southern border. 140 The total number of undocumented alien apprehensions 
in the San Diego Sector are as follows: $1+1$

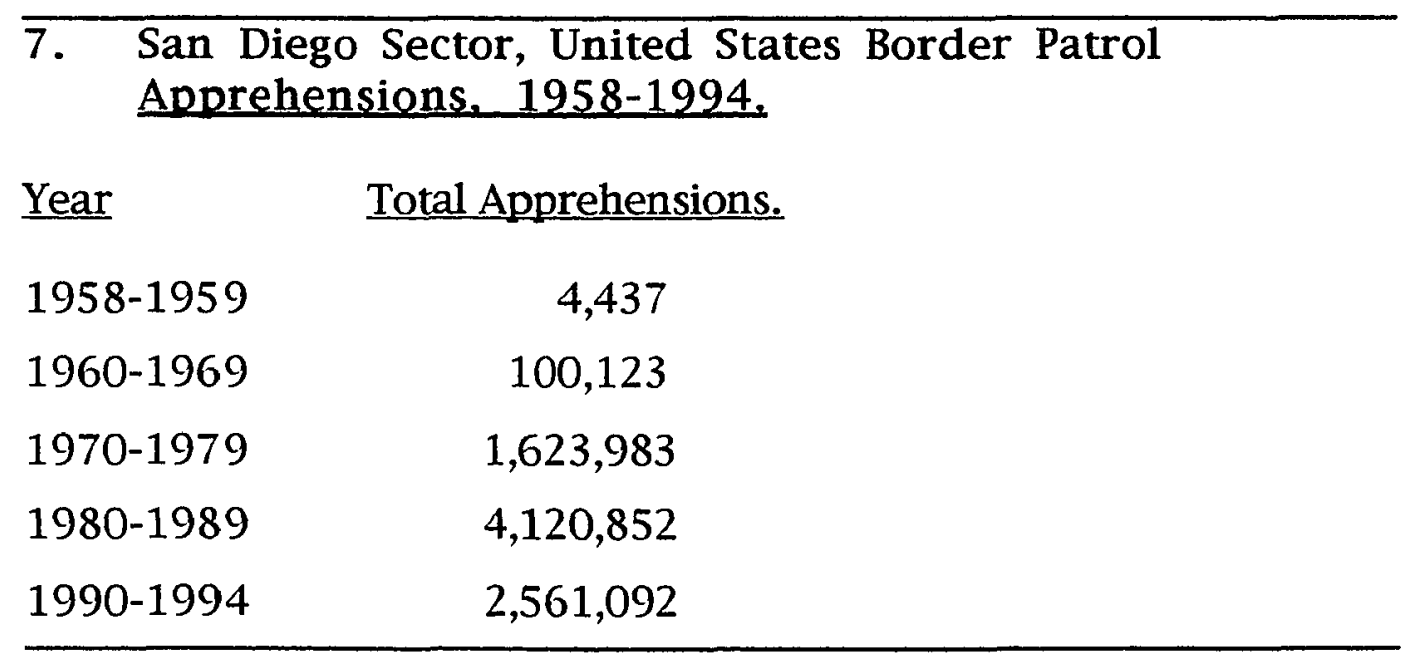

Source: U. S. Border Patrol, San Diego Sector, 1995.

The following is a record of the value and size of drug seizures in the San Diego Sector made by U. S. Border Patrol agents:

8. Value and size of drug seizures, $1981-1989 \& 1990-1994:$

San Diego Sector Border Patrol Drug Seizures:

\begin{tabular}{llc}
\hline Year & Wholesale value & Number of seizures \\
$1981-1989$ & $\$ 168,983,458$ & 1,691 \\
$1990-1994^{*}$ & $\$ 385,462,405$ & 3,860 \\
\hline
\end{tabular}

* Wholesale value of marijuana dropped from $\$ 1,000$ in 1992 to $\$ 800 /$ per pound in 1993.142

In an effort to deal with the problem of drug smuggling and alien smuggling, the federal government began to install powerful floodlights along the four-mile stretch of the San Diego/Tijuana 
border, west of the San Ysidro Port of Entry. Military workers began installing 45-foot high, steel covered light poles, some about 150 feet north from the international border, where a steel fence was first erected three years prior. The lights were strategically placed along a four mile area that extended from Dairy Mart Road to Goat's Canyon, near the Pacific Ocean. The lights were meant to augment a 10-foot high steel fence that extended 14 miles from the Pacific Ocean to the Otay Mountains. 143

Not all of the undocumented persons who cross into the United States are criminals; however, there are segments of this population which are prone to criminal activity. Although problems presented by criminal aliens can only be addressed by the federal government, criminal aliens who are incarcerated in state and local facilities have become a major issue for those entities. Many people are concerned with the impact criminal aliens have over the criminal justice systems, and the costs to the state and local governments of incarceration. 144

The California Department of Corrections (CDC) estimated that, as of December 31, 1993, there were more than 18,000 "deportable aliens" in California prisons, about 14\% of the total CDC prison 
population. The costs to California was estimated at $\$ 409$ million for fiscal year 1994/1995, which included the cost of incarcerating and paroling deportable criminals in CDC and the California Youth Authority (CYA) facilities, at about $\$ 22,000$ per prisoner per year.145

The California Youth and Adult Correctional agencies estimated in early 1993, an annual cost of $\$ 56.2$ million for incarceration of 3,325 convicted undocumented persons in California county jails. They also estimated a total of 6,971 undocumented persons in county jails in 1992, which represented a $9 \%$ of the total inmate population.

The 1992 Auditor General report on undocumented immigrants in San Diego County (Rea \& Parker Study) indicated thai the total annual criminal justice system costs for undocumented immigrants in the County exceeded \$105 million.146

The Rea and Parker study, however, has been criticized by other researchers for lack of reliability because of its methodological weakness. Daniel Wolf testified before the Assembly Select Committee on California-México Affairs in early 1993, and stated that the Rea and Parker report "overestimates by as much as 250 percent the number of undocumented immigrants processed by the criminal justice system, therefore, overestimates the costs by $\$ 90$ million." 147 
After serving their criminal sentence, the undocumented criminal aliens are subject to deportation procedures. If the INS determines that the deportation is warranted, the criminal alien will be returned to his/her country of origin, provided the United States has a treaty with the home country by which each country agrees to accept the other's deportee. The United States also has a "Transfer Treaty Program" by which criminal undocumented persons can be transferred to their home country to serve their sentence.148 Operation Gate Keeper (October 1994 - Present):

On October 1, 1994, the United States Border Patrol launched a special operation targeting illegal aliens crossing through the 14 mile stretch of border from the Pacific Ocean to the Otay Mesa.

About 150 additional United States Border Patrol agents were assigned to the San Diego Sector region, because this was the region where Border Patrol agents made most of their 500,000 annual apprehensions. Gustavo De La Viña, Chief of the Border Patrol at the time, was quoted as saying, "For the first time, we'll be able to take a look at this portion of the border and tie everything together--which means lights, fencing, technology, new equipment, and new personnel."149 
Because of the proximity to México, many of the undocumented people apprehended in the San Diego Sector came from the northern borders of México. Tijuana Baja California, México, was the main point for border crossing, within the San Diego Sector region. "Operation Gatekeeper" was developed to impact the flow of illegal alien crossing along the San Diego/Tijuana international border.

The data of apprehensions during "Operation Gate Keeper" for the San Diego Sector (limited to the Chula Vista, Imperial Beach, and Brown Field Stations) of the US Border Patrol is listed below: 150

9. Total number of U. S. Border Patrol apprehensions made since the start of Operation Gatekeeper, October 1994 to April, 1995.

\begin{tabular}{|c|c|c|c|}
\hline Month & ${ }^{*} \mathrm{IMB}$ & ${ }^{*} \mathrm{CHU}$ & *BRF \\
\hline $10 / 94$ & 12,048 & 4,414 & 5,884 \\
\hline $11 / 94$ & 5,814 & 2,954 & 4,482 \\
\hline $12 / 94$ & NA & NA & NA \\
\hline $01 / 95$ & 8,268 & 11,638 & 12,511 \\
\hline $02 / 95$ & 8,187 & 14,875 & 18,834 \\
\hline $03 / 95$ & 7,647 & 20,025 & 22,130 \\
\hline $04 / 95$ & 11,348 & 16,167 & 15,279 \\
\hline
\end{tabular}


These three Border Patrol stations were within the target of this project. The other stations of the San Diego Sector of the Border Patrol were not within this region and, therefore, those figures are not listed.151 Legal immigration fluctuated in the 1980s and 1990s. 10. United States Legal Immigration, 1989 to 1992. Legal Immigration into the United States

$\begin{array}{lccll}\text { Region } & \underline{1989} & \underline{1990} & \underline{1991} & \underline{1992} \\ \text { All regions } & 1,090,924 & 1,536,483 & 1,827,167 & 973,977\end{array}$

Country of birth:

México

El Salvador

Guatemala

Dominican Rep.

Philippines

Vietnam
405,172

679,068

$946,167 \quad 213,802$

57,878

80,173

$47,351 \quad 26,191$

19,049

32,303

25,527

42,195

$41,405 \quad 41,969$

26,723

57,034

63,756

$63,596 \quad 61,022$

37,739

48,792

$55,307 \quad 77,735$

Source: U. S. Border Patrol, San Diego Sector, 1995.

México ranked number one in the number of legal immigrants admitted into the United States with $37 \%$ in $1989 ; 44 \%$ in $1990 ; 52 \%$ in 1991; and 22\% in 1992.152 Latin America, which includes México, Caribbean, Central America, and South America, ranked at $60 \%$ in 
$1989 ; 67 \%$ in $1990 ; 70 \%$ in 1991 ; and $44 \%$ in 1992.153 Compared to Europe which was at $7.6 \%$ in $1989 ; 7.3 \%$ in $1990 ; 7.4 \%$ in 1991 ; and $15 \%$ in 1992 . Southeast Asia showed $28.6 \%$ in $1989 ; 22 \%$ in 1990 ; $19.6 \%$ in 1991 ; and $36.6 \%$ in 1992.154

The Immigration and Naturalization Service (INS) closely monitors the acts of violence involving Border Patrol agents that occur along the United States and México border. As of May 29, 1990, Border Patrol agents were involved in 189 physical assaults, including 37 assaults with firearms which did not result in the agent firing his/her weapon. During this same period, Border Patrol agents were involved in 30 shooting incidents, eight of which were drug related. The vast majority of these acts of violence on the Méxican border can be attributed to a particular segment of the alien population, which has increased significantly in the past few years. This population was composed of young, unemployed individuals. These individuals were responsible for the assaults, robberies, rapes, and other crimes against their own people.

The INS reported that a related factor to these crimes was the proximity of the border, which allowed a safe refuge to the perpetrators and, therefore, encouraged these types of violent acts. 155 
As previously stated, the enforcement at the international border was the obligation and responsibility of the federal government. Proposals such as imposing a border-crossing fee, or using the military to enforce the San Diego/Tijuana border can only be addressed by Congress. At the state level, it has been suggested that the California National Guard be deployed to assist the U. S. Border Patrol in the enforcement of the San Diego/Tijuana border. However, Gustavo de la Vina, Chief of the U. S. Border Patrol at San Diego, who testified before the Assembly Select Committee in San Bernardino, reported that border enforcement was a "tremendous job which requires extensive training." He suggested that the National Guard be used as a "support mode," which included construction and clerical support personnel. The California National Guard agreed with Chief De la Vina that their troops were not trained for border enforcement duties. Furthermore, the California National Guard was constrained from participating in any kind of law enforcement activity regarding illegal immigration. 156

The Immigration and Naturalization Service was committed to reducing and preventing border violence. To this end, they worked to improve joint cooperations on the Southwest border between both 
the United States and México governments. This included mutual exchange of information, liaison, and provided more uniformed personnel to patrol the border. In addition, equipment and technical support was provided to this region. 157

The United States Border Patrol, in addition to its dual responsibilities of controlling illegal alien crossings and drug interdiction, has been involved with the San Diego Police Department in the prevention of border violence along the international San Diego/Tijuana border. In the 1970s, five Border Patrol agents were assigned to work with the Border Alien Robbery Task Force (BARF); in the $1980 \mathrm{~s}, \mathrm{U} . \mathrm{S}$. Border Patrol agents were involved in a partnership with the Border Crime Prevention Unit; and most recently, in the 1990s, a United States Border Patrol supervising agent was assigned as a liaison between the Border Crime Intervention Unit (BCIU) and the Beta Group.158

The U. S. Border Patrol Supervising Agent has taken the role of a BCIU member with respect to his/her involvement with the BCIU team. The liaison Border Patrol agent participated in the BCIU training sessions, meetings, and missions. The supervising agent was key to the collaboration with the Méxican officials, the Beta Group.159 


\section{Summary}

The foregoing pages presented a discussion of the following: the history of the San Diego Police Department from 1957 to 1994; minority and female San Diego Police officers 1878-1994; Border Crime Task Force (BARF) 1976-1978; Border Crime Prevention Unit (BCPU) 1984-1988; Border Crime Intervention Unit (BCIU) 19891994; recommendations of the Blue Ribbon Committee on violence 1991; México's law enforcement Beta Group 1990-1994; and the United States Border Patrol 1904-1994.

The San Diego Police Department established the Division of Southern Operations in 1957, when the City of San Diego annexed twenty-two square miles along the international border, creating South San Diego.160 During this period, the San Diego Police Department operated a check point at the entrance to Tijuana in order to keep juveniles, without written permission from their parents or legal guardians, from entering México.161

Late in 1962, a new police substation was built in San Ysidro, close to the international border, for the Southern Division personnel.162

In January, 1962, Chief Adam Jansen retired after serving 
twenty-nine years and ten months.163 On January 8, 1962, Wesley S. Sharp, was appointed as Chief of Police (January 8, 1962 to January $3,1968)$. When Chief Wesley Sharp took office, he recognized the need for improving police/community relations and assigned a captain to study the feasibility of establishing a community relations program for the Department.164 He assigned Lieutenant Homer Johnson and Sergeant Bill Kolender as the first full-time community relations officers. 165

Chief Sharp also created the Internal Affairs Division; allowed police officers to wear short-sleeved shirts; and brought computer technology to the San Diego Police Department.166 Chief Sharp retired on January 2, 1968.

On January 4, 1968, Olif "Jimmy" Roed was appointed as the twenty-sixth Chief of Police. During his tenure with the Police Department, Chief Roed changed the color of the police cars from black and white to all-white. He also initiated the advanced officer training, the fleet safety driving and the store-front community relations programs. 167

On March 11, 1971, Ray Hoobler was appointed as the next Chief of Police. During the following five years, Chief Hoobler 
eliminated the mandatory wearing of the police safety helmet, which had been required since the late 1960s. Chief Ray Hoobler also created the Narcotics Task Force (NTF), and in 1975, closed the border check point which the Department had operated since 1957.168

On February 13, 1976, Bill Kolender was confirmed as the twenty-eighth Chief of Police for the City of San Diego. This was the first public confirmation hearing for a Chief of Police in the history of the San Diego Police Department. Chief Kolender was first appointed acting Chief when Chief Ray Hoobler resigned on September 9, 1975.169

Chief Kolender established a border task force along the international border at San Ysidro. The purpose of this task force was to provide police service along the United States and México border within the City limits. Although this task force was created in 1976 , the team was abolished two years later because of seven officer-involved shootings which resulted in the wounding of three BARF members and the wounding of seven Méxican Nationals.170 On September 19, 1988, Robert W. Burgreen was appointed Chief of Police, after serving two months as Acting Chief.171 Chief 
Burgreen supported the Border Crime Prevention Unit (BCPU); the México Liaison Unit; and the Neighborhood Policing Program.172

On May 17, 1993, Jerry Sanders was appointed Chief of Police.173 Chief Sanders reported, to the City Council, that he would make changes to enhance the Neighborhood Policing efforts and would assign officers to patrol particular communities rather than beats that cross traditional neighborhood boundaries. In addition, beats would be identified by community names and not by numbers, as they had been. Chief Sanders said the Department would work closely with diverse interest groups to determine to what extent its officers should cooperate with the United States Border Patrol in dealing with undocumented migrants. 174

In June 1993, Chief Sanders established the Neighborhood Policing Restructuring project for the purpose of developing a plan to realign the beat system, as he had promised during his confirmation. This project had four main goals: 1) to develop a plan to convert a beat system, from one based primarily on the census tract to one that was community based; 2) to incorporate problem solving procedures into all levels of the Department, and to all Department functions; 3) to reduce or eliminate any friction or gulf between the 
Neighborhood Policing Teams and regular patrol; 4) and to develop a team policing structure for all patrol forces. 175

The key recommendations which affected the border area were: the beat system restructuring and the undocumented person policy. The South Bay area of Southern Division was restructured as follows: 710s area of responsibility included the Tijuana River Valley and the community of San Ysidro. This area included the San Ysidro Port of Entry and the international border region. The second service area, 720s, included the communities of Egger Highlands, Nestor, Otay Mesa West, Palm City, and Otay Mesa- the secondary Port of Entry at Otay Mesa.176

Under Chief Sanders, the Border Crime Intervention Unit (BCIU) continued to work along the international border. The methods of operation for BCIU continued with the collaboration with the Méxican law enforcement agency known as the "Grupo Beta" (Beta group). 177

The undocumented person policy was changed, with input from community leaders, in order to allow the officers the flexibility to handle the criminal alien. The improved undocumented person policy was one of Chief Sanders' commitments during his confirmation. 
Minority and female officers first appeared in the San Diego Police Department in 1878 . Jose Cota was a constable in 1878 and came to the San Diego Metro in 1890. In addition, Chief Wilson appointed Joseph Lopez as patrolman on November 20, 1918, and later promoted Lopez to police lieutenant. Lieutenant Joseph Lopez retired in 1936.

The first African-American police officer was Reginald S. Townsend, who was appointed on January 1, 1915. On March 1, 1918, another African-American Officer, John Cloud, made police work his career. Officer Cloud gave the City of San Diego and the San Diego Police Department 22 years of his life. Officer Cloud retired from the Police Department on March 31, 1938.178

On December 4, 1911, the San Diego City Council passed an ordinance creating the office of the jail matron.179 The matrons did not have full peace officer powers and could only care for female prisoners, as custodial officers. 180 On January 19, 1912, the San Diego Police Department hired Rose Longacre. Rose served for only a few months before resigning on August 31, 1912.181 On December 19, 1912, Chief Jefferson Wilson appointed Ida Griffin as a police matron. Ida Griffin served until 1919, when she married Police 
Captain Arthur Hill, and resigned shortly thereafter. 182

The first policewomen were hired in 1918 , but could not hold their job. Lucille Jeardeaux resigned after three weeks of service and Mary Galvin was terminated within the first month of service.

In 1904, the Commissioner General of Immigration assigned a small group of officers to protect the Southern border on horseback-this was the beginning of the Border Patrol agency. In 1925, the Border Patrol was given authority for coastal operations, and in 1926, the Border Patrol was reformed to deal with the problem of illegal entries. In 1992, the United States Border Patrol was given dual responsibility of protecting the borders against illegal entries and narcotics smuggling. The Immigration and Naturalization Service was committed to reducing and preventing border violence and improved their cooperation with the San Diego Police Department's Border Crime Intervention Unit.

A border crime task force was created in 1976 and became known as the Border Alien Robbery Task Force (BARF). The goals of the BARF team were for officers to blend with the alien population, as they moved north from the border fence, and apprehend border bandits. The initial contact with the border bandits often resulted in 
armed confrontations between the officers and the bandits. In 1978, the special BARF team was concealed because of the extreme border violence. 183

In 1984 , the lack of law enforcement along the border became apparent as the number of victims began to escalate. The San Diego Police Department brought back the border team. The new border team was called the Border Crime Pervention Unit (BCPU). This team wore their police uniforms and worked in a high visibility profile. However, much like their predecessors, officers from BCPU were involved in a high number of officer-involved shootings. The violent nature and the physical environment of the border created a deadly situation for members of BCPU and the citizens of the area. As a result of the high number of border incidents, 35 shooting incidents, the San Diego Police Department pulled the BCPU from the hills after four years of service.

In 1989 , the border team was brought back to the hills. This team was called the Border Crime Intervention Unit (BCIU). The new border team was responsible for patrolling the 14 miles of border region within the City of San Diego's limits.

During the late 1980 s and early 1990 s, most of the border 
crime was occurring along the area known as the "South Levee." This area afforded the suspects an easy escape route either back to México or to the United States, depending on where the crime occurred. In mid-1990, the San Diego Police Department's SWAT joined the BCIU team and provided seven days a week coverage, specialized training for BCIU members, and later for the Beta Groūp. The training sessions offered basic firearms training, radio communiation techniques, and small unit tactics.

The relationship which the San Diego Police Department held along the international border with México's law enforcement agencies from 1957 to 1994 grew from poor to great. What became evident during 1957 to 1994 was the working relationship which was established between the Méxican law enforcement agencies and the United States law enforcement agencies. In the late 1970s, officers from the San Diego Police Department were invovled, at one time or another, in shootings with México's law enforcement officials who had crossed into the United States to commit crimes against helpless undocumented aliens. However, since the early 1990s, the San Diego Police Department Border Crime Intervention Unit (BCIU) began conducting training sessions and working collaboratively with 
law enforcement officials from México, the Beta Group.

On December 18, 1991, Chief Burgreen and the City Manager Jack McGrory, established a Blue Ribbon Committee on violence. The Committee made several recommendations, but the recommendation which impacted the border region dealt with improving the undocumented policy. The San Diego Police Department followed-up on this recommendation and developed a workable undocumented person policy which allowed officers to contact undocumented persons and release them to the United States Border Patrol, when less than probable cause to arrest was present.

Officers from the Méxican law enforcement Beta Group task force and the San Diego Police Department's Border Crime Intervention Unit met daily to exchange information on crime trends. These officers communicated over a special radio frequency and held monthly joint training sessions. In addition, supervisors from each team met monthly to discuss mutual interests and concerns. A close bond between BCIU and the Beta Group formed and resulted in mutual respect between law enforcement officals from both countries. 
XXXI. San Diego Police Officer, Ed Valentine, U.S. Border Patrol Supervising Agent Ben Monsivas and a second U.S. Border Patrol agent, members of the Border Crime Intervention Unit (BCIU), are debriefing local food vendors along the international border at San Ysidro/Tijuana border. Photo of Detective Carlos Medina (SDPD). 


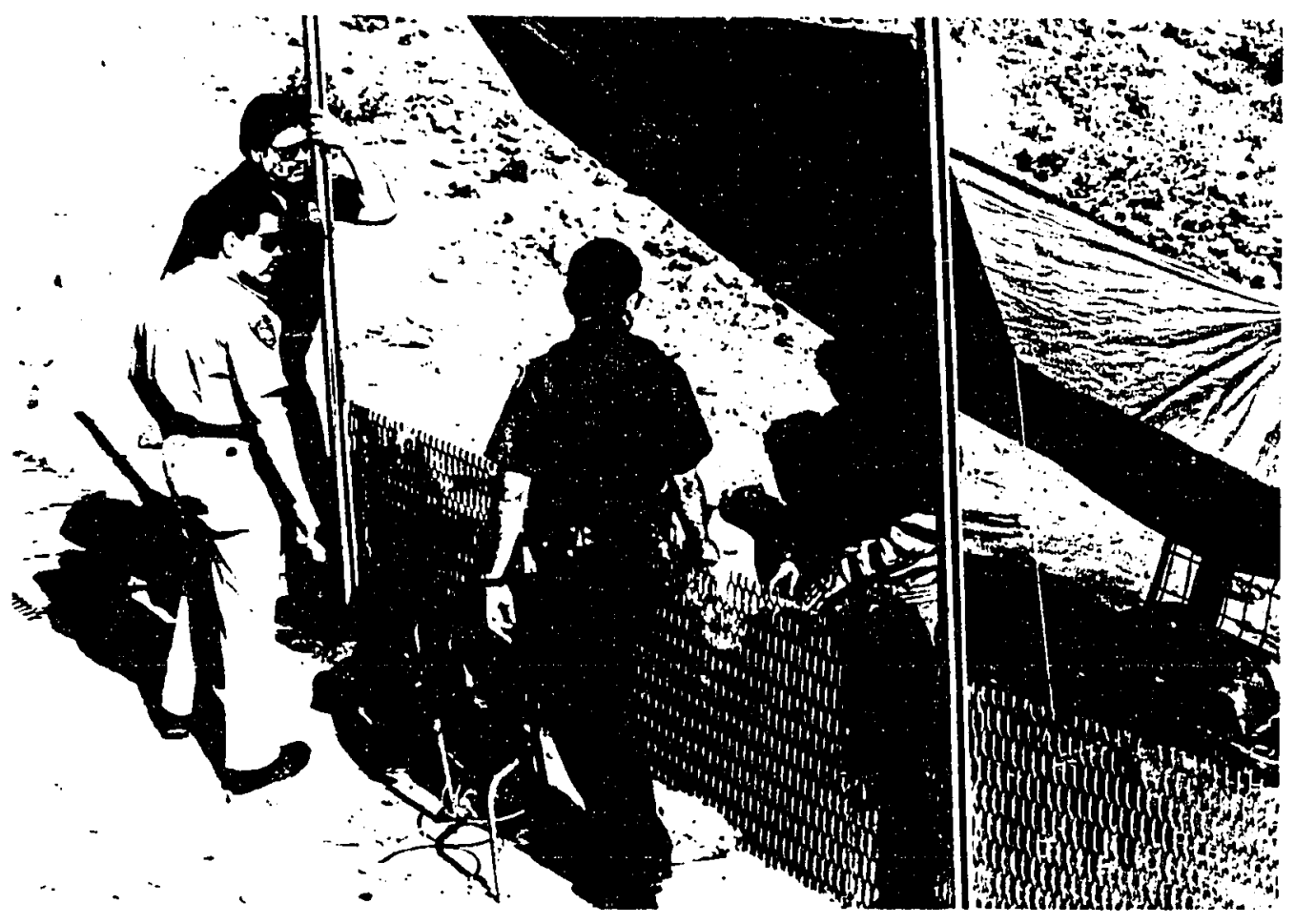


XXXII. A boundary marker located at the State Monument "Friendship" Park, at the Tijuana/San Diego border. In the background is the Tijuana's "Bull Ring by the Sea." Photo courtesy of Detective Carlos Medina (SDPD). 


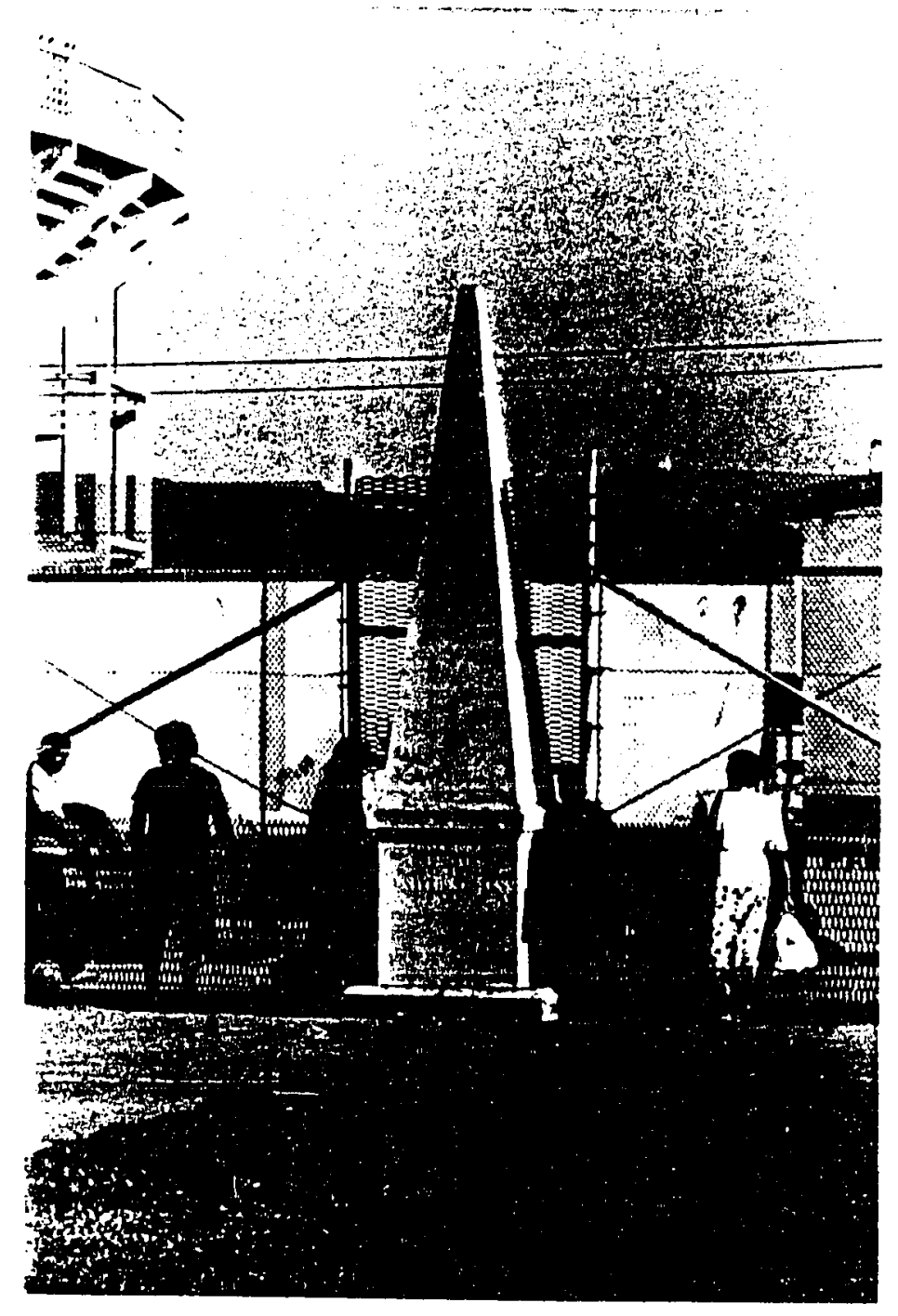


XXXIII. A group of Mexican nationals await on the United States side of the fence for an opportunity to get past the U.S. Border Patrol. Other people loiter on the Mexican side of the fence, awaiting their opportunity to cross into the United States. Aircraft landing mats were used to reenforce the fence. Photo courtesy of Detective Carlos Medina (SDPD). 


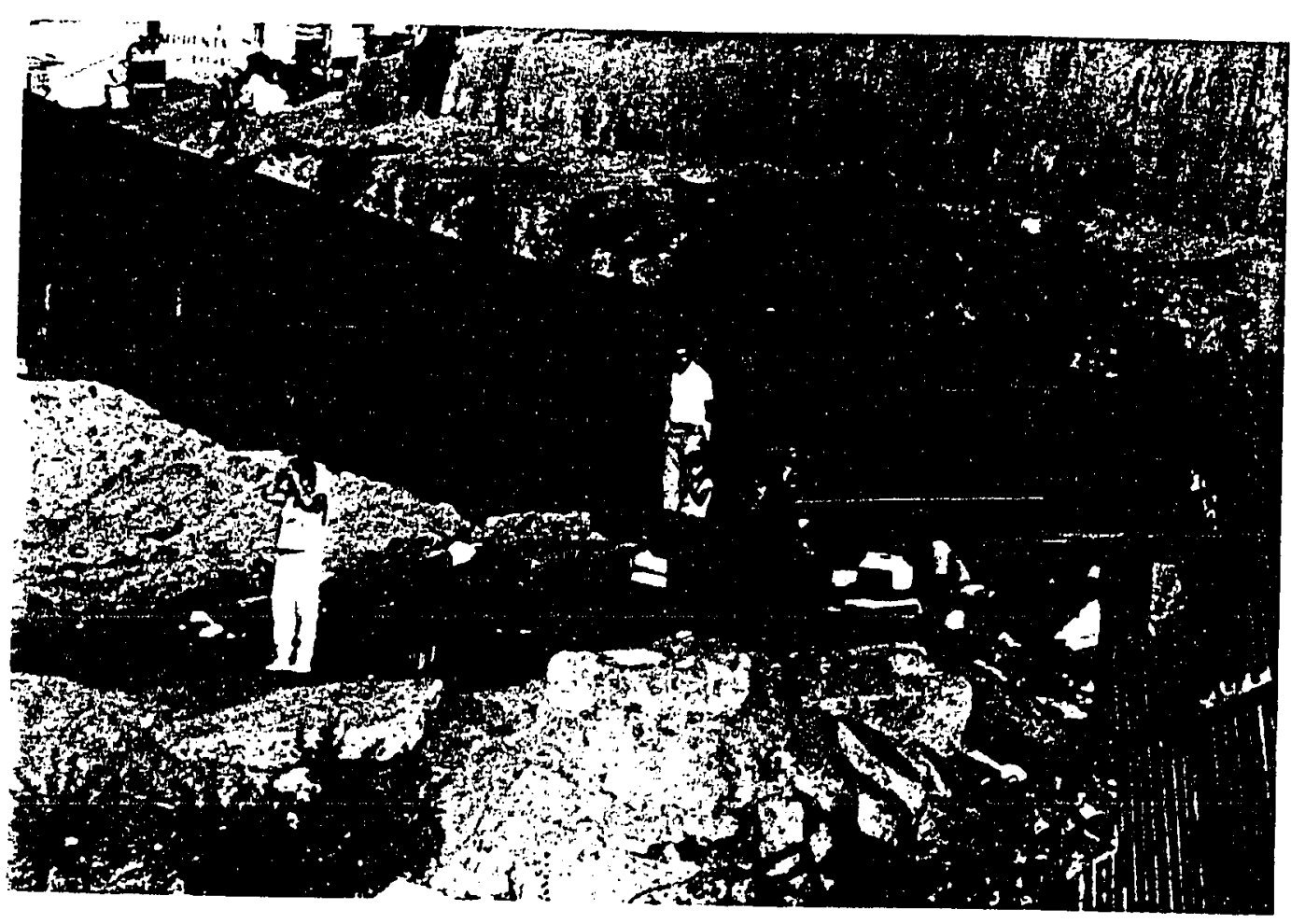


XXXIV. High intensive stadium lights along the levee at the San Ysidro/ Tijuana border. A number of undocumented persons wait in the shadows for an opportunity to get past the U.S. Border Patrol agents. Photo courtesy of Detective Carlos Medina (SDPD). 


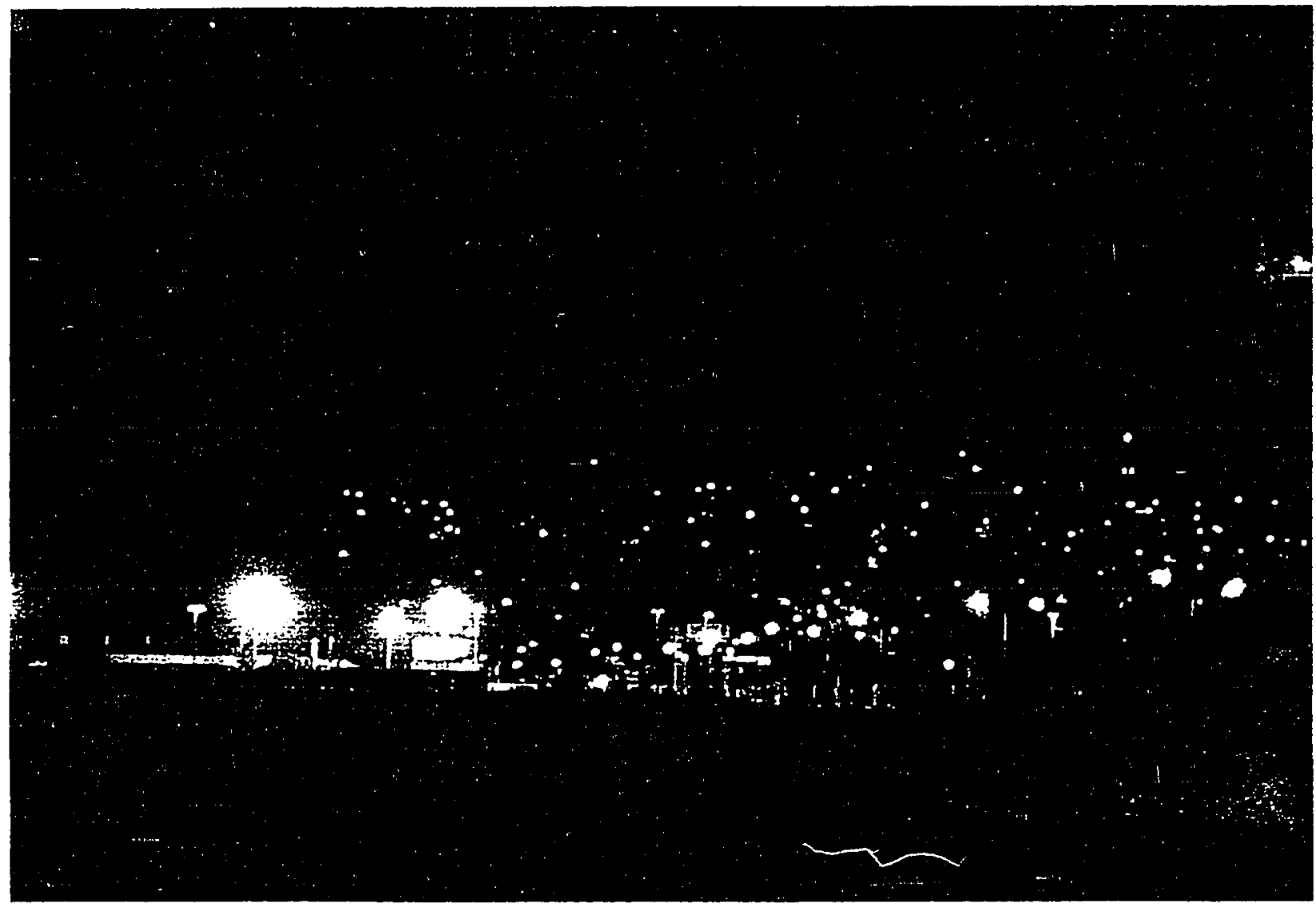


The San Diego Police Department Headquarters

building was built in 1938 at 801 West Market

Street. San Diego historical Society, Photograph

Collection. 





XXXVI Crowds watching the Battle of Tijuana from the border, c1911. San Diego Historical Society, Photograph Collection. 


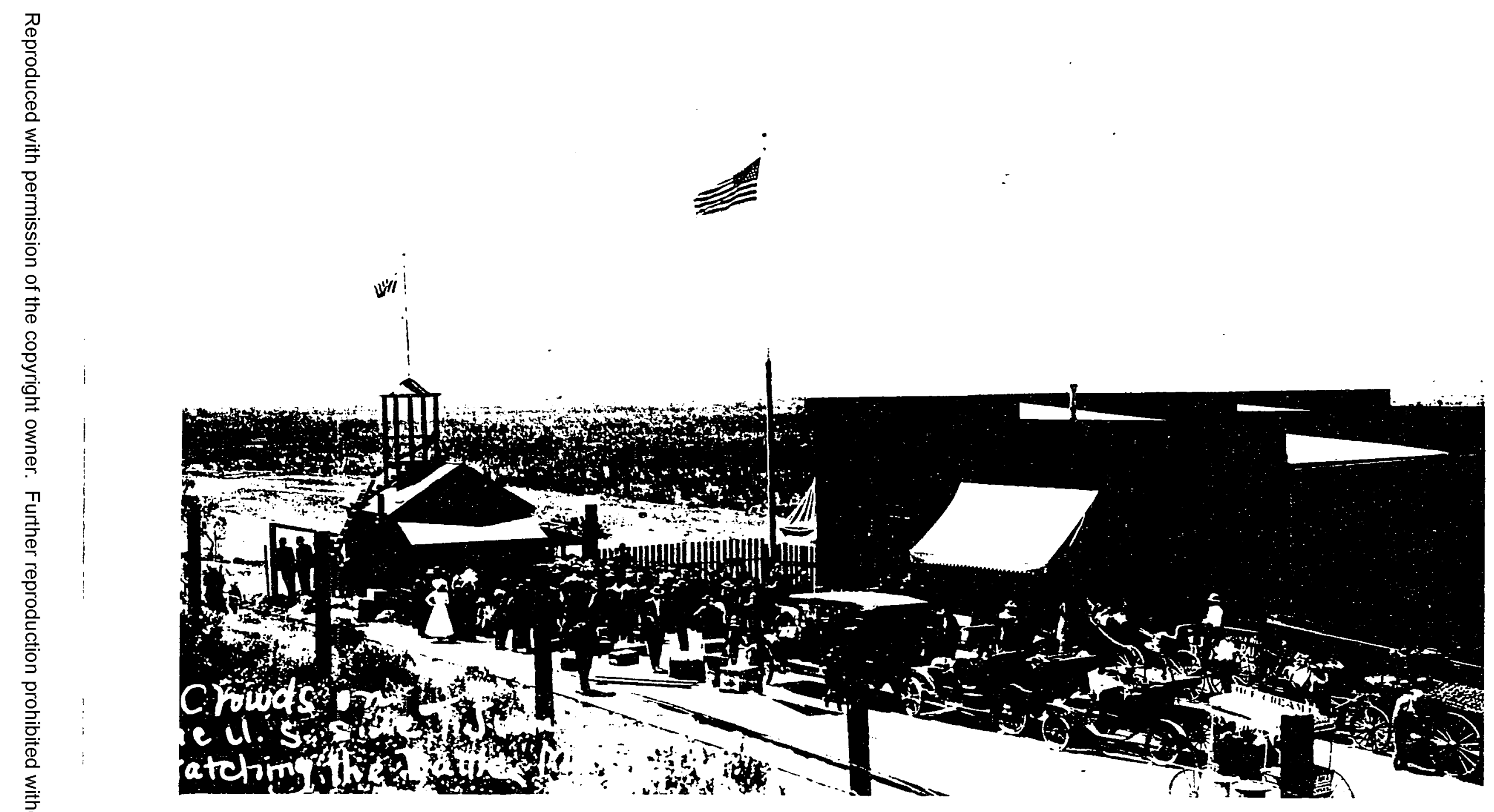




\title{
CHAPTER II
}

\author{
PART 2 \\ REVIEW OF THE LITERATURE
}

ENDNOTES

1. Price, op. cit., 10-11. Minors under twenty one years of age and over eighteen years of age are permitted to consume alcoholic beverages in México. México was an attractive place for the young adults to visit.

2. Ed Kennedy. "People ' $n$ things." The Informant Vol. 6, issue 11. December, 1986, 19. The Official publication of the San Diego Police Officer's Association. Ed Kenney retired from the San Diego Police Department.

The Police Department bought 1958 Ford sedans, which had heaters and the seats were a little more comfortable than the 1957 models.

3. Castanien, op. cit., 83

4. The San Diego Union, "Police division in South Bay makes record 527 arrests." February 10, 1958, A-14.

5. Officers from Central Division would drive down to Chula Vista at Interstate 5 and "E" street, to an area known as point seven. Southern Division officers would drive their prisoners to this area for the exchange and transfer. This policy continued for many years. This researcher, during the 1980 s would also transport his prisoners when assigned at Southern Division. This policy was discontinued because of the additional officers assigned to Southern Division and the increase of calls-for-service for Central Division officers. Today, Southern Division officers transport their own prisoners to headquarters for processing or to County Jail, Downtown San Diego.

6. Ibid. The officers from Southern Division made 527 arrests; 20 out of 323 adults arrested were South Bay residents. A total of 205 adults lived in the county and 98 lived outside of the county. South Bay officers received 694 radio calls, issued 1,165 moving citations, and issued 13 parking citations.

There were 60 investigations, 966 persons were interviewed, six stolen vehicles were recovered and 62 others were impounded. Property valued at $\$ 4,408$ was recovered during the first month of operation. In addition, officers investigated 21 non-injury accidents and seven accidents in which seven persons were injured and one was fatally injured. Twenty-five juveniles were arrested for runaway, 35 for curfew, 27 for felony charges, three for narcotics 
violations and 13 for misdemeanor charges.

Officer Owen Feuer delivered a baby for the first time in his police career.

7. San Diego Tribune, January 4, 1958.

8. Castanien, op. cit.17-82.

9. Ibid., 79-80.

10. Personal interview with Ron Collins. Ron provided the names of those past México liaison officers. June 2, 1995.

11. Castanien, op. cit., 82 .

12. Ibid., 83

13. Ibid., 84 .

14. Ibid., 87 .

15. Ibid., 87 .

16. Ibid., 87.

17. Ibid., 88 .

18. Ibid., 89 .

19. Gary Mitrovich. The Informant. Vol. 7, issue 11. December, 1987, 9. The official publication of the San Diego Police Officer's Association. By 1970, black-and-white police cars had vanished from the San Diego Police Department's fleet.

20. San Diego Tribune. February 4, 1971. A-4.

21. Castanien, op. cit., 90.

22. Ibid., 95.

23. Ibid., 94-96.

24. Castanien, op. cit., 97.

25. Ibid., 96.

26. San Diego Union. July, 11, 1975, B-1. "Police to end border check." 27. Ibid., 98. 
28. Joseph Wambaugh. (1984) Lines and Shadows. Bantam Books, New York: New York.

29. Castanien, op. cit., 107.

30. The Méxican liaison team consists of two San Diego Police officers working in México as liaison to San Diego Police Department and to other United States law enforcement agencies. This team works outs of the Criminal Intelligence office.

31. The official publication of the San Diego police Officer's Association. The Informant. Vol. 13, issue 2. March 1993, 12-13, \& 15.

32. Since 1889 to the present, 31 men have served as San Diego Chief of Police. Four men have also served as Acting Chief of Police.

33. San Diego Union, May 18, 1993, B1, B4.

34. San Diego Union, May 18, 1993, B4.

35. The Neighborhood Policing Restructuring Project consisted of 11 sworn and civilian personnel, lead by Captain Dave Bejarano from Southern Division. The steering committee had 14 assistants from throughout the department as technical support staff. The final report of the Neighbor-hood Policing Restructuring Project Committee was titled: Neighborhood Policing: The next generation.

36. Final Report from the Neighborhood Policing Restructuring Project Committee. Most of the 42 recommendations dealt with staffing practices, service delivery, and the new beat structure. Of importance to this study were the recommendations affecting the border region, with Southern Division as one of the first demonstration sites, with the second being Northeastern Division.

37. San Ysidro Port of Entry is the busiest border crossing in the world. The second Port of Entry was opened in Otay Mesa to assist with the commercial crossing. This Prot of Entry is only open during business hours, primaryily from 0600 to 2200 hours daily.

38. A. F. Lowenthal, \& K. Burgess. (Eds.). (1993). The California México connection. Stanford, CA: Stanford University Press, 349.

39. San Diego Union. December 11, 1991. "On the law's edge: Crack Méxican police team wages war on border crime." E-1 and E-3. Valenzuela did not like his officers being referred as Bandits. He shortened the name Bandit to " $\mathrm{B}$ " or BETA. Beta Group's goal was to make the area (border region) secured.

40. Notes taken from Pliny Castanien's note pad. This note pad consisted of type written notes concerning first minority hired by San Diego Police Department, no date listed on the notes. 
41. San Diego Police Department Commemorative Album, 1889-1986. San Diego Police Officer's Association.

42. San Diego Police Department Commemorative Album, 1889-1986. San Diego Police Officer's Association.

43. San Diego Union, May 29, 1964. Detective Sergeant Ritchey, 56 years of age, retired in 1964 after having served 28 years. He studied law at California Western University and received his doctorate degree in 1962. Ritchey earned a bachelor's degree in chemistry from the University of Southern California.

44. Anne F. Patton. The palm tree: The old-timer's corner. Up Front. A San Diego Police Department publication. June, 1984, 6.

Detective sergeant Bert Ritchey was involved in creating the police community relation storefront offices and the training in psychology of human relations.

45. San Diego Tribune. July 15, 1963. Chief Wesley Sharp said that the appointment had nothing to do with recent charges of racial discrimination leveled at the department by various African-American groups.

46. Within the San Diego Police Department, the African-American officers are able to join the Black Officers Police Officer's Association (BPOA).

47. Notes taken from Pliny Castanien's note pad, no date listed. These notes had the title of "First minority hiring SDPD." Castanien was the San Diego Police Department Historian, phone number 236-6281.

48. Ibid.

49. Samuel Walker, Professor of Criminal Justice, University of Nebraska at Omaha. Employment of Black and Hispanic Police Officers, 1983-1988: A followup study: Occasional paper: No. 89-1, February 1989. Center for Applied Urban Research, University of Nebraska at Omaha, Peter Kiewit Conference Center, 1313 Farnam-on-the-Mall, Omaha, Nebraska, 68182.

50. Professor Walker's study surveyed police departments in the 50 largest U. S. cities, 1983-1988. The cities were ranked by population according to the 1980 Census of the Population. The index measures percentage of minority employees compared to percentage of that minority group in the local population. Some agencies had African-American and Hispanic affirmative action plans and others had voluntary plans or court ordered plans.

For this project, the researcher only included Professor Walker's results for San Diego, African-American and Hispanic populations/officers. Please refer to Professor Walker's paper for complete details of his findings.

51. The official publication of the San Diego Police Officer's Association. The Informant. Vol. 12, issue 6. July 1992, 2. 
52. San Diego Police Department Personnel Division, 1994. The Latino and Hispanic officers are able to join the Latino Police Officer's Association or the Metropolitan Police Officer's Association. These organizations are set-up to assist officers in various aspects of their career, but are not the bargaining unit for the City. Any officer can join these organizations-membership is not limited to Hispanics or Latinos.

53. Wells was a graduate of a theological seminary in Connecticut and had worked in several church related social work positions before her appointment to LAPD. She felt that social workers engaged in preventive and protective work for women and children would achieve better social results if they had police powers. Wells addressed a petition signed by one hundred influential citizens and civic organizations, to the police commission and city council asking for an ordinance creating positions for policewomen. On May 17,1915 , the International Association of Policewomen was organized in Baltimore. Wells was one of the initiators and became its first president.

54. Peter Horne. Women in Law Enforcement. 2nd Ed. (1980) Charles Thomas Publisher, Springfield: Il. 26-33. Peter Horne is an Associate Professor at the St. Louis Community College at Meramec, Department of Criminal Justice.

55. Susan Martin. "Female Officers on the move? A status report on women in policing." In Critical Issues in Policing, ed. Dunham and Alpert. Grove Park, Ill.: Waveland Press, 1988, 32-33.

56. L. Higgins. 1961. Policewomen's Manual. Springfield. Il.: Charles Thomas Publisher and P. Horne. 1980. Women in Law enforcement. Springfield, Il. Charles Thomas Publishing.

57. Ordinance \#6311, section 6. Ordinance, City of San Diego, V. 20:20, can be found in the San Diego Historical Society Research Archives (SDHSRA). The Books of Ordinances are original; the entries are handwritten and listed in numerical order; and the volumes are handbound.

58. Although the matrons were sworn personnel, they did not receive guns or handcuffs, nor did they go out in the field.

59. Pliny Castanien, San Diego Police historian, said the Department routinely used policemen's wives to assist with female prisoners prior to the creation of the matron office. See San Diego Police Department 1889-1986, 36.

60. Civil Service Commission Minutes, 1919, 40. (CSC Minutes), City of San Diego Administration Offices, Sixth Floor, Downtown San Diego, Ca.

61. August Vollmer served as Berkeley's Chief of Police from 1906 until retirement in 1932. San Diego was the first of many surveys that Vollmer and his associates conducted over the years. Vollmer's professionalize policing and his reforms formed the backbone of modern policing. Gene E. Carte and Elaine H. Carte, Police Reform in the United States: The era of August Vollmer, 1905-1932. Berkeley University of California Press, 1975, 29. 
62. The Civil Service Commission called for policewomen-matron exams to be held on June 27,1918 , but so few women applied that the Commission told the City to advertise more. The City conducted the tests on July 11,1918 , but only 11 women participated in the process. Of those 11 who took the tests, only five passed. CSC Minutes, 1918, 54.

63. Resolution \#23736, v. $34: 300$, authorized the appointment of both women.

64. San Diego Police Department Commemorative Album, 1889-1986. San Diego Police Officer's Association.

65. Horne, op. cit., 26-33.

66. Le Bouef v. Ramsey, 26 FEP Case $884(9 / 16 / 80)$.

67. C.G. Stuart. 1975. Changing status of women in police professions. Police Chief, XLII (4): 61.

68. Catherine Milton. 1972. Women in Policing. Washington D.C.: Police Foundation.

69. Lesli Kay Lord. 1983. 'A comparison of male and female peace officers' stereotypic perceptions of women and women peace officers." A nonpublished Doctor of Philosophy in Leadership and Human behavior Dissertation. United States International University. San Diego: Ca. (pp. 86-88). Lesli Lord is now a Police Captain for the San Diego Police Department.

70. Ibid., 88.

71. D.J. Bell. 1982. Policewomen: Myths and reality. Journal of Police Science and Administration, $10(1): 112-120$.

72. Ibid.

73. Castanien, op. cit., 96.

74. The San Diego Union, April 7, 1974. B-8.

75. Anne F. Patton. Women Officers of the San Diego Police Department, 19121988. A Thesis submitted to the University of San Diego for the degree of Master of Arts in History, 1989. University of San Diego: Ca.

Information came from an interview with Chief Kolender by Patton on November 3, 1988, and from statistical information provided by Officer Matt Weathersby, SDPD Public Affairs.

76. Marce Hanson. The Informant. Vol. 13, issue 10. November 1993, 1415. The official publication of the San Diego Police Department. Hanson is a Special Interest Editor for The Informant. She is also a former San Diego police officer, medically retired Deputy Marshal and freelance writer. 
77. The San Diego Union, July 24, 1981, B-2. "Police get first women lieutenant."

78. Donovan Jacobs. The Informant. Vol. 14, issue 5. June 1994, 16-17 \& 19. The official publication of the San Diego Police Officer's Association.

79. Marce Hanson. The Informant. Vol. 13, issue 10. November 1993, 14-15. The official publication of the San Diego Police Department.

80. San Diego Police Department Personnel Division, 1994.

81. Donovan Jacobs. "Borderline, border crime, border cops!" The Informant. Vol. 13, issue 5. June 1993, 14-15 \& 17. The official publication of the San Diego Police Officer's Association.

82. Ibid., $1+15$.

83. Joseph Wambaugh. Lines and shadows. Bantam Books, New York. 1984, 263-283. Following this shooting, the Chief of Police from the Tijuana Municipal Police Department was very upset with San Diego Police for shooting two of his uniformed officers. His officers thought the aliens were border bandits and wanted to take them back to their country. The México Liaison officers, Manny Smith and Ron Collins, were questioned by the Méxican officials, because of the shooting. This shooting caused a number of problems for the liaison officers.

84. Ibid., 15.

85. Castanien, op. cit., 101.

86. The official publication of the San Diego Police Officer's Association. The Informant. Vol. 5, issue 9. December 1985.

87. James Gregory. US Magazine, December 31, 1984. One square mile of hell. 28-31. During the first year of BCPU operations, several bandits have been arrested for attempting to murder an officer. On one occasion, United States Border Patrol Agent James Bendorf was shot in the face when he came to the aide of his fellow officers. Bendorf reported that while in the hospital the doctors found a .38 caliber bullet in his jaw, a quarter of an inch from his carotid artery.

88. United States Border Patrol Chief patrol Agent Alan E. Eliason concurred with the intent of the operations manual and forwarded his approval, expressing confidence that the officers safety and successful operation would continue. This memorandum was sent to the supervisor assinged to the BCPU team, Stuart A. Kutz, dated February 28, 1985, SDC 1221/33.8-C.

89. Fallon, D. (1984). The National Centurion: A police lifestyle magazine. Volume II, number VII. Battle at the Border. August 1984. pp. 24, 36-37, 39, 54. 
90. Jacobs, "Borderline. ...," op. cit., 15.

91. John Morrison. The Informant. Vol. V, issue 10. November, 1985, 16-17. The official publication of the San Diego Police Officer's Association. These incidents were reported by then officer Cesar Solis as told to John Morrison of The Informant. Solis is now a San Diego police sergeant and Morrison retired as a police lieutenant from the San Diego Police Department.

92. Judicial is a common term used to identify the State Judicial Police Department in México. People simply refer to this law enforcement agency as "Judicial."

93. Morrison, "Informant. . .,"15. Sergeant Reggie Frank was one of the supervisors during this tour of duty. Each tour is four months with a four month break in between. As long as there are people from other countries trying to cross into the United States, for freedom, there will be a need for protectors of innocent lives.

94. Jacobs, op. cit., "Borderline. ..., "15 \& 17.

95. Ibid., 15.

96. A San Diego Police Department memorandum dated December 20, 1988 from Chief Bob Burgreen outlining the concerns of the Southern Division officers. Memorandum dated January 8, 1989, in response to Chief Burgreen's memo, from John Gregory, lieutenant to Acting Commander for Field Operations Zone II, Captain Richard Toneck.

97. A San Diego Police Department memorandum, dated January 10, 1989, from Captain Richard Toneck of Southern Division to Commander Dave Worden, Field Operations, it outlines the 35 shooting incidents that BCPU was involved from February 4, 1984 to January 4,1989. As a result of these shooting incidents, the BCPU was taken out of the hills and out of operations. The BCPU team was reactivated in May 1989.

98. The Informant. Vol. 7, issue 1. January 1987, 14-15. The official publication of the San Diego Police Officer's Association.

99. Ibid., 14. Carl Smith. The victims along the border are abundant, unarmed, passive, and illegal. This makes most of the victims easy targets for the border bandits. Smith went to the border to write an article for The Informant, but he got an education. The innocent victims had no protectors until the formation of the BCPU.

100. John Morrison. The Informant. Vol. 9, issue 3. March 1989, 2, 4, \&6. The official publication of the San Diego Police Officer's Association. John Morrison was the Managing Editor of The Informant.

101. James W. Nickel. "Human Rights and the rights of aliens," in Peter G. Brown \& Henry Shue, (eds.), 1983, The Border that joins: Méxican migrants and U. S. responsibility, (pp. 31-45). Roman and Littlefield, Totowa, New Jersey. 
102. The South Levee is an area approximately one and a half miles in length and a quarter mile wide. Areas along the South Levee are referred as W-3 through W-9. Other points of reference are the Waterfall, Steward's Bridge, and the Gravel Pit (South of Monument and Dairy Mart Roads). The distance between the South Levee and the U.S./México fence is 20-30 yards. Most reported crime occurred on the South Levee and the border fence. Memorandum dated April 24, 1990 from Lieutenant Dave Bejarano to Captain Phil Jarvis, both of Southern Division.

103. A San Diego Police memorandum dated December 1, 1989 from Sergeant Joe Wood to Captain Phil Jarvis, both from Southern Division. The report outlines statistical information and recommendations for the newly created Border Crime Intervention Unit. The members of the team made 36 felony arrests since June 23, 1989 to December 1, 1989. Each of these arrests had been connected to suspects involved in alien criminal activity. These arrests were accomplished in high risk situations and without the use of deadly force by members of the team. The team was comprised by five San Diego Police officers and a sergeant, no U.S. Border Patrol agents were on the team.

104. The statistical information from 1984 to 1986 were obatined from the San Diego Police Department Border Crime Prevention Unit (BCPU). The data for the same crimes were only available from back to 1982. The crimes are as follows: 1982 homicides were not avaiable; 1982 rapes were 4 ; and 1982 robbery were 36 . The number for 1983 were as follows: homicide data were not available; rapes were 6 ; and robberies were 41 .

These data were available from the SDPD's Crime Analysis Unit, on the fifth floor of the police headquarters building.

105. A San Diego Police Department memorandum dated December 19, 1990 from Sergeant Greg Sloan to Lieutenant Lee Vaughn, both of Southern Division. This memo outlines the history of BCIU. Sergeant Sloan was the team's supervisor.

106. See the report prepared from this hearing, available at the University of San Diego Learning Resource Center, KFC 698, A2. 1990b. First floor, southwest corner. California Legislature, Joint Committee on Refugee Resettlement, International Migration and Cooperative Development. Joint Hearing on International Migration and Border Region Violence. June 22, 1990, At San Ysidro California.

Other issues were: overview the general situation from governmental perspective from both México and San Diego County; context-current state of U. S. -México relations and socioeconomic dynamics of border region; and current or proposed mechanisms to address specific problems and underlying causes and how the state can effectively facilitate protection for migrants and reduce tensions in border region.

107. Gustavo del Castillo, Ph.D. Director of Department of U. S. Studies at El Colegio de la Frontera Norte, Tijuana, Baja California, México. Testimony 
presented before the California Joint Committee on Refugee Resettlement, International Migration and Cooperative Development. Senator Art Torres, Chairman. June 22, 1990.

108. Dr. Castillo suggested that Méxican labor, like any other commodity traded in the international markets be licensed by the Méxican government thus guaranteeing its quality. In addition, labor should be allowed to flow freely under certain conditions. these conditions are that labor flows be temporary and that they manifest themselves as individual workers in search of a job contract, or that a service company under contract hire workers for a specific job and duration. Thus the Méxican government certification of a company's credentials would be necessary.

Dr. Castillo suggested that Méxican labor flow to the United States would be composed of certified workers and of certified companies hiring Méxican workers. The certification process does not mean having a permit to immigrate, but only that an individual has the skills to perform the job. Immigration process would remain the same as the existing procedures.

109. Roberto Martinez testimony before the California Legislature Joint Committee on Refugee Resettlement, International Migration and Cooperative Development on International Migration and Border Regional Violence, San Diego June 22, 1990. Mr. Martinez represented the US/ México Border Program of the American Friends Service Committee, a human rights group. This Committee has a long history and tradition of humanitarian aid, justice and human rights in the United States. Martinez is concerned with the growing lack of respect for the rights and dignity of immigrants crossing into the United States.

110. Roberto Martinez has documented 23 incidents in which the USBP was invovled in either wounding (14) or killing (9) a person. He has also recorded the number of incidents involving the BCPU. The BCPU has been invovled in 13 incidents in which people were wounded (4) or killed (9). These figures are from July 1974 to December 1989.

111. Richard Neely, second in command at the San Diego County District Attorney's Office. In addition to the task force, Mr. Neely suggested that the victims and/or witnesses to border crimes could be gainfully employed on a temporary basis while awaiting their court appearances.

112. Chief Manny Guaderrama participated at the California Legislature Joint Committee on Refugee Resettlement, International Migration and Cooperative Development on June 22, 1990 at San Ysidro, California. The Joint interim Hearing on International Migration and Border Region Violence, KFC 6989, A2. 1990b. Chief Guaderrama was the only Hispanic ranking officer for the San Diego Police Department at the time.

113. Ibid., 2. The SWAT officers were removed from the BCIU team in 1991 and again in 1993. In 1994, the SWAT officers still remain out of the BCIU team and only provide training when needed. 


\section{Ibid.}

115. The City of San Diego obtained a special radio license on June 2, 1992 and it expires on June 2, 1997. The file number is 9203261028 . This radio communications allows for better communications between BCIU and the Beta Group.

116. A Memorandum dated February 29, 1992, submitted to San Diego Police Department Chief of Police Bob Burgreen from Javier Valenzuela, commander of the Beta Group, after obtaining permission from Edmundo Salas Garza, director of Inspection of the Secretary of the Interior, to give BCIU their Méxican radio frequency.

117. Ibid., members of BCIU arrested 14 robbery suspects who had fled north from Tijuana in order to avoid apprehension in México. The Méxican officers arrested 11 suspect that had fled south from San Diego. These suspects were responsible for five robberies in the United States. Memorandum dated December 19, 1990 from Sergeant Greg Sloan to Lieutenant Lee Vaughn, both of Southern Division.

118. Border Crime Intervention Unit Policy and Procedures Manual, up-dated January 6, 1994 by Adolfo Gonzales, Lieutenant. This manual also provided for policy on monthly management meeting between BCIU and Beta Group supervisors. In addition to providing four hours of training each month for members of the Beta Group. Other information contained in the policy manual is considered confidential and can not be release.

119. In 1986, the Border Crime Intervention Unit (BCIU) began operations but not necessarily in the hils. These data came from SDPD BCIU.

120. Murray Galinson was the Chairperson for the Blue Ribbon Committee. This information was taken from the final report submitted by Galinson to the City Manager, 1992, 2.

121. Ibid., 16-18.

122. Ibid., 16.

123. Ibid., 18-19.

124. San Diego Police Department Procedure 6.18 (Patrol) dated 01/15/94. This policy contains six pages, compared to the old policy which only had one page. The new policy includes topics such as: exceptions, situations where Border Patrol involvement is prohibited, migrant camps, documentation of detentions, assistance to other law enforcement agencies, and undocumented juveniles.

This searcher participated in the committee that revised this policy and also conducted the training sessions for the San Diego Police Department on its application.

125. The San Diego Police Department did not compiled undocumented person 
statistics until Chief Sanders made a commitment to serve the community and deal with the growing problem of undocumented persons committing crimes. The information was provided by the San Diego Police Department Crime Analysis Unit, January 31, 1995.

126. Carlos Rico. (1993). From State to "state": Managing México's California connection. In Lowenthal, A. F., \& Burgess, K. (Eds.). (1993). The California México connection. Stanford, CA: Stanford University Press. p. . The Beta Group established lines of communications with U.S. Border Patrol over a special radio frequency.

127. San Diego Union. December 11, 1991, E-1 and E-3. “On the law's edge: Crack Méxican police team wages war on border crime." The Executive Lieutenant for the San Diego Police Department at the Southern Division was Lee Vaughn, now a police captain working in the Northeastern Division.

128. Ibid., E-3. Javier Valenzuela, although new to law enforcement, understood the problems facing the migrants and officers. He said their mission was not to help or hinder thousands of illegal border crossings taking place day and night along the border, a sensitive subject in México.

129. Mario Arturo Coutino, 40, previously worked in agrarian reform and indigenous affairs in the southern border state of Chiapas, México.

130. Sebastian Rotella reporter for the L. A. Times. Rotella has been following the Beta Group's developments from the beginning in 1990. Los Angeles Times, September 15, 1993, Part A, Page 3, Column 2.

131. Ibid.

132. Ibid. The debate over the Beta Group's direction grew partly out of personality conflicts. The prior Beta commander, Valenzuela had developed strong loyalties and his successor had dismissed several of the Unit's founding members.

\section{Ibid.}

134. Sebastian Rotella, staff writer for the Los Angeles Times reported that Hugo Miguel Ayala Morales worked as a Méxican Immigration Service official and was replaced by at the end of President Salinas' term.

135. San Diego Union. February 14, 1995, B-1 \& B-4. Alejandro Olea is a retired Méxican cavalry officer, considered an expert in military intelligence. As a sublieutenant, in the 19 th, 8 th, and 23 rd cavalry regiments, Olea took part in operations against drug trafficking organizations in the states of Coahuila, Michoacan, and Sinaloa México. From 1978 to 1988, Olea was a member of the Estado Mayor Presidencial, an elite corps of plainclothes army officers charged with presidential protection, similar to the U.S. Secret Service.

136. Jacobs, op. cit., "Borderline. ..," 115 \& 17. 


\section{Ibid., 17.}

138. United States Department of Justice, Immigration and Naturalization Service, United States Border Patrol; Mission Statement. The task of the border guards was to stem the growing problem of illegal entries from México. Today, there are 4,000 Border Patrol agents nationwide dedicated to patrolling some 8,000 miles of international borders.

139. The USBP uses a variety of techniques to combat the growing problem of illegal entry. The agents maintain surveillance, follow-up on leads, respond to electronic sensors and aircraft sightings, and other tactics that are confidential.

140. The close proximity of Los Angeles and the ready accessibility of highways, commercial transportation and alien smuggling are all factors that make San Diego a popular illegal crossing area. San Diego Sector, US Border Patrol, Operational Profile.

141. Courtesy of the United States Border Patrol, San Diego Sector, 1994. There were no records for apprehensions for the fiscal years 1960-1963.

Every illegal alien detained by the INS has the right to a deportation hearing in which an immigration judge determines whether the alien has a right to be or remain in the United States. However, the alien may waive his/her right to a deportation hearing and request a voluntary departure to his country of origin. The US Border Patrol uses forms I-826, "Advisal of Rights" and the I827B, "Request for Disposition," when explaining to the alien his/her rights.

142. Western Region Media Briefing Guide, 04/05/90. United States Border Patrol, San diego Sector, 1994.

143. San Diego Union/Tribune, "High-power lights go up on 4-mile border stretch: Project augments steel fence to help seal especially porous area." January 22, 1994, B-1 \& B-2.

The US Border Patrol began experimenting with intense lighting system three years ago, when it placed stadium lights along the Tijuana/San Ysidro border at the Tijuana River levee.

144. Grace Napolitano, Chairperson, Assembly Member of the Assembly Select Committee on Statewide Immigration Impact. "Summary Report Assembly Select Committee on Statewide Immigration Impact." Prepared by Assembly Office of Research, Jimmy R. Lewis, Director, Co-authors, Jennifer Mu and Brent Bamhart, May 1994. State of California, Assembly Publications Office, State Capitol, Box 942849, Sacramento, Ca. 94249-0001.

145. Deportable aliens, in a context of "criminal alien," generally refers to undocumented persons who have committed crimes, or any non-citizen who is convicted of certain serious crimes specified by federal law, including aggravate felonies, drug offenses, etc. 
146. This amount included the costs of law enforcement, prosecution, probation, and incarceration, and the cost of the juvenile justice system.

147. Daniel Wolf, Center for U. S.-Méxican Studies at the University of California at San Diego. See his testimony at the "Immigrants, Immigration \& the California Economy: A compendium of materials submitted at an informational hearing of the Assembly Select Committee on California-México Affairs" (Assembly Publication No. 0473-A, Sacramento: February 25, 1993).

148. The U. S. Transfer Treaty Program originated with México under President Carter in 1976, and now includes U. S. treaties with about 40 nations. The Transfer requires a three-party consent, the U. S. government, the government of the prisoner's home country, and the prisoner. Given the process, very few criminal aliens have been transfer-red. In California, 18 of 150 requests were granted between 1983 and 1991, mainly national of México and Canada.

See Criminal Alien: A report of the California State Legislature Joint Committee on Prison Construction and Operations (Sacramento: March 1993).

149. San Diego Union, "Clamp down along border starts at dusk." October 1 , 1994. U.S. Attorney General Janet Reno unveiled Operation Gatekeeper during a recent visit to San Diego. The goal is to control the California border against illegal immigration.

150. United States Border Patrol, San Diego Sector, only the three main stations that apply to the 14-mile stretch of border are listed. The San Diego Sector of the Border Patrol covers nine stations; Imperial beach, Brown Field, Chula Vista, Campo, Boulevard, El Cajon, San Clemente, San Marcos, and Temecula. The data was collected from US Border Patrol, 1995.

151. Prior to the enactment of the first general immigration law of August 3 , 1882 , there was no federal agency charged with the supervision of immigration. The Act of 1882 vested responsibility to the Secretary of the Treasury (22 Stat. 214.).

152. All regions of legal immigration include; Europe, Asia, Africa, Oceania, North America, Caribbean, Central America, South America, and others.

United States Department of Justice, Immigration and Naturalization Service, official documentation on legal immigration admitted between 1989 to 1992 .

153. Ibid., this documented contained over twenty countries of birth for 1989 to 1992 legal immigrants. China (PRC) has had over 30,000 legal immigrants per year since 1989 to 1992 , there have recently been large numbers of illegal entries into México from China.

154. These figures showed that legal immigration has included many countries throughout the years. Data obtained from the United States Border Patrol, San Diego Border Patrol Sector, P.O. Box 439022, San Diego, Ca. 92143-9022, from the 
Public Information Officer.

155. The Immigration and Naturalization Service, U. S. Department of Justice, participated at the June 22, 1990 Hearings on Border violence at San Ysidro, California. A report from Washington was faxed to the Committee, but it was not signed. The report was sent on June 20,1990 at 1604 hours, to the Congressional Committee. This report can be found at the University of San Diego LRC, KFC 698 A2. 1990 b.

156. Gustavo de la Vina, Chief of San Diego Sector Border Patrol, testified before the Assembly Select Committee on Statewide Immigration Impact, May 1994.

Department of the Army and Air Force, Office of the Adjunct General, California National Guard, letter to Honorable Grace Napolitano, dated March 24,1994, from Tandy K. Bozeman, Major General, the Adjutant General.

157. The Immigration and Naturalization Service, U. S. Department of Justice, participated at the June 22, 1990 Hearings on Border violence at San Ysidro, California.

158. The United States Border Patrol has committed to assisting the local law enforcement agencies in preventing border violence and reducing senseless murders along the border region.

159. The United States Border Patrol's involvement in the border task forces ranged from active participation,with five agents and a supervisor, to the current policy of just a supervising agent working as a liaison between BCIU and the Beta Group. The U. S. Border Patrol supervisor was actively involve as a participant with $\mathrm{BCIU}$ and was used as an interpreter.

160. Castanien, op. cit., 83

161. Price, op. cit., 10-11. Minors under twenty one years of age and over eighteen years of age are permitted to consume alcoholic beverages in México. México was an attractive place for the young adults to visit.

162. San Diego Tribune, January 4, 1958.

163. Castanien, op. cit.

164. Ibid., 83

165. Ibid., 84.

166. Ibid.

167. San Diego Tribune. February 4, 1971. A-4. 
168. San Diego Union. July, 11, 1975, B-1. "Police to end border check."

169. Castanien, op. cit. 98.

170. Joseph Wambaugh. (1984) Lines and Shadows. Bantam Books, New York: New York.

171. Castanien, op. cit., 107.

172. The Méxican liaison team consists of two San Diego Police officers working in México as liaison to San Diego Police Department and to other United States law enforcement agencies. This team works outs of the Criminal Intelligence office.

173. Since 1889 to the present, 31 men have served as San Diego Chief of Police. Four men have also served as Acting Chief of Police.

174. San Diego Union, May 18, 1993, B4.

175. The Neighborhood Policing Restructuring Project consisted of 11 sworn and civilian personnel, lead by Captain Dave Bejarano from Southern Division. The steering committee had 14 assistants from throughout the department as technical support staff. The final report of the Neighbor-hood Policing Restructuring Project Committee was titled: Neighborhood Policing: The next generation.

176. San Ysidro Port of Entry is the busiest border crossing in the world. The second Port of Entry was opened in Otay Mesa to assist with the commercial crossing. This Prot of Entry is only open during business hours, primaryily from 0600 to 2200 hours daily.

177. A. F. Lowenthal, \& K. Burgess. (Eds.). (1993). The California México connection. Stanford, CA: Stanford University Press, 349.

178. San Diego Police Department Commemorative Album, 1889-1986. San Diego Police Officer's Association.

179. Ordinance $\# 6311$, section 6. Ordinance, City of San Diego, V. 20:20, can be found in the San Diego Historical Society Research Archives (SDHSRA). The Books of Ordinances are original; the entries are handwritten and listed in numerical order; and the volumes are handbound.

180. Although the matrons were sworn personnel, they did not receive guns or handcuffs, nor did they go out in the field.

181. Pliny Castanien, San Diego Police historian, said the Department routinely used policemen's wives to assist with female prisoners prior to the creation of the matron office. See San Diego Police Department 1889-1986, 36.

182. Civil Service Commission Minutes, 1919, 40. (CSC Minutes), City of San Diego Administration Offices, Sixth Floor, Downtown San Diego, Ca. 
183. Donovan Jacobs. "Borderline, border crime, border cops!" The

Informant. Vol. 13, issue 5. June 1993, 14-15 \& 17. The official publication of the San Diego Police Officer's Association. 


\section{CHAPTER III}

\section{METHODOLOGY}

Within this chapter the following areas were discussed:1) the research design; 2) the research questions; 3 ) the procedures used for data collection; and 4) the data analysis.

The process used in this dissertation was an historical case study investigation which was designated as documentary research. According to Mouldy, documentary research is based on documents and records. 1 Stake stated that case studies can be expected to continue to have epistemological advantage over other inquiry methods as a basis for naturalistic generalization. In other words, case studies will often be the preferred method of research because they may be epistemologically in harmony with the reader's experience and thus a natural basis for generalization. 2 Case study research has several purposes, such as, to chronicle events; to render, depict, or characterize; to instruct; and to try out, prove, or test. 3 Researchers expect an inquiry to be carried out so that certain 
audiences may benefit--not just to fill the archives, but to help persons toward further understanding of subject matter under investigation.

Research Design

The research project concerned itself with data collection and evaluation, as it related to the relationship between the San Diego Police Department and the San Ysidro/Tijuana border region and the role of the San Diego Police Department along the San Ysidro/Tijuana border between 1957-1994. This study utilized an historical case study design, involving the review of historical documents, newspaper articles, memoirs, photographs, and official police documents.

A case study need not be a person or enterprise. It can be bounded by whatever system is of interest. An institution, a program, a responsibility, a collection, or a population can be used as a case for study. Case studies can be used to test hypotheses, particularly to examine a single exception that shows the hypotheses to be false. In social studies literature, most case studies feature descriptions that are complex, holistic, and involving a myriad of not highly isolated variables; data that are likely to be gathered at least 
partly by personal observation; and a writing style that is informal, perhaps narrative. Themes and hypotheses may be important, but they remain subordinate to the understanding of the case. 4

The historical method of case study ascertains the truth by means of common sense. Common sense is more than what is usually found at work in daily life. It includes a systematic application of common sense, a closer attention to detail, and order. The exercise of these capacities turns into a new power; for the historian's common sense must be understood to mean more than common knowledge and the clichés of ordinary thought.

Methodical common sense takes in both what is usually known by the well educated and any special information relevant to the historical question being studied; and to these bodies of fact and ideas it brings the habit of comparing and judging with detached deliberation. 5

The evaluation of historical data, poses certain problems of reliability and validity. Historians, therefore distinguish between primary data and secondary data. Gottschalk defined a primary data source as, "The testimony of an eyewitness, or of a witness by any other of the senses, or of a mechanical device like dictaphone-that is, 
one who... was present at the events of which he tells. A primary source must thus have been produced by a contemporary of the events it narrates."6

Primary sources are tangible materials that provide a description of an historical event and were produced shortly after the event took place. Primary data takes many forms: newspaper accounts, letters, public documents, court decisions, eyewitness verbal accounts, and personal diaries. Secondary sources, borrow the knowledge they contain from other sources, the evidence contained in them being indirect or hearsay.7

\section{Research Questions}

It is the intent of this research to examine the relationship between the San Diego Police Department and the San Ysidro/Tijuana border region and the role of the San Diego Police Department along the San Ysidro/Tijuana border between 1957-1994. Based on the foregoing, the following questions were postulated:

- When and how was the United States/México international border established at the San Diego/Tijuana border region?

- What was the role of the San Diego Police Department at the international border from 1957 to 1994 ? 


\section{Procedures}

Once the researcher identified the topic for investigation, the researcher collected known "historical sources" of the period under investigation. In order to collect sufficient data, the researcher visited the San Diego Public Library, the Chula Vista Public Library, the University of San Diego Library, the University of California at San Diego Library, the San Diego Historical Society Archives, the International Boundary and Water Commission files, the City of San Diego Archives, the San Diego Police Department Crime Analysis Unit, the San Diego Police Officer's Association Archives, and the United States Border Patrol Archives.

The researcher first went to the University of San Diego library and conducted a computer search on the local computer system. This search revealed various books and newspaper articles of interest for this dissertation. The researcher also conducted a computer search of the other university computer systems, which lead to a couple of interesting Master theses from out of state universities. The person at the University of San Diego library's information desk requested the theses through an inter-library loan from other universities. Once these theses arrived at the University of San Diego, the 
researcher was notified to pick them up. The data provided additional references that the researcher was able to follow-up. The researcher then went to the Law Library at the University of San Diego. There, the researcher was able to collect legal documents, articles, and public hearing reports relating to immigration matters and border issues.

The researcher later went to the University of California at San Diego bookstore, the San Diego State University Library, the San Diego public libraries, the International Boundary and Water Commission files, the San Diego Police Officers Association Archives, the United States Border Patrol Archives, and other institutions and law enforcement agencies. The researcher validated the data by comparing various pieces of information with other known data or sources.

At each of the local libraries, computer searches were conducted which led to additional data sources. The researcher checked out books, reviewed microfiche newspaper articles, and bought books from the UCSD bookstore and the San Diego Police Officers Association Pride Store.

The researcher obtained, from the San Diego Police Officers 
Association, the San Diego Police Department Commemorative Album and Pliny Castanien's book, To protect and Serve, which made reference to the history of the San Diego Police Department and its chiefs of police. The researcher also obtained the Up Front (San Diego Police Department magazine) dating from 1985 to 1994 . The police magazines were made available to the researcher because of his membership in the San Diego Police Officer's Association. These materials contained information of interest and a number of references. The researcher followed-up on the references and located other sources with valuable data such as the San Diego Historical Society, various San Diego and Los Angeles newspapers. In addition to these resources, several informal interviews were held with retired San Diego Police officers and some active duty police officers in order to further substantiate the accuracy of the data.

After collecting significant names, dates, and events, the researcher went to the San Diego Historical Society Archives and found additional historical data related to the history of the City of San Diego, the San Diego Police Department and its chief of police. The San Diego Historical Society had a number of boxes which 
contained un-catalogued materials relating to the history of the San Diego Police Department. The researcher was allowed to search through these boxes because of his position with the San Diego Police Department. As the researcher searched through boxes of data, much of the data were filed under incorrect headings; for example, one of the boxes contained a photograph labeled "Border Alien Robbery Task Force" but the photograph was that of members of the Border Crime Prevention Unit. Many of the materials did not have dates or references of the period and therefore were not used in this dissertation.

The San Diego Historical Society (SDHS) also had data on the history of San Ysidro, Little Landers Colony, and the City of San Diego. Adjacent to the reference section of the SDHS Archives, was the photograph collection section. The researcher went to this section of the Archives and purchased several photographs of the San Diego Police Department, the San Ysidro/Tijuana border region, and the City of San Diego, which are included in this dissertation.

In 1979 and 1991, the researcher participated in a tour of duty at the border and recently visited the Southern Division of the San Diego Police Department. While at the Southern Division, the 
researcher collected data on the border enforcement teams. Some of the data, however, could not be used in this dissertation because it lacked authorship or dates. The data could not meet the external or internal criticism evaluation.

As with any fact gathering technique, one piece of information often leads to another then another and so on. The researcher kept following-up on leads and verifying pieces of the data by comparing one source with other sources. For example, data collected at the San Diego Historical Society from Herbert Hensley's memories were compared with data collected from newspaper articles of the period and a report complied by the City of San Diego.

Each lead that was developed, was compared with various sources for external and internal criticism. While at the Southern Division, the researcher found a City Manager's Report concerning the Border Crime Prevention Unit. The researcher went to the City of San Diego's Archives and obtained a copy of this report and other data related to the San Diego Police Department and San Ysidro community.

The researcher contacted the United States Border Patrol's México liaison agent and obtained historical and statistical data. The 
México liaison agent also collected data from the Méxican border team, the Beta Group.

\section{Data Gathering Techniques}

According to Glesne and Peshkin the use of multiple-datacollection methods contributes to the trustworthiness of the data. Data will be collected through naturalistic methods including observation, interviews, and document collection. This practice is known as "triangulation." 8

When collecting data, it is imperative for the researcher to follow the rule of "Give evidence." No matter how possible or plausible the researcher's conjecture about his/her case, it cannot be accepted as truth if he/she has only his/her hunch to support it. When a hypothesis is deliberately offered as such, it is an error to think it proved when it appeared consistent with the facts gathered. Proof demands decisive evidence, which means evidence that confirms one view and excludes its rivals. Consistency is not enough. Neither is plausibility, for both can apply to a wide variety of hypotheses. 9

Evidence that is decisive means that the truth rests not on possibility nor on plausibility but on probability. Probability is the 
balance of chances that, given such and such evidence, the event it records happened in a certain way; or, in other cases, that a supposed event did not in fact take place. 10

Historical research is based on existing data. Information that is collected is traced to a source and those who are knowledgeable about the event or situation. Those individuals are then used as informants and also as sources of written data.11

The researcher visited the previously mentioned facilities and institutions and collected primary sources of data such as written records including memoirs, public documents, police records and reports, newspaper articles, minutes of Civil Service meetings, microfiche documents, and photographs. As secondary sources of data, many books and articles were reviewed. A copy of the Treaty of Guadalupe Hidalgo, as well as historical documents were reviewed at the San Diego Historical Society Archives, in Balboa Park. After reviewing the forementioned data, the researcher located individuals who had first hand knowledge of events or situations related to this investigation. These individuals confirmed some of the information that was collected from written documents relating to the San Diego Police Department.12 


\section{Data Analysis}

An important issue in the analysis of historical data is to realize that data in historical research were not developed for use in research. Much of the data is distorted, biased, or otherwise invalid. The researcher must evaluate the data, a process referred to as historical criticism. Historical criticism includes external criticism, which is the establishment of the authenticity of the source including its date, author and legitimacy. Internal criticism evaluates the accuracy and worth of the statements contained in historical documents. 13

Historical analysis is particularly useful in obtaining knowledge of previously unexamined areas and in re-examining questions for which answers are not definite as desired. There are also weaknesses in the classification of historical data. Documents may be falsified deliberately or may be subjected to incorrect interpretation by the recorder. The researcher must decide what is and what is not fact.14

The main role of the historian is the interpretation of the data in light of the historical criticism. Each fact and supposition must be weighed and added to the historical case leading to the research 
conclusion. 15 The collection of facts must be arranged into some order and given some interpretation. The researcher must exercise judgement in deciding what is "relevant" evidence, and then in choosing how to present the evidence in a narrative form. 16 After collecting the data, the researcher verified its authenticity and reliability by comparing one source with other sources. Most of the data analysis was conducted by comparison of historical documentation, photographs, maps, and other sources with known data sources and telephone and personal interviews with law enforcement officers.

The data collected concerning the history of the city of San Diego, the Little Landers Colony, and the San Diego Police Department were supportive and verified by several sources; such as, newspaper accounts of the events, memories, and official government documents. The role and relationship of the San Diego Police Department and the San Ysidro/Tijuana international border between 1957 to 1994 , was documented in various official police reports and memorandums. Based on primary document sources, the role and relationship of the San Diego Police Department's border task force teams showed marked improvement, in reducing border 
violence, when there was collaboration with the Mexican law enforcement task force known as the Beta Group.

\section{$\underline{\text { Limitations }}$}

The stated purpose of this study was the examination of the role and policy of the San Diego Police Department along the San Ysidro/Tijuana international border between 1957 to 1994 . This historical case study was conducted with special attention given to the role of the Border Crime Intervention Unit and the Beta Group because of their unique partnership and collaboration. The special reiationships between officers from México and the San Diego Police Department were evident in their law enforcement strategies along the border.

This study was limited to the San Diego Police Department's role and policy along the international border, and the Department's relationship between the Beta Group (México's law enforcement team) and the Border Crime Intervention Unit between 1957-1994. A niajor limitation of historical research is that there is limited opportunity to test the conclusions in a new situation. It may be possible to validate a general conclusion, but much of it is specific to the situation researched, and unless new data are discovered it may 
not be profitably researched again. 17

Another limitation is that the data are always incomplete. The researcher must draw his/her conclusions from partial or fragmentary evidence. Yet another limitation is that the data were not created for research, they had another purpose and risk being biased. When there are divergent sources of data converging on a similar conclusion, however, the limitation is reduced.18 


\section{CHAPTER III}

\section{METHODOLOGY}

\section{ENDNOTES}

1. George Mouidy, Educational Research. Boston: Allyn and Bacon, Inc., 1970., p. 171.

2. Robert E. Stake, The case study method in social inquiry. In evaluation models: View points on educational and human services evaluation. George F. Madaus, Michael S. Scriven, and Daniel L. Stufflebeam. 1983. Norwell, MA.: Kluwer-Nijhoff.

3. E. G. Guba \& Y. lincoln. (1981). Effective evaluation. San Francisco: JosseyBass.

4. Louis Smith. An aesthetic education workshop for administrators: Some implications for a theory of case studies. Paper presented at AERA, Chicago, 1974.

5. Jacques Barzun \& Henry F. Graff. The modern researcher. (5th. ed.). New York, NY.: Houghton Mifflin Company. 1992, 154-201.

6. Louis Gottschalk. (1950). Understanding history: A primer of historical method. New York: Knopf.

7. John B. Williamson, David A. Karp, John R. Dalphin, and Paul S. Gray. (1982). The research craft: An introduction to social research methods. Second Edition. Boston, Ma.: Little, Brown, \& Company. 239-259.

8. Corrine Glesne \& Alan Peshkin. (1992). Becoming qualitative researchers: An introduction. White Plain, NY.: Longman Publishing.

9. Barzun \& Graff., op. cit., 166.

10. Ibid., 166-167.

11. Gary Anderson. (1990). Fundamentals of Educational Research. New York: The Falmer Press.

12. Retired San Diego Police officers Ron Collins, Dave Crow, Paul Ybarrando, and Officer Laura McGawn-Minto verified some of data collected and photographs.

13. Gottschalk, op. cit. 
14. Catherine Marshall \& Gretchen B. Rossman. (1989). Designing Qualitative Research. Newbury Park, CA.: Sage.

15. Anderson, op., cit.

16. Sharan B. Merrian \& Edwin L. Simpson. (1984). A guide to Research for Educators and Trainers of Adults. Malabar, FL.: Robert E. Krieger Publishing Company.

17. Anderson, op., cit.

18. Ibid. 
CHAPTER IV

SUMMARY OF THE ROLE AND RESPONSIBILITY OF THE SAN DIEGO

POLICE DEPARTMENT ALONG THE SAN YSIDRO/TIJUANA BORDER REGION, 1957-1994.

Based on the review of the literature and the collection of documents, records, and criminal statistical information, the role of the San Diego Police Department at the border suggested a strong relationship with the United States Border Patrol from the 1970s to the present and with Méxican law enforcement agencies during the 1990s. In the late 1970s, however, the San Diego Police Department did not have such a relationship with México's law enforcement agencies.

\section{International Border}

In 1848 , the Méxican-American War came to an end with the signing of the Treaty of Guadalupe Hidalgo. The terms of the Treaty resulted in México giving up more than one-half of its Republic. México was to receive $\$ 50$ million dollars and have its debt of two 
million dollars canceled by the United States. Furthermore, the Méxican population remaining in the new region were given United States citizenship. In Old Town San Diego, many Méxican families remained, now governed under the laws set down by the United States Government. Those citizens who desired to return to México could have done so; those who remained had to become U.S. citizens. Méxican citizens who had been living on properties they once own, were now required to offer proof of ownership in American courts. The final draft of the Treaty read, in part:

And, in order to preclude all difficulty in tracing upon the ground the limit separating Upper from Lower California, it is agreed that said limit shall consist of a straight line drawn from the middle of the Rio Gila, where it unites with the Colorado, to a point on the coast of the Pacific Ocean distant one marine league due south of the southernmost point of the port of San Diego, according to the plan of said port made in the year 1782 by Don Juan Pantoja, second sailing master of the Spanish fleet, and published at Madrid in the year 1802...1

Following the signing of the Treaty of Guadalupe Hidalgo, negotiations over the location of the United States-México border ranged from conceding California as a part of México to giving Baja California to the United States. México said that Baja California was poor in natural resources and of no importance to the United States. 
México contended that Baja California was needed for the strategic defense of its Republic, and that México also needed a land communication route between Baja California and the Méxican mainland. The resulting line cut diagonally across the Tijuana River Valley, leaving the mouth of the valley on the United States side and the narrowing upper part of the valley on the Méxican side of the border. Thus, the San Diego-Tijuana international border was established.2

The City of San Diego was incorporated in March 1850, and had its first "American" election on June 16, 1850.

In 1957, the City of San Diego annexed the community of San Ysidro including: Palm City, Nestor, and Otay Mesa. This annexation brought San Diego's City limits to the international border. Although San Ysidro is politically part of San Diego, San Ysidro is separated from San Diego by the municipalities of Chula Vista and National City. Downtown San Diego is approximately 16 miles north from the San Ysidro-Tijuana Port of Entry. 3

Few people would disagree that immigration has profound implications on the social, political, and economic systems of the United States. Annually an average of 6,000 legal immigrants are 
accepted for permanent status in the United States. 4

The number of illegal aliens documented by the Immigration and Naturalization Service (INS) nation-wide for fiscal years 1990 was $1,103,353$ and 1991 was $1,132,933$. The United States Border Patrol reported 473,323 apprehensions in the San Diego sector for fiscal year 1990 and 540,347 for fiscal year 1991.5 Lamm and Imhoff estimated the one and a half million persons cross illegally near the international border on an annual basis. 6

The United States Border Patrol, INS, United States Customs Service, and other federal agencies have primary responsibility for enforcement of immigration laws along the border. Local law enforcement agencies and municipalities, however, interact with undocumented aliens on a daily basis and must deal with the immigration issue as well. The California Attorney General stated that there was no affirmative legal duty for local police officers to arrest undocumented persons who have entered this country unlawfully.7

San Diego Police Department (1863-1975)

In 1863, Sheriff James McCoy was given the formal title of "Chief of Police," so that he could better protect the people from 
exposure to smallpox disease. 8 The Sheriff was also directed to prevent any person residing in infected areas from entering the city, and, if anyone were caught in town, to promptly eject them. Sheriff McCoy was ordered to command all undesirable Indians and Méxicans, who were not employed, to leave town within 12 hours. 9

The City of San Diego was incorporated in 1888 and established its police department on May 16, 1889.10 Joseph Coyne (1889-1891) was the first Chief of Police. Prior to being appointed as Chief of Police, Joseph Coyne served as the Sheriff of San Diego County from 1876 to 1882.11

Adam Elmer Jansen was Chief of Police from October 16, 1947 to January 7,1962 . Chief Jansen accomplished a number of goals for the Police Department; in 1949, the police school became an Academy; in 1950, Chief Jansen created the San Diego Police Reserve program; on July 1,1954 , he appointed four policewomen, the first since the mid-1920s; he established a border substation at San Ysidro; and a police check point at the San Ysidro/Tijuana border. In addition, Chief Jansen improved liaison with Tijuana law enforcement agencies by assigning an officer to work south of the border and serve as a liaison between the San Diego Police 
Department and Méxican law enforcement agencies.12

The México Liaison officer worked out of the San Diego Police Department's Headquarters building. The liaison officer would assist the Méxican law enforcement agencies with criminal investigations concerning United States victims or suspects. 13

During 1952 and 1953, the San Diego District Attorney, Donald Keller, and others, launched a program designed to restrict entry of unchaperoned individuals under the age of eighteen years of age into México. This program served to screen juveniles going into Tijuana, Baja California, México, and turn back those juveniles who were unescorted by a parent or an adult.14

The San Diego Police Department established the Southern Division in 1957, when the City of San Diego annexed twenty-two square miles along the international border, creating South San Diego.15 Late in 1962, a new substation was built in San Ysidro for the Southern Division personnel at 663 Tijuana Boulevard, near the international border. On July 17, 1975, the San Diego Police Department closed the juvenile check point it had operated since 1957.16 
San Diego Police Department (1975-1988)

On February 13, 1976, Chief of Police, Bill Kolender, established a border task force headed by lieutenant Dick Snider. The purpose of this task force was to provide police service along the United States and México border within the City limits. 17

The Border Alien Robbery Task Force (BARF) as the task force was known, was created in 1976 but was abolished two years later. During the tenure of the BARF Unit, members were involved in seven officer involved-shootings which resulted in the wounding of three BARF members and the wounding of seven Méxican nationals. 18

The Border Alien Robbery Task Force was established in order to patrol the undeveloped canyons just north of the San Ysidro/ Tijuana border. These canyons and rural areas were used as the primary routes for illegal alien and narcotics smuggling into the United States. Border bandits from both sides of the fence preyed on the aliens as they struggled northward to the land of prosperity and jobs. Murder, rape, robbery, and assault on these mostly docile people forced the San Diego Police Department to make a bold move into the international law enforcement scene.19

Members of the BARF team were mostly Spanish speaking 
officers and were disguised as Méxican migrants, crossing illegally into the United States. The goal of the BARF team was to blend into the alien population as they moved north from the border to the canyons and apprehend border bandits. These officers patrolled the hills and canyons along the border on a nightly basis. Once the border bandits moved to assault or rob the disguised officers, the BARF officers would make the arrest. This initial encounter often resulted in gunfire between the bandits and BARF officers. After many high-profile and deadly shootings, the San Diego Police administration felt the border region was too deadly for both officers and bandits alike. In 1978, the BARF task force was suspended because of this extreme border violence. 20

A lack of law enforcement at the brrder region became apparent as the bodies and victims of border violence began to escalate after the removal of the BARF team.2i In January 1984, a similar task force as BARF was established by the San Diego Police Department and the United States Border Patrol. This team was called the Border Crime Prevention Unit (BCPU) and operated under a different philosophy than the BARF team. Members of BCPU actively worked with U. S. Border Patrol Agents as team members. 22 
Unlike the BARF team, members of the BCPU team were dressed in full uniform and their tactics consisted of low-key operations. 23 One of the original members of the Border Crime Prevention Unit, San Diego Police Officer Felix Aguirre, 28 years of age, was quoted by the US magazine regarding the uniforms as, "we were dressed in our street uniforms with our batons dangling from our belts. Every time we would try to sit, the batons would bang around and make all kinds of noise. When we tried to chase people, the batons were flying all over the place. After that, we didn't take them with us." 24

Members of BCPU participated in approximately 120 hours of classroom instruction and field training prior to being assigned to duties in the hills and canyons. 25

The combined task force disrupted the bandits' lucrative business and compiled impressive statistics. In contrast to BARF, the officers of the BCPU team took a high visibility profile by walking and patrolling the region in uniform and prominently displaying their badges.26 The San Diego Police administration hoped that this higher profile would reduce the number of armed confrontations between bandits and police officers. 27 
By 1986, the San Diego Police Department had changed it's philosophy and enforcement strategy along the border.

The following crime statistics for the Border Crime Prevention Unit (BCPU) demonstrated the violent nature of the border region:

Total number of selected violent crimes along the San Ysidro/Tijuana border region, 1984-1988.

$\begin{array}{lcccc}\text { Year } & \text { Murder } & \text { Rape } & \text { Robbery } & \text { Totals } \\ 1984 & 11 & 19 & 272 & 302 \\ 1985 & 12 & 25 & 312 & 349 \\ 1986 & 5 & 13 & 157 & 175 \\ 1987 & 4 & 9 & 84 & 97 \\ 1988 & \underline{11} & \underline{8} & \underline{43} & \underline{62} \\ \text { Total } & 43 & 74 & 868 & 985\end{array}$

Source: San Diego Police Border Crime Prevention Unit.28

After BCPU was removed from the hills, the administration of the San Diego Police Department wanted to prevent border violence, but they were concerned with the number of officer involved shootings. Thus the Border Crime Intervention Unit was established. San Diego Police Department (1988-1994)

By $1989, \mathrm{BCPU}$ transformed into the Border Crime Intervention 
Unit (BCIU). This team consisted of six San Diego Police officers and a United States Border Patrol supervisor, who worked as a liaison between San Diego Police and United States Border Patrol. This team also worked in full uniform and patrolled the same border area as the two previous task forces. Unlike the two previous teams, however, BCIU worked closely with the Méxican officials, the Beta Group. The cooperative efforts between these two teams of law enforcement agencies was an unprecedented law enforcement strategy for patrolling the San Diego/Tijuana border region.

The crime statistics collected from the San Diego Police Department Crime Analysis Unit showed the crime and arrest data from 1982 through 1994. The apprehensions made by the United States Border Patrol San Diego Sector increased following Operation Gatekeeper. Overall, these data reflected a decreased in reported crimes by undocumented persons. There was an increase of apprehensions by the United States Border Patrol along the area east of the Port of Entry after the introduction of Operation Gatekeeper. In addition, crime statistics from Méxican law enforcement officials were collected. The data from the Beta Group showed an increase of detentions and arrests of delinquents in México. 
Officials from the BCIU team and the Beta Group worked joint operations, trained together, and improved their communications. This collaboration resulted in a decrease of violence along the international border between the San Ysidro/Tijuana border region, and a reduction of officer-involved shootings by the San Diego Police Department. The new border task force (BCIU), and the cooperation and collaboration of the Beta Group, helped to improve the relationship between the United States and México law enforcement community and the community at large. The ability to work collectively between two different countries, cultures, and legal systems, in problem solving, required that each officer tactfully deal with these and other differences in a professional manner. Officers from both law enforcement agencies, BCIU and the Beta Group, were able to meet these challenges and work joint operations along the international border for a common purpose--preventing violence.

A look at the type and scope of border violence investigated by the San Diego Police Department shows a violent border. The crime statistics for the criminal activity investigated by the Border Crime Intervention Unit for the periods of 1989 to 1994 are as follows:

Total number of selected violent crimes along the San 
Ysidro/Tijuana border region, 1989-1994.

$\begin{array}{lcccc}\text { Year } & \underline{\text { Murder }} & \underline{\text { Rape }} & \underline{\text { Robbery }} & \text { Totals } \\ 1989 & 9 & 2 & 52 & 63 \\ 1990 & 8 & 4 & 102 & 114 \\ 1991 & 1 & 3 & 114 & 118 \\ 1992 & 0 & 4 & 72 & 76 \\ 1993 & 0 & 3 & 25 & 28 \\ 1994 & 1 & 6 & 14 & 21 \\ \text { Total } & 19 & 22 & 379 & 420\end{array}$

Source: San Diego Police Department BCIU.29

Border crimes for 1984 to 1988 showed 985 total violent crimes along the San Ysidro/Tijuana border region. A comparison with 1989 to 1994 , the first five years (1984-1988) of the border team's operations, indicated a high number of crimes as well as a high number of officer-involved shootings during this period. The high number of crimes and officer-involved shooting, however, decreased in the late 1980 s and early 1990 s.

Herman Goldstein (1990) stated that a new leadership style would be important to the success of problem-oriented policing. He suggested three changes: (1) Police leaders must articulate the basic 
values with which they approach the police task and which influence their management techniques; (2) they must have a strong commitment to problem solving as the core of policing; and (3) they must make fundamental changes in the most common type of relationship that exists between leadership and the rank-in-file of an organization. 30

Summary of the role and policy of the San Diego Police Department along the international border from 1957 to 1990.

It has been estimated that an average of 3,000 people try to cross illegally into the United States on a daily basis. The vast majority of these people carry their worldly possessions as they journey north. This in itself makes these people easy targets for border bandits. The bandits use "pre-demand" tactics to attack their victims. The border bandits would beat, stab, and shoot their innocent victims in order to gain compliance from the other members of the group.

Between 1957 to 1976, the San Diego Police Department did not have a formalized enforcement strategy with México law enforcement agencies for preventing border violence.

During the 1980's, the San Diego Police Department's Southern 
Division experienced an increase of border violence. In fact, some Méxican Law Enforcement Officials were suspected of committing crimes along the International Border. When the Border Crime Task Force was in existence, they were disguised as illegal aliens and were involved in armed confrontations with the Méxican police officers, who had crossed into the United States to commit their crimes. Between 1978 to 1984 , the San Diego Police Department did not field a team of officers along the border region. Police officers, however, did respond to calls-for-service as requested by those in need. In 1984, the administration of the San Diego Police Department decided to re-introduce a border enforcement team along the border. This team was called the Border Crime Prevention Unit (BCPU). This new team was assigned to work in full uniform. These officers worked as team members with five agents from the United States Border Patrol. The collaboration with México's law enforcement agencies, however, was limited. The only communication that San Diego Police Officers had with their Méxican counterparts was a special telephone that was connected directly to the Tijuana Municipal Police Department. This phone came to be known as the "Red Phone." There was little communication or cooperation between San Diego Police Officers and 
the Méxican Law Enforcement Officials. San Diego Police officers would communicate, with Tijuana Municipal Police Department, over this special telephone as needed. This communications technique required that the San Diego Police officer be a Spanish speaking officer in order to make the phone call and relay the necessary information. This method of communication with Méxican officials was one strategy in an effort to form a collaboration between law enforcement officers from two countries.

In May 1989, BCPU focused their operations on a five square mile area along the U.S./México International Border - West of the Port of Entry. At that time, due to the illegal immigration trend and the U.S. Border Patrol's up-dated tactics, most of the illegal crossing was funneled through an area known as the "South Levee." 31 During that time, the Border Crime Intervention Unit (BCIU) was performing fine, except for one major obstacle - the close proximity of the U.S./México International Border. When suspects would commit crimes in the United States, they would simply run back into México, across the fence (in some areas there were no fences) and escape apprehension. By the time BCIU would notify the Tijuana Municipal Police or the State Judicial Police, the suspects 
would be long gone. Moreover, when the same suspects would commit crimes in México, they would flee into the United States and avoid apprehension from the Méxican authorities. 32

Between December 1989 and March 1990, the Border Crime Intervention Unit suspended its operations in the hills and canyon areas, and did not conduct any tactical or surveillance operations.

It is common knowledge among law enforcement officials that the vast majority of crimes committed against undocumented illegal migrants, along the SanYsidro/Tijuana International Border, go unreported. The major reasons that illegal undocumented migrants do not report their crimes are: (a) the undocumented persons do not want to be apprehended by the United States Border Patrol and returned to their place of origin and (b) many undocumented persons fear the law enforcement agencies. The only time that these individuals will report a crime is when they are actually apprehended by U. S. Border Patrol or when they require medical treatment as a result of their attack. Most of the reported crimes, during this period, occurred along the area commonly known as the "South Levee".33

The "South Levee" is an area which is approximately one and a 
half miles long and a quarter mile wide. The areas along the South Levee are referred as W-3 through W-9. Other areas of interest are the "Water Fall", "Stewart's Bridge", and "Gravel Pit." The distance between the "South Levee" and the US / México Border is about 30 yards. Most of the reported crimes were occurring along the "South Levee" and border fence.

Summary of the role and policy of the San Diego Police Department along the international border from 1990 to 1994.

On March 17, 1990, the San Diego Police Department allowed $\mathrm{BCIU}$ to resume tactical operations along the U. S./México International Border. In this situation, a United States Border Patrol Supervising agent was assigned to the unit as a liaison between BCIU and the Border Patrol. The Border Patrol (BP) supervisor would communicate with field Border Patrol agents and alert them of BCIU's presence in the area.

The U.S. Border Patrol supervisor would share intelligence information with the BCIU officers. Although this addition was a welcome relief, the BCIU Team still had the problem of bandit suspects fleeing into México.

In addition, the collaboration with México's law enforcement 
agency (the Beta Group) had improved tremendously. Both, BCIU and the Beta Group, worked in partnerships and trained together tactically on suppression efforts. The communications between México (Beta Group) and the United States (BCIU) law enforcement agencies also improved with the addition of the special radio frequency authorized by the FCC. Members of BCIU and Beta Group communicated over this special radio frequency and deployed tactically in the region-along the border, to combat border violence.

According to a study conducted by the San Diego Association of Governments (SANDAG,1986), seven out of the ten local agencies in San Diego County had written policies for handling undocumented individuals.

In San Diego, if an undocumented person was involved in criminal activity, that person would be processed just like anyone else. But if the person was not involved in criminal activity, the person would not be contacted or would be released outright. Officers need probable cause, for the initial contact, before they can make a legal arrest.

A small number of the undocumented persons come to the United States to commit crimes. The study conducted by SANDAG 
(1986) showed that undocumented persons accounted for $12 \%$ of the felony arrests in San Diego. ${ }^{34}$ In addition, this group accounted for $19 \%$ of burglary arrests, and $20 \%$ of auto theft arrests. As a side note, the San Diego Sheriff's Department (SDSD) reported releasing 94 undocumented aliens who were charged with violent crimes from July 1991 to December 1991 (SANDAG and SDSD, 1991).

Most of the undocumented persons who enter the United States, come to find work. Many of these undocumented persons, who enter this country illegally seeking work, find themselves victims of the predatory bandits who operate in the rural areas along the San Ysidro/Tijuana International Border.

As a result of joint operations between BCIU and the Beta Group, numerous border bandits have been taken into custody. Prior to the creation of BCIU and Beta Group, many suspects would have fled into México or into the United States, depending where they had committed their crimes, and escape apprehension. But, today this is not the case. Many suspects are being arrested and prosecuted in México for crimes that they have committed in the United States. Under Méxican laws, a Méxican citizen can be prosecuted in México if he/she commits a crime against another Méxican citizen in a foreign 
country. A formal complaint and a thorough investigation are presented to the Méxican authorities for prosecution in México.

In addition to the improved communications, the supervisors from both units met monthly to discuss future training needs, communications issues, and to critique past joint operations.

In 1991, members of the Beta Group made 3,095 apprehensions along the international border on the Méxican side of the fence. They found that $10 \%$ of the suspects arrested for various charges were under the influence of drugs and/or alcohol at the time of their arrest; a total of $17 \%$ of the arrests made were for suspects being under the influence of drugs; and $5 \%$ of the arrests made were for suspects wanted in connection with assault cases--in which weapons were involved. In addition, the Beta Group's crime picture for 1990 to 1994 was as follows:

\begin{tabular}{|c|c|c|c|c|}
\hline Year & Murder & Rape & Robbery & Totals \\
\hline 1990 & 1 & 2 & 17 & 20 \\
\hline 1991 & 0 & 0 & 4 & 4 \\
\hline 1992 & 0 & 0 & 32 & 32 \\
\hline 1993 & 0 & 0 & 4 & 4 \\
\hline 1994 & 0 & 1 & 52 & 53 \\
\hline
\end{tabular}
Source: Méxican law enforcement, Beta Group, 1995. 
Maintaining a Bilateral International relationship with México's Beta Group was not easy. Historically, law enforcement officials from México have been known to have the "long arm of the law". They have been accused of bribery, extortion, and of border violence.

The Beta Group was like no other Méxican law enforcement agency. The Beta Group, by the nature of its structure (task force) was breaking the image of the "long arm of the law." The Beta Group was heading in the right direction toward professionalism, anticorruption, and justice. Supervisors and officers from both units, BCIU and Beta Group, met constantly and discussed crime trends, community concerns, communications issues, and future training needs. As a result of these meetings, both units worked several joint operations, arresting many suspects on both sides of the border.

This researcher strongly believes that the daily contacts and monthly meetings that were held with the Beta's command staff enabled BCIU to develop the excellent Bilateral International relationship it shares with México. The meetings between both units, were more than just meetings, the officers developed friendships and put those friendships to work in an effort to combat border violence. The officers became partners in a new era of crime fighting. 
They established a partnership which is unique and has not been duplicated in any other part of the country. Both Units are using resources from México and from the United States to deal with a common problem--border violence.

Conclusion

The hope for freedom, takes a larger number of undocumented migrants North, from México into the United States. These people first cross through the small community of San Ysidro, in San Diego. When these individuals manage to cross the U.S./México International Border, their hope for freedom is often interrupted when they find themselves victims of violent border crimes.

The San Diego Police Department's Border Crime Intervention Unit (BCIU) and Méxican Law Enforcement's the Beta Group,were working in a partnership in an effort to provide police service on both sides of the international Border. The partnership between BCIU and Beta Group made a tremendous impact on the reduction of violent crimes along both sides of the San Ysidro/ Tijuana border. 


\title{
CHAPTER IV
}

\section{SUMMARY OF THE ROLE AND RESPONSIBILITY OF THE SAN DIEGO \\ POLICE DEPARTMENT ALONG THE SAN YSIDRO/TIJUANA BORDER}

\author{
REGION, 1957-1994
}

\section{ENDNOTES}

1. Treaty of Guadalupe Hidalgo, Article V, as found in Peter Thomas Conmy, $A$ Centennial Evaluation of the Treaty of Guadalupe Hidalgo, 1848-1948. Oakland: Public Library, 1948, p. 28.

2. John A. Price, October 1968. A history of Tijuana: Border town and port of trade. San Diego State University.

3. Kenneth C. Martis. (1970). "United States International land border crossings: San Ysidro, California." A Thesis for Master of Arts in Geography, for San Diego State College, 20.

4. R. Lamm, \& G. Imhoff. (1985). The immigration time bomb-the fragmenting of America. E. P. Dutton: New York.

5. United States Border Patrol data for fiscal years 1990 and 1991. Information obtained from San Diego Sector USBP.

6. Lamm and Imhoff, op. cit.

7. SANDAG Report. (1988). The impact of illegal immigration on the criminal justice system. San Diego Association of Governments publication, July, 1989. SANDAG is comprised of members from most every city in the county.

8. San Diego Tribune, October 4, 1839.

9. San Diego Tribune, October 4, 1839. The only Indian exempt from leaving town within the 12 hours was Alcals José Manuel and his family.

10. MacPhail, Elizabeth C. (1969). The story of New San Diego and of its founder Alonzo E. Horton. 97.

11. Castanien, Pliny. ((1993). To protect and serve: 1889-1989. San Diego

Historical Society: San Diego, Ca. 4-8.

12. Ibid., 79-80. 
13. Personal interview with Ron Collins. Ron provided the names of those past México liaison officers. June 2, 1995.

14. Price, op. cit., 10-11.

15. The San Diego Union, "Police division in South Bay makes record 527 arrests." February 10, 1958, A-14.

16. San Diego Union. July, 11, 1975, B-1. "Police to end border check."

17. Ibid., 98.

18. Joseph Wambaugh. (1984) Lines and Shadows.

19. Donovan Jacobs. "Borderline, border crime, border cops!" The Informant. Vol. 13, issue 5. June 1993, 14-15\&17. The official publication of the San Diego Police Officers Association.

20. Ibid., 14-15.

21. Ibid., 15.

22. Castanien, op. cit., 101.

23. The official publication of the San Diego Police Officers Association. The Informant. Vol. 5, issue 9. December 1985.

24. James Gregory. US Magazine, December 31, 1984. One square mile of hell. 28-31. During the first year of BCPU operations, several bandits have been arrested for attempting to murder an officer. On one occasion, United States Border Patrol Agent James Bendorf was shot in the face when he came to the aide of his fellow officers. Bendorf reported that while in the hospital the doctors found a .38 caliber bullet in his jaw, a quarter of an inch from his carotid artery.

25. United States Border Patrol Chief patrol Agent Alan E. Eliason concurred with the intent of the operations manual and forwarded his approval, expressing confidence that the officers safety and successful operation would continue. This memorandum was sent to the supervisor assigned to the BCPU team, Stuart A. Kutz, dated February 28, 1985, SDC 1221/33.8-C.

26. Fallon, D. (1984). The National Centurion: A police lifestyle magazine. Volume II, number VII. Battle at the Border. August 1984. pp. 24, 36-37, 39, 54.

27. Jacobs, "Borderline. ..," op. cit., 15.

28. The statistical information from 1984 to 1986 were obtained from the San Diego Police Department Border Crime Prevention Unit (BCPU). The data for the same crimes were only available from back to 1982 . The crimes are as follows: 1982 homicides were not available; 1982 rapes were 4; and 1982 
robbery were 36 . The number for 1983 were as follows: homicide data were not available; rapes were 6; and robberies were 41 .

These data were available from the SDPD's Crime Analysis Unit, on the fifth floor of the police headquarters building.

29. In 1986, the Border Crime Intervention Unit (BCIU) began operations but not necessarily in the hills. These data came from SDPD BCIU.

30. Herman Goldstein. (1990). Problem-Oriented Policing. McGraw-Hill: New York, 152. Herman has been a great contributor to the development of problem-oriented policing in San Diego Police Department. This concept of working with other agencies to solve common problems, has been in place in San Diego for a number of years.

31. The South Levee is the flood control channel between the United States and México. This area was the most active for illegal crossing and border bandit activity.

32. A memorandum from Sergeant Joe Wood of the Border Crime Intervention Unit to Captain Jarvis, Commanding Officer of the Southern Division Operations, stated the current border violence along the South Levee.

33. The South Levee is the flood control channel between the United States and México. The flood channel is located along the San Ysidro/Tijuana international border.

34. SANDAG Report (1988). The Impact of Illegal Immigration on the Criminal Justice System. San Diego Association of Governments publication, July, 1989. SANDAG is comprised of members from most every city in San Diego county. 


\section{CHAPTER V \\ CONCLUSIONS/RECOMMENDATIONS}

This case study focused on the San Diego Police Department and its relationship along the Tijuana/San Diego international border from 1957 to 1994. An historical review of the San Diego/ Tijuana region was presented in order for the reader to better understand the dynamics of the San Diego/Tijuana border area.

Purpose of the Study

The purpose of this research was to investigate the circumstances which led to the establishment of the San Diego/ Tijuana international border (1846-1848) and the reasons why the border was created at its current location. In addition, the researcher examined the role of the San Diego Police Department along the international border from 1957 to 1994.

The research questions focused on the history of the international border at the San Ysidro Port of Entry and on the role of the San Diego Police Department along the border. This historical 
case study investigated the following:

- When and how was the United States/México international border established at the San Diego/Tijuana border region?

- What was the role of the San Diego Police Department at the international border from 1957 to 1994 ?

Significance of the Study

This study presented vital background data and information for decision makers and law enforcement community in the San Diego area. It also added to the body of literature regarding the San Diego/Tijuana border region for general research purposes and for the community at large. In addition, the study provided the San Diego Police Department with information on the history of the Department and on the dynamics of the San Ysidro/ Tijuana border region.

\section{Discussion}

The study revealed that following the Méxican-American War, the Treaty of Guadalupe Hidalgo was signed in 1848. The San Diego/ Tijuana international border was established along the Tijuana River Valley. The City of San Diego was incorporated in 1888. The San Diego Police Department was established on May 16, 1889. In 1957, 
the City of San Diego annexed the community of San Ysidro; which brought the City of San Diego to the international border.

From 1957 to 1976, the San Diego Police Department did not have a border team along the international border. The police department did staff a border check point at the port of entry for southbound traffic. This border check point was operational until 1975. In 1976, the San Diego Police Department created a special border task force with the United States Border Patrol in order to protect the international border from border bandits. This task force was suspended after two years because of the violent nature of the border. These officers were involved, at times, in controversial shootings with Méxican law enforcement officials who had crossed into the United States territory to commit crimes.

Again from 1978 to 1984 , a six year period, the San Diego Police Department did not field a border team. During this gap in border law enforcement, the number of border crimes increased. The leadership of the San Diego Police Department re-evaluated the need for police service in the hills along the international border and created the Border Crime Prevention Unit (BCPU). United States Border Patrol agents were teamed with San Diego Police officers and 
formed two border enforcement teams, Alpha and Beta teams. This law enforcement team disrupted the lucrative border bandit activity along the San Ysidro/Tijuana international border.

Members of BCPU were in full uniform and patrolled the same region that members of the BARF team once patrolled. BCPU, much like the BARF team, were involved in controversial officer-involved shootings. These officers were involved in a total of thirty-five shooting incidents along the border. Once again, the leadership of the San Diego Police Department suspended the border team's operations along the international border.

In 1984, the 6th Annual Border Crimes Conference was held at the Town and Country Convention Center in San Diego, California. Fifty law enforcement officials from the United States and México met for a workshop on Border Violence. As a result of this workshop, several recommendations were identified. Some of the recommendations of this group were: 1) The Tijuana Municipal Police Department will study the feasibility of putting together a task force similar to the San Diego Police Department's Border Crime Prevention Unit; 2) The San Diego Police Department will inquire with the Federal Communications Commission to determine the possibility of 
both (México and U.S.A.) law enforcement agencies sharing a radio frequency for joint operations; and 3) The San Diego Police Department will up-date maps of both sides of the border with section numbers and provide them to law enforcement agencies along the border. 1

At one point the relationships between the San Diego Police Department and the Tijuana Municipal Police Department were strained. In April 1985, the San Diego Border Crimes Task Force detained four Tijuana Police officers who entered the United States territory. Earlier in the week, Méxican State Judicial Police Commander Luis David Bolanos, told the San Diego Union that from now on San Diego Police who need help from their Méxican counterparts will have to make requests in writing to the Méxican Consulate. 2 A spokesperson for the San Diego Police Department, however, contended that Méxican officials were still cooperating with their liaison officers. 3

Tijuana Municipal Police officers suggested ways which the United States could reduce the violence along the border. One of the suggestions was for the United States to install massive lights near the canyons along the border to stop the undocumented alien flow 
and to protect those who make the journey north.t

In May, 1989, after four months of inactivity, the border team resumed operations along the border. On this occassion, the border team underwent some changes. The name of the team was changed to the Border Crime Intervention Unit (BCIU), San Diego Police Depart-ment's SWAT officers were added to the border team, and the U.S. Border Patrol's involvement was reduced to just one supervisory agent assigned as the liaison to the border enforcement team.

In 1990, México began a border task force from the south side of the border. This task force consisted of officials from the Méxican Customs and Immigration, Tijuana Municipal Police Department, and State Judicial Police Department. Soon after the creation of this task force, members from the BCIU began collaborating with members from the Méxican task force, which was named the Beta Group. Officers from both teams quickly developed a working relationship which fostered an unprecedented cooperation between officers from the United States and México.

In July 1990, Javier Valenzuela was the Beta Group's commander. Valenzuela was a university-trained psychologist who was new to law enforcement. Mr. Valenzuela stated in an interview 
with the San Diego Union, "we're going to be neighbors all of our lives, so we have to take care of the neighborhood."5

Under the direction of Mr. Valenzuela, the Beta Group evolved into an internationally acclaimed border task force which reduced violence along the San Diego/Tijuana international border, improved relationships with the United States and largely resisted the corruption which plagues Méxican law enforcement officials.

This unique collaboration and partnership was jeopardized when Javier Valenzuela, Commander of the Beta Group, was replaced by Mario Arturo Coutino, who was reported as saying, " It must be clear that the Beta is a Méxican force. It had reached a point where we were a complement of the agencies of our neighbors. We should develop a concrete agenda, demarcating clearly our functions."6 In December 1992, Mario Arturo Coutino, took over as "top-cop" in charge of the Beta Group replacing Javier Valenzuela, who served until November, 1992.7 Some observers worried about the future of the Beta Group following Valenzuela's departure. 8

The new Beta Group administration suspended the monthly joint training sessions and meetings with the Border Crime Intervention Unit, a San Diego Police tactical squad which had 
developed a close rapport with the Beta Group. According the Los Angeles Times, a San Diego Police official stated, "It's a safety issue. It creates an atmosphere for an incident that could lead to serious consequences." 9

In October 1993, Mr. Coutino was replaced by Hugo Ayala Morales. Mr. Ayala took over as the Beta Group's commander in November 1993 and served in that capacity until February 1995.10 In February 1995, Alejandro Olea Garcia was selected as Mr. Ayala's replacement. Mr. Olea became the fourth commander of the Méxican task force, the Beta Group. Since its founding, the Beta Group has been headed by federal civil servants from México's Immigration Office, usually men with academic backgrounds.11

The Beta Group's operation was unique because of the incredible amount of cooperation between México and the United States. This cooperation developed into a partnership between officers from the BCIU and the Beta Group. Officials from both agencies met and exchanged information on a daily basis, each law enforcement agency had the other's radio frequency; thus, these officers were able to communicate rapidly as events were unfolding along the international border, whether it was a border bandit 
fleeing south across the border into México or vice versa.12

In addition to the daily meetings that were held between officers from the BCIU and the Beta Group, each month BCIU and Beta Group officers held firearms training sessions. These training sessions were held on both sides of the border. A close bond had formed between officers from both teams. Consequently, this bonding resulted in mutual respect between the two groups. Key to this trust was the elite nature of the Beta Group officers. Although a concern among U.S. law enforcement agencies was the regrettable, but frequent corruption seen among some members of Méxican law enforcement agencies. In the case of the Beta Group, these officers were screened and selected with anti-corruption in mind. In addition, Beta Group officers were paid considerably more than their colleagues and corruption was not tolerated within the Beta ranks. Members of the BCIU team were impressed by the quality of the Beta Group officers and felt that corruption was non-existent within the Beta Group at that time. 13

As was evident during the 1950 s to 1980 s, there was little or no cooperation amongst law enforcement officials from México and the United States. During 1957, when the City of San Diego annexed 
the community of San Ysidro, bringing San Diego to the international border, the San Diego Police Department operated a juvenile check point at the port of entry, as people were traveling south into México. In 1975, the leadership of the San Diego Police Department decided that its officers could be best employed elsewhere and were removed from the border check point. This move brought an end to the juvenile check point at the international border.14

In 1976, a special border task force was created and it patrolled the canyons and hills along the international border. The task force was suspended two years later because the border bandit activities were extremely violent. The officers from the task force were involved in a number of shootings and were also involved in armed confrontations with officials from México. Later, in 1984, another special border task force team was introduced at the international border. This team was also involved in controversial shootings which resulted in the suspension of this task force.

The cooperation and the working relationships between law enforcement officials from México and the United States were strained during this period. It appeared that only the San Diego Police Department México liaison officers could get any form of 
cooperation from the Méxican officials. 15

During the 1990s, however, the leadership of the San Diego Police Department decided to once again re-introduce a border enforcement team along the international border, because of the high number of violent crimes which were reported along the border. This team was specially trained by members of the San Diego Police Department's SWAT/Special Response Team (SRT). In fact, members of the SRT team comprised the Border Crime Intervention Unit (BCIU). In addition, Méxican law enforcement agencies had established a border task force of their own, on the south side of the San Ysidro/Tijuana border.

The relationships between officers from the BCIU and the Beta Group were unprecedented. These officers communicated over their own radio frequency, they conducted training sessions together, and they held joint tactical operations along the border. As a result of this cooperation and partnership, the number of officer-involved shootings, along the border, decreased and so did the number of violent crimes.

The cooperation between these two law enforcement border task forces was outstanding. An example of this cooperation 
occurred during the floods of 1982 and 1993. In January 1993, residents along Monument Road, south of the Tijuana River Valley, were effectively trapped between México and the swollen Tijuana River. The San Diego Police Department received reports that residents in that area had armed themselves in order to protect themselves from looters. Negotiations with representatives from the Méxican Government were initiated to arrange for San Diego Police officers access to the isolated area of the Tijuana River Valley through roads in Tijuana, México. The first attempt to have United States law enforcement officials and Fire Department equipment escorted through Tijuana, México, to a point on the border where a section of the border fence could be cut, was thwarted. Negotiations continued with the Méxican Government for approximately 24 hours. Once approval had been obtained from the Méxican Government, San Diego City crews were able to cut a hole in the border fence from the Méxican side of the border. Two San Diego Police vehicles, three LifeGuards and a Fire Department Brush Company and vehicles drove through Tijuana, México, and onto Monument Road.16

This is just one example of the kind of humanitarian act and respect which each law enforcement agency had for each other. It 
did not matter that one agency was from the United States and the other from México. The cooperation and partnership that had been developed between these officers were put to the test during an emergency situation.

\section{Conclusions}

As the researcher has stated, in addition to the improved communications between officers from the BCIU and the Beta Group, the supervisors from both units met monthly to discuss future training needs, communications issues, and to critique past joint operations and to plan future tactical operations.

The daily contacts and monthly meetings which were held between BCIU and the Beta's command staff enabled BCIU to develop the excellent Bilateral International relationship it now shares with México. The meetings between both Units, were more than just meetings, the officers developed friendships and put those friendships to work in an effort to combat border violence.

The ability to work collectively between two different countries, cultures, and legal systems, in problem solving, required that each officer tactfully deal with these and other differences in a professional manner. Officers from both law enforcement agencies, 
BCIU and the Beta Group, were able to rreet these challenges and work joint operations along the international border for a common purpose--preventing violence. Implications for Leadership:

The dissertation revealed that a new leadership style was needed between officers from BCIU and the Beta Group. Officers from the United States and México developed relationships which allowed these officers to exchange information, develop partnerships, and create changes in law enforcement strategies in border crime prevention.

Herman Goldstein (1990) stated that a new leadership style would be important to the success of problem-oriented policing. 17 Goldstein suggested three changes: (1) Police leaders must articulate the basic values with which they approach the police task and which influence their management techniques; (2) they must have a strong commitment to problem solving as the core of policing; and (3) they must make fundamental changes in the most common type of relationship that exists between leadership and the rank-in-file of an organization. 18

Between 1990-1994, the leadership of the San Diego Police 
Department made it possible for the Border Crime Intervention Unit to work with the Beta Group. The leadership provided by the San Diego Police Department Chief of Police facilitated the training sessions and helped establish a working relationship with México's Beta Group.

According to Rost there is no universal definition of leadership, but most people think of leadership from a hierarchical, positivistic, and industrial paradigm perspective: that is, (1) leaders and followers resemble a hierarchical chain of command; (2) leaders announce the goals they have for the group or organization and followers automatically accept those goals and then set out to meet them; (3) leadership is primarily a one way communication; and (4) leaders have the right answers and thus lead the parade of followers. 19

Rost defined leadership as: "Leadership is an influence relationship among leaders and followers who intend real changes that reflect their mutual purposes" .20

Leadership happens when leaders and followers enter into the relationship that intends real changes. Leadership is about transformation. "Real transformation involves active people, 
engaging in influence relationships based on persuasion, intending real changes to happen, and insisting that those changes reflect their mutual purposes".21

James MacGregor Burns stated that transformational leadership occurs when, "one or more persons engage with others in such a way that leaders and followers raise one another to higher levels of motivation and morality.22 Burns went on to say, "Leadership is the reciprocal process of mobilizing, by persons with certain motives and values, various economic, political, and other resources, in a context of competition and conflict, in order to realize goals independently or mutually held by both leaders and followers. 23

The role and responsibility of the San Diego Police Department along the San Ysidro/Tijuana border from 1976 to 1994 showed that each border task force team had different relationships with their Méxican law enforcement counterparts. A relationship can be defined as an alliance, association, and connection. These terms, however, do not describe the reciprocity inherent in an influence relationship (Rost, 1991) nor the synergy experienced within that context (Guzmán, 1993).24

The border enforcement teams from 1976 to 1989 did not have 
a working relationship with officials from the México. Both of the law enforcement agencies, México and the United States, had their own agenda for reducing border violence. The violence along the border, however was at an all time high, during this period. No partnership or relationship existed between these officers.

As time went on, the relationship between BCIU and the Méxican law enforcement officials improved particularly between 1990 to 1994. The leadership of the San Diego Police Department provided for an influence relationship between, not only members of BCIU, but between officials from the Beta Group and BCIU. After a number of meetings between these officers, they were able to develop honest relationships which provided for open lines of communications. The purpose of each border team was to prevent border violence by reducing the number of homicides, rapes, and robberies that were occurring along the international border, from both sides of the border.

In a 1993 survey by Kouzes and Posner, more than 50\% of Americans surveyed rated honesty, forward-looking, inspiring, and competent as the most important qualities of the leaders they admired.25 These qualities were visible in the relationships between 
members of the Border Crime Intervention Unit and the Beta Group.

The honest, forward-looking, inspiring, and competence that Mr. Javier Valenzuela, the first commander of the Beta Group, brought to the Méxican law enforcement community, particularly to the Beta Group, brought Méxican law enforcement into the twentyfirst century.

BCIU's efforts in collaborating with the Beta Group, made crime prevention along the border a reality. With the Beta Group in place, officers from BCIU were able to deploy various tactics in order to intervene in the border bandit activities. Without the st pport of the Beta Group, however, the efforts of the BCIU enforcement team would have been fruitless.

\section{Recommendations}

It has been suggested that there is no one best design nor one perfect method of carrying out a piece of research. 26 The methodology used in this study, historical case study, appeared to have been particularly well suited for this dissertation.

A recommendation most frequently noted in doctoral dissertations is that of a follow up study. As a result of this research, the following recommendations are suggested for consideration: 
- To continue to provide educational/training programs and opportunities for law enforcement officials from both sides of the border with respect to mutual border concerns.

- To provide problem-solving and community policing strategies along the border region by officials from both sides of the border.

- To recruit additional Hispanic officers to fill positions on Bcrder Crime Intervention Unit (BCIU).

- To strengthen the San Diego Police Department's México Liaison Unit's relationship with the Méxican border task forces along the border region.

- To continue with the cooperation and partnership established between officers from the BCIU and the Beta Group.

- To increase the size of the United States Border Patrol and other Federal Government law enforcement agencies, in support of anti-narcotics smuggling along the United States and México border, with personnel and improved technological equipment.

- To simplify and expedite the legal process of returning undocumented criminal aliens to their country of origin. 
- To include the Méxican Government in the problem-solving strategies when narcotic smuggling and border violence prevention efforts are being discussed.

Although the United States Federal Government has the primary responsibility for the security of the United States borders; local and state governments can assist in this effort by preventing border violence and by forming partnerships with their colleagues from México.

The border violence that was reported in this dissertation occurred along a 14 mile stretch between the Pacific Ocean and the Otay Mountains. East of the Otay Mountains, is a mountain and desert region, which makes illegal crossing and narcotics smuggling difficult and control of these activities much more simplified. The effort to control or prevent border violence, illegal crossing, and narcotic smuggling, rests with local, state, and federal agencies.

The role and responsibility of the San Diego Police Department along the San Ysidro/Tijuana international border grew from 1957 to 1994. San Diego Police officers at first were conducting juvenile inspections at the border in 1957. In 1976, San Diego Police officers were involved in a special detail of patrolling the canyons and hills 
along the international border. These officers worked with agents of the U. S. Border Patrol as team members of the Border Alien Robbery Task Force (BARF). The working relationships between officers from the BARF team and the Méxican law enforcement officials were limited. On occasion, these officers were involved in officer-involved shootings between each other. As a result of these shootings, the BARF team was disbanded in 1978.

As time went-on, the border task force saw different opportunities and different challenges. During the 1980s, the border task force established a new form of policing the border. The border teams changed their old tactics of working as disguised Méxican aliens to working in full police uniform along the international border. In 1990, the border task force began working with the Méxican law enforcement Beta Group. Officers from both the United States and México developed professional working relationships with each other. The work accomplished by officers from the Border Crime Intervention Unit and officials from the Beta Group, as reported elsewhere, resulted in improved bi-lateral U. S./México relations and a reduction of crime along the border.

The crime prevention strategies which the Border Crime 
Intervention Unit, the United States Border Patrol and the Beta Group employed served the communities of San Diego and Tijuana, México, very well. As a result of the efforts by these law enforcement agencies, there were less officer-involved shootings and less violent crimes reported along the international border during the early 1990s.

The lives of many San Diego County residents, as well as their very way of life, will be in jeopardy unless something is done to reduce the violence along the border, and to control the increase of illicit drug smuggling through the San Diego/Tijuana border region. The recommendations made in this dissertation should not by any means be considered restrictive or racist. They are made here as an example of what officials from the United States and México Federal Governments, and state and local law enforcement agencies should consider in order to prevent border violence and reduce the violent nature of the border region. Citizens from San Diego, California and Tijuana Baja California, México share the same border region; the same air, water, pollution, and crime problems. Therefore, both countries need to work on solving their common problems in order to control the borders for future generations. 


\section{CHAPTER V \\ CONCLUSIONS AND RECOMMENDATIONS \\ ENDNOTES}

1. Sear Schmitt. The Informant. May, 1984. Border Violence workshop makes recommendations, p. 9.

Chairing the workshop were José Nuñez, Chief of Police, Tijuana Municipal Police; Manuel Guaderrama, Deputy Chief, San Diego Police Department; and Wayne Bailey, Captain, San Diego Sheriffs Department.

2. Joe Gandelman. The San Diego Union. April 28, 1985. A-14. "Relations between U. S., México police strained."

3. Ibid,

4. Ibid.

5. Ibid., E-3. Javier Valenzuela, although new to law enforcement, understood the problems facing the migrants and officers. He said their mission was not to help or hinder thousands of illegal border crossings taking place day and night along the border, a sensitive subject in México.

6. Ibid. The debate over the Beta Group's direction grew partly out of personality conflicts. The prior Beta commander, Valenzuela had developed strong loyalties and his successor had dismissed several of the Unit's founding members.

7. Mario Arturo Coutino, 40, previously worked in agrarian reform and indigenous affairs in the southern border state of Chiapas, México.

8. Sebastian Rotella reporter for the L. A. Times. Rotella has been following the Beta Group's developments from the beginning in 1990. Los Angeles Times, September 15, 1993, Part A, Page 3, Column 2.

9. Ibid.

10. Sebastian Rotella, staff writer for the Los Angeles Times reported that Hugo Miguel Ayala Morales worked as a Méxican Immigration Service official and was replaced by at the end of President Salinas' term.

11. San Diego Union. February 14, 1995, B-1 \& B-4. Alejandro Olea is a retired Méxican cavalry officer, considered an expert in military intelligence. As a sublieutenant, in the 19th, 8th, and 23rd cavalry regiments, Olea took part in operations against drug trafficking organizations in the states of Coahuila, Michoacan, and Sinaloa México. From 1978 to 1988, Olea was a member of the Estado Mayor Presidencial, an elite corps of plainclothes army officers charged with presidential protection, similar to the U.S. Secret Service. 
12. Jacobs, op. cit., "Borderline. ..," $115 \& 17$.

13. Ibid., 17.

14. Although the juvenile check point was closed in 1975 , today during the Spring break or other holidays, the San Diego Police Department staffs a special juvenile check point as people are crossing south into México on foot. There is no longer a vehicle check for minors entering México.

15. Joe Gandelman, staff writer, The San Diego Union. April 28, 1985.

"Relations between U. S. and México police strained." pp., A1, A 14-16.

16. San Diego Police Department Memorandum from Sergeant Chuck Peak to Captain David Bejarano, via Lieutenant Greg Fay. Dated January 21, 1993.

17. Problem-oriented policing (POP) is a comprehensive plan for improving policing in which the high priority attached to addressing community problems shapes the police agency. POP involves a problem-solving approach which includes: Scanning - identifying an issue and determining if it is a problem; Analysis - collecting information on the problem from all available sources; Response - using the information to develop and implement solutions to the problem; and Assessment - determining if the response to the problem was effective.

18. Herman Goldstein. (1990). Problem-Oriented Policing. McGraw-Hill: New York, 152. Herman has been a great contributor to the development of problem-oriented policing in San Diego Police Department. This concept of working with other agencies to solve common problems, has been in place in San Diego for a number of years.

19. Rost, J. (1991). Leadership for the twenty-first century. N.Y: Praeger.

20. Ibid.

21. Ibid., p. 123.

22. Burns, J. M. (1978). Leadership. New York: Harper and Row.

23. Ibid.

24. Nadyne Guzmán is an Assistant Professor and Director of Educational Leadership at the University of Colorado at Colorado Springs and president of Guzmán Creative Consulting Services.

25. James M. Kouzes \& Barry Z. Posner. (1993). Credibility: How leaders gain and lose it, why people demand it. San Francisco: Jossey-Bass.

26. Julian L. Simon. (1969). Basic Research Methods in Social Science. New York: Random House. 


\section{BIBLIOGRAPHY}

\section{$\underline{\text { BOOKS }}$}

Anderson, Gary. (1990). Fundamentals of Educational Research. New York: The Falmer Press.

Bancroft, Hubert H. History of California, 1542-1890. Vols. 18-24 in his Works. San Francisco: The History Company, 1884-1890.

Barzun, Jacques \& Graff, Henry F. (1992). The modern researcher. (5th ed.). New York, N. Y.: Houghton Mifflin.

Bean, F. D., \& Vernez, G., \& Keely, C. B. (1989). Opening and closing the doors: Evaluating immigration reform and control. Santa Monica, CA: Rand Corporation.

Bennis, W., \& Nanus, B. (1985). Leaders: The strategies for taking charge. New York, N. Y: Harper and Row.

Bolton, H. (1921). The Spanish Borderlands: A chronicle of Old Florida and the Southwest. New Haven: Yale University Press.

Brandes, Ray (ed. and translator). (1972). The Costansó Narrative of the Portolá Expedition: First chronicle of the Spanish Conquest of Alta California. Newhall, California: Hogarth Press.

Briggs, V. M., Jr., Fogel, W., \& Schmidt, F. H. (1977). The Chicano worker. Austin, TX: University of Texas Press.

Burns, James. M. (1978). Leadership. New York, N. Y.: Harper \& Row.

Camin, H. A., \& Meyer, L. (1993). In the shadow of the Mexican Revolution: Contemporary Mexican history, 1910-1989. Austin, TX: University of Texas Press.

Carte Gene E. and Carte Elaine H. (1975). Police Reform in the United States: The era of August Vollmer, 1905-1932. U.C. Berkeley. 
Castanien, Pliny. ((1993). To protect and serve: 1889-1989. San Diego Historical Society: San Diego, CA.

Cornelius, W. A., Chaviz, L. R., \& Castro, J. G. (1982). Mexican Imigrants and Southern California: A summary of current knowledge. Research report series, 36. Center for U.S. - Mexico studies. University of California at San Diego: San Diego, CA.

De Pree, M. (1989). Leadership is an art. New York: Dell.

Davidson, James W. and Lytle, Mark Hamilton. (1982). (2nd) After the fact: The art of historical detection. New York, New York: Alfred A. Knopf, Inc.

Engstrand, Iris. (1980). San Diego: Cornerstone of California. Continental Press Inc.: Oklahoma City.

Fernandez, Raul A. (1989). The Mexican-American border region: Issues and trends. Notre Dame, Indiana: University of Notre Dame Press.

Gilderhus, Mark T. (1987). History and Historians: A Historiographical Introduction. Englewood Cliffs, NJ: PrenticeHall.

Glesne, C., \& Peshkin, A. (1992). Becoming qualitative researchers: An introduction. White Plains, NY: Longman.

Goldstein, Herman. (1990). Problem-Oriented Policing. New York,New York: McGraw-Hill.

Gottschalk, Louis. (1950). Understanding history: A primer of historical method. New York: Knopf.

Guba, E. G. \& Lincoln, Y. (1981). Effective evaluation. San Francisco: Jossey Bass. 
Guba, E. G. \& Lincoln, Y. S. (1982). "Epistemological and methodological bases of natural inquiry," in Madaus, G. F., Scriven, M. S., \& Stufflebeam, D. L. (1982). Evaluation Models: Viewpoint on educational and human services evaluation. (pp. 311-333). Boston: Kluwer-Nijhoff.

Halleck, Henry. (1968). The Mexican War in Baja California. (Doyce Nunis, ed.). Los Angeles: Dawson's Books Shop.

Herzog, L. A. (1990). Where North meets South: Cities, space, and politics on the U. S.-Mexico border. Austin, TX: University of Texas Press.

Hensley, Herbert C. "The memoirs of Herbert C. Hensley," San Diego Historical Society--Serra Museum and Library, San Diego, California, Chapter 1, Vol. I, 7.

Higgins, L. (1961). Policewomen's Manual. Springfield. Il.: Charles Thomas Publisher.

Horne, Peter. (1980). Women in Law Enforcement. 2nd Ed. Springfield, Il:, Charles Thomas Publisher.

Hunt, D. D. (1994). California criminal law concepts. (9th ed.). Edina, MN: Burges.

Kennedy, P. (1993). Preparing for the twenty-first century. New York: Random House.

Knight, Alan. (1987). U. S. -Mexican relations, 1910-1940. Monograph Series, 28. University of California, San Diego.

Kouzes, J. M., \& Posner, B. Z. (1987). The leadership challenge. San Francisco: Jossey-Bass.

Lamm, R. \& Imhoff, G. (1985). The immigration time bomb-the fragmenting of America. New York, New York.: E. P. Dutton. 
Laszlo, E. (1993). "Dimensions of a new world order," in S. Moorcroft (Ed.), Visions for the 21st century (pp. 9-17). Westport, CT: Praeger.

Lightenberg, J. (1983). "Mexican migration and U. S. policy: A guide for the perplexed," in P. G. Brown \& H. Shave. (Eds.), The border that joints: Mexican migrants and U.S. responsibility. (pp. 13-27). Newark, NJ: Rowman and Littlefield.

Lincoln, Y. S., \& Guba, E. (1985). Naturalistic inquiry. Beverly Hills, CA.: Sage.

Lingenfelter, Richard E. (1967). The rush of '89. Los Angeles: Dawson's.

Lowenthal, A. F., \& Burgess, K. (eds.). (1993). The California Mexico connection. Stanford, CA: Stanford University Press.

MacPhail, E. C. (1969). The story of New San Diego and of its founder Alonzo E. Horton. San Diego,CA.: Pioneer Printing.

Marshall, C., \& Rossman, G. B. (1989). Designing qualitative research. Newbury Park, CA: Sage.

Martin, Susan. (1988). "Female Officers on the move? A status report on women in policing," in Dunham and Alpert.(ed.), Critical Issues in Policing. Grove Park, Ill.: Waveland Press.

Martinez, Oscar. J. (1994). Border people. Tucson, AZ: The University of Arizona Press.

Merrian, Sharan B. \& Simpson, Edwin L. (1984). A guide to Research for Educators and Trainers of Adults. Malabar, FL.: Robert E. Krieger Publishing Company.

McGrew, Clarence A. (1922). City of San Diego and San Diego County: The birthplace of California. Volume I, The American Historical Society: Chicago and New York. 115-116. 
McKeever, M. (1985). A short history of San Diego. S.F., CA.: Lexikos.

McPhail, Elizabeth C. (1979). The Story of New San Diego and of its Founder Alonzo E. Horton. 2nd Edition revised. National City: San Diego Historical Society.

Meier, M. S., \& Rivera, F. (1972). The Chicanos: A history of Mexican Americans. New York: Hill and Wang.

Morris, M. D. \& Mayio, A. (1982). Curbing illegal immigration: A staff paper. Washington, DC: The Brooking Institution.

Mouly, George. (1970). Educational Research. Boston: Allyn and Bacon, Inc.

Nickel, James W. (1983). "Human Rights and the rights of aliens," in Peter G. Brown \& Henry Shue, (eds.), The Border that joins: Mexican migrants and U. S. responsibility. Totowa, New Jersey: Roman and Littlefield.

Prassel, F. R. (1972). The western peace officer: A legacy of law and order. Norman, Ok: University of Oklahoma Press.

Proffitt, T. D. (1994). Tijuana: The history of a Mexican metropolis. San Diego, CA.: San Diego State University press.

Ramirez, A. (1992). “A review of the Lemon Grove incident," in J. Villarino, \& A. Ramirez. (Eds.), Chicano Border Culture and Folklore. (pp. 169-172). San Diego, CA: Marin.

Rico, C. (1993). “From State to 'state': Managing Mexico's California connection," in A. F. Lowenthal, \& K. Burgess. (Eds.), The California Mexico connection (pp. 239-253). Stanford, CA: Stanford University Press.

Rost, J. C. (1991). Leadership for the Twenty-First Century. New York: Praeger. 
Ruiz, R. E. (Ed.). (1963). The Mexican War: Was it manifest destiny? New York: Holt, Rinehart, and Winston.

Schurz, William L. (1959). The Manila Galleons. New York: E. P. Dutton.

Smythe, William E. (1908). History of San Diego1542-1908: An account of the rise and progress of the pioneer settlement on the Pacific coast of the United States. Vol. I. "Old Town." The History Company, San Diego: CA.

Spradley, J. P. (1979). The ethnographic interview. San Francisco: Holt, Rinehart, \& Winston.

Stake, Robert E. (1983). "The case study method in social inquiry," in George F. Madaus, Michael S. Scriven, and Daniel L (eds.), Evaluation models: View points on educational and human services evaluation. Stufflebeam. Norwell, MA.: Kluwer-Nijhoff.

Staley, Joseph. (1981). "Law enforcement and the border," in Erb, Richard D. \& Ross, Stanley R. (eds.). United States Relations with Mexico: Context and Content. Washington, D.C.: American Enterprise Institute.

Steffens, Henry J. and Dickerson, Mary Jane. (1987). Writer's Guide: History. Lexington, MA: D. C. Heath and Company.

Strauss, A., \& Corbin, J. (1990). Basics of qualitative research. Newbury Park, CA: Sage.

Truss, R. S. (1992). "The Alabama National Guard from 1900-1920." Unpublished doctoral dissertation, University of Alabama, Tuscaloosa.

Turner, Ethel Duffy. (1981). Revolution in Baja California: Ricardo Flores Magon's High Noon. Detroit, MI.: Blaine Ethridge.

Wambaugh, J. (1984). Lines and Shadows. : NY, NY.: Bantam Books 
Weber, D. J. (Ed.). (1973). Foreigners in their native land: Historical roots of the Mexican Americans. Albuquerque, NM: University of New Mexico Press.

Weber, D. J. (1982). The Mexican frontier, 1821-1846: The American Southwest under Mexico. Albuquerque, NM: University of New Mexico Press.

Weinberg, R. D. (1967). Eligibility for entry to the United States of America. Dobbs Ferry, NY: Oceana.

Williamson, John B., Karp, David A., Dalphin, John R., and Gray, Paul S. (1982). The research craft: An introduction to social research methods. Second Edition. 239-259. Boston, MA.: Little, Brown and company.

Winks, Robin W. (1968). (ed.). The Historian as Detective: Essays on Evidence. New York, NY: Harper and Row.

Wheatley, M. J. (1992). Leadership and the new science: Learning about organization from an orderly universe. San Francisco, CA: Berrett-Koehler.

Wolf, D. (1988). Undocumented aliens and crimes: The case of San Diego County. San Diego, CA: University of California at San Diego.

\section{NEWSPAPERS}

Chula Vista Star News - August 2, 1978, May 6, 1979.

Imperial Beach Reminder - August 2, 1978.

Imperial Beach Star News - August 23, 1987.

Los Angeles Times - November 12, 1987, February 19, 1989, March 10, 1992, September 15, 1993. 
San Diego Tribune - October 4, 1839; September 26, 1936; January 4, 1958; July 15, 1963; Feburary 4, 1971.

San Diego Union - January 26, 1871; August 25, 1891; March 15, 1942; January 19, 1916; January 20, 1916; December 5, 1917; August 10, 1951; February 10, 1958; November 24, 1963; May 29, 1964; April 7, 1974; July 11, 1975; July 24, 1981; April 28, 1985; December 11, 1991; May 18, 1993; October 30, 1993; January 22, 1994; October 1, 1994; Feburary 14, 1995.

San Diego Daily Sun - June 15, 1888.

San Diego Independent - August 28, 1955; August 28, 1987.

The Informant - November 1985; December 1985; September 1986; October 1986; December 1986; January 1987; October 1987; November 1987; December1987; March 1989; July 1989; July 1992; March 1993; June 1993; November 1993; June 1994.

Up Front - June 1984.

\section{ARTICLES AND MAGAZINES}

Bell, D.J. (1982). "Policewomen: Myths and reality." Journal of Police Science and Administration, 10 (1): 112-120.

Beta Group memorandum to Chief Bob Burgreen dated Feburary 29, 1992.

Brandes, Ray. (1974). Report on the Historical Research--Old Town, San Diego, California--the period 1821-1874. For the State of California Parks and Recreation Division, p. 350.

Brandes, Ray. (1976). "Mission San Diego de Alcalá: Archaeological and Historical Discoveries," in Some Catholic Reminiscences for the United States Bicentennial. Edited Msgr. Francis J. Weber, Catholic Conference of California by the Knights of Columbus. 
Brandes, R., Moriarty III, J. R., \& Carrico, S. (1985). History and Archaeology of New Town, San Diego, California. Published for Centre City Development Corporation, 1981 and 1985.

California Border Alliance Group, Southwest Border. Information collected from the United States Customs. Information came from a confidential report (May 15, 1995) on the threat assessment of the border region.

California Legislature, Joint Committee on Refugee Resettlement, International Migration and Cooperative Development. Joint Hearing on International Migration and Border Region Violence. June 22, 1990, At San Ysidro California.

California Assembly Select Committee on Statewide Immigration Impact. Grace Napolitano, Chairperson. "Summary Report Assembly Select Committee on Statewide Immigration Impact." Prepared by Assembly Office of Research, Jimmy R. Lewis, Director, Co-authors, Jennifer $\mathrm{Mu}$ and Brent Bamhart, May 1994. State of California, Assembly Publications Office, State Capitol, Box 942849, Sacramento, Ca. 94249-0001.

Cardenas, C. A. (1955). Tijuana, Ensayo Monigrafico. Editorial style, México, D.F.

Carter, G. F. Pleistocene man at San Diego. Johns Hopkins Press: Baltimore, MD.

Carrico, R. C. Archaeological Survey of proposed development Site at 1290-1298 Prospect Street, La Jolla. Report on file with the City of San Diego.

Carrico, S. H. “Urban Indians in San Diego: 1850-1880." Masters Thesis, University of San Diego, 1983.

City of San Diego, ordinance \#6311, section 6 and ordinance, \#5, section 20:20. 
Civil Service Commission Minutes - 1918, 54; 1919, 40; resolution \#23736, V 34:300;

Fallon, D. (1984). Battle at the Border.The National Centurion: A police lifestyle magazine, 2(7). 24, 36-37, 39, 54.

Hawkins, Steve L. (1986). A cat-mouse game gets bloody. U.S. News \& World Report. April 28, 1986, 30.

Hensley, Herbert. The Memoirs of Herbert Hensley:The History of San Diego, City, County, and region through the memories, anecdotes and recollections of Herbert Hensley. Collected and edited by Hensley over a three year period, 1949-1952. Vols. I-V. Deposited in the Archives of the San Diego Historical Society, October 6, 1952. Vol. IV. pp. 523-538.

International Boundary and Water Commission, United States and Mexico, Report revised October, 1990. Commissioner Narendra N. Gunaji, Secretary Manuel R. Ybarra; for Mexico, Commissioner Arturo Herrera Solis, Acting Secretary José de Jesus Luevano Grano. The Treaty of 1848 refers to the Treaty of Guadalupe Hidalgo of Peace, Friendship, Limits and Settlement between the United States and Mexico (TS 207; 9 Stat. 922; 18 Sta. (Pt. 2, Public Treaties) 492), and the Treaty of 1853 refers to the Treaty of December 30,1853, relating to the boundary line, transit of person, etc., across the Isthums of Tehuantepec (TS 208; 10 Stat. 1031; 18 Stat. (Pt. 2, Public Treaties) 503).

Junipero Serra, a Letter, “Two letters from the Old World," Pequod. University of San Diego, (Translated ) by Ray Brandes, Spring 1967, No. 2, pp. 25-36.

King, V. (1991). Rededicating ourselves to leadership and ethics in law enforcement. FBI Law Enforcement Bulletin, 60(1), 2426.

Le Bouef v. Ramsey, 26 FEP Case 884 (9-16-80). 
Lord, Lesli Kay. (1983). "A comparison of male and female peace officers' stereotypic perceptions of women and women peace officers." A non-published Doctor of Philosophy in Leadership and Human behavior Dissertation. United States International University. San Diego: CA.

Mathis, Michael W. Viscaino and Spanish Expansion in the Pacific Ocean. San Francisco: California Historical Society, 1968.

Martis, Kenneth C. (1970). "United States International Land Border crossing: San Ysidro, California." A Thesis for Master of Arts in Geography for San Diego State College, 19.

McClung, J. B. (1981). Texas Rangers along the Rio Grande: 19101919. Unpublished doctoral dissertation, Texas Christian University, Fort Worth.

Mendofik, P. J. (1994). Reflections on leadership. FBI Law Enforcement Bulletin, 63(8), 24-27.

Milton, Catherine. (1972). Women in Policing. Washington, D.C.: Police Foundation.

Moss, James T. (1987). San Diego DMZ: Police units patrol "adobe wall." Soldier of Fortune. July/87, 32-35.

Stuart, C.G. (1975). Changing status of women in police professions. Police Chief, XLII (4): 61.

Patton, Anne F. (1989). "Women Officers of the San Diego Police Department, 1912-1988." A Master of Arts Thesis submitted to the University of San Diego: CA.

Price, John A. A History of Tijuana: Border Town and Port-of-trade. October, 1968. A paper prepared for San Diego State University.

Ridgely, Roberta. The Man who built Tijuana. San Diego Magazine, Parts 1-10., March, 1966 - March, 1969. 
Rogers, Malcolm J. Ancient Hunters of the Far West. The Union Tribune Publishing Company (Ed.) with contributions by H. A. M. Worthington, E. L. Davis and C. W. Brock.

Rost, J. C. (1993). Leadership Development in the New Millennium. The Journal of Leadership Studies, 1, 102-103.

Russell, P. (1993). Policing San Diego's Southern Border. Law Enforcement Quarterly, August-October, 13-16.

San Diego Association of Governments (SANDAG). (1989). The impact of illegal immigration on the criminal justice system. San Diego, Ca: S. Panell.

San Diego Police Department Commemorative Album, 1889-1986. San Diego, CA.: San Diego Police Officer's Association.

San Diego Police memorandum, dated December 20, 1988, from Chief of Police Bob Burgreen outlining the concerns of the Southern Division officers.

San Diego Police memorandum, dated January 8, 1989, from acting Captain John Gregory to acting Commander Richard Toneck.

San Diego Police memorandum, dated January 10, 1989, from Captain Richard Toneck to Commander Dave Worden.

San Diego Police memorandum, dated April 24, 1990 from Lt. Dave Bejarano to captain Phil Jarvis.

San Diego Police memorandum, dated December 1, 1989 from Sergeant Joe Wood to Captain Phil Jarvis.

San Diego Police memorandum, dated December 19, 1990 from Sergeant Greg Sloan to Lieutenant Lee Vaughn.

San Diego Police memorandum, dated January 21, 1993 from Sergeant Peak to Captain David Bejarano. 
San Diego Police Department policy and procedure 6.18 dated January 15, 1994.

Shumway, G., Hubbs, C., and Moriarty, J. R. Scripps Estates Site, San Diego, California: A La Jolla Site dated 5460 to 7370 years Before the Present. Annuals of the New York Academy of Sciences, Vol. 93. Article 3, pp. 97-132.

Smith, B. F. \& Moriarty, J. R.. The Archaeological Excavations at Site $W-20$. Environmental Impact Report on file at the City of San Diego, Environmental Quality Division, and at Brian F. Smith and Associates.

Staats, Issac. (July,1987). Border legend: Casting a giant shadow on the San Diego Border. Soldier of Fortune,

The National Centurion: A police lifestyle magazine. Volume 2, number 7. Battle at the Border. August 1984.

Treaty of Guadalupe Hidalgo, Article V, as found in Peter Thomas Conmy, A Centennial Evaluation of the Treaty of Guadalupe Hidalgo, 1848-1948. Oakland: Public Library, 1948, p. 28.

United States Bureau of the Census. (1993). Hispanic Americans today (Current Population Report, P23-183). Washington, DC: Government Printing Office.

United States Department of Justice. (1978). Annual reports of the Immigration and Naturalization Service, 1978-1982. Washington, DC: Government Printing Office.

United States Office of the Census, Twelfth Census of the United States, 1900, Part I, Population. Washington, D. C. Government Printing Office, 1901, clxxiv; United States Office of the Census, Thirteenth Census of the United States, 1910, vol. 1, Population. Washington, D. C. Government Printing Office, 1913, 781; United States Office of the Census, Fourteenth Census of the United States, 1920, vol. 2, Population. Washington, D. C. Government 
Printing Office, 1922, 693; United States Office of the Census, Fifteenth Census of the United States, 1930, vol. 3, Population. Washington, D. C. Government Printing Office, 1933, 225.

US Magazine, December 31, 1984. "One square mile of hell." 28-31.

U. S. News and World Report, 58, May 31, 1965, 73-75.

Walker, Samuel, Professor of Criminal Justice, University of Nebraska at Omaha. Employment of Black and Hispanic Police Officers, 1983-1988: A follow-up study. Occasional paper: No. 89-1, February 1989. Center for Applied Urban Research, University of Nebraska at Omaha, Peter Kiewit Conference Center, 1313 Farnam-ori-the-Mall, Omaha, Nebraska, 68182.

Warren, C. N., and True, D. L. The San Diego Complex and Its place in California Prehistory. UCLA Archaeology Survey Report, pp. 246-388; J. R. Moriarty III, Transitional Desert Place in San Diego County, California. Science, Vol. 155, No. 3762, pp. 553556; and J. R. Moriarty, The Coast Diegueño, San Diego Historic Indians, Western Explorer I (3), pp. 9-21, San Diego: Cabrillo Historical Society.

White, Thelma, member of the Research Committee of the Historical Site Board of the City of San Diego, presented at a meeting of the Historical Site Board, July 10, 1970. Report on Agustin Haraszthy, first Sheriff of San Diego County.

\section{PHOTOGRAPH COLLECTION}

1 Horton Plaza, c1886. San Diego Historical Society.

2 William Smythe, San Diego Historical Society.

3 Tijuana tourist crossing Tijuana River, S.D. Historical Society.

4 Tijuana flood of 1927. San Diego Historical Society. 
5 View of Tijuana from border. San Diego Historical Society.

6 San Diego/Tijuana Border crossing, c1918, SD. Historical Society.

7 San Diego/Tijuana Border crossing, c1922, SD. Historical Society.

8 San Ysidro Port of Entry, c1925, San Diego Historical Society.

9 United States and Mexico border crossing, SD. Historical Society.

10 Cobblestone Jail, c1870. San Diego Historical Society.

11 Mexican Customs House, c1887. San Diego Historical Society.

12 San Ysidro/Tijuana border, c1969. San Diego Historical Society.

13 Chief of Police, Joseph Coyne. San Diego Historical Society.

14 SDPD officers in front of Station, San Diego Historical Society.

15 Antonio Gonzales, first Chief of Police, SD. Historical Society.

16 Officer Jerry Martindale, dispatching. SD. Historical Society.

17 Officer William Harrison in a "Radio" car,SD. Historical Society.

18 Southern Division, Border check, 1960s. SD. Historical Society.

19 Sam Edmonds, on motors. San Diego Historical Society.

20 First Hispanic officer, José Cota. San Diego Historical Society.

21 Policewomen candidates. San Diego Historical Society.

22 Connie Van Patten with other officers. SD. Historical Society.

23 Original Border team, BARF. Courtesy of Earnie Salgado.

24 Border Crime Prevention Unit, BCPU 
25 Border Crime Intervention Unit, courtesy of Alan Hayward.

26 BCIU logo

27 U.S. Border Patrol Agent Leo Calderhead. SD. Historical Society.

28 BCIU members talking with Mexican vendors, Carlos Medina.

29 Boundary marker at border, Carlos Medina.

30 Mexican nationals waiting to crossing into U.S., Carlos Medina.

31 High intensive stadium lights at border, Carlos Medina.

32 San Diego Police Department, c1938. SD. Historical Society.

\section{$\underline{\text { MAPS }}$}

Map of Horton's Addition, San Diego Historical Society.

Map of San Diego-Tijuana Border

Map showing second border crossing

\section{INTERVIEWS}

Collins, Ron. Retired SDPD Mexico liaison officer. Interviewed June 2, 1995, not taped recorded.

Crow, David. Retired SDPD Police Captain. Personal interviewed June 21, 1994, not taped recorded.

McGawn-Minto, Laura. Police Officer assigned to Eastern Division. Interviewed November 13, 1994. 
APPENDICES 
APPENDIX A

TERMINOLOGY

In this study, several terms were employed which may have broader significance. The following terms are defined as they applied to this investigation:

1. Baja California Norte refers to the peninsula of Baja California, that extends northward from parallel 28 to 32 degrees, 44 minutes, and which throughout history has been designated as Partido de la Frontera del Norte (1864-1888), Distrito Norte de la Baja California (1888-1931), Territorio Norte de la Baja California (1931-1952), and Estado de Baja California since 1952.1

2. Tijuana as a ranch, is the geographical location that was given in a land grant in 1829 to Santiago Argüello. Tijuana was considered a ranch up to the year 1899, when the Argüello family subdivided the ranch with the intent of establishing a town. In 1899, President Porfirio Diaz upheld the claim made by the Argüello family of the ranch called Tijuana.

3. Ciudad de Zaragoza: a name given to the town of Tijuana in the land grant deed, but the original name of Tijuana prevailed. 
4. San Ysidro. In 1908, William Ellsworth Smythe created a cooperative farming colony in the Tia Juana Valley. The land chosen by Smythe, comprised of three undeveloped ranches, costing $\$ 15,000$. Although a township had been laid out, very little improvements had been made in the area following the floods of 1891. This great flood also devastated the town of Tijuana, which was situated directly on the "line" in the river-bottom.

Smythe was able to attract people from all walks of life to the Little Landers Colony; teachers, professors, lawyers, doctors, preachers, artists, authors, bankers, mechanics, and a few farmers. The Little Lander's tract included 550 acres of which 150 lay in the flat area of the valley and the remaining 400 acres lay on the hillslopes above, where the main part of San ysidro is now. The building lots were $25^{\prime}$ by $140^{\prime}$ and sold for $\$ 250$; acre lots sold from $\$ 350$ to $\$ 550$ depending on the location.was a colony established by William Smythe in 1908. The Little Landers Colony was later named the town of San Ysidro after " the plowman Saint."2

5. Border Alien Robbery Task Force was best known as BARF. BARF was a team of San Diego Police officers that patrolled the 
border region along the Tijuana/San Ysidro border. These officers worked in undercover capacity and would disguise themselves as illegal aliens in order to apprehend border bandits. The Border Alien Robbery Force was created in 1976 but abolished two years.

6. Alien, as defined by the United States Immigration and Naturalization Service is a person who is not a citizen or a national of the United States. An alien must show either an Alien Registration Receipt Card (resident) or a Nonresident Alien Mexican Border Crossing Card (nonresident). A resident alien enjoys all of the rights of United States citizens, except the right to veto and the right to hold public office. A resident alien is required to pay taxes, may serve in the military forces, and most importantly, they may' obtain employment.

A nonresident alien, on the other hand, may only cross the border for a period of up to seventy-two hours within a twenty-five mile limit of the Mexican border. Although the nonresident alien crossing permit is easy to obtain, the holders of such cards are strictly forbidden to accept employment of any kind while in the United States. The purpose of this type of permit is to allow the holder the convenience of shopping and visiting relatives within the 
international frontier area of the United States. The researcher will use Alien and undocumented person interchangeably. 3

7. Border Crime Prevention Unit (BCPU) was a team of uniformed San Diego Police officers working with a team of U.S. Border Patrol agents along the San Ysidro/Tijuana border region. Five police officers and five Border Patrol agents were operating in a team concept. This team was created after the BARF team was disbanded in 1980.

8. Border Crime Intervention Unit (BCIU) is a special team of five San Diego police officers and a US Border Patrol supervisor working in a collaborative manner along the San Ysidro/Tijuana border region with the Mexican Grupo Beta.

9. Grupo Beta is a Mexican task force consisting of Mexican Immigration, Customs agents and Mexican Municipal police officers.

10. Operativo Beta will be used interchangeably with Grupo Beta. It is the same team of Mexican officials working along the Mexico/California border area. 


\section{APPENDIX B}

San Diego Police Department's Chief of Police 1889-1994

1. Coyne, Joseph From To

2. Crawford, William $\mathrm{H}$

05-16-89

05-26-91

3. Pringle, W. H.

$05-27-91$

$07-27-91$

4. Brenning, Jacob

$07-28-91$

$08-27-91$

5. Russell, James

08-28-91

05-09-97

6. Bushyhead, Edward W.05-05-99

05-04-99

7. Thomas, Albert A.

06-01-03

05-31-03

8. Moulton, George W.

06-17-07

06-16-07

9. Neely, William T.

09-04-07

09-03-07

10. Wilson, Jefferson "Keno" 5-03-09

04-30-09

11. Steer, Joseph E.

01-11-17

01-10-17

Patrick, J. (acting)

$05-05-17$

12. McMullen, Steward

10-10-17

05-04-17

10-09-17

13. Patrick, James

04-09-19

04-08-19

14. Doran, Joseph W.

06-01-27

$05-31-27$

15. Hill, Arthur R.

05-13-29

$05-12-29$

16. Benbrough, P.J.

05-04-31

05-03-31

17. Scott, Harry H.

08-26-31

08-03-31

18. Peterson, John T.

$06-12-32$

06-11-32

19. Newsom, Robert P.

08-01-32

07-31-32

06-04-33

20. Raymond, Harry J.

06-05-33

09-01-33

21. Peterson, John T.

$09-02-33$

09-06-34

22. Sears, George M.

09-07-34

04-27-39

Kelly, Harry (acting) 04-28-39

07-18-39

23. Peterson, John T.

07-19-39

03-20-40

24. Peterson, Clifford E.

03-21-40

10-15-47

01-07-62

26. Sharp, Wesley S.

10-16-47

01-03-68

27. Roed, Olif "Jimmy"

01-08-62

03-11-71

28. Hoobler, Ray L.

$01-04-68$

09-09-75

Kolender, W. (acting) 09-10-75

02-13-76

$07-29-88$

09-18-88

Burgreen, R.W.(acting) 07-30-88

01-01-93

30. Burgreen, Robert

$09-19-88$

31. Sanders, Jerry

05-17-93

present 


\section{APPENDIX C CODE OF ETHICS}

This document was originated by San Diego Police officers and has been adopted by many law enforcement agencies in California and throughout the United States:

As a law enforcement officer, my fundamental duty is to serve mankind; to safeguard lives and property; to protect the innocent against deception, the weak against oppression or intimidation, and the peaceful against violence or disorder; and to respect the constitutional rights of all men to liberty, equality and justice.

I will keep my private life unsullied as an example to all; maintain courageous calm in the face of danger, scorn, or ridicule; develop self-restraint; and be constantly mindful of the welfare of others. Honest in thought and deed in both my personal and official life, I will be exemplary in obeying the laws of the land and the regulations of my department. Whatever I see or hear of a confidential nature or that is confided to me in my official capacity will be kept ever secret unless revelation is necessary in the performance of my duty.

I will never act officiously or permit personal feelings, prejudices, animosities or friendships to influence my decisions. With no compromise for crime and with relentless prosecution of criminals, I will enforce the law courteously and appropriately without fear or favor, malice or ill will, never employing unnecessary force or violence and never accepting gratuities.

I recognize the badge of my office as a symbol of public faith, and I accept it as a public trust to be held so long as I am true to the ethics of the police service. I will constantly strive to achieve these objectives and ideals, dedicating myself before God to my chosen profession, law enforcement. 
APPENDIX D

MAP OF SOUTHERN DIVISION 710s and 720s

City of San Diego Lieutenant Areas 


\section{CITY OF SAN DIEGO \\ Lieutenant Areas}

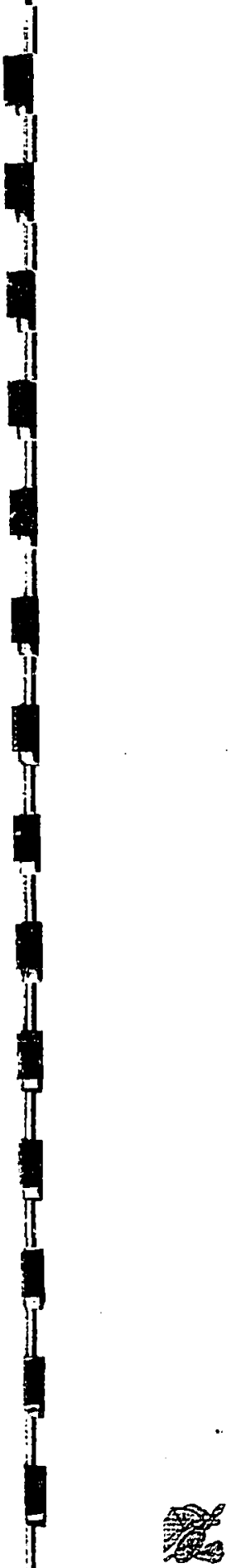

San Drego Pollo Dept.

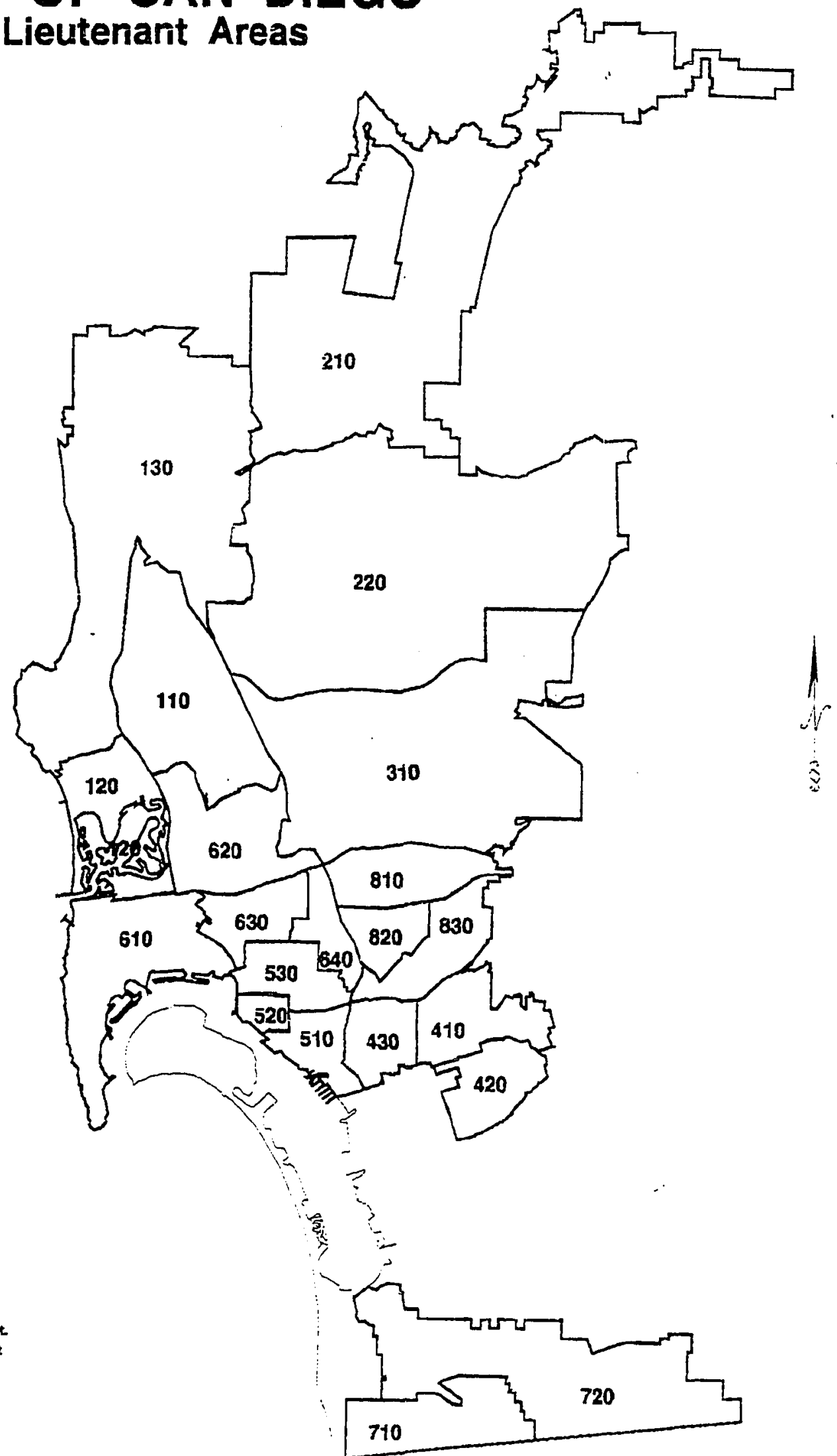




\section{APPENDIX E \\ CHRONOLOGICAL DEVELOPMENT OF \\ THE BORDER TASK FORCE TEAMS \\ 1977-1994}

1977 Lieutenant Bill Synder is assigned to head the newly created border task force team. Bill selects Sergeant Manny Lopes as the person to run the team. The team works with members of the united States Border Patrol. The team is named the Border Alien Robbery Task Force (BARF).

1979 The Border Alien Task Force is disbanded because of a number of controversial officer-involved shootings.

1984 A new border team is created. This team operated in full uniform and the officers wore their police badges (cloth). Five U. S. Border Patrol agents were assigned to the team. Two teams were created from these ten officers/agents. The Border Patrol supervisor and the San Diego Police Department supervisor each took a team-thus establishing an "Alpha" and a "Beta" team. These officers work jointly and in mixed groups. This team was called the "Border Crime Prevention Unit" (BCPU).

1986 The Border Crime Prevention Unit was pulled from the hills because of the high number of officer-involved shootings.

1988 The Border Crime Prevention Unit was brought back to work but with a number of restrictions. The team was not allowed to work the hills without prior approval from the field lieutenant or upon an emergency request from Border Patrol. 
Chronological Development of the Border Task Force Teams

1977-1994

(Continue)

1990 The border task force underwent several changes. The namde was changed to the ""Border Crime Intervention Unit" (BCIU) and only a U. S. Border Patrol supervisor was assigned to the team, as a liaison between San Diego Police Department and the United States Border Patrol. The BCIU also obtained a team of SWAT Special Response Team (SRT) officers to work on a four month rotating basis. This scheduled allowed for seven days a week coverage along the border.

Mexico began a border task force on the Mexican side of the border. The Mexican immigration and Mexican customs teamed up with municipal, state, and federal agents to form the Beta Group-Operativo Beta. The Beta Group worked closely with members of the Border CRime Intervention Unit. Both teams trained together and conducted joint field operations on both sides of the border.

1992 The Border Crime Intervention Unit loss the assistance of the SRT members. The SRT officers were pulled back to Headquarters. The remaining BCIU officers worked four days a week. BCIU still had the U. S. Border Patrol supervisor assigned to the team.

1994 The United States Border Patrol starts a new campaign to close the flow of undocumented persons, Operation Gatekeeper. The vast majority of criminal activity was pushed east from the San Ysidro Port of Entry. BCIU, however, continued to operate in the hills and canyons as usual. 


\section{APPENDIX F \\ Letter from Mexican Government.}

A letter from the Mexican government, Secretaria de Gobernacion, dated February 29, 1992, to Chief Bob Burgreen, San Diego Police Department, authorizing the use of the Mexican radio frequency for join operations. A copy as sent to this researcher, Adolfo Gonzales, Lieutenant in charge of the BCIU. 


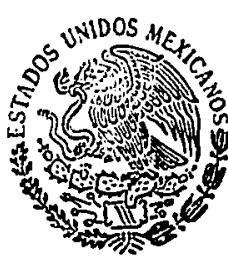

SECRETARIA

DE

GOBERNACION
DIRECCION GENERAL DE DEPENDENFHA, VTCTOS MIGRATORTOS

OPERATIVO ESPECTAL "BETA"

SECCION

MESA

EXPEDIENTE

\section{ASUNTO: EL OUE SE INDTCA}

TIJUANA, S. C., A 29 DE FEBRERO DE 1992.

AR. BOE BURGREEN

CHIEF. OF POLICE

SAN DIEGO POLICE DEPARTHENT.

$P R E S E N T E$.

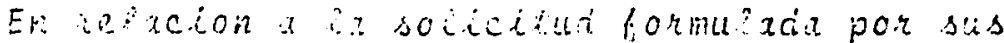

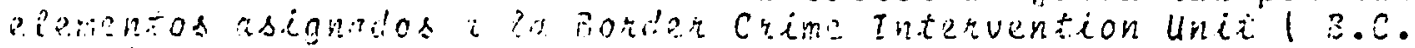

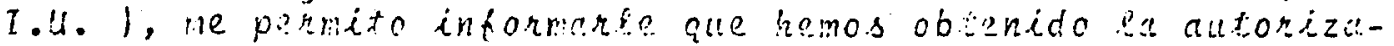

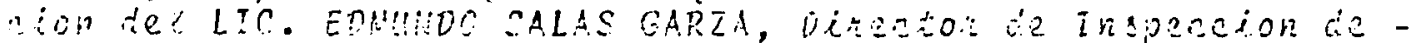

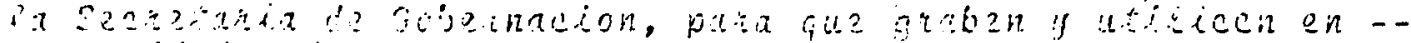

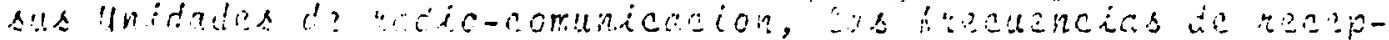

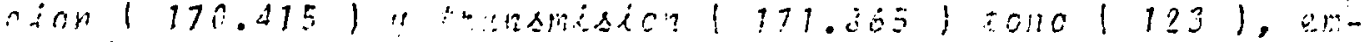

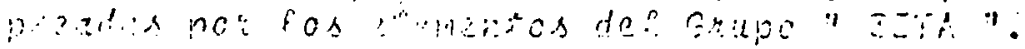

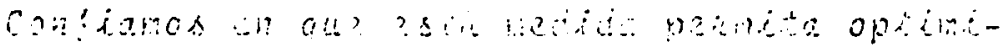

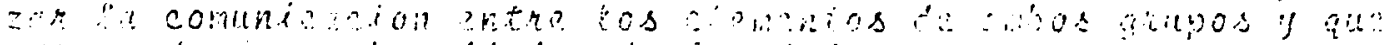

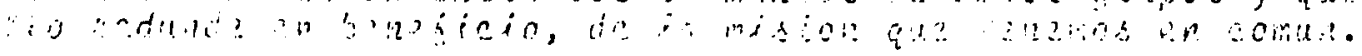

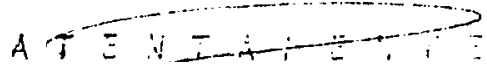

C. LIC. IRVIE? VILE!Z!E!: ULAGQ⿻ IELEC:DC

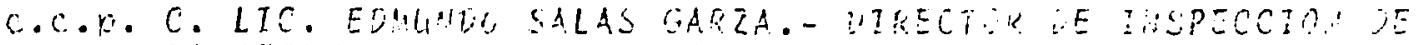

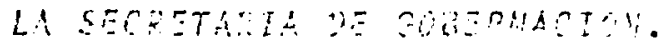

c.c.p. LT. ALULFO GOMZALEZ; SOUTHERU DIUTSICH, SAM DTEGO POLLCE TEPARTIHENT.

C.C.P. ARCHTVO

CITESE EL NUM. DEL EXPEDIENTE AL CONTESTAR ESTE OFICIO 


\section{APPENDIX G}

Radio Station license.

Radio Station License application from SDPD to the Federal Communications Commission (FCC), dated June 2, 1992 and expires June 2, 1997. With this improved communications, members from BCIU and Beta Group were able to work joint operations and safely apprehend suspects fleeing north or south of the border. 
License Name: SAN DIEGO, CITY OE

Radio Service: PR POLICE

Call Sign: WNZM235

Frequency Advisory No:

Number of Mobiles by Category: Vehicular - *
File Number: $\quad 9203261028$

Licensa Issue Dote: 920602

License Expiration Date: 970602

SAN DIEGO, CITY OF

$920602 \mathrm{~N} \quad 760 \quad 1 \quad 12$

1220 CAMINITO CENTRO

SAN DIEGO CA 92102

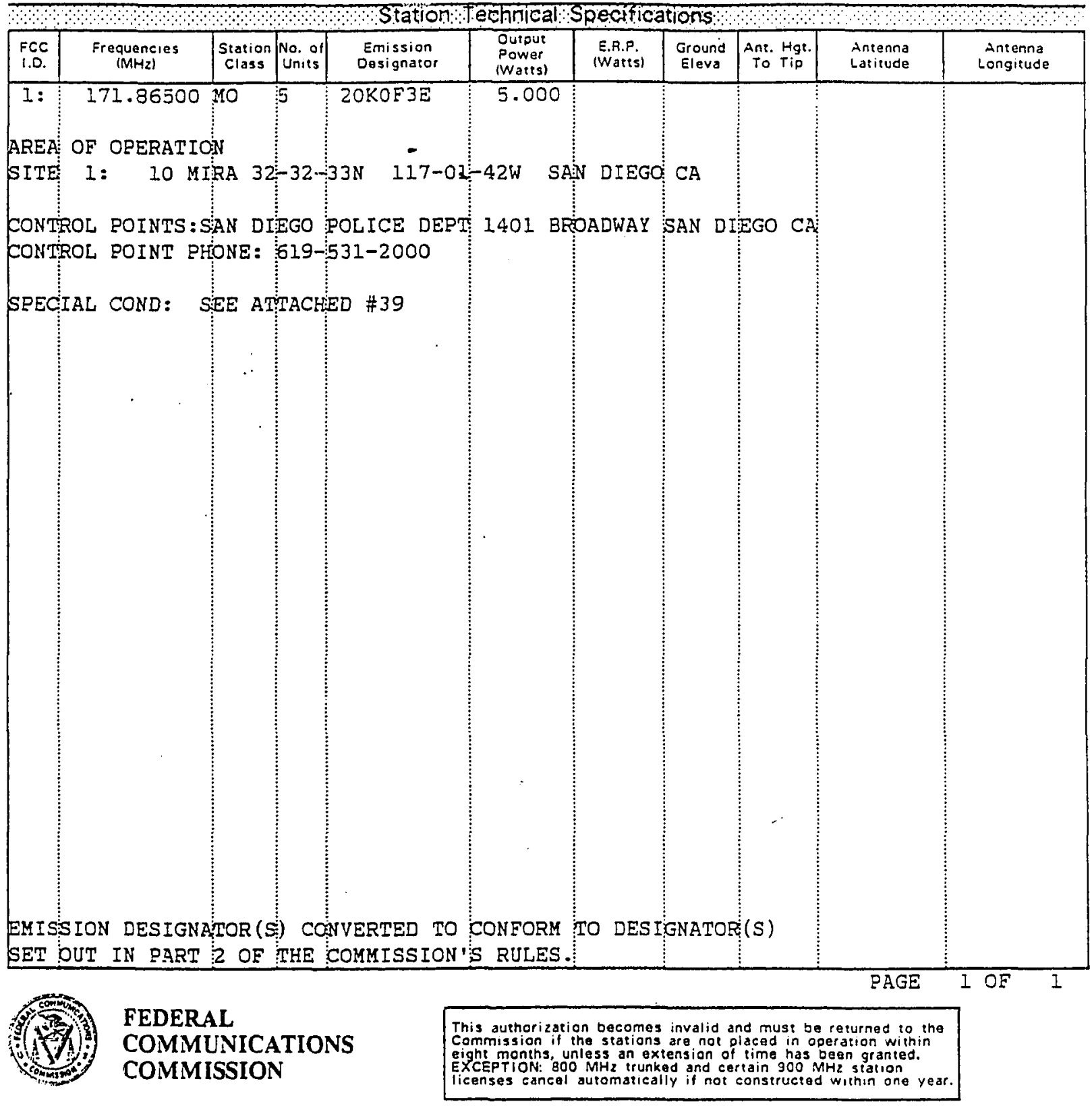




\section{APPENDIX $\mathrm{H}$}

National Guard letter, March 24, 1994 
Honorable Grace $F$. Napolitano

Member of the Assembly

State Capitol, Room 6011

Sacramento, California 95814

Dear MS. Napolitano:

This letter is in response to your recent inguiry regarding the possibility of using the National Guard to patrol the border. I have addressed your questions to the best of my ability without knowing exactly what the potential missions of the Guard would be. Your questions have been answered in the order asked.

- if the california national gunRd here assigned border patrol DUTIES TOMORRON, WOULD THE GUARD BE READY TO ASSUME THOSE BUTIES IMMEDIATELY?

- Ho. We are state troops and performing such a mission would likely require a change of statutes. Existing law and other constraints significantly limit the type of duty which could be performed. At present, any California National Guard support to the INS or border patrol would have to be 1 imited to a support role. There could be legal concerns regarding the use of armed military troops on the border and possibly viclating existing treaties (e.g. the Treaty of Guadalupe Hidalgo).

- are guard personiel trained in patrolling borders?

- llo. The llational Guard is trained in patrolling procedures. There is no military training in immigration operations and border patrol techniques in that special field.

- would guARd personNel come under the command or direction of bORDER PATROL OFFICIALS, OR WOULD THEY REMA.IN UNDER STATE COMMAND?

- The National Guard works in support of law enforcement, whether federal or state, but maintains command and control of its own forces under the governor. 
- WHat UNITS WOULD YOU COMxT?

- A special task force has been created to support law enforcement. The task force is comprised of individuals from all units of the California Army and Air National Guard and is trained and tailored to respond to law enforcement requests based upon the skills required.

- total personNei?

- Cannot be determined until we know the mission.

- WHAT MLJOR EQUIPKIENT (FOR EXAMIPIE, HEIICOPTERS)?

- Law enforcement agencies usually request the following equipment from the California National Guard: Helicopters, engineer equipment, radar, and electronic communications equipment.

- WHAT BASES WOULD THESE PORCES OPERATE OUT OF?

- National Guard and Active Component facilities near the border.

- hOULD GUARD PERSONNEL BE ISSUED LIVE AMMUNITION?

- Depends on the type of mission and potential risks involved. weapons are reserved for self-defense contingencies only.

- MHAT mEAPONS?

- Personal weapons such as M-16 Iifles, 45 caliber and $9 \mathrm{~mm}$ pistols.

- BECAUSE THIS IS A RATHER UNIQUE MISSION, AND OUTSIDE THE SCOPE OF ITS NORMAL PEACETIME ASSIGNLENTS, AND BECAOSE THE GUARD RELIES ON CITIZEN-SOLDIERS WHO DEDICATE ONE WEEKEND EACH HONTH AND TWO WEERS EACH YEAR TO MILITARY SERVICE, HOW WOULD YOU HANDLE PERSONNEI CAIL-UPS?

- Current regulations do not permit Guard personsel who are performing normal periods of Inactive Duty Training (weekend drill) or Annual Training (AT) from performing unrelated duty such as border patrol during these periods. Border patrol duty is not emergency duty contemplated under california Military and Veterans Code (MNV) sections 143 and 146 and would have to be performed pursuant to arve section 142, which does not confer police officer status. Normally, our 
procedure would be to seek and obtain volunteers in the numbers required or order persons to state Active Duty (involuntarily for short periods).

- WOULD THE SOLDIERS BE COMMITTED TO SERVE ONLY IN TWO-WEER INCREMIENTS OR EXTENDED ACTIVE DUTY?

- They would be volunteers not in federal status. Federal status would most likely violate the Posse comitatus Act. The National Guard is not a full-time organization. If a mission lasts longer than two weeks, we would most likely rotate volunteers in two week increments.

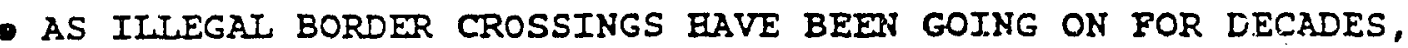
WOILD THE GUARD BE IN A POSITION TO MOUNT OPERATIONS INDEFINITELY?

- Probably not. It is questionable that this would be a continuing National Guard mission, since we are state troops and a Reserve Component.

- IF NOT FOR AN INDEPINITE TINE, FOR WHAT PERIOD OF TIME COULD THE GUARD MOUNT OPERATIONS WITHIN YOUR EXISTING BUDGET?

- within our current state budget, not at all.

- WITH EXISTING. STAFFING AND EQUIPMENT?

- Again, the mission and scope of operations must be defined.

- WHAT WOULD THE COST BE OF MOURTING OPERATIONS ON A WEERLY, MONTHLY, OR ANNUAI BASIS AND COULD THE GUARD ABSORB THOSE COSTS WITHIN ITS EXISTING BUDGET?

- Until we know the mission, we cannot determine the cost. In any case, funding would have to be appropriated to support additional requirements.

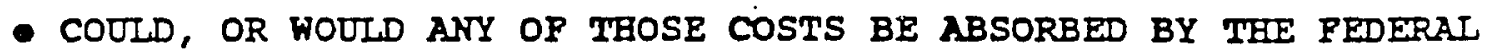
GOVERNMENT?

- Only if the Federal Government directed the mission, and forces were activated in a federal status.

- IF yOUR ANSHER TO QUESTION 1.' Is "No," whLT WOULD IT ENTAIL FOR THE GUARD TO BE "MISSION RRADY" IN TERHS OF TIME, TRAINING, STAFFING AND FUNDING?

- If properly resourced, we are mission ready for most of what we anticipate would be required. Again, there is a question 
of legality. We are constrained from participating in any kind of law enforcement activity regarding illegal immigration.

- HOW WOULD ASSUMING BORDER PATROL DUTIES INPACT THE GUARD'S ABILITY TO PERFORM ITS OTHER PEACETINE DUTIES?

- It would impact other responsibilities to some degree. The extent that peacetime duties will be affected can only be determined when the mission is known.

- WHAT ADDITIONAI AUTHORIZATIONS, IF ANY, WOULD THE GUARD NEED FROM EITHER THE STATE OR FEDERAI GOVERNMENT IN ORDER TO' APPREHEND, PURSUE, AND DETAIN PERSONS CROSSING THE BORDER ILLEGAILY FROM MEXICO INTO CALIFORNIA?

- The California National Guard is not currently permitted or trained to pursue, apprehend or detain persons in the manner contemplated by this question. In order to do so in a nonemergency situation on state duty requires a change in the law and extensive training. To provide support services requires less. The California National Guard cannot perform arrests in support of law enforcement in a purely federal status under Title 10, USC berause of the constraints of Posse comitatus.

- WOULD YOU BE AVAILABLE TO GIVE TESTIMONY BEFORE THE ASSEMBLY SEIECT COMMITTEE ON THIS SUBJECT WITHIN THE NEXT TWO-THREE WEERS?

- A representative from the Military Department can be made available to testify at the convenience of the select comittee.

Thank you for your inquiry. If you have any further questions regarding this or any other matter concerning the California National Guard, please have a member of your staff contact me at his or her convenience.

$$
\text { sincerely, }
$$

TANDY K. BOZEMAN

Major General

The Adjutant General 